\title{
Análise das contribuições dos Objetos Educacionais Digitais para a construção do conhecimento em Matemática na Educação Básica
}

Mateus Coqueiro Daniel de Souza

\author{
DISSERTAÇÃO APRESENTADA \\ AO \\ INSTITUTO DE MATEMÁTICA E ESTATÍSTICA \\ DA \\ UNIVERSIDADE DE SÃO PAULO \\ PARA \\ OBTENÇÃO DO TÍTULO \\ $D E$ \\ MESTRE EM CIÊNCIAS \\ Programa: Mestrado Profissional em Ensino de \\ Matemática \\ Orientadora: Professora Drª . Maria Cristina Bonomi
}




\section{Análise das contribuições dos Objetos Educacionais Digitais para a construção do conhecimento em Matemática na Educação Básica}

Esta versão da dissertação contém as correções e alterações sugeridas pela comissão julgadora durante a defesa da versão original do trabalho, realizada em 25/05/2016.Uma cópia da versão original está disponível no Instituto de Matemática e Estatística da Universidade de São Paulo.

Comissão Julgadora:

- Professora Drá. Maria Cristina Bonomi (orientadora) - IME - USP

- Professor Dr. Nílson José Machado - FE - USP

- Professora Dra . Ana Paula Jahn - IME - USP 


\section{Agradecimentos}

À minha mãe, Manoela, que me criou com amor e me incentivou durante toda a minha vida escolar.

Ao meu pai, Adalto, por arriscar sua vida, todos os dias, sobre duas rodas, para me dar condições de estudar.

À minha amada esposa Marília - companheira e conselheira - que sempre esteve presente me oferecendo seu ombro amigo.

À professora Dra. Maria Cristina Bonomi, orientadora, pela dedicação e pelo aprendizado.

À professora Maria José por ter apostado em mim e ter me dado condições para ingressar no Ensino Superior.

Aos professores Dra. Ana Paula Jahn e Dr. Nílson José Machado pelas valiosas sugestões e por terem aceitado participar da banca de defesa.

Aos professores do Programa de Mestrado Profissional em Ensino de Matemática do IME - USP, pelas contribuições ao longo de todo o curso.

Às editoras nas quais trabalhei, pelo conhecimento acumulado e aprimoramento profissional. 


\section{Resumo}

SOUZA, M.C.D. Análise das contribuições dos Objetos Educacionais Digitais para a construção do conhecimento em Matemática na Educação Básica. 2016.

135 f. Dissertação (Mestrado) - Instituto de Matemática e Estatística, Universidade de São Paulo, São Paulo, 2016.

Este trabalho tem por objetivo analisar de que forma os Objetos Educacionais Digitais (OED) - recursos recentemente integrados a algumas coleções de livros didáticos adquiridas pelo Ministério da Educação - podem contribuir para a construção do conhecimento em Matemática. Para tanto, foi estabelecido um referencial teórico constituído por autores que conceberam teorias e desenvolveram pesquisas visando a construção do conhecimento em Matemática. Esses autores se entrelaçam, se relacionam e se complementam. Com base em tal referencial, foram estabelecidos os critérios para a análise. O primeiro diz respeito à relação aluno - OED - tarefa, e está relacionado ao modo como o OED contribui para que as capacidades cognitivas dos alunos sejam mobilizadas e eles construam o conhecimento. O segundo, baseado na Teoria dos Registros de Representação Semiótica, está associado ao modo como os OED trabalham as diferentes representações de um mesmo objeto matemático. Por fim, o terceiro critério foca em como o contexto utilizado no OED possibilita ao aluno estabelecer relações entre diferentes conceitos da Matemática ou mesmo de outras áreas do conhecimento. Os resultados mostraram, dentre outras coisas, que os OED lidam com dois ou mais registros de representação diferentes, porém sem levar os alunos a coordená-los e que, na maioria deles, estão presentes situações que permitem aos alunos atribuir significados aos conteúdos matemáticos.

Palavras-chave: Objetos Educacionais Digitais, Livro Didático de Matemática, Informática, Ensino de Matemática, Registros de Representação Semiótica, Contextualização, Interdisciplinaridade. 


\section{Abstract}

SOUZA, M.C.D. Analysis of the contributions of the Digital Educational Objects for the construction of knowledge in Mathematics in Basic Education. 2016. 135

f. Dissertação (Mestrado) - Instituto de Matemática e Estatística, Universidade de São Paulo, São Paulo, 2016.

This study aims to examine how the Digital Educational Objects (OED) - newly integrated features to some collections of textbooks acquired by the Ministry of Education - can contribute to the construction of knowledge in mathematics. Therefore, it was established a theoretical framework consisted of authors who conceived theories and research developed to aim the construction of knowledge in mathematics. These authors intertwine, are closely relate and complement each other. Based on this framework, the criteria for analysis were established. The first, concerns the relationship student - OED - task, and is related to how the OED contributes to the cognitive abilities of students are mobilized and they build knowledge. The second, based on the Theory of Semiotics Representation Registers, is associated with how the OED work the different representations of the same mathematical object. Finally, the third criteria, focuses on how the context used in the OED enables students to establish relationships between different concepts of mathematics or even other areas of knowledge. The results showed, among other things, that the OED deal with two or more registers of different representations, but without having students to coordinate them, and in most of them, there are situations that allow students to assign meanings to the mathematical contents.

Key words: Digital Educational Objects, Textbook of Mathematics, Computer Science, Mathematics Teaching, Representation Registers Semiotics, Context, interdisciplinarity. 


\section{Sumário}

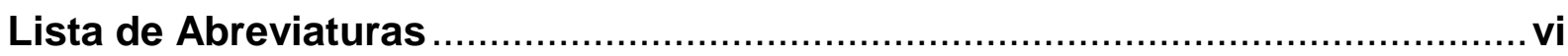

Lista de Figuras ........................................................................................... vii

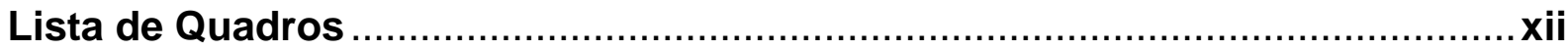

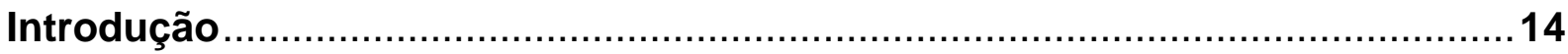

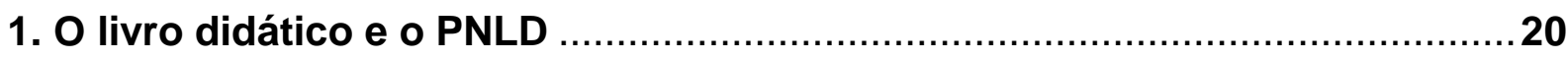

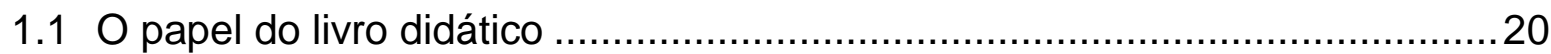

1.2 As políticas do livro didático no Brasil: das origens à consolidação do PNLD 26

2. O papel dos recursos tecnológicos no processo de ensino e aprendizagem de Matemática 31

2.1 Informática e Educação: pontos e contrapontos ………………………......... 35

2.2 O papel do computador no processo de ensino e aprendizagem ...................38

2.2.1 A perspectiva de Tikhomirov .......................................................... 39

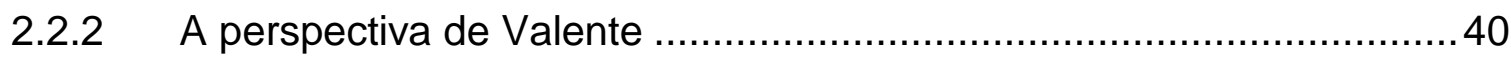

3. Na busca da construção de um conhecimento matemático significativo......54

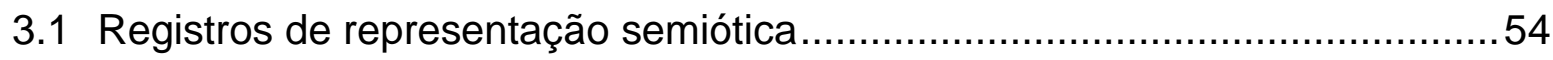

3.2 Interdisciplinaridade e contextualização ......................................................61

4. A pesquisa propriamente dita: os Objetos Educacionais Digitais presentes

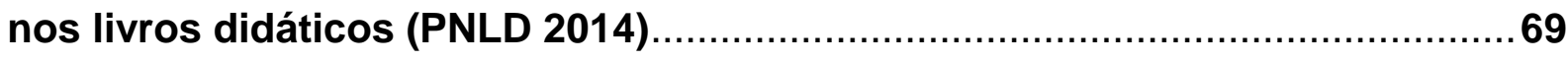

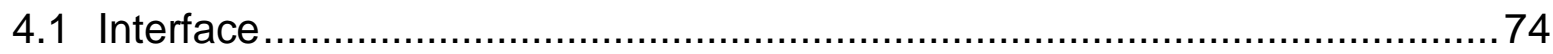

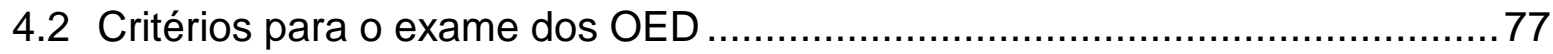

4.2.1 Critério 1: Relação aluno - OED - tarefa ………………………........77

4.2.2 Critério 2: Mobilização de diferentes registros de representação..........79 


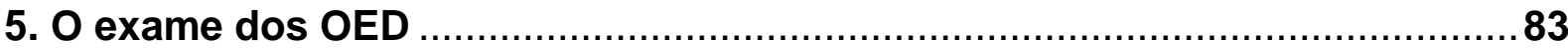

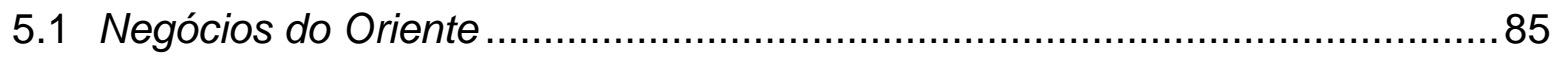

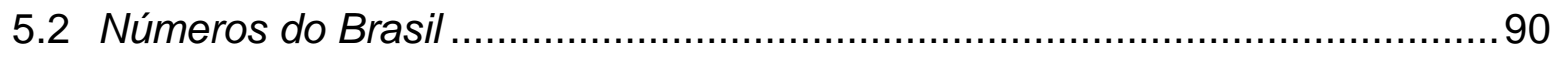

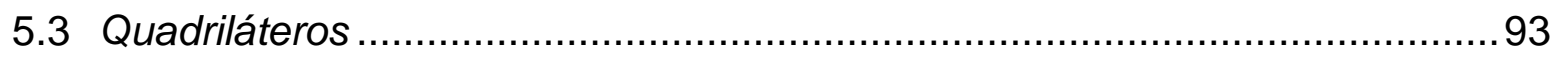

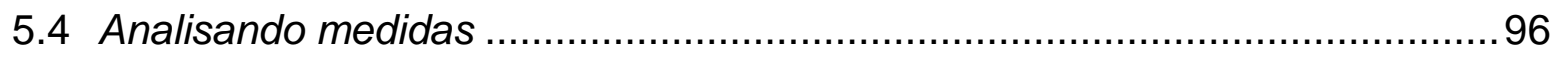

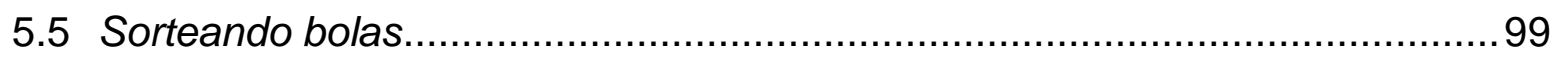

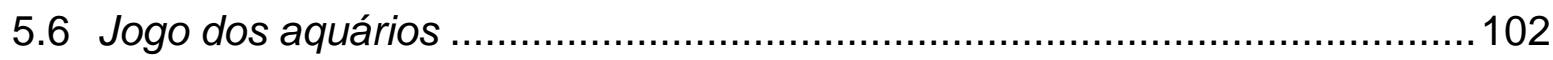

5.7 Juro simples e juro composto ................................................... 105

5.8 Jogo dos arcos de circunferência .................................................... 108

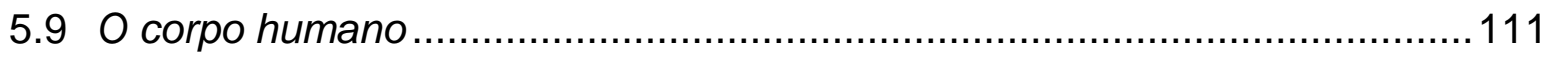

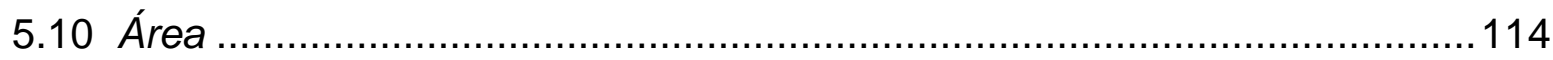

5.11 Equipamentos de mergulho ............................................................ 116

5.12 Cálculo algébrico ................................................................. 119

5.13 Localizando terremotos........................................................ 122

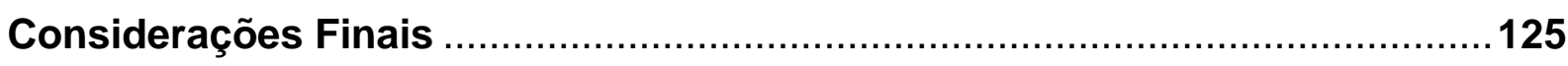

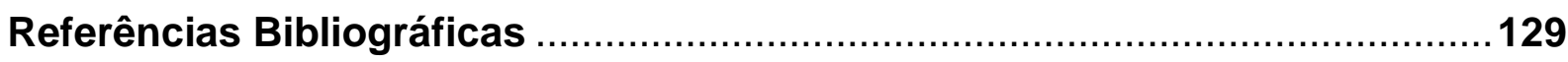




\section{Lista de Abreviaturas}

CAIE - Comitê Assessor de Informática e Educação

CIEd - Centros de Informática na Educação

CNLD - Comissão Nacional do Livro Didático

Colted - Comissão do Livro Técnico e Livro Didático

FAE - Fundação de Assistência ao Estudante

Fename - Fundação Nacional do Material Escolar

FNDE - Fundo Nacional de Desenvolvimento da Educação

GPTEM - Grupo de Pesquisa sobre Tecnologias na Educação Matemática

IBGE - Instituto Brasileiro de Geografia e Estatística

INL - Instituto Nacional do Livro

IME - Instituto de Matemática e Estatística

LDB - Lei de Diretrizes e Bases da Educação Nacional

MEC - Ministério da Educação e Cultura

MIT - Massachusets Institute of Techology

NTE - Núcleos de Tecnologia Educacional

OA - Objetos de Aprendizagem

OED - Objetos Educacionais Digitais

PBLE - Projeto Banda Larga nas Escolas

Plidef - Programa do Livro Didático para o Ensino Fundamental

PNLD - Programa Nacional do Livro Didático

PNLD EJA - Programa Nacional do Livro Didático para Educação de Jovens e Adultos

PNLEM - Programa Nacional do Livro Didático para o Ensino Médio

Prolnfo - Programa Nacional de Tecnologia Educacional

Proninfe - Programa Nacional de Informática Educativa 
PROUCA - Programa Um computador por Aluno

SEI - Secretaria Especial de Informática

TIC - Tecnologias de Informática e Comunicações

UFBA - Universidade Federal da Bahia

UFMG - Universidade Federal de Minas Gerais

UFPE - Universidade Federal de Pernambuco

UFPR - Universidade Federal do Paraná

UFRGS - Universidade Federal do Rio Grande do Sul

UFRJ - Universidade Federal do Rio de Janeiro

UnB - Universidade de Brasília

UNESCO - Organização das Nações Unidas para a Educação, a Ciência e a Cultura

UNICAMP - Universidade de Campinas

USAID - United States Agency for International Development

USP - Universidade de São Paulo 


\section{Lista de Figuras}

Figura 1: A inserção do livro no processo de ensino e aprendizagem de Matemática

Figura 2: Ciclo descrição - execução - reflexão - depuração, proposto por Valente (1999)

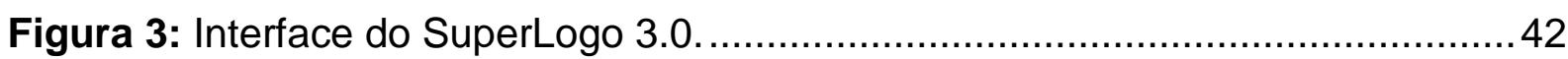

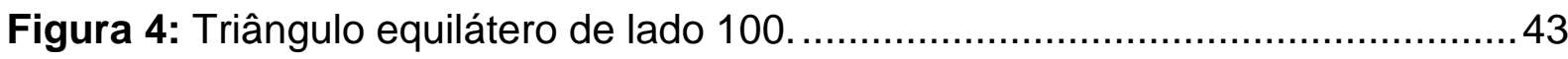

Figura 5: Construção de um triângulo equilátero de lado 100 no SuperLogo 3.0..... 44

Figura 6: Falha na descrição da construção do triângulo equilátero de lado $100 \ldots . . .45$

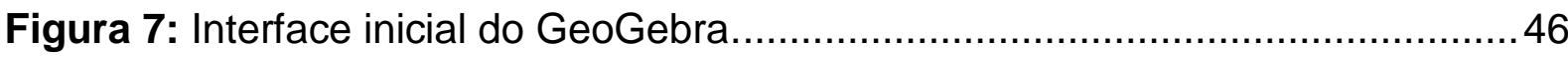

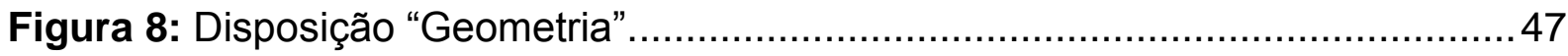

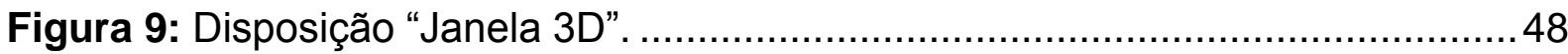

Figura 10: O problema resolvido: triângulo $A B C$ com $A B=8 u, B C=6 u$ e $A C=4 u .48$

Figura 11: Exploração da Figura 10

Figura 12: $\overline{A B}$ com $A B=8 \mathrm{u}$

Figura 13: Circunferência de centro $A$ e raio de medida $4 u$ e circunferência de centro $B$ e raio de medida $6 u$. 50

Figura 14: $O$ ponto $C$ 50

Figura 15: $O$ triângulo $A B C$ com $A B=8 \mathrm{u}, B C=6 \mathrm{u}$ e $A C=4 \mathrm{u}$ 51

Figura 16: Gráfico da função $f(x)=-\left(\frac{x}{2}\right)^{2}+\frac{x}{2}+2$. 52

Figura 17: Cena do filme Tempos Modernos (1936). 62

Figura 18: Circunstâncias para a composição de contextos significativos segundo Spinelli (2011).

Figura 19: Soroban 85

Figura 20: Número 897.561.234 representado no soroban. 86

Figura 21: Cálculos solicitados no "Nível 1". 86 
Figura 22: Cálculos solicitados no "Nível 6".

Figura 23: Tela inicial do OED Números do Brasil...............................................90

Figura 24: Dados referente à região Nordeste. .................................................

Figura 25: Dados referentes ao estado da Bahia...............................................

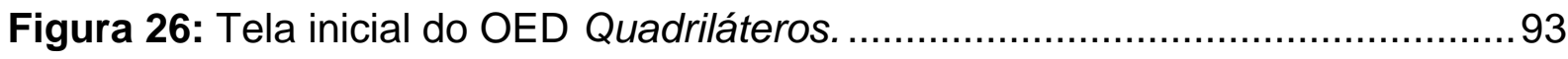

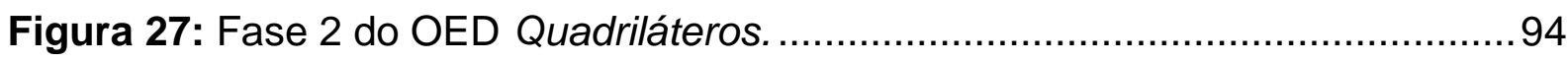

Figura 28: Fase 8 do OED Quadriláteros.......................................................... 94

Figura 29: Tela inicial do OED Analisando Medidas. .............................................96

Figura 30: Medidas de tendência central, máximo e mínimo das idades de 3

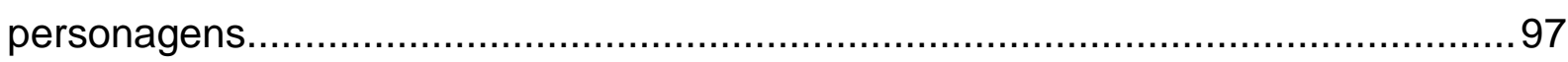

Figura 31: Medidas de tendência central, máximo e mínimo das alturas de 4 personagens incluindo o personagem editável. .................................................97

Figura 32: Tela inicial do OED Sorteando bolas.................................................99

Figura 33: Resultado da simulação de 50 sorteios com reposição de bolas em uma urna que contém 50 bolas vermelhas, 25 verdes, 25 azuis, 75 amarelas e 25 laranjas.

Figura 34: Relatório do experimento ilustrado na figura 33.................................100

Figura 35: Tela inicial do OED Jogo dos aquários. ............................................. 102

Figura 36: Situação da fase 3 do jogo............................................................ 103

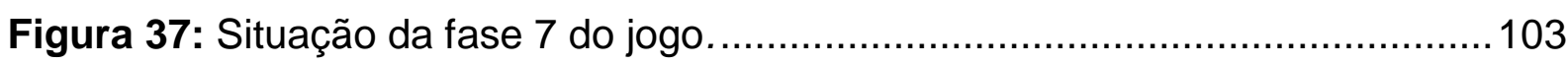

Figura 38: Tela inicial do OED Juro simples e juro composto.............................105

Figura 39: Gráficos dos comportamentos do montante no decorrer do tempo de uma aplicação de $R \$ 1.000,00$ sujeita a uma taxa de juro (simples e composto) mensal de

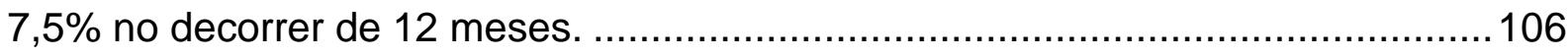

Figura 40: Gráficos dos comportamentos do montante no decorrer do tempo de uma aplicação de $\mathrm{R} \$ 1.000,00$ sujeita a uma taxa de juro (simples e composto) mensal de

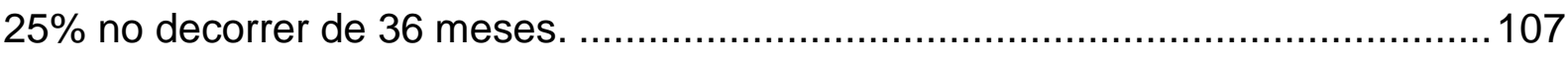

Figura 41: Tela inicial do OED Jogo dos arcos de circunferência.........................108 
Figura 42: Fase 2 do nível "iniciante" do OED Jogo dos arcos de circunferência. . 109

Figura 43: Fase 1 do nível "avançado" do OED Jogo dos arcos de circunferência 109

Figura 44: Tela inicial do OED O corpo humano.

Figura 45: Informações sobre o coração

Figura 46: Informações sobre os rins.

Figura 47: Cena que mostra um hexágono decomposto em triângulos congruentes. Adotando a área de cada triângulo como unidade de área é possível medir a superfície desse hexágono.

Figura 48: Cena que mostra detalhe do papiro Rhind em que constam alguns problemas envolvendo cálculo de áreas de figuras geométricas.

Figura 49: Cena que mostra como determinar a área da superfície de um paralelogramo adotando os quadrinhos do geoplano como unidades de área. 114

Figura 50: Cena que mostra que polígonos diferentes podem ter a mesma área.. 114 Figura 51: Cena que mostra o aperfeiçoamento das roupas de mergulho. 116

Figura 52: Cena que mostra as profundidades de mares e oceanos já alcançadas pelo homem, em virtude da evolução das roupas de mergulho.

Figura 53: Tela inicial do infográfico animado presente no OED Equipamentos de mergulho.

Figura 54: Informações sobre o material de mergulho mais antigo

Figura 55: Informações sobre o material de mergulho usado atualmente. 118

Figura 56: Cena em que é apresentada a fórmula de Pick. 119

Figura 57: Cena que apresenta o significado variáveis presentes na Fórmula de Pick. 119

Figura 58: Cena que mostra como a álgebra pode ser utilizada para descrever um padrão que facilita a determinação da quantidade de pinos encostados, isto é, no contorno de um quadrado representado no geoplano 120 
Figura 59: Cena que mostra como a álgebra pode ser utilizada para descrever um padrão que facilita a determinação da quantidade de pinos no interior de um quadrado representado no geoplano.

Figura 60: Cena que mostra a aplicação da fórmula de Pick para determinar a área de um quadrado de lado 9.

Figura 61: Cena que mostra a aplicação da fórmula de Pick para determinar a área de um polígono irregular. 120

Figura 62: Cena que inicia a demonstração de como determinar a área aproximada da ilha de Galesnjak na Croácia. 120

Figura 63: Cena que mostra que aplicando a fórmula de Pick conclui-se que a área aproximada da ilha de Galesnjak na Croácia é de 62 unidades de área. 120

Figura 64: Cena em que é apresentado o que é o epicentro de um terremoto 122

Figura 65: Cena em que se comenta sobre as ondas $\mathrm{P}$ (laranja) e as ondas $\mathrm{S}$ (amarelo). 122

Figura 66: Cena em que se explica o funcionamento de um sismógrafo. 123

Figura 67: Cena que mostra que com apenas um sismógrafo, conclui-se que o epicentro do terremoto está na circunferência centrada em A e com raio $300 \mathrm{~km} .123$

Figura 68: Cena que mostra que com dois sismógrafos conclui-se que o epicentro do terremoto está no ponto indicado por I ou por II. 123

Figura 69: Cena que mostra que a posição exata do epicentro só é determinada com o auxílio de um terceiro sismógrafo. 123 


\section{Lista de Quadros}

Quadro 1: Comandos básicos do SuperLogo 3.0

Quadro 2: Objeto matemático: uma função linear - representações em diferentes registros.

Quadro 3: Objeto matemático circunferência de centro num ponto e raio dado representações em diferentes registros.

Quadro 4: Exemplos de conversão congruente e não congruente propostos por DUVAL (2009).

Quadro 5: Algumas políticas de implementação da informática nas escolas ............71

Quadro 6: Os OED das obras aprovadas no PNLD 2014. 73

Quadro 7: Caracterização dos OED segundo a relação aluno - OED - tarefa .79

Quadro 8: Caracterização dos OED quanto à mobilização de diferentes registros. 80 Quadro 9: Caracterização dos OED segundo à interdisciplinaridade e contextualização. .82

Quadro 10: Resumo dos critérios e dos níveis. .84

Quadro 11: Cálculo de $66+45$ no soroban. .87

Quadro 12: Cálculo de 81 - 58 no soroban.. .88

Quadro 13: Análise do OED Negócios do Oriente. 89

Quadro 14: Análise do OED Números do Brasil. .92

Quadro 15: Análise do OED Quadriláteros. 95

Quadro 16: Análise do OED Analisando medidas. 98

Quadro 17: Análise do OED Sorteando bolas. 101

Quadro 18: Análise do OED Jogo dos aquários 104

Quadro 19: Análise do OED Juro simples e composto. 107

Quadro 20: Análise do OED Jogo dos arcos de circunferência. 110

Quadro 21: Análise do OED O corpo humano. 113

Quadro 22: Análise do OED Área 115 
Quadro 23: Análise do OED Equipamentos de mergulho. ..............................118

Quadro 24: Análise do OED Cálculo algébrico.................................................121

Quadro 25: Análise do OED Localizando terremotos. .......................................126

Quadro 26: Análise dos OED segundo os critérios estabelecidos. .....................128 


\section{Introdução}

Existe um consenso a respeito das principais características das sociedades contemporâneas: a tecnologia está cada vez mais presente na organização das práticas sociais. Durante as últimas décadas, o desenvolvimento tecnológico assumiu um ritmo sempre crescente, impondo à sociedade mudanças profundas nas formas de comunicação e, também, de acesso à informação, à cultura e ao entretenimento. Criar um site ou um blog, enviar um e-mail, teclar num chat, baixar músicas e clipes, compartilhar fotos e vídeos por meio das redes sociais ou ainda jogar e brincar em rede com amigos virtuais que podem estar, por exemplo, na Europa, na Ásia ou no continente africano são tarefas realizadas cotidianamente pelas pessoas, sobretudo pelos jovens. Isso não só evidencia quão impregnada está a informática em nossas vidas, mas também como a exploramos para interagir e criar juntos.

Como não poderia deixar de ser, as transformações provocadas pela informática na sociedade afetaram a Educação e trouxeram à tona a necessidade de a escola não estar alheia a essas vicissitudes. Segundo D'Ambrosio (2012):

[...] A escola não se justifica pela apresentação de conhecimento obsoleto e ultrapassado e muitas vezes morto. Sobretudo ao se falar em ciências e tecnologia. Será essencial para a escola estimular a aquisição, a organização, a geração e a difusão do conhecimento vivo, integrado nos valores e nas expectativas da sociedade. Isso será impossível de atingir sem a ampla utilização da tecnologia na educação. Informática e comunicações dominarão a tecnologia educativa do futuro. (D'AMBROSIO, 2012, p. 74)

Nesse contexto, a expectativa é de que a escola assuma o papel de formar cidadãos para o mundo, considerado em toda sua complexidade, bem como para os desafios por ele propostos, garantindo, aos alunos, a formação e a aquisição de novas habilidades e atitudes que os possibilitem viver e conviver em uma sociedade em permanente processo de transformação. Para que tal empreitada seja possível, os educadores precisam incorporar as mídias ao currículo, possibilitando que a tecnologia não seja o fim, e sim o meio para possibilitar a igualdade de possibilidades aos indivíduos da sociedade contemporânea. 
Nesse cenário, observa-se o surgimento de aplicativos gerais, como os editores de texto e as planilhas eletrônicas, além de inúmeros software específicos para Educação ${ }^{1}$.

Iniciativas oriundas de políticas governamentais voltadas à integração da informática nas escolas passaram a ser frequentes. Exemplo disso é o fato de o atual Programa Nacional do Livro Didático (PNLD), por meio do Edital do PNLD 2014 (Ensino Fundamental II), contemplar a submissão de Objetos Educacionais Digitais (OED) como parte integrante dos livros.

Os OED são recursos digitais integrados - de modo suplementar - a algumas coleções de livros didáticos compradas pelo Ministério da Educação (MEC) para as escolas públicas dos Estados e Municípios que aderiram ao PNLD. Tais recursos são desenvolvidos com o objetivo de favorecer o processo de ensino e aprendizagem e podem ser apresentados nas categorias audiovisual, jogo eletrônico educativo, simulador, infográfico animado, ou ainda uma mescla de algumas dessas categorias.

Por ser uma medida implementada recentemente, há poucos estudos e reflexões sobre o verdadeiro potencial pedagógico dos OED e de como o professor poderá vir a usufruir deles de modo que contribuam para o engajamento dos alunos e para a superação das dificuldades deles no processo de aprendizagem dos conteúdos matemáticos.

A crença de que os recursos tecnológicos sempre podem trazer contribuições significativas para o processo de ensino e aprendizagem, sobretudo de Matemática, e as poucas pesquisas na área de Educação voltadas aos OED aprovados pelo MEC são as principais motivações para este trabalho, cuja questão norteadora é: quais são

\section{as possíveis contribuições dos OED para a construção do conhecimento em} Matemática?

Machado (2013a) apregoa ser necessário existir um equilíbrio entre o fascínio e o fastio ao lidar com uma nova tecnologia, pois ela resolve certamente muitos problemas, mas também cria outros. Dessa forma, uma nova tecnologia não deve ser rejeitada ou acolhida simplesmente porque é nova, ou seja, não é o "novo" que garante

\footnotetext{
${ }^{1}$ Software específicos para Educação são aqueles desenvolvidos a partir de conceitos, não somente das diferentes áreas e da ciência da computação, como também de preceitos educacionais e da área de ensino.
} 
o valor de uma tecnologia, e sim o que ela tem a nos acrescentar. Nas palavras do autor:

\begin{abstract}
Nada parece mais extemporâneo, no entanto, do que a discussão sobre o uso ou a recusa da tecnologia. Como a técnica nos primórdios da civilização, a tecnologia encontra-se disseminada na sociedade. Sem qualquer melancolia, resta-nos avançar na consciência do significado de sua presença. Se o fascínio automático é típico dos neófitos, a recusa sistemática é, sem dúvida, patética. (MACHADO, 2013a)
\end{abstract}

Ao pretender examinar de que forma os OED contribuem para o processo de ensino e aprendizagem de Matemática, partiremos do pressuposto de que não é o simples fato de esses recursos estarem integrados a algumas coleções de livros didáticos que tornam essas coleções melhores que outras que não os têm.

Diante disso, nos propomos a atingir os seguintes objetivos:

- Estabelecer critérios para examinar o potencial pedagógico dos OED presentes nas coleções de livros didáticos de Matemática aprovadas no PNLD 2014, a partir do referencial teórico empregado;

- Examinar os OED, segundo os critérios estabelecidos.

Para alcançar os objetivos e responder à questão norteadora, a dissertação encontra-se estruturada em capítulos.

Iniciamos com uma reflexão acerca do papel do livro didático no processo de ensino e aprendizagem de Matemática. Em seguida, descrevemos, em linhas gerais, as políticas públicas do livro didático no Brasil de 1929 até 2012, ano em que o PNLD, por meio do Edital do PNLD 2014, contemplou a submissão dos OED. Esses assuntos constituíram o primeiro componente teórico do trabalho e foram tratados no Capítulo 1 - 0 livro didático e o PNLD.

Refletir sobre como Informática pode contribuir para a construção do conhecimento é um importante aspecto de sustentação às considerações teóricas. Tal reflexão ganha corpo no Capítulo 2 - 0 papel dos recursos tecnológicos no processo de ensino e aprendizagem de Matemática. Para tanto, as ideias de Pierre Lévy, Oleg Konstantinovich Tikhomirov e José Armando Valente constituem o embasamento teórico. Suas concepções, em nossa perspectiva, entrelaçam-se, relacionam-se e complementam-se, justificando nossa opção por eles. 
Lévy (1993) entende que o conhecimento se transforma à medida que novas tecnologias intelectuais se tornam disponíveis. O autor aponta, ao considerar a história da humanidade, as influências das tecnologias intelectuais - oralidade, escrita e informática - nas formas de pensamento da sociedade, enfatizando que o surgimento de uma nova tecnologia é acompanhada por uma modificação nas normas do saber. As ideias de Lévy (1993) podem ser consideradas - sobretudo por admitir que a informática interfere na produção de conhecimento - um pano de fundo para as ideias de Tikhomirov (1981) e Valente (1999).

Tikhomirov (1981) analisa o papel do computador e sua relação com a atividade humana. Como será apresentado no Capítulo 2, o autor apresenta três teorias que relacionam tecnologia e cognição: substituição, suplementação e reorganização. É a teoria da reorganização, no entanto, que, segundo ele, expressa o papel essencial da mediação numa atividade humana. Essa teoria sustenta que a construção do conhecimento se dá por meio da relação de interdependência entre o ser humano e o computador, ou seja, o computador é visto como um objeto que molda o ser humano e que, ao mesmo tempo, é moldado por ele.

Valente (1999), por sua vez, analisa como a tecnologia pode ser usada em benefício do processo de construção do conhecimento dos estudantes. Sua visão teórica é inspirada principalmente nos trabalhos de Seymour Papert com a linguagem de programação LOGO. Para Papert (1997, p. 8), a educação tem o papel de "criar contextos adequados para que as aprendizagens possam se desenvolver de modo natural". Assim, o que o autor pretendia com a linguagem de programação LOGO era oportunizar um ambiente problematizador e criativo.

A vantagem de o aluno expressar a resolução de um problema usando essa linguagem de programação é a de que esse recurso fornece um feedback imediato das ações dele. Assim, o aprendiz tem a oportunidade de comparar suas ideias iniciais com o resultado obtido com o uso do software, analisar e refletir sobre seus acertos e erros, levantar hipóteses, realizar novas tentativas, verificar conceitos e as estratégias empregadas e, assim, construir novos conceitos. Nesse contexto, Valente (1999) vê o aluno como protagonista e o computador como uma "máquina para ser ensinada". Ele vislumbra a realização do ciclo descrição - execução - reflexão - depuração. Aliás, tal ciclo, como veremos, pode se concretizar em atividades que não são necessariamente de programação. 


\section{No Capítulo 3 - Na busca da construção de um conhecimento matemático}

significativo, descrevemos, em linhas gerais, a teoria dos registros de representação semiótica, proposta por Raymond Duval. Como veremos, o autor defende a tese de que a aquisição conceitual está ancorada na coordenação de diversos registros semióticos de representação.

Também no Capítulo 3, abordamos temas como interdisciplinaridade e contextualização do ensino, buscando elementos teóricos que possam contribuir para a compreensão de aspectos importantes a serem respeitados na composição contextual com vistas a proporcionar aos alunos uma aprendizagem matemática significativa. Encontramos especialmente nas obras de dois autores - Machado (2011) e Spinelli (2011) - as respostas que buscávamos e as descrevemos no referido capítulo.

O Capítulo 4 - A pesquisa propriamente dita: os Objetos Educacionais Digitais nos livros didáticos (PNLD 2014) inicia-se com uma descrição, em linhas gerais, das políticas e inciativas governamentais brasileiras relacionadas à inserção da informática na escola de 1981 até 2012, ano no qual o PNLD, por meio do Edital do PNLD 2014, contemplou a submissão dos OED. Além disso, foi feito um levantamento dos OED aprovados no PNLD 2014 e destacamos a importância da interface para a efetivação das propostas pedagógicas presentes nos software voltados para o ensino.

Nesse capítulo, apresentamos, também, os critérios e os respectivos níveis de pertinência adotados para a análise dos OED. A escolha dos critérios está amparada nas concepções de conhecimento e aprendizagem que foram sendo construídas por meio de reflexões e debates vivenciados em minha formação.

Em uma sociedade cada vez mais informatizada, cabe ao professor a responsabilidade de análise da adequação de recursos tecnológicos em sala de aula, com o intuito de promover a construção do conhecimento e não somente a sua transmissão. Nesse contexto, é primordial analisar crítica e individualmente cada OED, o que é feito no Capítulo 5 - 0 exame dos OED. Tal análise é realizada respeitando os critérios estabelecidos no Capítulo 4.

A resposta à questão norteadora e as indicações para futuros trabalhos são encontradas nas Considerações Finais. 
Evidentemente, este trabalho não pretende estabelecer uma classificação dos OED, mas sim compreender de que forma esses recursos podem contribuir para o processo de ensino e aprendizagem de Matemática, permitindo aos alunos que vivenciem experiências matemáticas enriquecedoras. 


\section{Capítulo 1}

\section{O livro didático e o PNLD}

\section{$1.1 \quad$ papel do livro didático}

É indiscutível a importância do livro didático no processo de ensino e aprendizagem das mais diversas áreas do saber, não somente por ser ele uma referência, mas também por fornecer ao professor caminhos que o ajudam a guiar seus alunos rumo à aprendizagem. Nesse sentido, o livro didático constitui uma ferramenta capaz de provocar e nortear possíveis mudanças e aperfeiçoamentos na prática pedagógica, sendo, portanto, um recurso imprescindível tanto para o professor quanto para os alunos.

Machado (2015) entende que a importância do livro didático está, em especial, na sua relação de complementaridade com o caderno do aluno. Para ele, o elo entre o livro e o caderno é fundamental para a construção do conhecimento. Em suas palavras:

\footnotetext{
O livro didático é o aliado natural do caderno na construção do conhecimento. Conhecer é conhecer o significado e somente se chega ao significado por meio do sentido. O sentido é pessoal, idiossincrático, mas os múltiplos sentidos interceptam-se, incluem regiões comuns, percebidas por todos, ou a vida em sociedade seria impossível. (MACHADO, 2015)
}

Ainda, segundo o autor: "Na escola, é crucial a articulação entre as diferenças pessoais e a necessária racionalidade na partilha de interesses com os outros." (MACHADO, 2015). Nesse âmbito, o caderno é concebido como o espaço dos registros pessoais do aluno e do conhecimento em construção; já o livro didático é compreendido como o espaço em que o conhecimento se encontra sistematizado, sendo, portanto, o lugar dos significados a serem partilhados. Isso não só justifica a aposta do autor na relação de interdependência entre o livro e o caderno para a construção do conhecimento, como também evidencia a importância do livro didático para a formação do aluno. 
Sobre a inserção do livro didático no processo de ensino e aprendizagem de Matemática, convém também destacar a opinião de Carvalho e Lima (2010):

\begin{abstract}
O livro didático traz para o processo de ensino e aprendizagem mais um personagem, o seu autor, que passa a dialogar com o professor e com o aluno. Nesse diálogo, o livro é portador de escolhas sobre: o saber a ser estudado - no nosso caso, a Matemática -; os métodos adotados para que os alunos consigam aprendê-lo mais eficazmente; a organização curricular ao longo dos anos de escolaridade. (CARVALHO; LIMA, 2010, p. 15)
\end{abstract}

Dessa forma, para Carvalho e Lima, fica estabelecida "uma teia de relações interligando quatro polos: um deles é formado pelo autor e o livro didático; [enquanto] o professor, o aluno e a Matemática compõem os outros três". Desse modo, eles propõem o seguinte esquema:

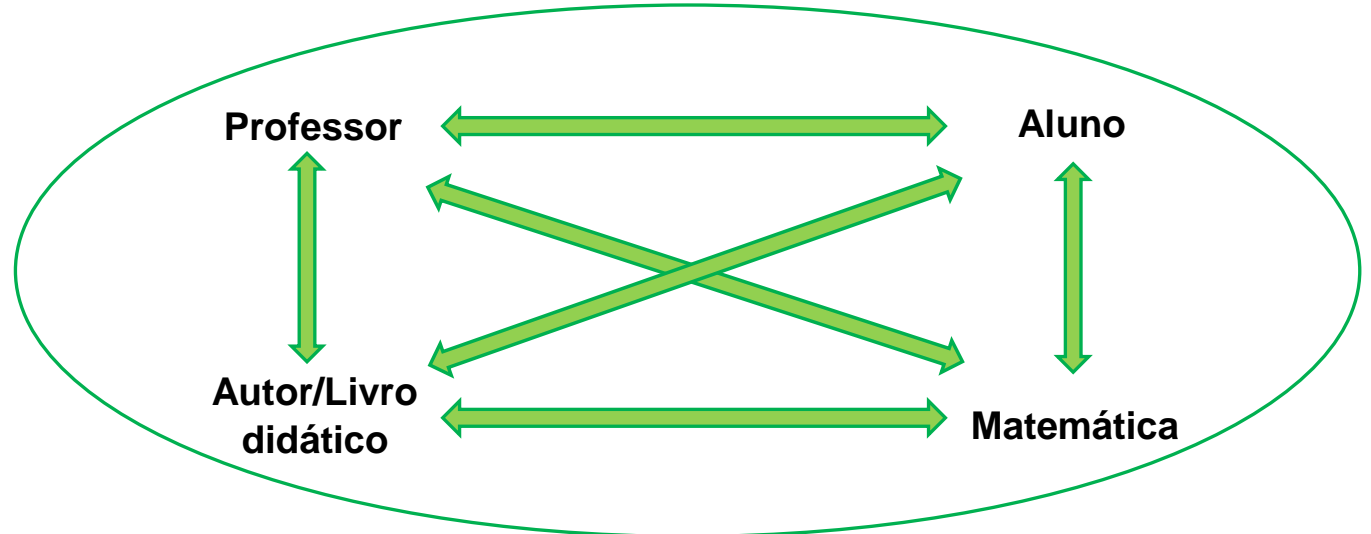

Figura 1: A inserção do livro didático no processo de ensino e aprendizagem de Matemática.

Fonte: Carvalho e Lima (2010, p. 15).

É comum, no entanto, o livro didático ser usado como único suporte ao trabalho do professor. Sobre esse uso, Machado (1996) afirma:

O professor abdica do privilégio de projetar os caminhos a serem trilhados, em consonância com as circunstâncias - experiências, interesses, perspectivas - de seus alunos, passando a conformar-se, mais ou menos acriticamente, com o encadeamento de temas propostos pelo autor. (MACHADO, 1996, p. 31)

Nesse caso, o livro didático se configura como selecionador de conhecimentos e orientador de métodos pedagógicos, levando o professor a ensinar os conteúdos 
segundo uma metodologia definida a priori, sem considerar os interesses e conhecimentos prévios de seus alunos.

As falhas na formação inicial e continuada dos professores merecem especial atenção e contribuem de maneira decisiva para a posição hegemônica que o livro didático ocupa entre os demais recursos, como materiais concretos e recursos tecnológicos. É frequente a crítica de que predomina nos cursos de formação a abordagem tecnicista, excluindo dessa etapa um trabalho de pensamento crítico e reflexivo. Segundo Machado (2006),

\begin{abstract}
$\mathrm{Na}$ formação de profissionais da Educação para atuar em todos os níveis do ensino, muitas vezes a ênfase situa-se na competência técnica, no domínio dos conteúdos de um conjunto de disciplinas específicas, sem que se dê suficiente relevo às outras dimensões que caracterizam um profissional. Sem comprometimento, sem o sentimento profundo de contribuir para o bem comum, sem o reconhecimento social que viabiliza uma autorregulação de suas atividades, sem a dignidade e o orgulho de sentir-se um servidor público, independentemente de qual a fonte que propicia o pagamento de seus salários, não se pode falar propriamente de profissional da Educação. (MACHADO, 2006, p. 48)
\end{abstract}

No caso especifico da Matemática, D’Ambrosio (1993) alega que é desejável, para o século $\mathrm{XXI}$, o professor ter visão do que vem a ser matemática e do que constitui a atividade matemática, além também, da visão do que constitui a aprendizagem matemática e um ambiente propício à aprendizagem matemática.

Sobre a visão do que vem a ser matemática, a autora aponta para a importância de se compreender a Matemática como uma disciplina de investigação e não apenas como uma disciplina pautada em resultados precisos e procedimentos infalíveis, sendo relevante ainda que o professor entenda que a Matemática estudada deve, de alguma forma, se aproximar da realidade dos alunos, contribuindo para a compreensão, explicação ou organização da realidade deles.

No que diz respeito à visão do que constitui a atividade matemática, D’Ambrosio (1993) entende que é desejável que o professor proporcione aos seus alunos legítimas experiências matemáticas, ou seja, que os alunos passem a fazer matemática vivenciando as experiências de um matemático.

Assim como no processo de construção da Matemática como disciplina a essência do processo é a pesquisa, na construção do conhecimento para o aluno, a essência do processo tem que ser a pesquisa. Dificilmente o aluno 
de Matemática testemunha a ação do verdadeiro matemático no processo de identificação e solução de problemas. [...] O professor, com isso, guarda, para si a emoção da descoberta de uma solução fascinante, da descoberta de um caminho produtivo, das frustrações inerentes ao problema considerado e de como um matemático toma decisões que facilitam a solução do problema proposto. (D'AMBROSIO, 1993, p. 36)

A visão do que constitui a aprendizagem matemática liga-se umbilicalmente com a de um ambiente propício para a aprendizagem matemática. D’Ambrosio (1993) sinaliza que o professor deve ajudar o aluno a não ser um recipiente passivo de fatos e ideias. Nesse sentido, um ambiente propício à aprendizagem matemática é aquele no qual os alunos propõem, exploram e investigam problemas matemáticos oriundos tanto de situações reais (modelagem) quanto de situações lúdicas (jogos e curiosidades) e de investigações ou refutações dentro da própria Matemática. Segundo a autora:

O ambiente proposto é um ambiente positivo que encoraja os alunos a propor soluções, explorar possibilidades, levantar hipóteses, justificar seu raciocínio, validar suas próprias conclusões. Respostas "incorretas" constituem a riqueza do processo de aprendizagem e devem ser exploradas e utilizadas de maneira a gerar novo conhecimento, novas questões, novas investigações ou um refinamento das ideias existentes. (D'AMBROSIO, 1993, p. 37)

As características apontadas sinalizam, segundo a própria autora, para a necessidade de que os programas de formação de professores sejam modificados. Estudos indicam que o professor - principalmente o iniciante - ensina da maneira como the foi ensinado: expondo o conteúdo, mostrando como resolver alguns exemplos e propondo aos alunos que resolvam vários exercícios semelhantes. Isso revela uma visão de ensino ancorada na passividade do aluno, na qual o seu papel se reduz a imitar os passos do professor na resolução de questões ligeiramente diferentes dos exemplos. Essa situação assemelha-se à do professor diante do livro didático, uma vez que ele fica refém dos encadeamentos propostos pelo autor, abraçando quase que na totalidade as metodologias propostas nas obras. Assim, se por um lado o aluno recebe instruções passivamente do professor, por outro, o professor recebe instruções passivamente do livro didático. O professor - da mesma forma que transmite aos alunos informações prontas que lhes inibem a reflexão, preparando com antecedência exercícios que os levam a testemunhar uma solução bonita e eficiente, sem obstáculos e sem dúvidas - acata sem questionar o que the apresenta o livro didático, o qual traz 'receitas' de como ele deve conduzir sua prática. 
É nesse contexto que os manuais do professor agregaram importância, sobretudo nas avaliações do MEC, pois, além de trazerem os pressupostos teóricometodológicos que fundamentam a proposta didático-pedagógica da obra, orientam o modo como o professor deve usar o livro didático.

Como se pode depreender do cenário acima esboçado, as falhas na formação do professor justificam em parte o modo como ele usa o livro didático. Sobre como essas falhas podem ser superadas, D'Ambrosio (1993) comenta:

\begin{abstract}
O seu aprendizado de matérias como Cálculo, Álgebra, Probabilidade, Estatística e Geometria, no ensino superior, deve visar à investigação, à resolução de problemas, às aplicações, assim como uma análise histórica, sociológica e política do desenvolvimento da disciplina. Isso exige uma nova percepção por parte dos matemáticos de como se aprende Matemática, o que para muitos está além de suas preocupações. Portanto, a mudança de cursos formais de Matemática é tamanha utopia que exige da comunidade de educadores matemáticos a procura de alternativas criativas para que o futuro do professor tenha legítimas experiências matemáticas simulando as atividades de uma comunidade de pesquisa matemática. (D'AMBROSIO, 1993, p. 39)
\end{abstract}

Somam-se à questão das falhas na formação, as más condições de trabalho do professor e o sentimento de desprofissionalização que assola a categoria, o que acaba por desencorajá-lo a refletir criticamente sobre sua prática e a desenvolver um olhar consciencioso sobre o livro didático. É por meio desse olhar que o professor será capaz de redimensionar o papel do livro didático e proporcionar aos seus alunos experiências variadas, interessantes e significativas.

Segundo Carvalho e Lima (2010), na contramão dos que fazem do livro didático o seu único recurso pedagógico, estão os professores que abdicam do seu uso ou o usam muito pouco, ainda que esteja disponível. Eles desperdiçam, assim, um recurso didático precioso. Desistir do livro didático de Matemática é abrir mão de uma fonte de pesquisa e de sugestões de propostas pedagógicas que podem articular a Matemática com sua história e também com as demais disciplinas; é fazer com que propostas que envolvam o uso de recursos tecnológicos - que podem ser de grande valia para o processo de ensino e aprendizagem - caiam no ostracismo. Tudo isso contribui para reforçar a concepção dos alunos de que a Matemática é uma disciplina descolada das outras e da realidade. 
Qual seria, então, o papel do livro didático no processo de ensino e aprendizagem de Matemática?

Na tentativa de responder a essa pergunta, o primeiro ponto a se destacar é o fato de que o livro didático não deve ser negligenciado, nem tampouco superestimado, devendo ser encarado, portanto, como um recurso auxiliar no processo de ensino e aprendizagem. A esse respeito, Machado (1996, p. 32) afirma que "[...] utilizado de modo adequado, o livro mais precário é melhor do que nenhum livro, enquanto o mais sofisticado dos livros pode tornar-se pernicioso se utilizado de modo catequético".

Ainda, segundo o mesmo autor:

[...] o livro didático precisa ter o seu papel redimensionado, diminuindo-se sua importância relativamente a outros instrumentos didáticos, como o caderno, seu par complementar, e outros materiais, de um amplo espectro que inclui textos paradidáticos, não didáticos, jornais, revistas, redes informacionais, etc. A articulação de todos esses recursos, tendo em vista as metas projetadas para as circunstâncias concretas vivenciadas por seus alunos, é uma tarefa da qual o professor jamais poderá abdicar e sem a qual seu ofício perde muito de seu fascínio. (MACHADO, 1996, p. 31 -32)

Em consonância com essa ideia, Dante (1996), afirma que:

[...] o ideal é que o livro didático seja mais para inspirar do que para ser rigidamente seguido. $\mathrm{E}$, à medida que o aluno e o professor avançam com o livro, eles o completam, suplementam, reorganizam, recriam, enfim, escrevem o seu próprio livro. Nesse sentido, como matéria-prima para todos esses desenvolvimentos, o livro didático torna-se essencial. (DANTE, 1996, p. 90)

As ideias de ambos os autores convergem para o fato de que o processo de ensino e aprendizagem não deve estar centrado apenas no livro didático, devendo este ter o seu papel redimensionado. Tal ação implica na valorização de outros recursos pedagógicos - materiais concretos, recursos tecnológicos etc. -, os quais podem possibilitar que os alunos vivenciem experiências que os levem a atribuir significado aos conteúdos disciplinares. Apostar todas as fichas no livro didático ou abdicar de seu uso certamente é um equívoco.

A seguir, vamos apresentar um panorama de como se desenvolveram as políticas do livro didático no Brasil até a consolidação do Programa Nacional do Livro Didático (PNLD). 


\subsection{As políticas do livro didático no Brasil: das origens à consolidação do PNLD}

A história dos processos de avaliação do livro didático no Brasil evoluiu a partir de 1929 com a criação do Instituto Nacional do Livro (INL). O INL era um órgão específico para legislar sobre políticas do livro didático, com a finalidade de legitimálo e, consequentemente, aumentar a produção dele (FNDE, 2012).

Em 1938, foi instaurada a Comissão Nacional do Livro Didático (CNLD), por meio do Decreto-lei no 1.006, de 30 de dezembro de 1938, em que foram estabelecidas as condições de produção, importação e utilização do livro didático no país (FNDE, 2012). Segundo o Art. 3 o desse Decreto-lei, os livros didáticos que não tivessem autorização prévia concedida pelo Ministério da Educação nos termos da lei, a partir de 10 de janeiro de 1940, não poderiam ser adotados no ensino das escolas primárias, normais, profissionais e secundárias, em toda a República. Se, por um lado, havia restrições quanto às obras que podiam ser adotadas, por outro, no Art. 6으, era dada ao professor a liberdade de escolher como empregaria os livros adotados, desde que respeitasse a orientação didática dos programas escolares.

Após sete anos, o Decreto-lei o 1.006 foi alterado pelo Decreto-lei ํo 8.460, de 26 de dezembro de 1945. Esse novo decreto manteve a estrutura e as linhas gerais do anterior, porém introduziu novas diretrizes, como o veto à mudança do livro no decurso do ano escolar, no Art. 7ำ, e a atribuição ao INL da incumbência da publicação oficial dos livros didáticos, no Art. 9 (CURY, 2009, p. 123).

O passo seguinte deu-se em 1966, quando, a partir do acordo entre o Ministério da Educação (MEC) e a United States Agency for International Development (USAID) $^{2}$, foi criada a Comissão do Livro Técnico e Livro Didático (Colted), cujo objetivo era coordenar as ações referentes à produção, edição e distribuição do livro didático. Por intermédio desse acordo, o MEC assegurou recursos suficientes para distribuir gratuitamente 51 milhões de livros didáticos no período de três anos (FNDE, 2012). Enquanto o MEC tinha a responsabilidade de execução, a USAID controlava a elaboração, ilustração, editoração e distribuição dos livros.

\footnotetext{
${ }^{2}$ A USAID (Agência Norte-Americana para o Desenvolvimento Nacional) é um órgão independente do governo federal dos EUA responsável por programas de assistência econômica e humanitária em todo o mundo (EMBAIXADA DOS ESTADOS UNIDOS NO BRASIL, 2015).
} 
Ao que tudo indica, o interesse dos EUA nesses acordos com o Brasil e, também com outros países da América do Sul, era garantir a vigência do sistema capitalista e difundir os ideais de organização social, política e econômica que prevaleciam nos Estados Unidos. Sobre o livro didático nesse período, Silva (2010) afirma que:

\footnotetext{
O livro didático, produto desse contexto, passa a veicular valores e práticas norte-americanas, assim como conteúdos e metodologias 'atualizadas' ou 'modernizadas' seguindo as principais pesquisas desenvolvidas nos países dentro da esfera de influência cultural dos EUA. (SILVA, 2010, p. 88)
}

No ano de 1970, todavia, com recursos do INL, o Ministério da Educação implementou o sistema de coedição de livros com editoras nacionais. Um ano depois, após ser envolvida numa série de denúncias de irregularidades, a Colted foi extinta e suas atribuições foram incorporadas ao INL, que, além de assumir as atribuições administrativas e de gerenciamento dos recursos financeiros, passou a desenvolver o Programa do Livro Didático para o Ensino Fundamental (Plidef). Após o término do convênio MEC/USAID, a contrapartida dos estados tornou-se necessária e, por esse motivo, foi implantado o sistema de contribuição financeira das unidades federadas para o Fundo do Livro Didático, com a intenção de manter o fornecimento de livros para os alunos carentes (FNDE, 2012). Assim, "de censor oficial dos livros didáticos usados nas escolas brasileiras, o Estado foi assumindo também o papel de financiador dos mesmos livros." (HÖFLING, $1993^{3}$ apud FILGUEIRAS, 2011, p. 202)

Em 1976, por meio do Decreto № 77.107, de 4 de fevereiro de 1976, o governo assumiu a compra de boa parcela dos livros para distribuí-los às escolas. Com recursos provindos das contribuições das unidades federadas e do Fundo Nacional de Desenvolvimento da Educação (FNDE), a Fundação Nacional do Material Escolar (Fename) tornou-se responsável pela execução do programa do livro didático, após a extinção do INL (FNDE, 2012).

No ano de 1983, a Fename foi transformada na Fundação de Assistência ao Estudante (FAE), que incorporou o Plidef. A proposta de participação dos professores na escolha dos livros e a ampliação do programa, com a inclusão das demais séries

\footnotetext{
${ }^{3}$ HÖFLING, Eloisa de Mattos. 1993. A FAE e a execução da política educacional: $1983-1988$. Doutorado, Faculdade de Educação, Unicamp.
} 
do ensino fundamental, aconteceram nesse ano, por causa da iniciativa do grupo de trabalho encarregado do exame dos problemas relativos aos livros didáticos (FNDE, 2015).

Em 19 de agosto de 1985, com a edição do Decreto no 91.542, surgiu, em substituição ao Plidef, o Programa Nacional do Livro Didático (PNLD), que trouxe diversas mudanças, conforme cita o FNDE (2012):

- Indicação do livro didático pelos professores;

- Reutilização do livro, implicando a abolição do livro descartável e o aperfeiçoamento das especificações técnicas para sua produção, visando maior durabilidade e possibilitando a implantação de bancos de livros didáticos;

- Extensão da oferta aos alunos de $1^{\underline{a}}$ e $2^{\underline{a}}$ série das escolas públicas e comunitárias;

- Fim da participação financeira dos estados, passando o controle do processo decisório para a FAE e garantindo o critério de escolha do livro pelos professores.

Convém destacar que, até a década de 1980, as políticas do livro didático no Brasil estiveram voltadas para a promulgação de diversos decretos-lei e iniciativas governamentais que criaram comissões e acordos para regulamentar uma política aceitável para a produção e para a distribuição de livros.

Para que a melhoria qualitativa do livro didático fosse efetivamente conseguida, foram definidos, em 1993/1994, os primeiros critérios para avaliação de livros didáticos com a publicação "Definição de Critérios para Avaliação dos Livros Didáticos" feita pelo MEC, FAE e UNESCO 4 . Somente após dois anos, porém, iniciouse o processo de avaliação pedagógica dos livros inscritos no PNLD com a publicação do primeiro "Guia de livros didáticos" de 1a a 4⿳亠丷a séries. O procedimento de avaliação foi se aperfeiçoando ao longo dos anos, sendo aplicado até hoje.

A necessidade de avaliar livros se fez importante à medida que estudos denunciavam a falta de qualidade deles, apontando problemas sérios, como a ocorrência de erros conceituais, a introdução de elementos que induziam a erros, a desatualização das informações e a veiculação de ideologias e preconceitos, além das acentuadas deficiências metodológicas. Ao mesmo tempo, todavia, que a política de avaliação do livro didático no Brasil passava a ter como base o estabelecimento de

\footnotetext{
${ }^{4}$ Organização das Nações Unidas para a Educação, a Ciência e a Cultura.
} 
parâmetros de qualidade, esses, de maneira intencional ou não, inibiam a livreiniciativa de produção.

Em 1997, com a extinção da FAE, a responsabilidade pela política de execução do PNLD foi transferida integralmente para o FNDE. O programa foi ampliado e o Ministério da Educação passou a adquirir, de forma continuada, livros didáticos de alfabetização e das disciplinas que compunham o currículo do Ensino Fundamental para todos os alunos (FNDE, 2012).

De 2000 a 2010, o PNLD ampliou o atendimento aos alunos, sobretudo com a criação do Programa Nacional do Livro Didático para o Ensino Médio (PNLEM) em 2003 e do Programa Nacional do Livro Didático para Educação de Jovens e Adultos (PNLD EJA) em 2009. Nesse período, passaram a ser atendidos também os alunos com deficiência visual e auditiva, com livros didáticos em braile ${ }^{5}$ e a distribuição do dicionário enciclopédico ilustrado trilíngue (Língua Brasileira de Sinais, Língua Portuguesa, Língua Inglesa). O FNDE passou a adquirir e distribuir sistematicamente livros para todos os níveis de ensino, inclusive para a Educação de Jovens e Adultos (FNDE, 2012).

Segundo o FNDE, no ano de 2012, um "importante e significativo avanço nos programas do livro (didático) ocorreu na área de tecnologia", com a publicação de um edital, cujo objetivo era:

[...] a constituição de acordos de cooperação entre o FNDE e instituições interessadas para a estruturação e a operação de serviço virtual para disponibilização de obras digitais e outros conteúdos educacionais digitais para professores, estudantes e outros usuários da rede pública de ensino brasileira, com ênfase nos títulos do Programa Nacional do Livro Didático (PNLD), do Programa Nacional Biblioteca da Escola (PNBE) e de outras ações governamentais na área de material escolar, por meio de tecnologia que assegure $o$ atendimento em escala nacional e proteja os direitos autorais digitais e a propriedade intelectual dos acervos. (FNDE, 2012)

Em 2012, as editoras participantes do PNLD 2014 podiam inscrever objetos educacionais digitais (jogos, vídeos, simuladores, animações etc.) relativos aos textos dos livros impressos. Além disso, como uma forma de tornar as aulas mais "modernas e interessantes", estava previsto que os livros didáticos indicassem endereços na web

\footnotetext{
${ }^{5}$ Atualmente, esses alunos são atendidos também com livros em libras, com tamanho ampliado da fonte, e na versão Mecdaisy, que consiste de um programa que permite transformar qualquer formato de texto disponível no computador em texto digital falado (FNDE, 2012).
} 
por meio dos quais os alunos pudessem ter acesso ao material multimídia e também complementar assuntos abordados (FNDE, 2012). Os editais do PNLD passaram a englobar continuamente diferentes formatos e exigências relacionadas a conteúdos digitais.

Vale ressaltar que, para viabilizar a participação das editoras que não estavam preparadas, a inclusão dos objetos educacionais digitais não era obrigatória e continua não sendo até hoje. Essa demanda do MEC, contudo, vem causando mudanças nas editoras, fazendo com que elas invistam na contratação de profissionais especializados e de empresas de tecnologia, em pesquisas e no desenvolvimento, além de na formação e no treinamento de suas equipes. Esses esforços justificam-se, pois livros com conteúdo digital associado podem fazer mais sucesso entre os professores, aumentando a possibilidade de que sejam adotados.

O legado desses mais de 80 anos, desde que a primeira política relacionada ao livro didático foi implantada, não se restringe apenas aos expressivos investimentos em livros didáticos e ao número de alunos beneficiados. Os livros tornaram-se objeto de pesquisa e reflexão, passando a privilegiar a ideia de ensino voltada para a construção de competências, sem dispensar, porém, a construção de saberes. Assim, competências como interpretar matematicamente situações do dia a dia ou de outras áreas do conhecimento, generalizar, estimar, efetuar cálculos mentalmente, trabalhar em equipe, compreender e transmitir ideias matemáticas, por escrito ou oralmente etc., passaram a ser perseguidas pelos livros didáticos, que, no entanto, não abriram mão dos conteúdos.

Além disso, a iniciativa de aliar ao livro impresso os objetos educacionais digitais revela a preocupação em mudar as práticas pedagógicas vigentes com o objetivo de melhorar o processo de ensino e aprendizagem das disciplinas curriculares.

Na busca de compreender o potencial pedagógico desses objetos educacionais digitais, o próximo capítulo será dedicado ao modo como os recursos tecnológicos podem se inserir no processo de ensino e aprendizagem de Matemática a fim de gerarem resultados significativos. 


\section{Capítulo 2}

\section{O papel dos recursos tecnológicos no processo de ensino e aprendizagem de matemática}

A sociedade, de modo geral, vem desfrutando dos progressos da informática sem, muitas vezes, ter consciência disso. Ler um jornal, assistir à programação da televisão, usar um telefone, pagar uma conta no banco, fazer compras em um supermercado são situações em que a informática está normalmente presente, fornecendo indícios de que mudanças vêm ocorrendo na maneira de as pessoas se relacionarem com seus pares e com o meio em que estão inseridas. Tais mudanças trazem reflexos também no modo como o conhecimento é produzido e apreendido. Nas palavras do filósofo francês Pierre Lévy (1998),

A mediação digital remodela certas atividades cognitivas fundamentais que envolvem a linguagem, a sensibilidade, o conhecimento e a imaginação inventiva. A escrita, a leitura, a escuta, o jogo e a composição musical, a visão e a elaboração das imagens, a concepção, a perícia, o ensino e o aprendizado, reestruturados por dispositivos técnicos inéditos, estão ingressando em novas configurações sociais. (LÉVY, 1998, p. 17)

A informática em conjunto com a oralidade e a escrita são denominadas tecnologias intelectuais por esse autor, que procura analisar a influência de cada uma delas, em particular da informática, nas formas de pensamento da sociedade. Segundo ele, o surgimento de uma nova tecnologia intelectual culmina em uma reorganização do pensamento - criando e resolvendo problemas - sem, no entanto, extinguir a anterior.

A oralidade era uma extensão da memória dos indivíduos cuja ativação se dava por meio de ritos e narrativas: formas pelas quais a pessoa construía uma representação do fato que desejasse lembrar. Lévy (1993) deu a essa estratégia o nome de elaboração. $\mathrm{O}$ autor baseou-se nas experiências descritas em trabalhos de psicologia cognitiva para concluir que essas elaborações se mostravam mais eficientes do que a simples memorização. Em suas palavras, 
lembrança da informação-alvo persistia por vinte e quatro horas, mas depois tendia a apagar-se. Por outro lado, quando Ihes era sugerido que se lembrassem da lista construindo pequenas histórias ou imagens envolvendo as palavras a serem lembradas, as performances eram médias a curto prazo, mas persistiam por um longo tempo. (LÉVY, 1993, pp. 79, 80)

Se, por um lado, as elaborações auxiliavam as pessoas a lembrarem determinado fato, por outro, elas o distorciam, uma vez que eram interpretações das mensagens originais.

Outro inconveniente, segundo o mesmo autor, era a necessidade de retomar e repetir em voz alta, constantemente, as informações e proposições para que elas não desaparecessem.

Essas dificuldades foram se acentuando conforme o número de informações cresceu, o que fez com que uma nova tecnologia passasse a coexistir com a oralidade: a escrita.

Para o filósofo, o surgimento da escrita gerou uma situação diferente na difusão das informações: uma vez que não havia mais a dependência da mediação humana, como acontecia nas sociedades orais, as informações não eram corrompidas pelas elaborações. A partir da escrita, deu-se a autonomia da informação.

Ao contrário das sociedades orais, nas quais predominavam a repetição e a memorização como formas de transmissão e aquisição de conhecimentos, a sociedade da escrita impõe a necessidade da compreensão dos signos linguísticos. O conhecimento deles abre a possibilidade de uma distância física e temporal entre a pessoa que transmite o conhecimento e aquela que o recebe: os tempos em que ocorrem os dois processos - escrever e ler - podem estar defasados de muitos séculos, milênios até.

Se, por um lado, a escrita libertou o pensamento humano da obrigatoriedade de memorização permanente, por outro, a separação entre tempos e espaços de escrita e leitura pode gerar versões e interpretações diferenciadas para o mesmo texto. Nas palavras do mesmo autor, "a escrita, ao intercalar um intervalo de tempo entre a emissão e a recepção da mensagem, instaura a comunicação diferida, com todos os riscos de mal-entendidos, de perdas e erros que isso implica" (LÉVY, 1993, p. 88). 
Nesse âmbito, paulatinamente, passou a coexistir com a oralidade e a escrita uma tecnologia intelectual pautada, sobretudo, na comunicação instantânea entre pessoas, mesmo que estivessem em espaços físicos distintos, a qual, agregando as imagens e os sons, ultrapassa os limites da escrita manuscrita e da impressão: a informática. Sobre o advento da informática, o mesmo autor ressalta:

\begin{abstract}
A informática parece reencenar, em algumas décadas, o destino da escrita: usada primeiro para cálculos, estatísticas, a gestão mais prosaica dos homens e das coisas, tornou-se rapidamente uma mídia de comunicação de massa, ainda mais geral, talvez, que a escrita manuscrita ou a impressão, pois também permite processar e difundir o som e a imagem enquanto tais. A informática não se contenta com a notação musical, por exemplo, ela também executa a música. (LÉVY, 1993, p. 117)
\end{abstract}

Ainda segundo o filósofo, o tempo na sociedade oral era circular por haver a constante necessidade de se repetir em voz alta as informações e proposições. Já na sociedade em que a escrita estava disseminada, o tempo era linear, visto ser indispensável que as informações fossem organizadas de forma sistemática para que fossem preservadas e posteriormente transmitidas.

Com relação ao tempo nas sociedades informatizadas 6 , o autor afirma que, "por analogia com o tempo circular da oralidade primária ${ }^{7}$ e o tempo linear das sociedades históricas ${ }^{8}$, poderíamos falar de uma espécie de implosão cronológica, de um tempo pontual instaurado pelas redes da informática." (p.115). Dessa forma, a Informática rompe com as formas narrativas circulares e repetidas da oralidade e com 0 encaminhamento contínuo e sequencial da escrita e se apresenta como um fenômeno descontínuo, fragmentado e, ao mesmo tempo, dinâmico, aberto e veloz. Aliás, a velocidade é a marca dessa nova tecnologia, colocando em xeque, inclusive, a noção de memória, uma vez que essa se encontra incorporada nos dispositivos automáticos e dissociada do corpo dos indivíduos ou dos hábitos coletivos. (LÉVY, 1993)

A informática produz o aumento constante da presença de mensagens textuais sonoras e visuais em nossas vidas. A velocidade e a potência da capacidade de registrar, estocar e representar a informação escrita, sonora e visual foram ampliadas

\footnotetext{
${ }^{6}$ Sociedades em que a informática está disseminada.

7 Lévy (1993) classifica a oralidade em primária e secundária. A oralidade primária se refere ao papel da palavra antes que uma sociedade tenha adotado a escrita. A oralidade secundária está relacionada à função da palavra depois que a escrita foi difundida.

${ }^{8}$ Sociedades em que havia o predomínio da escrita.
} 
significativamente. Passamos a ter uma relação mais pessoal e dinâmica com a informação e a interação mais frequente com as fontes, sejam elas pessoas, sejam bancos de dados localizados em qualquer lugar do mundo.

A informática contribuiu, ainda, para que o conhecimento também passasse a ser apreendido por simulação, algo até então inédito, visto que, na sociedade oral, os ritos e as narrativas eram as formas de transmissão do saber, enquanto a teoria explicação, fundação, exposição sistemática - e a interpretação eram as formas de transmissão do saber após o surgimento da escrita. Sobre a diferença entre simulação e teoria, Lévy (1993) afirma:

\begin{abstract}
A teoria, sobretudo em sua versão mais formalizada, é uma forma de apresentação do saber, um modo de comunicação ou mesmo de persuasão. A simulação, pelo contrário, corresponde antes às etapas da atividade intelectual anteriores à exposição racional: a imaginação, a bricolagem mental, as tentativas e erros. (LÉVY, 1993, p. 124)
\end{abstract}

Nesse sentido, enquanto a teoria responde melhor à pergunta "por quê?", a simulação responde melhor à pergunta "como?". O ato de simular situa-se mais próximo dos bastidores da atividade intelectual, diferentemente do que acontecia com a construção de uma teoria, na qual se tomava o cuidado com a produção de enunciados autossuficientes, objetivos e que não dessem margem à interpretações equivocadas. (LÉVY, 1993)

A informática ampliou de forma considerável a velocidade e a capacidade de registrar, preservar e representar a informação escrita, sonora e visual. A todo instante, surgem novos tipos de software, de menor tamanho e com capacidade cada vez maior de armazenar dados. Devido às articulações entre a informática e as telecomunicações, é possível, hoje, por redes de cabo, satélite, fibras etc., o intercâmbio entre pessoas e máquinas a qualquer momento, em qualquer lugar.

O percurso até aqui delineado sinaliza o fato de que há uma mão de duas vias: os seres humanos criam as tecnologias, mas essas condicionam o pensamento humano, num movimento interativo e simultâneo. É, portanto, necessário elucidar de que modo isso acontece para tirar o máximo proveito. 


\title{
2.1 Informática e educação: pontos e contrapontos
}

No final dos anos 1980 e início dos anos 1990, os computadores começaram a ocupar espaço no mundo do trabalho e no mundo do lazer. Pairavam no ar, contudo, dúvidas quanto à inserção do computador nas escolas, o que fez com que aflorassem posições favoráveis e contrárias a respeito da relação entre informática e educação. (BORBA; PENTEADO, 2012)

Em relação à questão econômica, é levantada a bandeira de que o investimento em computadores não deve ser prioritário enquanto as condições da escola e dos professores não forem melhoradas. Esse argumento traz em seu bojo o pressuposto de que o dinheiro investido em computadores e o destinado à melhoria da infraestrutura e das condições de trabalho do professor seria o mesmo.

Com relação a esse argumento, os autores afirmam:

\begin{abstract}
O aumento de salário dos professores depende da vontade política de quem governa e de uma maior valorização da profissão pela sociedade em geral. Se a sociedade, parte de seu projeto, considerasse fundamental que os professores tivessem melhores salários, haveria mais chances de que tal mudança chegasse à esfera dos governos. O que necessita ser enfatizado é que a verba para informatizar as escolas é proveniente, em geral, de fontes dos orçamentos municipais, estaduais e federais diferentes das utilizadas para salário. Por isso, a compra de computadores não pode ser vista como empecilho para a justa reivindicação de aumentos salariais dos professores. (BORBA; PENTEADO, 2012, p. 14)
\end{abstract}

A melhora dos aspectos estruturais da escola e a valorização do professor devem vir acompanhadas de uma valorização da educação como um todo e isso inclui incorporar os recursos existentes na sociedade. Caso contrário, ter-se-á uma escola do século XVIII para alunos do século XXI. (VALENTE, 1993)

Outro problema implícito nesse argumento dos professores, de caráter econômico, é a suposição de que o computador é supérfluo. Ora, segundo Paulo Freire (1996), se ensinar exige respeito aos saberes construídos socialmente pelos educandos e a aceitação do novo, parece não fazer sentido considerar que a informática seja posta à margem das atividades educacionais, afinal os computadores estão cada vez mais presentes na realidade dos alunos. 
Uma posição - essa de natureza pedagógica - contrária ao uso dos computadores se apoia nos riscos de a informática contribuir para que o aluno seja um mero repetidor de tarefas, o que dificultaria seu desenvolvimento cognitivo. Tal argumento é refutado pelo filósofo francês Michel Serres em uma entrevista concedida ao programa Roda Viva da TV Cultura em 1999. Em suas palavras,

\begin{abstract}
Eu tinha um professor... era um homem admirável e que descrevia a maneira pela qual o homem se levantou. Ele estava de quatro e levantou. E ele nos mostrava, ficando de quatro, mostrava que as duas mãos sustentavam o corpo. E quando o corpo se levantou, dizia ele, as mãos perderam a função de sustentar. Perderam a de sustentar, mas adquiriram a função de pegar, portanto, a mão apareceu. Mas, antes, quando estávamos de quatro, a boca tinha a função de pegar, já que as mãos estavam ocupadas. Portanto, a boca perdeu a função de pegar, não é? Mas ganhou a função de falar. E, desde que esse professor me explicou tal fenômeno, tornei-me um homem otimista, porque ouço todo mundo dizer: "Perdemos o humanismo, perdemos os valores, perdemos a memória. Os jovens não têm mais memória, não têm mais imaginação por causa das imagens. Não têm possibilidade de fazer cálculos, porque existe a calculadora". Mas é melhor assim, não é? Porque é justamente quando se perde a função que percebem que perder a sustentação não é nada, já que os pés dão conta. Mas ganhar as mãos nos tornou uma espécie que pode ser pianista ou então cirurgião, prestidigitador. As mãos são um órgão extraordinário, portanto, ganha-se muito mais do que se perde. Perder isso ou aquilo implica ganhar coisas extraordinárias, porque, de certa forma, até o cérebro perdeu algumas coisas e está livre para inventar. E, como historiador de ciências, posso testemunhar isso. É porque no Renascimento perdeu-se a memória da erudição que inventaram as ciências experimentais, porque, ao invés de copiar as ciências em livros, olhava-se apenas a realidade das coisas. Sou otimista por causa disso. (SERRES, 1999)
\end{abstract}

Reconhece-se que o filósofo faz uma crítica a uma suposta perda de memória e de valores por parte dos jovens, devido ao contato com a informática. À luz da analogia com a evolução do homem - de quadrúpede para bípede -, ele revela sua posição em relação à condição humana diante das tecnologias informáticas, reconhecendo que há conquistas e prejuízos com sua inserção.

Nesse jogo de perdas e ganhos, a informática pode tanto motivar e desenvolver alunos autônomos e criativos - ganhos esses cuja importância é indiscutível e que são perseguidos por todos aqueles que creem que a educação deve contribuir para a formação integral dos alunos - quanto colocar em segundo plano a capacidade dos educandos de memorizar algo ou de fazer cálculos.

Na contramão dos que se posicionam contra a integração dos computadores aos ambientes educacionais, estão aqueles que apostam na informática como a 
solução para a motivação e o preparo do jovem para o trabalho. Nesse caso, a motivação seria fruto da presença das cores e do dinamismo, enquanto o preparo para o mercado de trabalho se justificaria devido à importância social dada aos computadores.

Segundo Borba e Penteado (2012), essa não somente é uma visão reducionista das potencialidades da informática como também pode levar a alguns equívocos. Para esses autores, a eventual motivação oriunda do uso da informática pode ser passageira, seja porque um dado software se tornou desestimulante, seja porque a estratégia adotada pelo professor faz do aluno um simples expectador.

A preocupação com a qualificação para o trabalho é justificável e encontra respaldo no Art. º da Lei de Diretrizes e Bases da Educação Nacional (LDB):

\begin{abstract}
A educação, dever da família e do Estado, inspirada nos princípios da liberdade e nos ideais de solidariedade humana, tem por finalidade o pleno desenvolvimento do educando, seu preparo para o exercício da cidadania e sua qualificação para o trabalho. (BRASIL, Lei no 9.394 de 20 de dezembro de 1996)
\end{abstract}

Os mesmos autores citados reconhecem que, em se tratando de conseguir empregos, alguém que possua conhecimentos na área de informática está um passo adiante, porém eles compartilham da ideia de que a educação não deve ser voltada unicamente ao mundo do trabalho e alertam para os riscos dessa posição:

O perigo de se assumir essa posição é que a educação torne-se mais uma instância a ser totalmente privatizada, passando a ter o seu currículo e sua própria organização totalmente subordinados às grandes empresas que ditam o que é adequado para este setor (BORBA \& PENTEADO, 2012, p. 16)

Outro argumento comumente defendido é o de que a escola deve preparar todos para lidar com o computador - introduzindo-o como disciplina curricular -, pois ele está presente em suas vidas. Os partidários desse argumento defendem que os alunos devem estudar o que é um computador, como funciona, sua serventia etc. Valente (1993) se opõe a essa ideia afirmando que:

Primeiro, o computador na educação não significa aprender sobre computadores, mas sim através de computadores. Segundo, existem muitos artefatos que fazem parte da nossa vida cuja habilidade de manuseio não foi adquirida na escola, por exemplo, o telefone, o rádio, a televisão. Somos 
capazes de manuseá-los muito bem e essa habilidade não foi adquirida na escola através de cursos sobre esses equipamentos. (VALENTE, 1993, p. 3)

O cenário esboçado sinaliza que a Informática não é um entrave nem tampouco a solução para os problemas que permeiam a Educação. Nas palavras de Machado (2011)

Não parece mais fazer qualquer sentido a discussão sobre a conveniência de se utilizar computadores na escola. Usar ou não usar já não é a questão. O computador está aí, cada vez mais presente fora da escola, insinuando-se como instrumento básico para muitas das tarefas escolares. A escola pode até fechar os olhos para ele mas estará deixando de lado aspectos significativos da realidade extraescolar, da sociedade como um todo. O que é preciso discutir - e aí o debate encontra-se completamente aberto - é como incorporá-lo ao processo educacional, distinguindo tarefas em que sua utilização é fundamental de outras em que sua contribuição é perfunctória. (MACHADO, 2011, p. 225)

O autor acena para uma mudança de perspectiva em que o âmago das reflexões deve estar voltado para o computador inserido no contexto da sala de aula. Investigar de que forma o computador nesse contexto pode contribuir para o processo de ensino e aprendizagem de Matemática é o objetivo a ser perseguido.

\subsection{O papel do computador no processo de ensino e aprendizagem}

O computador no contexto educacional traz consequências tanto para o processo de aprendizagem dos alunos quanto para a prática pedagógica dos professores. Da mesma forma que o livro didático não deveria ser usado acriticamente, não cabe colocar o computador acima de qualquer suspeita, uma vez que o seu uso pode melhorar uma prática "ruim", mas também pode piorar uma "boa" prática. Para entender de que modo o computador pode ser integrado ao contexto educacional de modo a contribuir para uma aprendizagem significativa, convém examinar as reflexões de alguns estudiosos, como Tikhomirov (1981) e Valente (1999). 


\subsubsection{A perspectiva de Tikhomirov}

Oleg Konstantinovich Tikhomirov (1933-2000) foi um psicólogo russo, professor e chefe do Departamento de Psicologia Geral da Universidade Estatal de Moscou. Em seus estudos sobre a relação entre tecnologia e cognição, Tikhomirov (1981) procura desvelar como o computador interfere na atividade intelectual humana à luz de três teorias: teoria da substituição, teoria da suplementação e teoria da reorganização.

Na teoria da substituição, o papel do computador é o de substituir o ser humano em todas as esferas do trabalho intelectual. Tikhomirov (1981) considera que essa teoria não expressa a relação entre o pensamento humano e o trabalho do computador, pois, embora o computador chegue aos mesmos resultados que o homem na resolução de certos tipos de problemas, os processos por ele usados não correspondem aos usados pelo ser humano.

Já a teoria da suplementação se sustenta na ideia de que o computador se justapõe ao ser humano complementando-o. Dessa forma, computador e ser humano realizam partes de um processo que antes era realizado apenas pelo homem. Segundo Tikhomirov (1981, p. 258 apud JANEGITZ, 2014, p. 23):

\footnotetext{
Dentro da estrutura da teoria da suplementação, as relações entre o funcionamento dos seres humanos e do computador, se combinados dentro de um sistema, são relações das duas partes de um todo - o "processamento da informação". Com a ajuda do computador humanos processam mais informação, mais rápido e, talvez mais corretamente. Acontece um aumento puramente quantitativo em seus recursos. (TIKHOMIROV, 1981, p. 258)
}

Dessa forma, o autor reconhece que, com o auxílio do computador, o ser humano consegue processar mais informação de modo rápido e correto. Em contrapartida, ele argumenta que essa teoria falha por valorizar os aspectos quantitativos em detrimento dos qualitativos do pensamento humano.

Por fim, a teoria da reorganização é aquela segundo a qual o autor acredita que a informática provoca uma transformação na atividade humana, uma vez que o computador é tido como regulador tanto dos processos de criação, busca e armazenamento de informações quanto das relações humanas. Nas palavras do autor (1981, p. 278 apud JANEGITZ, 2014, p. 24): 
Os casos de grande interesse não são aqueles nos quais o computador assume a solução de certos problemas resolvidos anteriormente por humanos, mas aqueles nos quais um problema é resolvido juntamente por humanos e computador, isto é, o próprio sistema "humano-computador". (TIKHOMIROV, 1981, p. 278)

A reorganização do pensamento, segundo Tikhomirov (1981), está associada à geração de um estágio de pensamento qualitativamente diferente em função das novas possibilidades oferecidas pelo computador, pois é do seu uso que os seres humanos poderão adquirir novas habilidades e novas formas de trabalho criativo, difíceis de serem desenvolvidas sem o auxílio da máquina. Diferentemente das teorias da substituição e suplementação, a teoria da reorganização aposta na relação de interdependência entre ser humano e computador para a construção do conhecimento.

Embora sob abordagens diferentes, convém destacar a compatibilidade entre a teoria da reorganização de Tikhomirov (1981) e as considerações feitas por Lévy (1993), já que ambos consideram que há uma moldagem recíproca entre pensamento e tecnologia e que, portanto, é da interação entre seres humanos e tecnologias que o conhecimento é produzido.

Conceber o computador como mediador da atividade humana é certamente o primeiro passo na direção de compreender como ele se insere no contexto educacional e de que forma pode contribuir para o processo de ensino e aprendizagem de Matemática.

\subsubsection{A perspectiva de Valente}

Valente (1999) analisa duas diferentes formas de uso do computador, uma delas na qual o computador é considerado uma "máquina de ensinar" e outra na qual é assumido como uma "máquina para ser ensinada".

Sobre as consequências de conceber o computador como uma "máquina de ensinar", Valente (1999a) alerta que:

O resultado dessa abordagem educacional é um aprendiz passivo, sem capacidade crítica e com uma visão do mundo de acordo com o que foi transmitido. Ele terá muito pouca chance de sobreviver na sociedade do conhecimento em que estamos adentrando. (VALENTE, 1999a, p. 98) 
Em contrapartida, ao considerar o computador uma "máquina para ser ensinada", a construção do conhecimento é colocada em evidência e o aluno é promovido ao papel de protagonista de seu próprio processo de aprendizagem, afinal, é ele, agora, quem passa as informações - valendo-se de conteúdos e estratégias para o computador. Valente (1999a) alerta que, sob esse ponto de vista, a interação do usuário com o computador demanda que o primeiro descreva suas ideias usando uma linguagem de tal modo precisa que o computador possa executá-las; que, após a execução pela máquina, reflita sobre o que foi executado; que realize a depuração da ideia original à luz do resultado alcançado, o que possivelmente o levará a repetir o ciclo descrição - execução - reflexão - depuração.

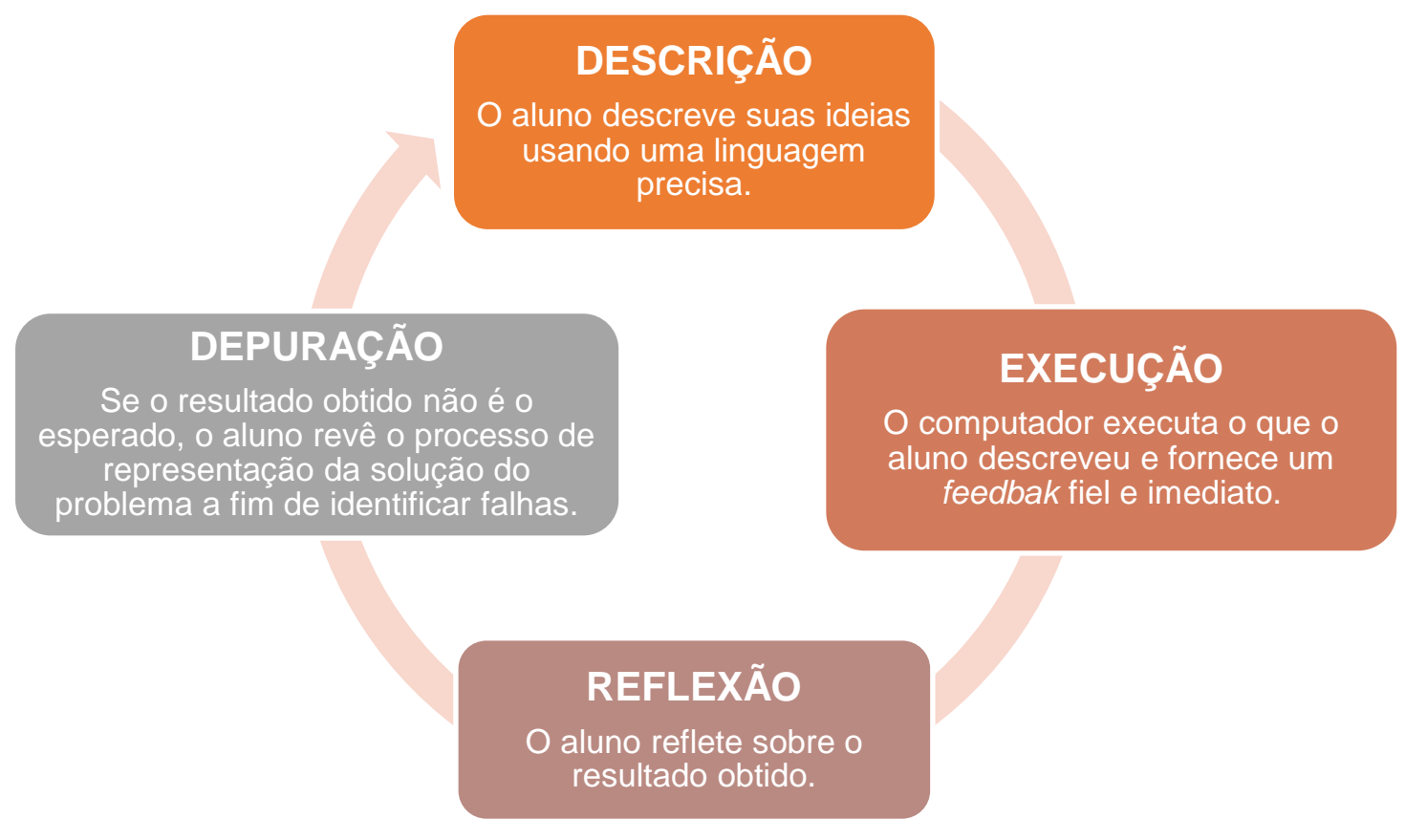

Figura 2: Ciclo descrição - execução - reflexão - depuração,proposto por Valente (1999).

Para entender cada uma das etapas do ciclo, vamos recorrer a um exemplo prático relacionado à atividade de programação: a construção de um triângulo equilátero de lado 100 usando o software SuperLogo $3.0^{9}$. A escolha desse primeiro

\footnotetext{
${ }^{9} \mathrm{~A}$ linguagem de programação Logo foi desenvolvida no Massachusetts Institute of Techology (MIT), sob a direção de Seymour Papert e Marvin Minsky, e teve sua primeira versão lançada em 1968. Encontra-se disponível gratuitamente para download em http://www.nied.unicamp.br/?q=content/super-logo-30. (Acesso em: 01 abr. 2016.)
} 
exemplo justifica-se pelo fato de a inspiração de Valente, ao propor esse ciclo, estar nas experiências de Seymour Papert com a linguagem de programação Logo. Em seguida, apresentaremos mais dois exemplos - esses utilizando o software GeoGebra - com o objetivo de mostrar que o ciclo pode ocorrer em atividades que não são necessariamente de programação.

A figura a seguir exibe a interface inicial do SuperLogo 3.0.

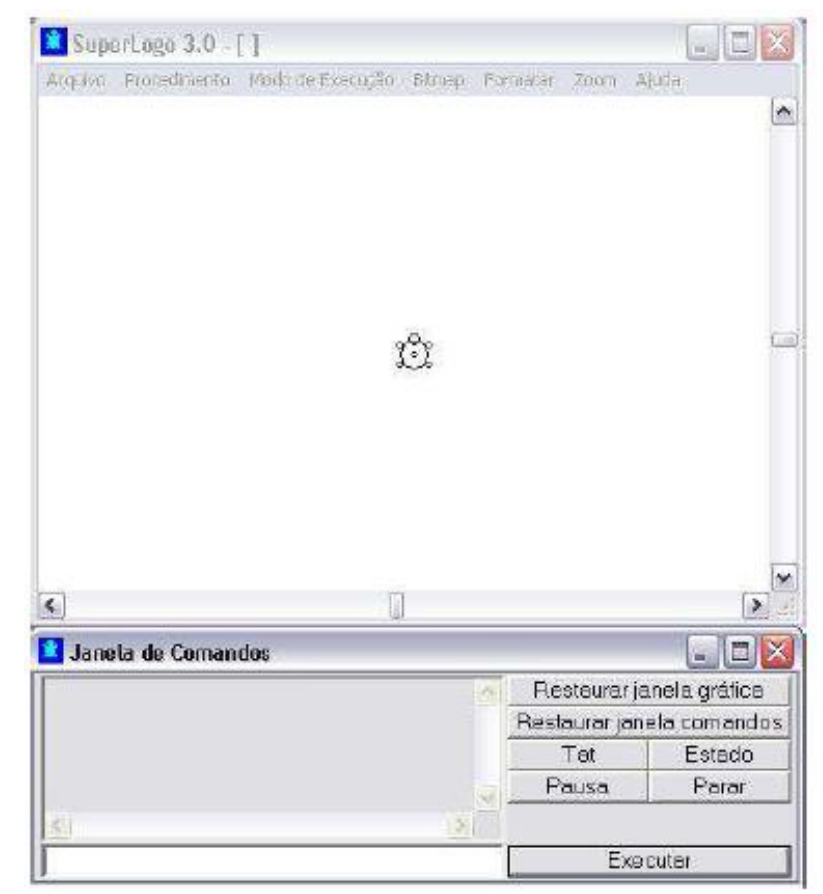

Figura 3: Interface do SuperLogo 3.0.

A interface do SuperLogo 3.0 é constituída de uma janela de comandos e uma janela gráfica principal. No centro da janela gráfica, localiza-se um cursor, imitando uma tartaruga, que realiza os movimentos solicitados pelo usuário.

Os movimentos da "tartaruga", como passos e giros, possibilitam a construção de objetos geométricos, como segmentos de reta e ângulos. Por intermédio do SuperLogo 3.0, é possível construir sequências de comandos - um algoritmo - que determinam um conjunto ordenado, ou sequencial, de ações que produzem uma figura geométrica.

A tabela a seguir mostra os comandos básicos que são empregados para mover a "tartaruga". 
LISTA DE COMANDOS BÁSICOS DO SUPERLOGO 3.0 E SUA DESCRIÇÃO

\begin{tabular}{|l|l|}
\hline \multicolumn{1}{|c|}{ Comandos básicos } & \multicolumn{1}{c|}{ Descrição } \\
\hline pf<números & Move a "tartaruga" para frente de uma distância dada pelo número. \\
\hline pt<número> & Move a "tartaruga" para trás de uma distância dada pelo número. \\
\hline$p d<$ ângulo> & Move a "tartaruga" para a direita de um ângulo em graus dado. \\
\hline$p e<$ ângulo $>$ & Move a "tartaruga" para esquerda de um ângulo em graus dado. \\
\hline Repita $n[<$ comandos $>]$ & Repete $n$ vezes a sequência de comandos contida nos colchetes. \\
\hline
\end{tabular}

Quadro1: Comandos básicos do SuperLogo 3.0.

A construção do triângulo equilátero de lado 100, proposta como exemplo, passa primeiramente por supor o problema resolvido. Tal suposição dá indícios de que conceitos matemáticos devem ser mobilizados e de que comandos devem ser dados à máquina.

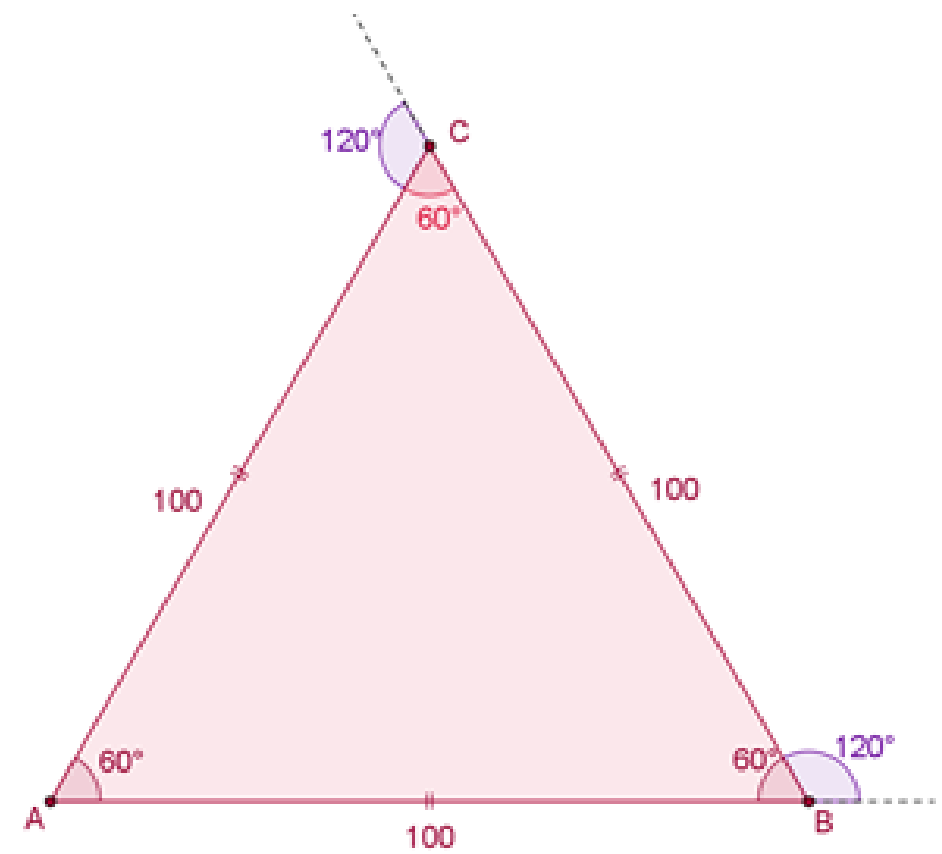

Figura 4: Triângulo equilátero de lado 100.

Após esse estudo preliminar, é preciso fazer a descrição do caminho que a "tartaruga" vai realizar, usando a linguagem de programação (pd 90, pf 100, pe 120, etc.).É nessa etapa que serão mobilizados os conceitos envolvidos e a estratégia empregada na construção da figura. No exemplo em questão, é preciso levar em 
consideração que a "tartaruga" inicialmente está olhando para cima e saber que a soma dos ângulos internos de um triângulo é $180^{\circ}$ e que todo triângulo equilátero é equiangular.

O computador executa a sequência de comandos fornecida. Segundo o autor, a execução "fornece um 'feedback' fiel e imediato, desprovido de qualquer animosidade ou afetividade que possa haver entre o aluno e o computador." (VALENTE, 1999a, p. 91). Dessa forma, o resultado obtido é fruto exclusivamente das ações do aluno. A sequência de imagens a seguir mostra o triângulo sendo construído conforme os comandos fornecidos ao computador.

togo

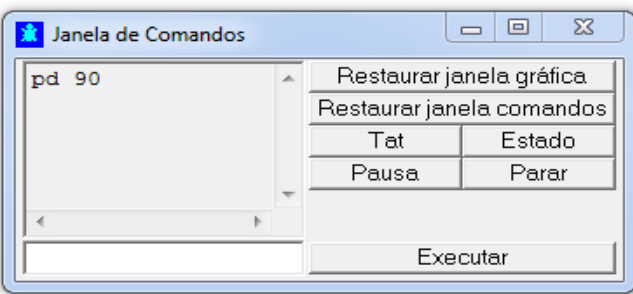

\section{son}
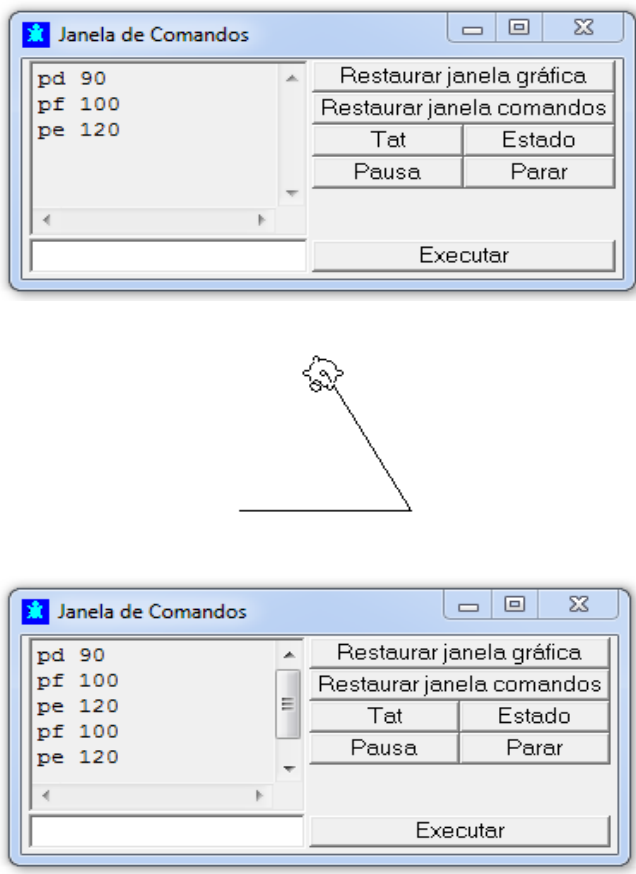
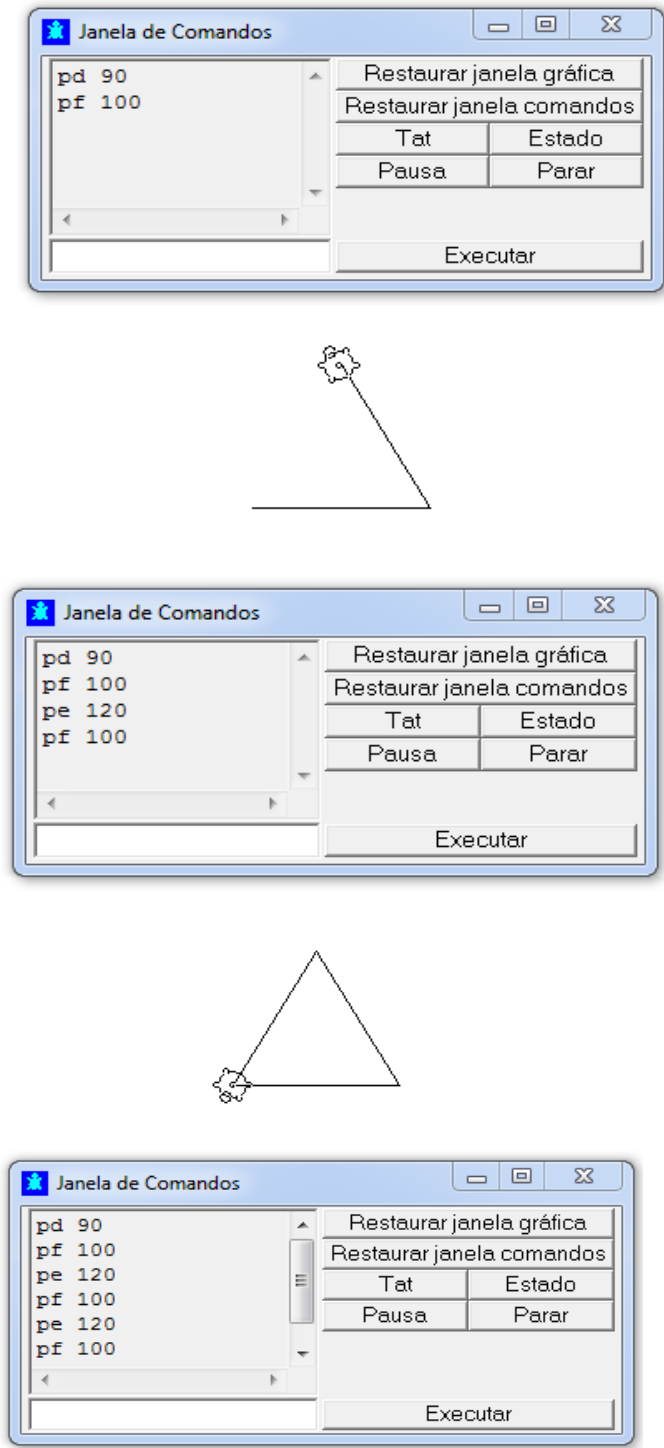

Figura 5: Construção de um triângulo equilátero de lado 100 no SuperLogo 3.0. 
Observando o triângulo sendo gerado e sua forma final, o aluno faz uma reflexão, comparando as etapas da execução e o resultado com o que havia planejado. Nesse ponto, podem ocorrer duas situações: em uma delas, o resultado fornecido é o esperado e a atividade está concluída (conforme mostra a figura 4); na outra, o resultado fornecido pelo computador não corresponde ao esperado, conforme ilustra a figura a seguir.

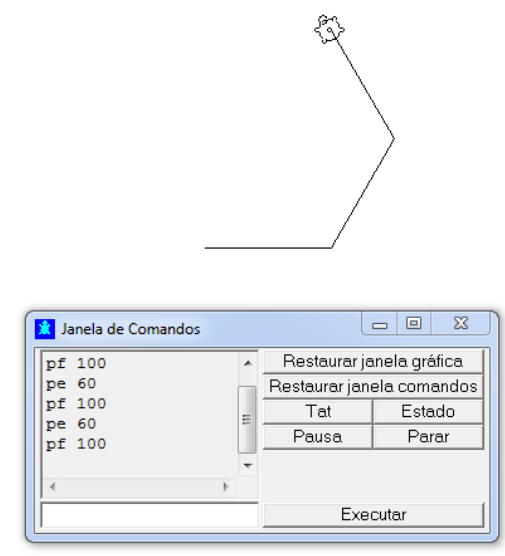

Figura 6: Falha na descrição da construção do triângulo equilátero de lado 100.

Caso isso ocorra, é necessário efetuar a depuração, ou seja, rever a solução do problema. A depuração leva o aluno a repensar a estratégia empregada na resolução, os comandos da linguagem LOGO ou ainda algum conceito envolvido na construção da figura. Reexaminar o que foi feito implica buscar as informações que faltam e refletir sobre os erros cometidos e sobre as formas possíveis de corrigi-los. Sobre essa etapa, Maltempi (2012) diz: A atividade de depuração tem sua origem no erro, e este está intimamente
relacionado com a construção de conhecimento, pois atua como um motor
que desequilibra e leva o aprendiz a procurar conceitos e estratégias para
melhorar o que já conhece. Nessa busca, novas informações são
processadas e agregadas ao conhecimento já existente. Portanto, o
aprendizado se dá através da construção de uma série de teorias transitórias.
Esse processo ocorre via tentativas e erros, no qual o aprendiz parte dos
aspectos já conhecidos da solução do problema e segue construindo suas
próprias teorias. As teorias que não forem adequadas vão sendo descartadas
ou alteradas até se tornarem cada vez mais estáveis. (MALTEMPI, 2012, p.
295)

Dessa forma, Maltempi (2012) considera a depuração uma atividade fundamental para a construção de conhecimentos. A cada nova tentativa de corrigir a 
tarefa executada, uma nova descrição é gerada e o ciclo descrição - execução reflexão - depuração se repete em um novo nível, até que o resultado obtido seja compatível com o esperado.

Valente, ao propor o ciclo descrição - execução - reflexão - depuração, estava fortemente inspirado na linguagem de programação LOGO. Podemos perceber, no entanto, que o ciclo também pode se realizar em atividades que não são de programação. Para exemplificar essa afirmação, serão apresentados dois exemplos de atividades a serem realizadas com o software GeoGebra ${ }^{10}$.

A figura a seguir exibe a interface inicial do GeoGebra.

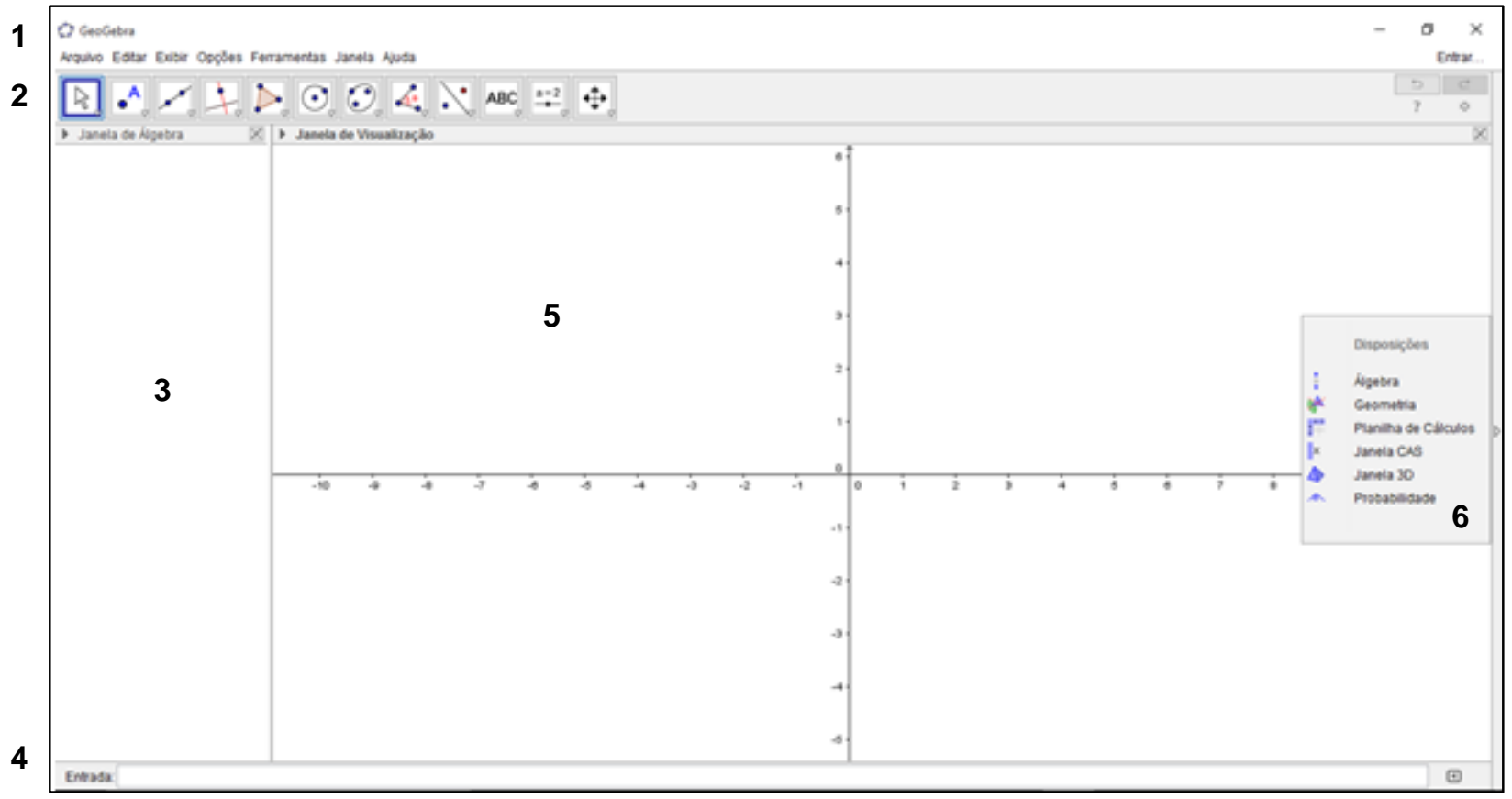

Figura 7: Interface inicial doGeoGebra.

A interface do GeoGebra é constituída de uma Barra de Menus (1), na qual estão disponibilizadas as opções para salvar o projeto em arquivo (.ggb) e para controlar configurações gerais; uma Barra de Ferramentas ${ }^{11}$ (2), na qual se encontram as ferramentas para a construção de pontos, retas, figuras geométricas e para a

10 O GeoGebra é um software de Geometria Dinâmica desenvolvido em 2001 por Markus Hohenwarter da Universidade de Salzburg.

Encontra-se disponível gratuitamente para download em: https://www.geogebra.org/download (Acesso em: 01 abr. 2016.)

${ }^{11}$ Cada ícone dessa barra contém outros ícones que podem ser acessados clicando com o mouse em seu canto inferior direito. 
obtenção de medidas de objetos construídos, dentre outros; uma Janela de Álgebra (3), que é a área em que são exibidas as coordenadas dos pontos, equações, medidas e outros atributos dos objetos construídos; Entrada (4), na qual são digitados os comandos; Janela de Visualização (5), que é a área de visualização gráfica de objetos que possuam representação geométrica e que podem ser desenhados ao se selecionar, com o mouse, ícones da Barra de Ferramentas ou por meio de comandos digitados na Entrada. O GeoGebra também oferece diferentes Disposições (6) que permitem alterar a interface padrão de acordo com a tarefa a ser realizada. Dois exemplos são exibidos a seguir:

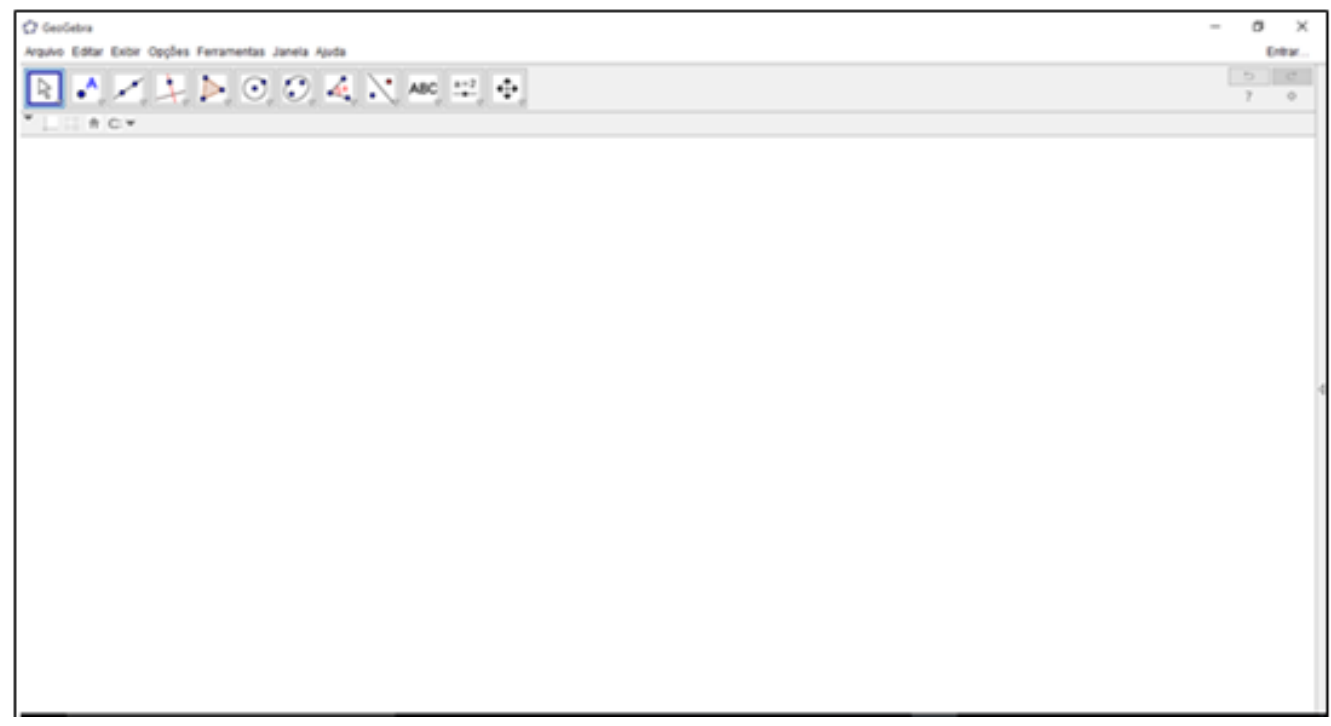

Figura 8: Disposição "Geometria".

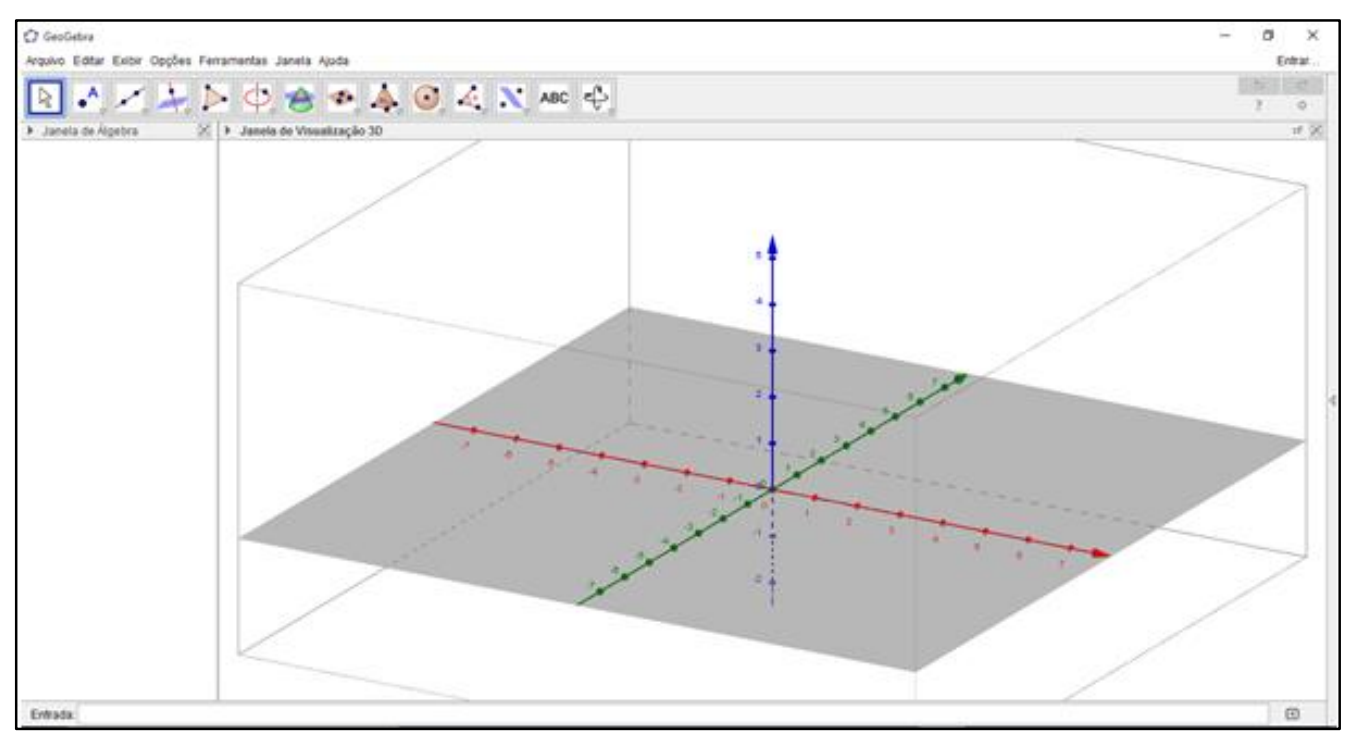

Figura 9: Disposição "Janela 3D”. 
Exemplo 1: Construção de um triângulo $A B C$ com $A B=8 \mathrm{u}, B C=6 \mathrm{u}$ e $A C=4 \mathrm{u}$, em que u é uma unidade de comprimento.

Para realizar a construção, convém inicialmente, com o auxílio de lápis e papel, supor o problema resolvido:

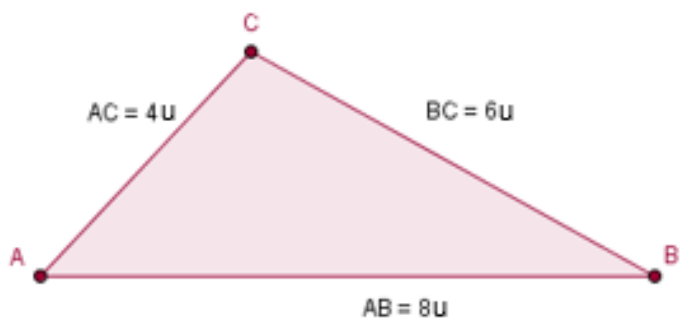

Figura 10: $O$ problema resolvido: triângulo $A B C$, com $A B=8 \mathrm{u}, B C=6 \mathrm{u}$ e $A C=4 \mathrm{u}$.

Em seguida, é necessário explorar a figura inicial de modo a extrair informações que possam auxiliar na construção do triângulo:

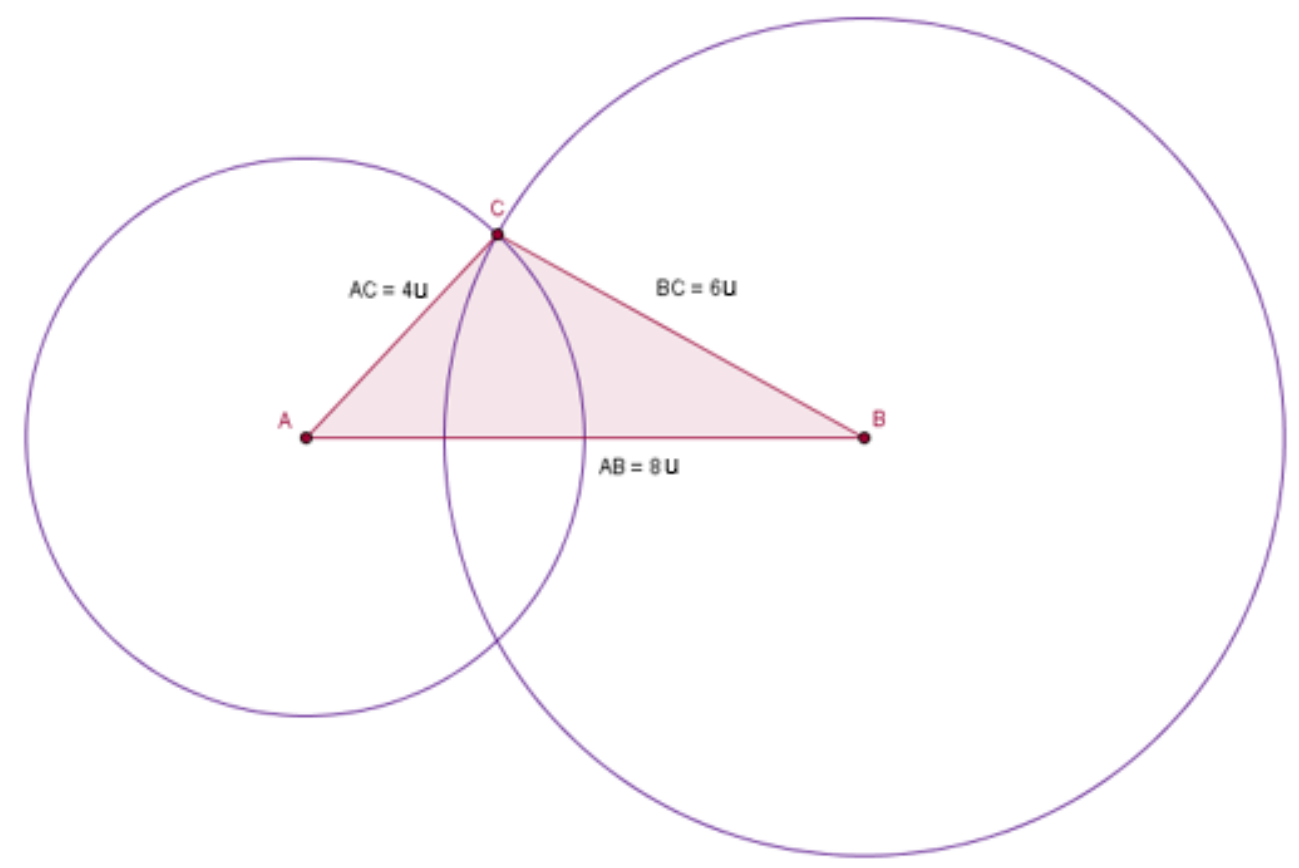

Figura 11: Exploração da Figura 10.

A partir da exploração da figura inicial, pode-se perceber, por exemplo, que o vértice $C$ do triângulo pertence à circunferência de centro $A$ e raio de medida $4 \mathrm{u}$ e também à circunferência de centro em $B$ e raio de medida 6 u.

Com isso, podemos construir o triângulo pedido, seguindo os seguintes passos: 
1) Construção - utilizando a ferramenta "Segmento com Comprimento Fixo"de $\overline{A B}$, com $A B=8 \mathrm{u}$.

2) Construção da circunferência de centro $A$ e raio de medida $4 u$ e da circunferência de centro $B$ e raio de medida $6 u$. Para fazer essas construções, pode-se utilizar a ferramenta "Círculo dados Centro e Raio".

3) Determinação do ponto de intersecção das circunferências construídas anteriormente (vértice $C$ ). Isso pode ser feito utilizando a ferramenta "Intersecção de Dois Objetos".

4) Construção - utilizando, por exemplo, a ferramenta "Polígono" - do triângulo com vértices nos pontos $A, B$ e $C$.

A descrição, nesse caso, engloba a etapa de supor o problema resolvido quando serão mobilizados os conceitos de geometria envolvidos na construção do triângulo com as medidas especificadas - e a seleção das ferramentas disponíveis na barra.

Ao selecionar as ferramentas, o computador gera, na Janela de Visualização, um resultado (feedback) correspondente à sua ação. A sequência de imagens a seguir mostra os resultados fornecidos pelo software de acordo com as ferramentas selecionadas pelo aluno:

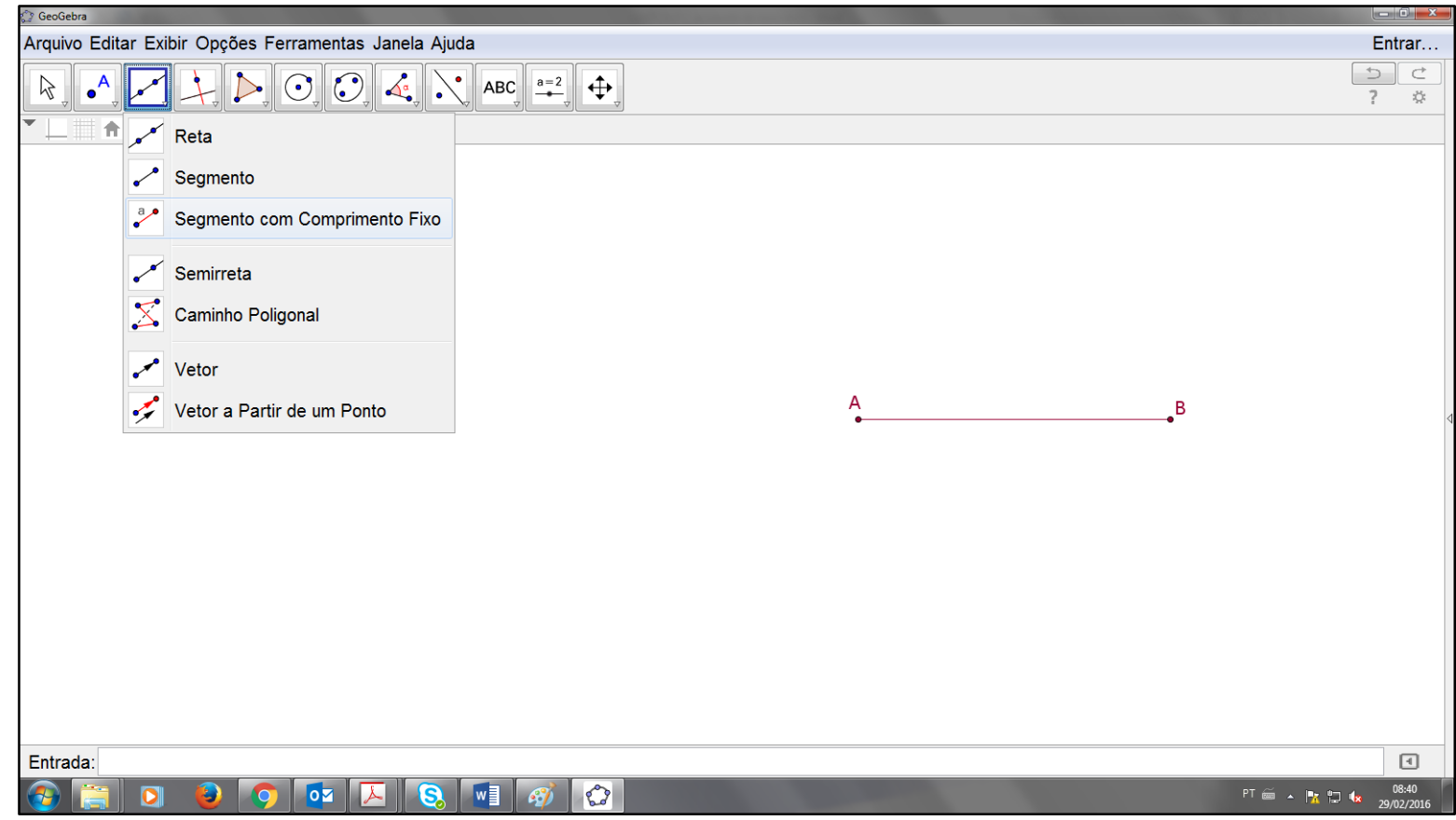

Figura 12: $\overline{A B} \operatorname{com} A B=8 \mathrm{u}$. 


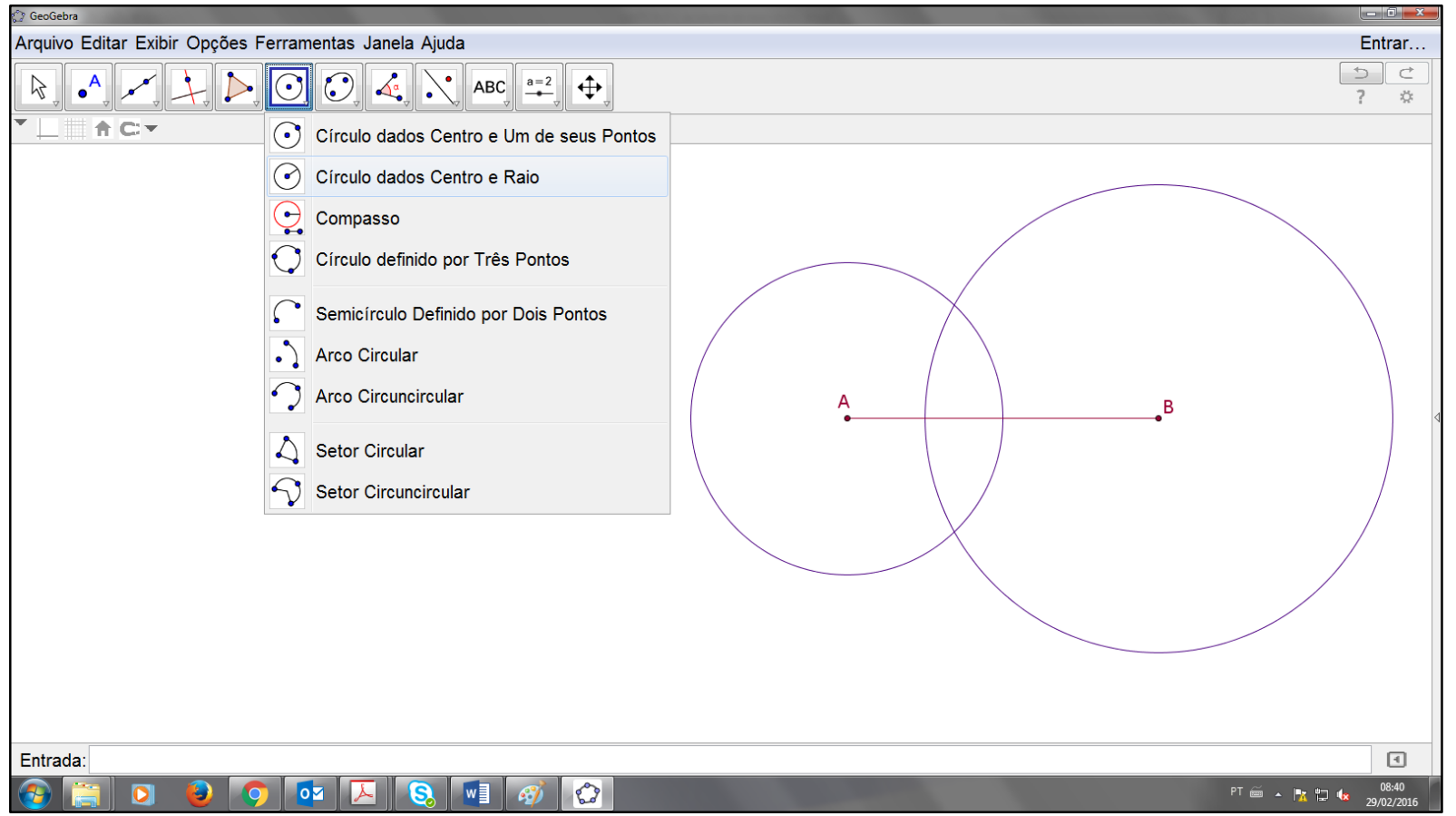

Figura 13: Circunferência de centro $A$ e raio de medida 4 u e circunferência de centro $B$ e raio de medida $6 u$.

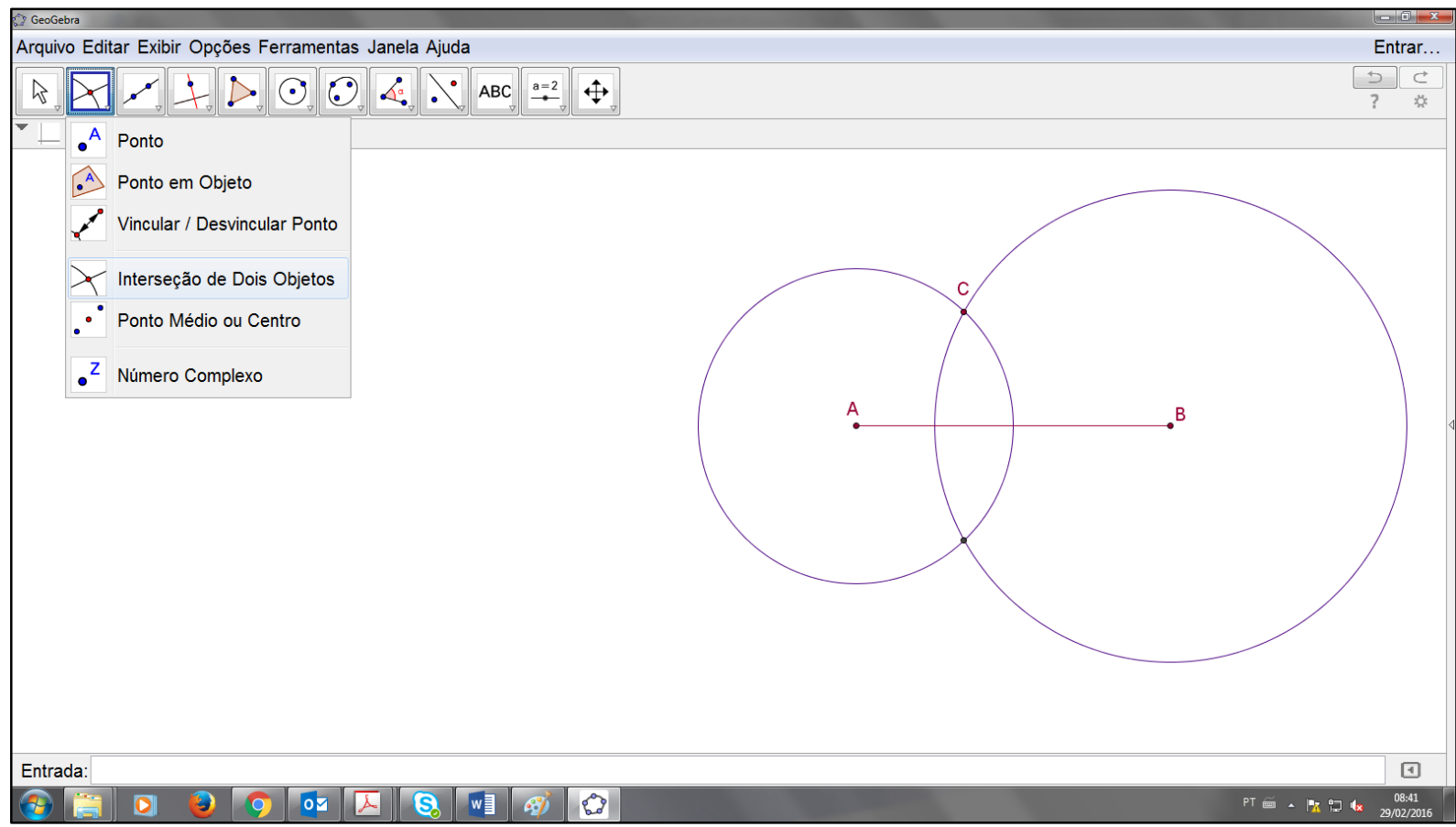

Figura 14: $O$ ponto $C$. 


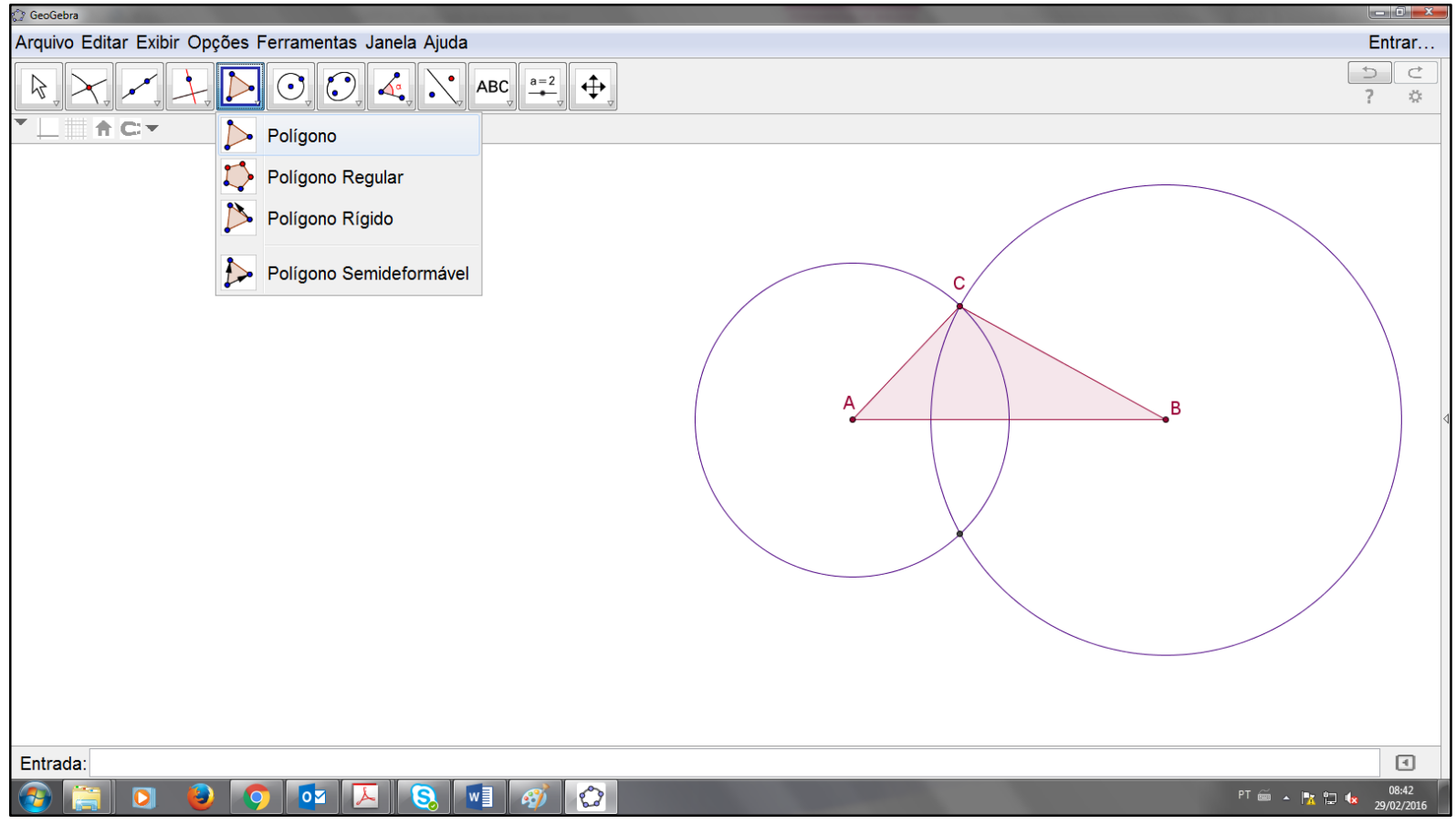

Figura 15: O triângulo $A B C$, com $A B=8 \mathrm{u}, B C=6 \mathrm{u}$ e $A C=4 \mathrm{u}$.

O GeoGebra oferece a possibilidade de arrastar o triângulo construído e observar, por exemplo, se as medidas de seus lados permanecem inalteradas. Em virtude disso, pode-se dizer que o software estimula a reflexão, pois leva o aluno a investigar. Nessa etapa, será possível perceber, por exemplo, que construir uma figura não se resume a chegar à imagem desejada dela, ou seja, é possível concluir que há uma distinção entre desenho e construção. Sobre essa distinção, Borba, Silva e Gadanidis (2014) comentam:

\footnotetext{
Em uma construção, a figura sempre preserva suas propriedades fundamentais quando um dos elementos "móveis" que a compõem é arrastado. Se arrastarmos uma figura e ela não mantiver suas propriedades fundamentais, a figura é apenas um desenho. (BORBA, SILVA e GADANIDIS, 2014, p. 24)
}

Por fim, caso a construção não esteja correta $^{12}$, inicia-se o processo de depuração, que é quando os conceitos e a estratégia empregada na construção da figura são revistos.

\footnotetext{
12 Um erro bastante comum e que, consequentemente, pode dar início ao processo de depuração é construir o triângulo "a olho".
} 
Exemplo 2: Construção do gráfico da função quadrática $f(x)=-\left(\frac{x}{2}\right)^{2}+\frac{x}{2}+2$.

Também é possível verificar que o ciclo descrição - execução - reflexão depuração se realiza por meio dessa atividade.

A descrição se resume em digitar a lei da função na Entrada ${ }^{13}$ :

$$
f(x)=-(x / 2)^{\wedge} 2+(x / 2)+2 \text { ou } f(x)=-(x / 2)^{\wedge} 2+x / 2+2
$$

A execução ocorre quando, após inserir a lei da função, dá-se o "Enter". Dessa forma, o gráfico gerado pelo software é o resultado da expressão da função fornecida.

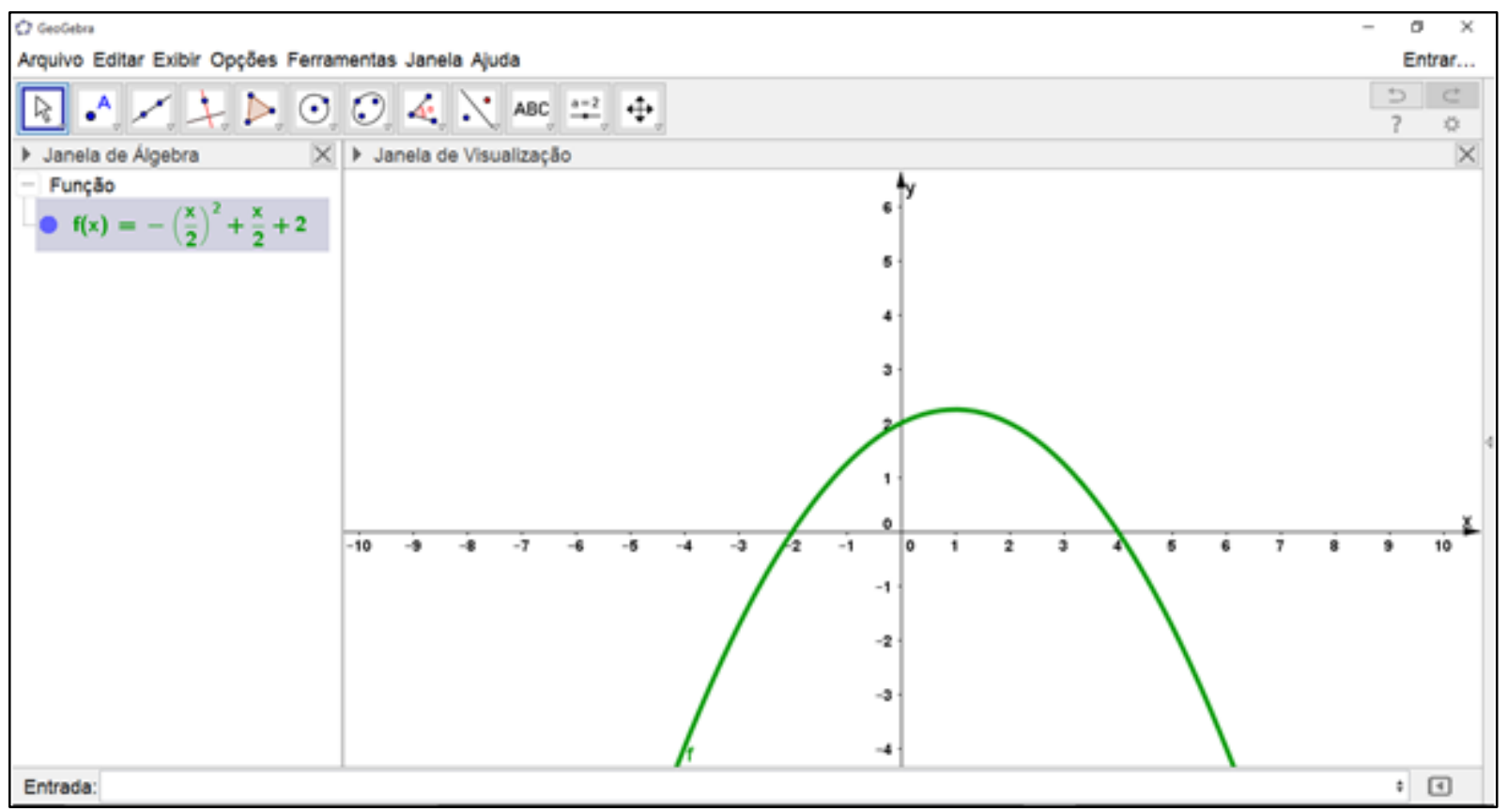

Figura 16: Gráfico da função $f(x)=-\left(\frac{x}{2}\right)^{2}+\frac{x}{2}+2$.

A reflexão precisa ser estimulada pelo professor, que pode solicitar justificativas para algumas características do gráfico, como:

- O gráfico da função tem concavidade voltada para baixo;

- A função possui duas raízes reais e distintas;

- O valor máximo da função é $\frac{9}{4}$;

- O gráfico da função intercepta o eixo das ordenadas no ponto $(0,2)$.

- O ponto $(2,2)$ pertence ao gráfico da função.

${ }^{13}$ Foi utilizada a sintaxe do GeoGebra. 
Por fim, caso o gráfico gerado não atenda a alguma das características acima, a atividade de depuração é iniciada ${ }^{14}$.

É importante destacar que, nos exemplos anteriores, a descrição, execução, reflexão e depuração são processos que estão imbricados e que não ocorrem necessariamente na ordem descrita. $O$ valor do ciclo está na natureza dos processos e não na ordem segundo a qual eles podem ocorrer.

Vale salientar que, às ideias de Valente, subjaz a preocupação de que sejam proporcionadas aos alunos experiências nas quais eles possam resolver problemas que Ihes sejam significativos e por meio dos quais determinados conceitos e fatos possam ser empregados e compreendidos. A atividade de programação pode, sem dúvida, levar os alunos a vivenciar tais experiências, porém as atividades descritas mostram que esse não é o único caminho. Conceber o computador como um aliado dos alunos na resolução de problemas traz à tona, também, o fato de que o seu uso não deve visar somente a realização de tarefas de maneira mais rápida e "misteriosa", quase "mágica" para o aluno.

As concepções de Valente (1999a) aliadas às de Tikhomirov (1981) convergem para o fato de que o papel do computador seria o de auxiliar a construção do conhecimento, propiciando aos alunos a oportunidade de serem participantes ativos no processo de aprendizagem, tendo controle e responsabilidade sobre ele. Em outras palavras, o papel do computador seria o de provocar nos alunos uma mudança de postura, contribuindo para que deixem de ser meros receptores de informação e passem a mobilizar suas capacidades cognitivas, de modo que a aprendizagem seja efetiva.

\footnotetext{
14 Pode ocorrer de os alunos perceberem que, ao digitar a lei da função, não inseriram os parênteses necessários, fazendo que o software gere o gráfico da função $g(x)=-\frac{x^{2}}{2}+\frac{x}{2}+2$.
} 


\section{Capítulo 3}

\section{$\mathrm{Na}$ busca da construção de um conhecimento matemático significativo}

Assumir uma postura investigativa e estabelecer conjecturas são atitudes que podem ser desenvolvidas pelos alunos ao interagir com o computador, desde que esse seja encarado como um mediador da atividade humana.

Além disso, trabalhar temas de Matemática com base em contextos significativos para os alunos pode ser uma postura salutar quando se pretende que eles venham conhecer determinados objetos matemáticos. A clareza de que os objetos matemáticos não são acessíveis por nenhum dos sentidos - tato, visão, olfato, audição e paladar - torna necessário perceber a importância das representações semióticas. Nesse sentido, a teoria de Raymond Duval constitui um referencial fundamental quando se procura construir conhecimento de maneira significativa.

\subsection{Registros de representação semiótica}

Nas ciências, sobretudo as experimentais, pode-se apelar à realidade concreta para compreender os objetos envolvidos em seus estudos. Um biólogo que se propõe, por exemplo, a estudar uma determinada planta tem a oportunidade de recolher exemplares em seu habitat e, no laboratório, observá-los, tocá-los, cheirá-los e até mesmo realizar experimentos mais detalhados na busca de identificação de suas propriedades ou no entendimento de sua composição. Um físico ou um químico, em geral, podem também se apoiar na realidade concreta, tanto para formular hipóteses, como para verificar a validade de uma teoria. Já a Matemática, diferentemente dessas ciências, lida com objetos que não são perceptíveis aos sentidos, ou seja, que existem apenas no mundo das ideias. A respeito dessa característica, D'Amore (2005) afirma: "cada objeto matemático possui referências a 'não objetos'; assim sendo, a conceitualização não é e não pode estar baseada em significados que se apoiam na realidade concreta [...]" (D'AMORE, 2005, p. 48) 
Dessa forma, os objetos matemáticos não encontram suporte na realidade para serem estudados e consequentemente compreendidos e é, nesse âmbito, que as representações desses objetos se fazem necessárias e imprescindíveis. Aliás, o fato de carecer de representações, é outro aspecto que D'Amore (2005) destaca, pois:

cada conceito matemático necessita de representações, uma vez que não existem "objetos" 15 para serem exibidos em seu lugar ou para evocá-lo; assim, a conceitualização deve necessariamente passar por registros representativos que, por diferentes motivos, sobretudo se forem registros de caráter linguístico, não podem ser unívocos [...] (D'AMORE, 2005, p. 48)

O filósofo e psicólogo francês, Raymond Duval, propôs um modelo de funcionamento cognitivo do pensamento, pautado na mudança de registros de representação semiótica ${ }^{16}$. Segundo ele, "não há noesis sem semiosis; é a semiosis que determina as condições de possibilidade e de exercício da noesis". (DUVAL, 2009, p. 17, grifo do autor)

A noesis se refere aos atos cognitivos como a apreensão conceitual de um objeto, a discriminação de uma diferença ou a compreensão de uma inferência. Já a semiosis está relacionada à apreensão ou à produção de uma representação semiótica. As representações semióticas são um meio para a apreensão conceitual dos objetos matemáticos.

No caso específico da Matemática, Duval alerta para a existência de um paradoxo aparente, que ele denomina por paradoxo cognitivo do pensamento matemático ${ }^{17}$. Em suas palavras:

[...] de um lado, a apreensão dos objetos matemáticos só pode ser uma apreensão conceitual e, por outro lado, somente por meio de representações semióticas é possível uma atividade sobre objetos matemáticos. Esse paradoxo pode constituir um verdadeiro círculo vicioso para a aprendizagem.

\footnotetext{
15 "Objeto" aqui é entendido no sentido de "objeto real" ou de "coisa".

${ }^{16}$ Segundo o dicionário Aurélio, semiótica é "a ciência dos modos de produção, de funcionamento e de recepção dos diferentes sistemas de sinais de comunicação entre indivíduos ou coletividades".

17 Segundo Goldstein (2008): "Os paradoxos, no sentido técnico, são aquelas catástrofes da razão pelas quais a mente é compelida, pela própria lógica, a tirar conclusões contraditórias. Muitos são do tipo auto-referencial; os problemas surgem porque certos itens linguísticos - uma descrição, uma sentença - potencialmente se referem a si próprios. O mais antigo desses paradoxos é conhecido como 'paradoxo do mentiroso', que remonta aos gregos antigos. Ele gira em torno da sentença autoreferencial: 'Esta sentença é falsa'. Essa sentença deve ser, como todas as sentenças, verdadeira ou falsa. Mas se for verdadeira, então será falsa, pois é isso que ela diz, e se for falsa, então será verdadeira, já que, novamente, é isso que ela diz. Deve, portanto, ser verdadeira e falsa, e isso é um grave problema. A mente entra em parafuso". (GOLDSTEIN, 2008, p. $41-42$, grifo da autora)
} 
Como sujeitos, em fase de aprendizagem, poderiam deixar de confundir os objetos matemáticos com suas representações semióticas se eles apenas podem estabelecer relações com as representações semióticas? A impossibilidade de um acesso direto aos objetos matemáticos, a não ser por meio de representação semiótica, torna a confusão praticamente inevitável. $\mathrm{E}$, ao contrário, como podem esses indivíduos adquirir o domínio dos tratamentos matemáticos, necessariamente ligados às representações semióticas, se ainda não possuem uma apreensão conceitual dos objetos representados? Esse paradoxo é ainda mais forte ao se identificar atividade matemática e atividade conceitual e ao considerar as representações semióticas como secundárias ou extrínsecas. (DUVAL,1993 apud D'AMORE, 2005, pp. 51, 52)

Assim, se por um lado, o autor percebe a necessidade de apreensão conceitual dos objetos matemáticos, por outro, entende que eles somente se tornam acessíveis por meio das representações semióticas. Alerta também para o fato de como ser possível lidar com as representações de um objeto sem conhecê-lo.

Dessa forma, para ocorrer compreensão em Matemática é importante distinguir entre os objetos matemáticos e as representações que se fazem deles. Nesse âmbito, D’Amore (2005) alerta para a importância de que o discente e, principalmente, o docente entendam como se processa a aprendizagem na disciplina, pois:

[...] de um lado, o estudante não sabe que está aprendendo signos que estão no lugar de conceitos e que deveria estar aprendendo conceitos; de outro lado, se o professor nunca refletiu sobre o assunto, acreditará que o estudante está aprendendo conceitos, enquanto ele está, na realidade, "aprendendo" apenas a utilizar signos. (D'AMORE, 2005, p. 52)

Na Matemática estão presentes pelo menos quatro tipos diferentes de registros: registro da língua natural (argumentações e deduções verbais), registro figural (por exemplo, figuras geométricas planas ou que representam objetos geométricos), registro de sistemas de escrita e cálculo (numéricos, algébricos e simbólicos) e registro gráfico (sistema de coordenadas). Segundo Duval (2009) cada um desses registros apresenta significados particulares e que permitem caracterizar de diferentes maneiras o objeto estudado. 


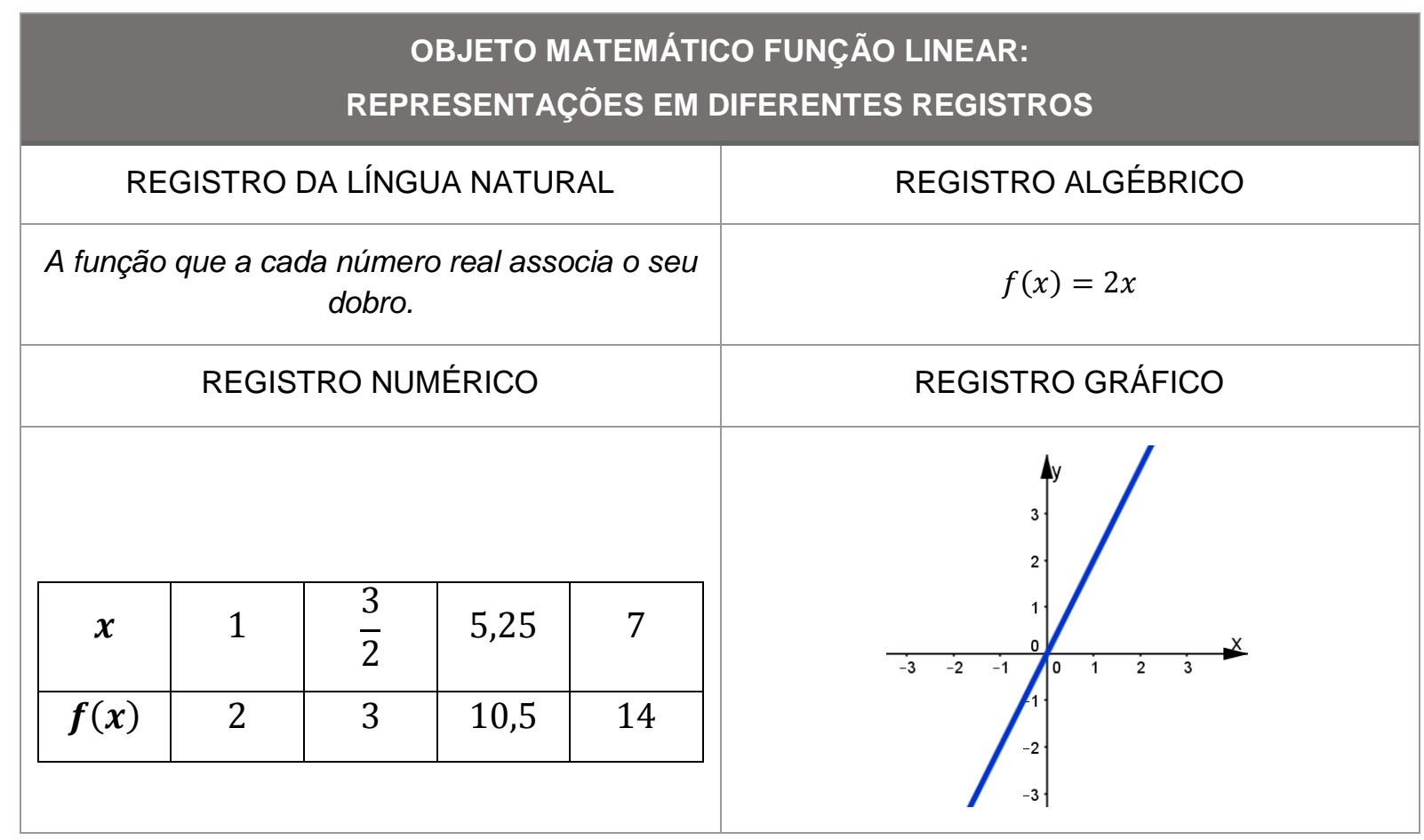

Quadro 2: Objeto matemático: uma função linear - representações em diferentes registros.

OBJETO MATEMÁTICO CIRCUNFERÊNCIA DE CENTRO NUM PONTO E RAIO DADO: REPRESENT AÇÕES EM DIFERENTES REGISTROS

\begin{tabular}{|c|c|c|}
\hline $\begin{array}{c}\text { REGISTRO DA LÍNGUA } \\
\text { NATURAL }\end{array}$ & REGISTRO ALGÉBRICO & REGISTRO GRÁFICO \\
\hline $\begin{array}{c}\text { Conjunto dos pontos do plano } \\
\text { que distam duas unidades da } \\
\text { origem. }\end{array}$ & $x^{2}+y^{2}=4$ \\
\hline
\end{tabular}

Quadro 3: Objeto matemático circunferência de centro num ponto e raio dado - representações em diferentes registros.

Ainda, segundo Duval, é a mobilização, por parte dos alunos, dos diferentes registros nos quais são feitas as representações de um mesmo objeto matemático, 
que poderá contribuir para a apropriação do referido objeto, ao ficarem claras as diversas características que aparecem nas representações. Mais ainda, cada representação fornece diferentes caracterizações do objeto representado. Dessa forma, a confusão entre representante e representado é evitada e os alunos passam a distinguir o objeto das suas diferentes representações.

Na teoria dos registros de representação semiótica, proposta por esse autor, são importantes os conceitos de tratamento e de conversão.

Os tratamentos dizem respeito às transformações efetuadas no interior de um mesmo registro de representação. Nas palavras do autor,

\begin{abstract}
Um tratamento é uma transformação de representação interna a um registro de representação [...]. O cálculo é um tratamento interno ao registro de uma escritura simbólica de algarismos e de letras: ele substitui novas expressões em expressões dadas no mesmo registro de escritura dos números. [...] A paráfrase é uma transformação interna ao registro do discurso na língua natural: ela "reformula" um enunciado dado em outro seja para substituí-lo seja para explicá-lo. A anamorphose pode também ser considerada como uma transformação interna a um registro, aquele das figuras, embora não tenha mais aqui conservação da situação apresentada. (DUVAL, 2009, p. 57, grifo do autor)
\end{abstract}

Assim, um tratamento mobiliza apenas um registro de representação, o que segundo o autor, permite apenas uma compreensão parcial do objeto matemático, justamente por não contemplar todas suas caracterizações. Existem ainda, regras de tratamento próprias a cada registro e sua natureza e número variam consideravelmente de um registro a outro.

A conversão se refere à uma transformação entre um registro de representação e outro. Nas palavras do filósofo,

\begin{abstract}
A conversão é então uma transformação externa em relação ao registro da representação de partida. A ilustração é a colocação em correspondência de uma palavra, de uma frase, ou de um enunciado com uma figura ou com um de seus elementos. A passagem inversa, da imagem a um texto, pode ser uma descrição ou uma interpretação. A colocação em equação dos dados de um enunciado do problema é a conversão de diferentes expressões linguísticas de relações em outras expressões dessas relações no registro de uma escritura simbólica. (DUVAL, 2009, p.59)
\end{abstract}

Sobre a diferença entre tratamento e conversão Damm (1999) afirma: "O tratamento ocorre internamente ao registro, já a conversão se dá entre os registros, 
ou seja, é exterior ao registro de partida. A conversão exige do sujeito o estabelecimento da diferença entre significado e significante." (DAMM, 1999, p. 147). A operação de conversão é, em geral, mais complexa que a de tratamento, pois exige certos procedimentos metodológicos e o estabelecimento de relações entre elementos das unidades significantes ${ }^{18}$ em cada registro.

Ora, se as dificuldades apresentadas pelos alunos em Matemática, segundo D'Amore (2005), se assentam sobre o fato de que os mesmos possuem o domínio isolado de uma determinada representação e o tratamento específico que a mesma requer, a conversão se configura no primeiro passo na direção de capacitar os alunos a articular outras representações do mesmo objeto para que consigam apreendê-lo.

Duval (2009) afirma que na escola é dada mais importância ao tratamento do que a conversão, ou seja, privilegia-se a forma mais que o conteúdo. Segundo o autor isso é um equívoco, uma vez que, é na conversão que mecanismos subjacentes à compreensão serão desvelados. Em consonância com essa ideia D'Amore enfatiza que: “Aquilo que se denomina 'conceitualização' começa somente quando se coloca em ação, mesmo que apenas num esboço, a coordenação de dois distintos registros de representação" (D’AMORE, 2005, p. 61)

Uma conversão pode ser, segundo Duval (2009), congruente ou nãocongruente. De modo geral, uma conversão é considerada congruente quando o registro de chegada deixa transparecer o registro de partida - em conversões desse tipo há uma correspondência biunívoca entre as unidades significantes de ambos os registros. Por outro lado, quando o registro de chegada pouco lembra o registro de partida temos uma conversão não congruente - em conversões desse tipo não há uma correspondência biunívoca entre as unidades significantes de cada registro. $O$ quadro a seguir ilustra, através de exemplos propostos pelo próprio autor, a diferença entre esses dois tipos de conversão:

\footnotetext{
${ }^{18}$ Que se destacam no "léxico" de um registro.
} 


\section{EXEMPLOS DE CONVERSÃO CONGRUENTE E NÃO - CONGRUENTE}

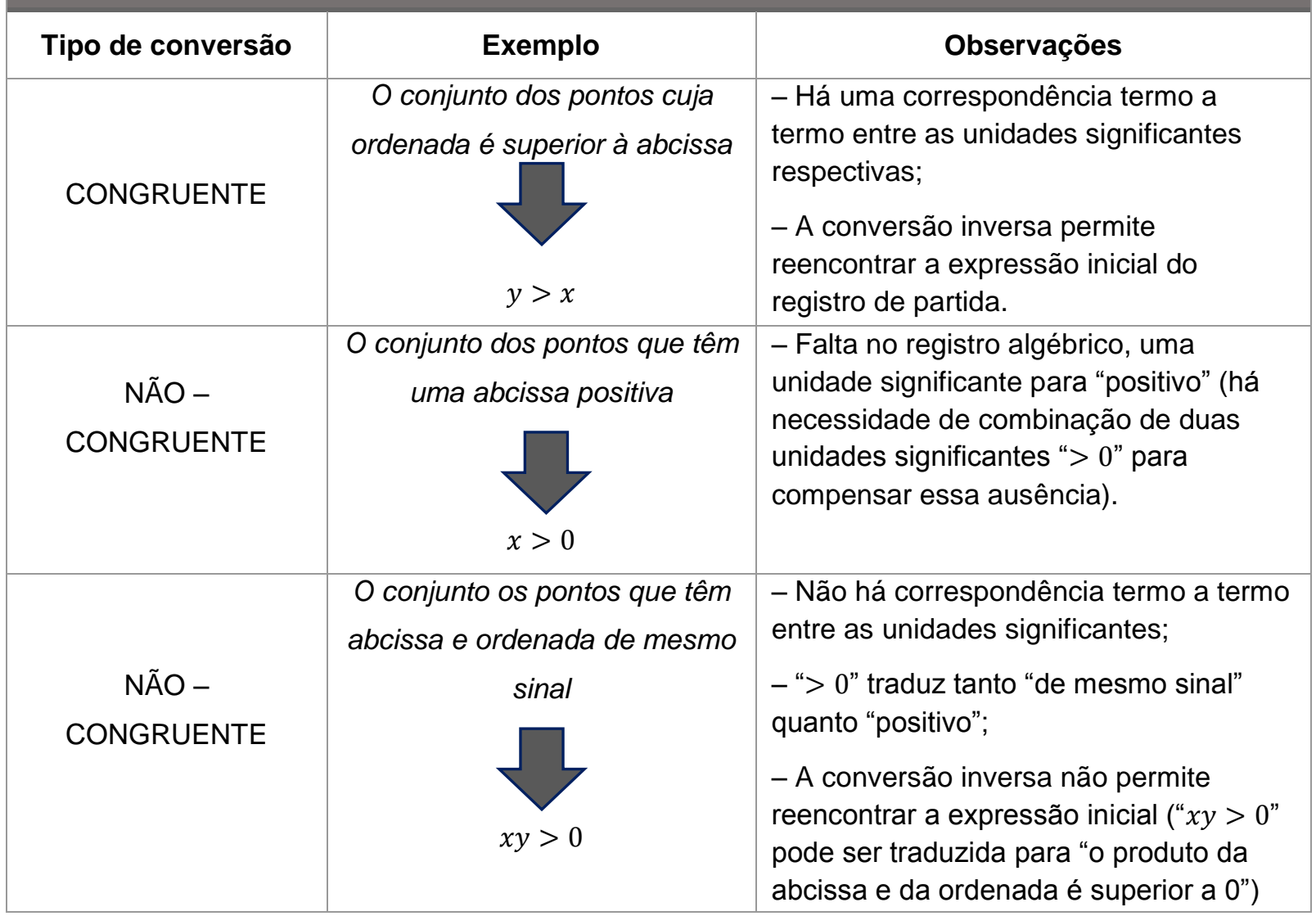

Quadro 4: Exemplos de conversão congruente e não congruente propostos por DUVAL (2009).

Por meio de observações no trabalho em classe, Duval (2009) infere que o fracasso ou sucesso dos alunos na atividade cognitiva de conversão estão atrelados ao tipo de congruência, ao desconhecimento de um dos registros e também ao sentido em que é realizada a conversão. Sobre esse último aspecto ele afirma, por exemplo, ao se referir ao ensino de funções, que

[...] quando a conversão se efetua no sentido escritura algébrica de uma equação $\rightarrow$ gráfico, nenhuma dificuldade específica parece surgir. Mas, tudo muda quando é preciso tomar a conversão inversa, mesmo depois de um ensino sobre as funções lineares. É que, na verdade, as unidades significantes do gráfico (reta, curva, ...) não são, de modo algum, determinadas em relação aos pontos encontrados, não importando qual fundo milimetrado. (DUVAL, 2009, p. 78, grifo do autor)

Apesar da importância da atividade de conversão, o aluno pode passar de um registro a outro, mas não estabelecer relações entre eles e daí se faz importante que haja a coordenação entre esses registros. A coordenação implica em compreender que as representações nos vários registros dizem respeito ao mesmo objeto 
matemático e que podem mesmo se complementar no sentido de que uma representação num registro pode expressar características ou propriedades do objeto matemático que não são expressas com clareza em outra num registro diferente. Segundo Duval,

[...] a atividade conceitual implica a coordenação dos registros de representação. É preciso que um sujeito seja capaz de atingir o estado da coordenação de representações semioticamente heterogêneas, para que ele possa discriminar o representante e o representado ou a representação e o conteúdo conceitual que essa representação exprime, instancia ou ilustra. (DUVAL, 2009, p. 82)

Dessa forma, segundo o autor, é a coordenação das várias representações sobre um objeto de estudo que possibilita a construção do conhecimento sobre esse objeto ou a apreensão do saber.

\subsection{Interdisciplinaridade ${ }^{19}$ e contextualização}

O mundo encontra-se em constantes e aceleradas mudanças. Exemplo disso, é a conexão de pessoas de diferentes partes do mundo em questão de segundos, graças ao progresso em geral e, especificamente à Informática.

Para conviver com essas vicissitudes, é preciso integrar as diversas concepções e realidades, o que acaba por impor à escola o desafio de superar a fragmentação excessiva das disciplinas. Segundo Machado,

[...] parece cada vez mais difícil o enquadramento de fenômenos que ocorrem fora da escola no âmbito de uma única disciplina. Hoje, a Física e a Química esmiúçam a estrutura da matéria, a entropia é um conceito fundamental na Termodinâmica, na Biologia e na Matemática da Comunicação, a Língua e a Matemática entrelaçam-se nos jornais diários, a propaganda evidencia a flexibilidade das fronteiras entre a Psicologia e a Sociologia, para citar apenas alguns exemplos. (MACHADO, 2011, p. 172)

A problemática apontada pelo autor, sinaliza para a necessidade de maior articulação entre as diferentes áreas do saber, a fim de enriquecer e potencializar

\footnotetext{
${ }^{19}$ Segundo Machado, interdisciplinaridade é o "estabelecimento de uma intercomunicação efetiva entre as disciplinas, através da fixação de um objeto comum diante do qual os objetos particulares de cada uma delas constituem subobjetos". (MACHADO, 2011, p.184)
} 
ações voltadas à emancipação dos sujeitos envolvidos. Nesse âmbito, a interdisciplinaridade é a palavra-chave.

O filme Tempos Modernos (1936), dirigido e protagonizado pelo famoso cineasta inglês Charles Chaplin (1889 - 1977), retrata o cotidiano de operários de uma fábrica em plena Revolução Industrial. Um desses operários era Carlitos personagem vivido por Chaplin - cuja função, na linha de produção, estava restrita a apertar parafusos. Tal situação impediu Carlitos de ter uma noção do trabalho que desempenhava no contexto global, não podendo mensurar, portanto, a importância da atividade que realizava todos os dias exaustivamente. As condições de trabalho a que o personagem estava submetido contribuíram para que ele tivesse um colapso nervoso, não conseguindo mais parar de fazer os movimentos que fazia muito rapidamente dentro da fábrica.

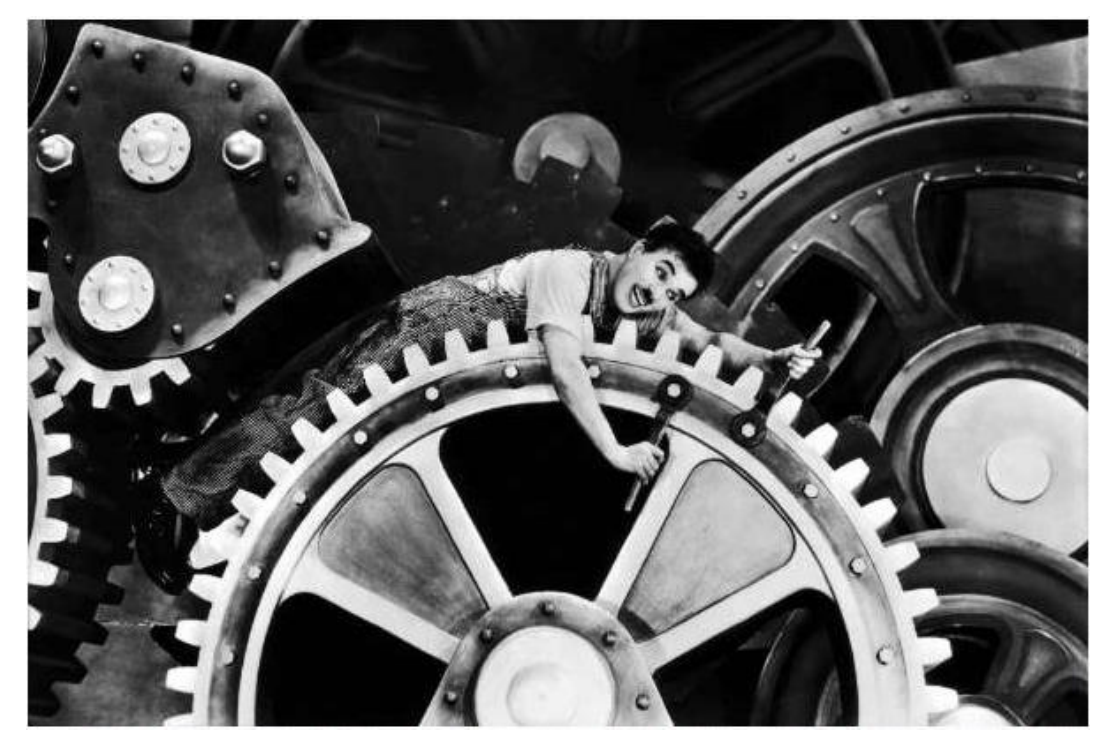

Figura 17: Cena do filme Tempos Modernos (1936).

Negligenciar a importância de uma abordagem interdisciplinar é correr o risco de "transformar" as disciplinas em linhas de montagem no interior de uma fábrica típica da época da Revolução Industrial - a escola - e os alunos em operários alienados, a exemplo de Carlitos, visto que serão incapazes de considerar o saber de modo global. A esse respeito, Morin enfatiza que "a inteligência parcelada, compartimentada, mecanicista, disjuntiva e reducionista rompe o complexo do mundo em fragmentos disjuntos, fraciona os problemas, separa o que está unido, torna unidimensional o multidimensional" (MORIN, 2000, p.43) 
O mesmo autor, aliás, alerta para o risco de o objeto estudado ter um fim em si mesmo quando trabalhado de modo desarticulado. Em suas palavras:

[...] a instituição disciplinar acarreta, simultaneamente, um risco de hiperespecialização do investigador e um risco de "coisificação" do objeto estudado, percebido como uma coisa em si, correndo-se o risco de esquecer que o objeto é extraído ou construído [...]. A fronteira disciplinar, com sua linguagem e com os conceitos que Ihe são próprios, isola a disciplina em relação às outras e em relação aos problemas que ultrapassam as disciplinas. Desse modo, o espírito hiperdisciplinar corre o risco de se consolidar, como o espírito de um proprietário que proíbe qualquer circulação estranha na sua parcela do saber. (MORIN, 2005, p. 40)

Japiassu (1976) entende que a interdisciplinaridade se apresenta como três protestos:

\begin{abstract}
a) contra um saber fragmentado, em migalhas, pulverizado numa multiplicidade crescente de especialidades, em que cada uma se fecha como que para fugir ao verdadeiro conhecimento; b) contra o divórcio crescente, ou esquizofrenia intelectual, entre uma universidade cada vez mais compartimentada, dividida, subdividida, setorizada e subsetorizada, e a sociedade em sua realidade dinâmica e concreta onde a "verdadeira vida" sempre é percebida como um todo complexo e indissociável. Ao mesmo tempo, porém contra, essa própria sociedade, na medida em que ela faz tudo o que pode para limitar e condicionar os indivíduos a funções estreitas e repetitivas, para aliená-los de si mesmos, impedindo-os de desenvolverem e fazerem desabrochar todas as suas potencialidades e aspirações mais vitais; c) contra o conformismo das situações adquiridas e das "ideias recebidas" ou impostas. (JAPIASSU, 1976, p. 43)
\end{abstract}

Do ponto de vista desse autor, a importância da interdisciplinaridade está na superação de todo e qualquer enfoque fragmentado do saber, pois só assim estar-seá contribuindo para uma formação ampla dos alunos, ou seja, uma formação que viabilize sua inserção no mundo, criticando e compreendendo as inúmeras informações que os atingem cotidianamente.

Observamos assim um consenso: o caráter estritamente disciplinar dificulta a aprendizagem dos alunos, uma vez que é ausente o estímulo ao estabelecimento de conexões entre os fatos e conceitos e, sendo assim, abordagens interdisciplinares se fazem necessárias. Para Machado, "[...] a ideia da Interdisciplinaridade tende a transformar-se em bandeira aglutinadora na busca de uma visão sintética, de uma reconstrução da unidade perdida, da interação e da complementaridade nas ações envolvendo diferentes disciplinas" (MACHADO, 2011, p. 172). Ele acredita, ainda, que o "necessário trabalho interdisciplinar" só é viável caso seja rompida a organização 
linear à qual estão submetidas as disciplinas escolares e que é, sob seu ponto de vista, mais patente na Matemática. Esse modo de organização parte do pressuposto de que é necessário estabelecer pré-requisitos e de que há percursos necessários a serem obedecidos. Em suas palavras:

A característica mais marcante de tal organização é a fixação de uma cadeia linear de marcos temáticos que devem ser percorridos sequencialmente, expressando passos necessários no caminho do que é considerado mais simples ao mais complexo. Se a cadeia for, digamos $A \rightarrow B \rightarrow F \rightarrow G \rightarrow X$ $\rightarrow S \rightarrow D \rightarrow \ldots$, então a não abordagem do tema $G$ impossibilitaria o tratamento do tema $X$, retendo-se o aluno no ponto $G$ até que o mesmo seja aprendido. Apesar de multiplicarem-se os exemplos de casos em que, por exemplo, o conhecimento de $S$ favoreceu o conhecimento de $X$, ou de que o conhecimento de $X$ é possível sem o perfeito conhecimento de $G$, a linearidade, como um dogma, nunca parece ser posta em questão. (MACHADO, 2011, p. 180)

Diante disso, ele também sinaliza para a urgência de que o conhecimento seja concebido como uma rede de relações e significados, amenizando, assim a linearidade no tratamento dos conteúdos disciplinares. Em suas palavras:

\begin{abstract}
Esta nos parece ser a chave para a emergência, na escola ou na pesquisa, de um trabalho verdadeiramente interdisciplinar: a ideia de que conhecer é cada vez mais conhecer o significado, de que o significado de A constrói-se através das múltiplas relações que podem ser estabelecidas entre $A$ e $B, C$, $D, E, X, T, G, K, W$ etc., estejam ou não as fontes de relações no âmbito da disciplina que se estuda. Insistimos: não se pode pretender conhecer A para então, poder-se conhecer B ou C, ou X, ou Z, mas o conhecimento de A, a construção do significado de $A$ faz-se a partir das relações que podem ser estabelecidas entre A e B, C, X, G, ... e o resto do mundo. (MACHADO, 2011, pp. 181, 182)
\end{abstract}

Ao conceber o conhecimento como uma rede de significações, parte-se da hipótese de que não existe nenhum caminho logicamente necessário. Pode-se, por exemplo, "tecer" a rede a partir de qualquer ponto e os significados, por sua vez, são construídos por meio conexões entre os diversos temas. Aprender segundo essa imagem é "navegar" num "mar" de relações.

Machado ressalta, porém, que tal concepção não implica eliminação ou diminuição da importância das disciplinas e nem tampouco extingue a organização linear em que as mesmas estão pautadas:

$\mathrm{Na}$ construção do conhecimento, sempre serão necessários disciplina, ordenação, procedimentos algorítmicos, ainda que o conhecimento não 
possa ser caracterizado apenas por estes elementos constitutivos, isoladamente ou em conjunto. Afirmar-se que os procedimentos algorítmicos não esgotam os processos cognitivos não significa que tais procedimentos possam ser dispensados; seguramente não o podem. (MACHADO, 2011, p. 183)

Partidário da noção do conhecimento como rede, Spinelli (2011) afirma que a busca por relações interdisciplinares

[...] exige pensar na possibilidade de tecer uma rede de significados conceituais com base em temas identificados em planos acima dos tradicionais âmbitos disciplinares e que, dada a sua universalidade, forneçam a energia para a ligação entre conceitos de diversas disciplinas. (SPINELLI, 2011, p. 91)

O autor pondera que situações que aglutinam os esforços de várias disciplinas em função de agregar significados a conteúdos de apenas uma delas são insuficientes para que sejam postas em prática abordagens interdisciplinares. Para ele, a busca pela interdisciplinaridade se inicia a partir de temas que não pertencem a nenhuma disciplina, mas que provocam a reunião de várias delas com o objetivo único de construir uma rede de significados conceituais. Diante isso, o contexto é o ponto de partida para que propostas interdisciplinares sejam encaminhadas.

Além de contextos que promovam a interdisciplinaridade, existem outros que embora não contribuam para a extrapolação das fronteiras disciplinares, também possibilitam que uma rede de significados seja construída a partir deles. Tais contextos remetem-se basicamente às aplicações cotidianas, à História da Matemática e à intradisciplinaridade 20 .

Contextos que remetem às aplicações práticas são aqueles que possibilitam resolver situações do cotidiano. Para Spinelli (2011) a constituição de tais contextos deve ser encarada como estopim para a construção de uma rede de significados, e não apenas para encontrar resposta à pergunta: "Para que serve isto que estou aprendendo/ensinando?". Segundo o autor:

Trata-se, portanto, de utilizar o conhecimento matemático como ferramenta, para além de explicar o porquê distou ou aquilo, interpretar todo o evento,

${ }^{20}$ Relação de significados conceituais internos à própria disciplina. 
reconfigurando-o quando necessário a fim de que permita o estabelecimento da maior gama de relações conceituais. (SPINELLI, 2011, p. 77)

O autor alerta ainda para o fato de que nem sempre é possível criar um elo evidente entre conceito e aplicação cotidiana e que isso pode gerar um desconforto tanto para alunos quanto para professores. Assim, práticas pedagógicas que se baseiam na contextualização para despertar o interesse dos alunos pela Matemática e fundamentar seu ensino, podem, ao invés de contribuir para atenuar as dificuldades de aprendizagem dessa disciplina, torná-la ainda mais difícil aos alunos, podendo inclusive potencializar na escola a visão errônea de que a Matemática deve estar necessariamente a serviço da resolução de problemas práticos.

Já os contextos que remetem à História da Matemática são aqueles que permitem "ressignificar elementos da época do surgimento do conceito, especialmente os conceituais, com o objetivo de produzir sequências de atividades que aproximem as condições históricas da realidade atual do estudante" (SPINELLI, 2011, p. 97). De acordo com o mesmo autor:

\footnotetext{
Aceitar que a construção conceitual pode ser estimulada a partir do recurso à História a Matemática implica em entender que a evolução do conhecimento matemático, construído e acumulado durante tantos anos, quando reproduzida na escola, é capaz de incitar a produção de novos significados conceituais. (SPINELLI, 2011, p. 99)
}

Desta forma, um contexto histórico para ser considerado significativo não pode se limitar a apenas situar historicamente as iniciativas de estudiosos na produção do conhecimento de determinado conceito ou a simples apresentação de dados biográficos sobre este ou aquele matemático famoso que viveu em séculos ou até milênios anteriores.

Por fim, contextos que remetem à intradisciplinaridade se referem,

[...]ao conjunto de circunstâncias que selecionamos e que permitem organizar percursos sobre a rede conceitual, relacionando significados conceituais internos à própria disciplina. O principal, mas não único critério para a seleção dos componentes do conjunto de circunstâncias nesse caso, é a conectividade lógica entre os significados conceituais [...] (SPINELLI, 2011, p. 106) 
O cálculo de áreas de polígonos e a aplicação do teorema de Pitágoras ou ainda, as relações entre a álgebra das matrizes e as transformações isométricas de polígonos no plano, são exemplos apontados pelo próprio autor de conteúdos matemáticos que se completam do ponto de vista lógico.

A proposição de contextos intramatemáticos pressupõe conceber que o conhecimento é construído com base na rede de significados. Nesse âmbito, Spinelli considera que a organização cartesiana dos conteúdos internos da disciplina, sobretudo da Matemática, "contribui para abafar a evidência das relações entre significados conceituais existentes internamente à disciplina" (SPINELLI, 2011, p. 105)

Sobre as circunstâncias apontadas pelo autor, pode-se conceber o seguinte esquema:

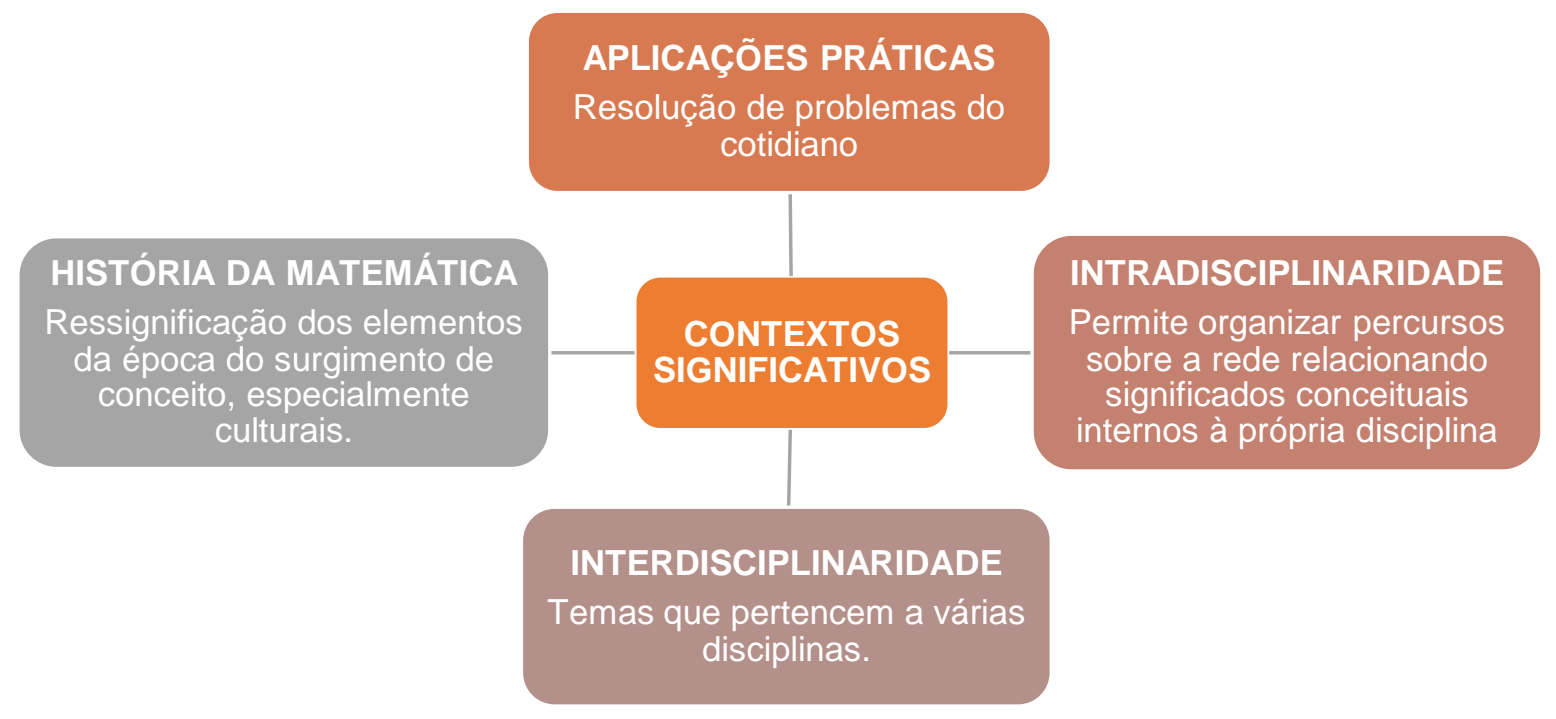

Figura 18: Circunstâncias para a composição de contextos significativos segundo Spinelli (2011).

Colocar os alunos diante de tais circunstâncias poderá contribuir para que possam atribuir significado aos conceitos matemáticos, não só porque estas podem Ihes despertar 0 interesse, mas sobretudo porque permitem que eles possam estabelecer novas relações entre significados conceituais.

É importante enfatizar que um contexto, não deve ser relacionado somente às aplicações práticas. Um conto de fadas, por exemplo, tem contexto, mas não tem aplicação prática. Nesse sentido, o contexto não elimina a ficção - fortemente 
presente num conto de fadas - permitindo, inclusive, possibilitar ir do facto ${ }^{21}$ (se refere àquilo que já está feito) para o ficto (se refere à extrapolação do fato, como por exemplos, os sonhos, ilusões e fantasias). Segundo Machado (2013):

O vivido alimenta-se do imaginado, do que fazemos de conta, dos fictos. Sonhos, ilusões, fantasias, utopias, ficções são alimentos para nossos projetos. Ter ilusões é querer continuar jogando o jogo da vida. Iludere vem de ludus, jogo. Não vivemos de ilusões, mas não sobrevivemos sem elas. Sem ilusão não se faz projeto. Os fictos que idealizamos prefiguram os factos que vivenciamos. (MACHADO, 2013)

Dessa forma, colocar os alunos diante de situações que os levem a sonhar ou a imaginar é fundamental, pois é a partir dos sonhos que novos projetos poderão ser estabelecidos. Assim, podemos arriscar dizer que um ficto pode levar a um projeto, que por usa vez, gera um facto que promove um novo ficto, em outras palavras, um projeto nasce de sonhos e leva à construção de novos sonhos.

${ }^{21}$ Particípio passado do verbo latino facere (fazer). 


\section{Capítulo 4}

\section{A pesquisa propriamente dita: os Objetos Educacionais Digitais presentes nos livros didáticos (PNLD 2014)}

Várias têm sido as políticas e iniciativas governamentais no Brasil na busca da inserção da informática na escola. Segundo Borba e Penteado (2012), uma das primeiras ações nesse sentido ocorreu em 1981, com a realização do I Seminário Nacional de Informática na Educação, na Universidade de Brasília (UnB). A importância de realizar pesquisas sobre o uso do computador como ferramenta auxiliar no processo de ensino e aprendizagem e recomendações que apontavam para a necessidade de sempre priorizar, no planejamento de ações, os aspectos pedagógicos, muitas vezes em detrimento dos tecnológicos, foram pontos incluídos na pauta desse evento.

Em 1982, ocorreu na Universidade Federal da Bahia (UFBA), o II Seminário Nacional de Informática na Educação, cujo objetivo era reunir subsídios para a criação de projetos-piloto, a partir das reflexões de especialistas das áreas de educação, psicologia, informática e sociologia. Nesse evento, foi dada ênfase ao fato de o computador não poder ser encarado como uma ferramenta que substitui o professor, deixando explícito que deveria estar sujeito aos objetivos da educação e não na determinação desses objetivos. Foi a partir desse seminário que surgiram projetos como: Educom, Formar e Proninfe.

O Projeto Educom foi lançado pela Secretaria Especial de Informática (SEI) em 1983. O objetivo desse projeto era criar centros pilotos em universidades brasileiras para desenvolver pesquisas sobre as diversas aplicações do computador na educação. As universidades envolvidas com o Projeto Educom foram: Universidade Federal do Rio de Janeiro (UFRJ), Universidade Federal do Rio Grande do Sul (UFRGS), Universidade de Campinas (UNICAMP), Universidade Federal de Minas Gerais (UFMG) e Universidade Federal de Pernambuco (UFPE).

O Projeto Formar foi concebido pelo Comitê Assessor de Informática e Educação (CAIE) do Ministério da Educação e Cultura (MEC) e seu objetivo era formar recursos humanos para o trabalho na área de informática educativa. Assim, foram 
oferecidos cursos de especialização em Informática na Educação, em nível de pósgraduação lato sensu, ministrados na Unicamp por pesquisadores e especialistas dos centros pilotos do Projeto Educom, em 1987 (Formar I) e 1989 (Formar II), cujo público alvo eram professores de diferentes Estados. Segundo Moraes ${ }^{22}$.

Com a escolha do nome Projeto FORMAR, tínhamos em mente marcar uma transição importante em nossa cultura de formação de professores. Ou seja, pretendíamos fazer uma distinção entre os termos formação e treinamento, mostrando que não estávamos preocupados com adestramento, ou em simplesmente adicionar mais uma técnica ao conhecimento que o profissional já tivesse, mas, sobretudo, pretendíamos que o professor refletisse sobre a sua forma de atuar em sala de aula e propiciar-lhe condições de mudanças em sua prática pedagógica, na forma de compreender e conceber o processo ensino-aprendizagem, levando-o a assumir uma nova postura como educador. (MORAES, 1997, p. 22, grifo da autora)

No final do curso, os profissionais deveriam atuar como multiplicadores em sua região de origem e dessa iniciativa surgiram os Centros de Informática na Educação (CIEd) em instituições de ensino da Educação Básica. Sobre o alcance de cada CIEd, Moraes comenta:

De um centro inicialmente voltado para o atendimento aos alunos, à comunidade em geral e à formação de professores, o CIEd passou, na maioria dos estados, a ser também um núcleo central de coordenação pedagógica das atividades desenvolvidas, a partir da criação de subcentros e laboratórios. (MORAES, 1997, p. 23)

O Programa Nacional de Informática Educativa (Proninfe) foi lançado em 1989 pelo MEC e tinha como objetivo fomentar infraestrutura de suporte nas escolas e realizar a capacitação contínua e permanente de professores, técnicos e pesquisadores.

Em 1997, é criado pelo MEC o Programa Nacional de Tecnologia Educacional (Prolnfo) cujo objetivo é "promover o uso pedagógico de Tecnologias de Informática e Comunicações (TIC) na rede pública de ensino fundamental e médio" (FNDE, 2015). Trata-se de um programa de governo, ainda em vigor, que, até o ano de 2012, havia equipado mais de 2000 escolas e investido na formação de mais de 20 mil professores

\footnotetext{
22 Maria Candida Moraes foi coordenadora das atividades de informática na educação desenvolvidas pelo MEC entre os anos de 1981 e 1992.
} 
através de 244 Núcleos de Tecnologia Educacional (NTE), instalados em diversas partes do país.

O quadro a seguir permite uma visão global de algumas ações governamentais relacionadas à questão da Informática na escola:

\section{PRIMEIRAS INICIATIVAS GOVERNAMENTAIS DE IMPLEMENTAÇÃO DA INFORMÁTICA NA}

\section{ESCOLA}

\begin{tabular}{|c|c|c|}
\hline ANO & PROGRAMAS & CONTRIBUIÇÕES \\
\hline 1981 & $\begin{array}{l}\text { I Seminário Nacional } \\
\text { de Informática na } \\
\text { Educação }\end{array}$ & \multirow{2}{*}{$\begin{array}{l}\text { - Reconhecimento da importância do computador no processo de } \\
\text { ensino e aprendizagem. } \\
\text { - Reconhecimento de que o computador não tem um fim em si } \\
\text { mesmo. } \\
\text { - Surgimento dos projetos como Educom, Formar e Proinfe. }\end{array}$} \\
\hline 1982 & $\begin{array}{l}\text { II Seminário Nacional } \\
\text { de Informática na } \\
\text { Educação }\end{array}$ & \\
\hline 1983 & Educom & $\begin{array}{l}\text { - Desenvolvimento de pesquisas sobre as diversas aplicações do } \\
\text { computador na educação. }\end{array}$ \\
\hline 1987 & Formar I & \multirow{2}{*}{$\begin{array}{l}\text { - Formação de recursos humanos para o trabalho na área de } \\
\text { informática educativa. } \\
\text { - Contribuíram para o surgimento dos CIEd. }\end{array}$} \\
\hline 1989 & Formar II & \\
\hline 1989 & Proninfe & $\begin{array}{l}\text { - Deu continuidade às iniciativas anteriores. } \\
\text { - Criou laboratórios e centros para a capacitação contínua e } \\
\text { permanente de professores. }\end{array}$ \\
\hline 1997 & Prolnfo & $\begin{array}{l}\text { - Promoveu o uso pedagógico das TIC no ensino público } \\
\text { fundamental e médio. } \\
\text { - Equipou mais } 2000 \text { escolas, até } 2012 \text {. } \\
\text { - Investiu na formação de mais de } 20.000 \text { professores, até } 2012 \text {. }\end{array}$ \\
\hline
\end{tabular}

Quadro 5: Algumas políticas de implementação da informática nas escolas ${ }^{23}$.

Todas as iniciativas do governo federal contribuíram para que os laços entre Informática e Educação fossem estreitados, não apenas porque as escolas passaram a ser equipadas com computadores, mas também pelo fato de que grupos de pesquisa começaram a surgir em torno da discussão de como os recursos e os benefícios da

\footnotetext{
${ }^{23}$ Ainda vigoram, o Projeto Banda Larga nas Escolas (PBLE), lançado em 2008, com o objetivo de conectar todas as escolas públicas urbanas à internet e o Programa Um computador por Aluno (PROUCA), criado em 2010, com o intuito de promover a inclusão digital por meio da distribuição de um computador portátil (laptop) para cada estudante e professor de Educação Básica em escolas públicas.
} 
informática poderiam vir a ser utilizados de forma consciente, eficaz e crítica. Gitirana, Bittar e Ignácio afirmam que também é necessário haver

[...] o desenvolvimento de tecnologias apropriadas para a educação, planejadas a partir de conceitos, não somente das áreas de cada saber e da ciência da computação, como também de preceitos educacionais e da área de ensino, como, em particular, da Educação Matemática. (GITIRANA; BITTAR; IGNÁCIO, 2014, p. 1)

Nesse âmbito, os autores apontam os Objetos Educacionais Digitais (OED) como exemplos dessas tecnologias. Os OED são recursos recentemente integrados a algumas coleções de livros didáticos adquiridas pelo MEC para as escolas públicas dos estados e municípios que aderiram ao Programa Nacional do Livro Didático (PNLD).

Existem diferentes definições, propostas por vários autores, para Objetos de Aprendizagem (OA) e a que será adotada é a do Grupo de Pesquisa sobre Tecnologias na Educação Matemática (GPTEM) da Universidade Federal do Paraná (UFPR). Segundo o grupo um OA é "qualquer recurso virtual, de suporte multimídia, que pode ser usado e reutilizado com o intuito de apoiar e favorecer a aprendizagem, por meio de atividade interativa, na forma de animação ou simulação" (GPTEM) ${ }^{24}$. Balbino (2014) adota essa mesma definição para os OED, entendo-os como um recurso que tem por objetivo mediar e qualificar o processo de ensino e aprendizagem.

A possibilidade de as coleções de livros didáticos incorporarem de maneira suplementar ${ }^{25}$ tais objetos foi o aspecto inovador do edital do PNLD 2014. Esses recursos, segundo o mesmo edital, devem ser apresentados nas categorias audiovisual $^{26}$, jogo eletrônico educativo ${ }^{27}$, simulador $^{28}$ e infográfico animado ${ }^{29}$, ou reunir todas ou algumas dessas.

\footnotetext{
24 Disponível em: < http://gptem5.wix.com/gptem\#!sobre-1/cfen >. Acesso em 01 abr. 2016.

25 O termo suplementar foi aqui utilizado dado que, segundo o edital, a abordagem feita nas coleções de livros didáticos impressos não poderia depender do referido recurso. Dessa forma, seria possível aprovar uma coleção de livros impressos ainda que todos os seus objetos educacionais digitais não fossem aprovados.

${ }^{26}$ Filmes ou animações.

${ }^{27}$ Recurso interativo cujo objetivo é completar uma tarefa, vencer um desafio, obter a maior pontuação etc.

${ }^{28}$ Simulação de um processo ou mecanismo obtendo resultados realistas.

${ }^{29}$ Recurso interativo que se utiliza de elementos visuais (tipográficos, gráficos, mapas, ilustrações ou fotos) para explicar algum assunto.
} 
$\mathrm{Na}$ área de Matemática, dentre as 10 (dez) coleções de livros aprovadas pelo PNLD 2014, 3 (três) contêm OED. Nessas três coleções são encontrados 16 OED:

\begin{tabular}{|c|c|c|}
\hline Coleções & OED presentes & Descrição \\
\hline \multirow{8}{*}{$\begin{array}{l}\text { Vontade de } \\
\text { saber } \\
\text { matemática } \\
\text { (FTD) }\end{array}$} & $\begin{array}{c}\text { Negócios do oriente } \\
\text { (6ำ ano })\end{array}$ & $\begin{array}{l}\text { Simulador de soroban e testes envolvendo adições e } \\
\text { subtrações utilizando o instrumento. }\end{array}$ \\
\hline & $\begin{array}{l}\text { Número do Brasil } \\
\qquad\left(6^{\circ} \text { ano }\right)\end{array}$ & Infográfico com dados sobre regiões e estados brasileiros. \\
\hline & $\begin{array}{l}\text { Analisando medidas } \\
\text { (8으o })\end{array}$ & $\begin{array}{l}\text { Simulador de cálculo da moda, mediana, média, máximo e } \\
\text { mínimo da idade, peso e altura de até } 5 \text { personagens. }\end{array}$ \\
\hline & $\begin{array}{r}\text { Sorteando bolas } \\
\left(8^{\circ} \text { ano }\right)\end{array}$ & $\begin{array}{l}\text { Simulador de sorteio que apresenta os resultados em gráfico } \\
\text { e tabela. }\end{array}$ \\
\hline & $\begin{array}{l}\text { Quadriláteros } \\
\qquad\left(8^{\circ} \text { ano }\right)\end{array}$ & Jogo que explora propriedades de quadriláteros. \\
\hline & $\begin{array}{l}\text { Juros simples e } \\
\text { composto } \\
\qquad\left(9^{\circ} \text { ano }\right)\end{array}$ & Simulador de gráficos sobre aplicação financeira. \\
\hline & $\begin{array}{l}\text { Jogo dos arcos de } \\
\text { circunferência } \\
\qquad\left(9^{\circ} \text { ano }\right)\end{array}$ & $\begin{array}{l}\text { Explora o conceito de ângulo, arco, medida do ângulo e } \\
\text { comprimento de arco. }\end{array}$ \\
\hline & $\begin{array}{c}\text { Jogo dos aquários } \\
\text { (9ำ ano) }\end{array}$ & $\begin{array}{l}\text { Explora o volume de água em recipientes com a forma de } \\
\text { paralelepípedos. }\end{array}$ \\
\hline \multirow{5}{*}{$\begin{array}{c}\text { Projeto } \\
\text { Araribá } \\
\text { Matemática } \\
\text { (Moderna) }\end{array}$} & $\begin{array}{r}\text { O corpo humano } \\
(60 \text { ano })\end{array}$ & Infográfico que explora grandezas e medidas. \\
\hline & Área $\quad$ (6ㅇao $)$ & Audiovisual que explora a comparação de áreas no geoplano. \\
\hline & $\begin{array}{l}\text { Equipamentos de } \\
\text { mergulho } \\
\qquad\left(7^{\circ} \text { ano }\right)\end{array}$ & $\begin{array}{l}\text { Audiovisual que apresenta características das roupas de } \\
\text { mergulho e sua evolução, relacionando os números } \\
\text { negativos à profundidade a que os mergulhadores chegam. }\end{array}$ \\
\hline & $\begin{array}{l}\text { Cálculo algébrico } \\
\qquad\left(8^{\circ} \text { ano) }\right.\end{array}$ & $\begin{array}{l}\text { Audiovisual que apresenta o Teorema de } \text { Pick }^{30} \text { para } 0 \\
\text { cálculo de área de polígono. }\end{array}$ \\
\hline & $\begin{array}{l}\text { Localizando terremotos } \\
\qquad\left(8^{\circ} \text { ano }\right)\end{array}$ & $\begin{array}{l}\text { Audiovisual que discute posições relativas de circunferências } \\
\text { como um meio para encontrar o epicentro de um terremoto. }\end{array}$ \\
\hline \multirow{3}{*}{$\begin{array}{c}\text { Matemática } \\
\text { - teoria e } \\
\text { contexto } \\
\text { (Saraiva) }\end{array}$} & $\begin{array}{l}\text { Em busca do mel } \\
\text { (6- ano) }\end{array}$ & Jogo sobre frações. \\
\hline & $\begin{array}{l}\text { Nove para casa } \\
\left.\text { ( } 7^{\circ} \text { ano }\right)\end{array}$ & $\begin{array}{l}\text { Jogo que aborda a representação infinita e periódica de } \\
\text { algumas frações. }\end{array}$ \\
\hline & $\begin{array}{l}\text { Um pouco da história da } \\
\text { geometria } \\
\qquad\left(7^{\circ} \text { ano }\right)\end{array}$ & Audiovisual que contém dados sobre a história da geometria. \\
\hline
\end{tabular}

Quadro 6: Os OED das obras aprovadas no PNLD 2014.

30 O Teorema de Pick afirma que: Se um polígono no plano cartesiano tem apenas vértices de coordenadas inteiras então sua área é dada pela fórmula $A=\frac{1}{2} f+i-1$, onde $f$ e $i$, correspondem ao número de pontos com coordenadas inteiras no contorno e no interior do polígono, respectivamente. 
Antes de estabelecer os critérios para o exame dos referidos OED, convém tecer alguns comentários a respeito da importância da interface dos mesmos.

\subsection{Interface}

Inúmeros são os trabalhos que se propõem a estabelecer parâmetros para analisar os software voltados para o ensino e é comum a todas essas produções a preocupação com a interface, que Royo ${ }^{31}$ define como sendo "[...] a área de comunicação entre o homem e a máquina" (ROYO, 2008, p. 89 apud PREVEDELLO, 2011, p.48). Assim, a interface pode influenciar na maneira como o aluno se apropria do conteúdo e, também, pode interferir em sua aprendizagem.

Segundo Passos (2010), quanto melhor a interface, mais eficiente é a interação homem - máquina e mais conhecimento é produzido. A busca por formas cada vez mais eficazes de comunicação e o consequente desenvolvimento de tecnologias se justificam, de acordo com o autor, pela necessidade de o homem interagir com o meio que o cerca e também com seus pares e, isso, reflete no aperfeiçoamento das interfaces. Em suas palavras:

[...] a necessidade de interação impulsiona o homem a buscar recursos linguísticos e formas de expressão e, nesse ímpeto, desenvolver tecnologia e refinar o traço para o desenho, o que resulta em interfaces cada vez mais aprimoradas. Ao mesmo tempo, melhores interfaces promovem interações mais eficientes e aumentam a produção de conhecimento [...] (PASSOS, 2010, p.32)

Diante disso, Reategui, Boff e Finco (2010) levantam a bandeira da importância de examinar as interfaces de objetos de aprendizagem:

A avaliação da interface do objeto de aprendizagem tem um papel de grande importância na identificação de sua qualidade como instrumento pedagógico. Uma interface bem construída pode ter influência positiva tanto na usabilidade do software (facilidade de uso) quanto em sua eficiência como facilitador dos processos de aprendizagem. (REATEGUI; BOFF; FINCO, 2010, p. 4)

${ }^{31}$ ROYO, J. Design Digital. São Paulo: Rosari, 2008. 
Dessa forma, interfaces mal elaboradas e pouco intuitivas prejudicam não somente a interação dos alunos com o OED, como também o bom trabalho pedagógico que o mesmo poderia desencadear. Em outras palavras, uma boa interface é imprescindível para que as propostas pedagógicas subjacentes aos OED possam ser colocadas em prática.

Alguns dos aspectos levados em consideração para analisar interfaces de objetos de aprendizagem são: eficiência, emprego de imagens, legibilidade de textos, orientação e navegação, feedback, consistência e design minimalista.

A eficiência "diz respeito à produtividade do usuário quando acessa a interface, a qual deve proporcionar que o usuário aprenda como utilizá-la, de maneira a conseguir realizar as suas tarefas com um alto nível de produtividade" (PREVEDELLO, 2011, p. 93). Assim, uma interface é considerada eficiente, quando ela permite ao usurário fazer o que se espera dela: permite ao estudante acessar as informações de que necessita e a realizar o trabalho de forma eficiente.

Já o emprego de imagens está relacionado ao equilíbrio no número de imagens empregadas em cada página. Reategui, Boff e Finco (2010), em consonância com as ideias de Meyer e Moreno (2007) ${ }^{32}$ acreditam que o processo de aprendizagem é mais eficiente quando poucas imagens estão associadas a um texto mais conciso. A presença excessiva de imagens, segundo os autores, dificulta o processamento das informações por parte do aluno, impondo a eles uma restrição no desempenho e na capacidade de aprendizado.

Segundo Reategui, Boff e Finco (2010) é desejável que os textos estejam legíveis, ou seja, que haja contraste suficiente entre fontes e fundo de tela e que também as fontes apresentem tamanho adequado ou permitam que sejam ampliadas ou reduzidas de acordo com a necessidade dos estudantes. De acordo com os autores, essa é uma forma de não prejudicar a construção, por parte dos alunos, de representações mentais a partir de fatos descritos no texto e seus conhecimentos preliminares.

\footnotetext{
32 MAYER, Richard; MORENO, Roxana. A Cognitive Theory of Multimedia Learning: Implications do Design Principles. Acessado em março de 2007. Disponível em:

$<$ http://citeseerx.ist.psu.edu/viewdoc/download?doi=10.1.1.105.5077\&rep=rep1\&type=pdf $>$ Acesso em 01 abr.2016.
} 
A orientação e navegação está relacionada aos elementos da interface que permitem ao aluno se localizar no objeto. Para justificar a importância desse aspecto, Reategui, Boff e Finco recorrem às ideias de Thissen (2004) ${ }^{33}$, ao afirmarem que,

[...] no ser humano, a sensação de estar perdido pode gerar um sentimento de insegurança e mesmo de pânico. Tal sentimento é observável no mundo real, quando nos perdemos em uma cidade ou em uma floresta, e também no mundo computacional, quando não sabemos exatamente que função está sendo executada pelo computador, o que ainda temos a fazer e como. (REATEGUI; BOFF; FINCO, 2010, p. 5)

Dessa forma, eles consideram que os elementos presentes na interface, como títulos, rótulos, links ou ícones, devem permitir ao aluno saber em que ponto se encontra no objeto.

O feedback está associado "ao retorno que a interface deve oferecer ao usuário após a realização de uma tarefa, do ponto de vista de dar uma resposta para a realização da mesma, tanto positiva quanto negativa" (PREVEDELLO, 2011, p. 94). Nesse âmbito, o feedback é a informação apresentada ao aluno com a intenção de modificar o seu modo de pensar e de redirecionar suas ações até alcançar o objetivo pretendido. Dessa forma o feedback pode não só pode levar os alunos à reflexão como também pode auxiliá-los no processo de depuração. Amparada nas ideias de Horton (2000) ${ }^{34}$, Cardoso (2011) afirma que:

\begin{abstract}
Para respostas certas, [...] o feedback deve indicar que o aluno estava certo e explicar por quê. Pode-se também desafiar o aluno e levá-lo a pensar em como ele chegou à resposta certa. O feedback para resposta certa pode ainda fornecer informações adicionais sobre o conteúdo. Para respostas erradas, deve-se usar um termo neutro como "incorreto", sem o uso de exclamações. A mensagem deve ser gentil, para não constranger e desmotivar o aluno, e deve apontar claramente o problema. Além disso, o feedback deve encorajar o aluno a tentar novamente e sugerir dicas para que o aluno chegue à resposta certa. (CARDOSO, 2011, p. 27)
\end{abstract}

Acontece que nem sempre o feedback fornecido pelos software voltados para o ensino atende ao que preconiza a autora e, nesses casos, cabe ao professor suprir tal deficiência.

33 THISSEN, F. Screen Design Manural: Communicating Effectively Through Multimedia. Berlin: Springer Verlag, 2004.

${ }^{34}$ HORTON, William K. Test and exercise lernaning. Designing Web-based training. John Wiley e Sons Publisher, 2000. 
A consistência é a característica da interface que possibilita ao aluno realizar tarefas similares por meio de operações e elementos semelhantes. Prevedello (2011) concorda com Preece, Rogers e Sharp $(2005)^{35}$ ao reconhecer que interfaces que apresentam consistência são mais fáceis de aprender, isto é, de utilizar.

Por fim, uma interface com design minimalista é aquela que evita fazer uso de informações irrelevantes ou raramente necessárias. Nesse sentido, Prevedello (2011), em consonância com Nielsen $(2000)^{36}$, considera que é desejável que tal característica esteja presente nos objetos de aprendizagem.

Quando os aspectos acima apontados são bem cuidados, a interface poderá cumprir sua função de facilitar a percepção, o raciocínio e a tomada de decisões, contribuindo, assim, para um bom desempenho nas atividades.

Não é o propósito do presente trabalho examinar os OED das obras aprovadas no PNLD 2014 à luz de cada um dos aspectos acima apontados, primeiro porque, em geral, a interface de tais objetos é bem cuidada e segundo porque o interesse está em analisar - com base em critérios pedagógicos - as possíveis contribuições desses OED para uma aprendizagem significativa por parte do aluno. Todavia, por considerar que a interface é o que dá suporte para que as propostas pedagógicas sejam colocadas em prática; possíveis deficiências serão pontualmente destacadas no decorrer das análises a serem realizadas.

\subsection{Critérios para o exame dos OED}

\subsubsection{Critério 1: Relação aluno - OED - tarefa}

No capítulo 2, vimos que as concepções de Tikhomirov (1981) e Valente (1999a) convergem para o fato de que o papel do computador seria o de facilitar a construção de saberes, propiciando aos alunos a oportunidade de serem participantes ativos em sua aprendizagem. Em outras palavras, o computador deveria contribuir

\footnotetext{
${ }^{35}$ PREECE, J.; ROGERS, Y.; SHARP, H. Design de interação: além da interação homem - computador. Porto Alegre: Bookman, 2005.

${ }^{36}$ NIELSEN, J. Projetando web sites. Rio de Janeiro: Campus, 2000.
} 
para que os alunos mobilizassem suas capacidades cognitivas e construíssem eles mesmos o conhecimento.

Diante disso, é desejável que um OED contribua para que o aluno assuma uma postura ativa em que possa formular hipóteses, além de criar e validar soluções. Para que um OED atenda a essa expectativa não basta que o seu uso esteja restrito a apenas informatizar os processos de ensino que já existem.

Exemplos de software que informatizam o ensino já existente são os do tipo tutorial $^{37}$. Os tutoriais, segundo Valente (1999b), partem do princípio de que o conhecimento é construído assim como uma parede: justapondo ou sobrepondo tijolos (informações). Dessa forma, o computador, segundo o autor, "tem a finalidade de facilitar a construção dessa 'parede', fornecendo 'tijolos' do tamanho mais adequado, em pequenas doses e de acordo com a capacidade individual de cada aluno" (VALENTE, 1999b, p.2).

Para Valente (1999a), a interação aluno - computador mediada por um software do tipo tutorial "consiste na leitura da tela ou na escuta da informação fornecida, no avanço pelo material, apertando a tecla ENTER, na escolha da informação, usando o mouse e/ou resposta de perguntas que são digitadas no teclado".

O mesmo autor coloca em xeque a possível contribuição desse tipo de software para a formação de cidadãos capazes de enfrentar as mudanças da sociedade atual e é emblemático ao afirmar que: "Tanto o ensino tradicional quanto sua informatização preparam um profissional obsoleto" (VALENTE, 1999b, p. 2)

Um OED que se propõe a informatizar o ensino já existente, no máximo, pode permitir que algumas tarefas sejam realizadas de maneira mais eficiente ou ainda suprir a falta de algum material. Nesse âmbito, o professor assume papel fundamental, pois cabe a ele auxiliar os alunos a compreender o que fazem ou a processar a informação, transformando-a em conhecimento.

Na contramão dos tutoriais estão os software de programação (por exemplo, o SuperLogo 3.0), que são exemplos de software que contribuem para que os alunos

\footnotetext{
37 Segundo Valente (1999b) tutorial "é um software no qual a informação é organizada de acordo com uma sequência pedagógica particular e apresentada ao estudante, seguindo essa sequência ou então o aprendiz pode escolher a informação que desejar" (VALENTE, 1999b, p. 90)
} 
construam o seu conhecimento. Isso acontece porque ao programar, o aluno formula perguntas, levanta e testa hipóteses, estabelece analogias, cria modelos, expressa suas ideias de forma organizada e coerente e verifica a adequação das soluções encontradas. Claramente, o ciclo descrição - execução - reflexão - depuração, proposto por Valente (1999a) está subjacente. Ciclo esse que pode estar presente mesmo em atividades que não são de programação como, por exemplo, aquelas em que eles devem resolver algum problema.

Diante do exposto, quanto mais facilidades o OED oferece para a realização do ciclo descrição - execução - reflexão - depuração, mais chances ele terá de contribuir para o processo de construção do conhecimento. Assim, a expectativa é a de que o OED não apenas permita ao aluno investigar e estabelecer conjecturas, mas também, que o coloque diante de problemas desafiadores, nos quais possam percorrer as etapas do ciclo para superá-los. Assim, no que diz respeito a relação aluno - OED tarefa, pode-se definir os seguintes níveis:

\begin{tabular}{|c|c|c|c|}
\hline NÍVEL 1 & NÍVEL 2 & NÍVEL 3 & NÍVEL 4 \\
\hline $\begin{array}{c}\text { Aquilo que é proposto } \\
\text { no OED já era (ou } \\
\text { pode ser) feito sem o } \\
\text { uso do computador. }\end{array}$ & $\begin{array}{c}\text { O OED melhora a } \\
\text { eficiência das tarefas ou } \\
\text { supre a eventual falta de } \\
\text { algum material. }\end{array}$ & $\begin{array}{c}\text { O OED permite ao } \\
\text { aluno investigar e } \\
\text { estabelecer } \\
\text { conjecturas. }\end{array}$ & $\begin{array}{c}\text { O OED desafia o } \\
\text { aluno contribuindo } \\
\text { perco que ele } \\
\text { perra as etapas } \\
\text { do ciclo descrição - } \\
\text { execução - reflexão } \\
\text { - depuração. }\end{array}$ \\
\hline
\end{tabular}

Quadro 7: Caracterização dos OED segundo a relação aluno - OED - tarefa.

\subsubsection{Critério 2: Mobilização de diferentes registros de representação}

No capítulo 3, vimos que as representações semióticas de um objeto matemático nos diferentes registros - língua natural, algébrico, numérico, figural - são os meios que estão à disposição para explicitar diferentes componentes conceituais de cada objeto matemático, uma vez na Matemática os objetos não são perceptíveis ou acessíveis pelos sentidos.

Para um mesmo objeto matemático existem assim várias representações e cada uma delas nos permite acessar alguma característica do objeto. Nesse sentido, 
é importante poder realizar transformações tanto no interior de um mesmo registro ou entre registros diferentes, a fim de possibilitar a apreensão conceitual deste objeto. Aliás, "não apenas não existe noesis sem semiosis, mas a semiosis é assumida como sendo uma característica necessária para garantir o primeiro passo na direção da noesis" (D'AMORE, 2005, p.60)

Essas considerações justificam o porquê de se considerar a questão dos registros como um critério para exame dos OED, uma vez que é essencial haver a mobilização e a coordenação de diferentes registros para ser possível a noesis.

$\mathrm{Na}$ análise dos OED, considerar-se-á que quanto maior for a possibilidade oferecida por um objeto para o aluno transitar de um registro a outro, mais possibilidades ele oferece para que ocorra à atribuição de significado por parte do mesmo. Tal consideração encontra respaldo na teoria dos registros de representação semiótica proposta por Raymond Duval, uma vez que, uma das premissas do autor é a de que "a compreensão (integral) de um conteúdo conceitual repousa sobre a coordenação de ao menos dois registros de representação e esta coordenação manifesta-se pela rapidez e espontaneidade da atividade cognitiva de conversão" (DUVAL, 2009, p. 51).

Resultados de experiências de Duval revelaram, por exemplo, que, em geral, os alunos têm mais facilidade para realizar a conversão do registro algébrico para o gráfico do que ao contrário e este resultado, segundo o autor, está intimamente ligado à não-congruência da conversão. Isto evidencia a importância de os alunos serem estimulados a realizar a conversão em ambos os sentidos para que possam superar tal dificuldade.

Portanto, com relação à mobilização de diferentes registros de representação, pode-se estabelecer os seguintes níveis:

\begin{tabular}{|c|c|c|c|}
\hline NÍVEL 1 & NÍVEL 2 & NÍVEL 3 & NíVEL 4 \\
\hline $\begin{array}{c}\text { O OED trabalha com } \\
\text { um único registro com } \\
\text { no máximo tratamento. }\end{array}$ & $\begin{array}{c}\text { O OED trabalha (sem } \\
\text { conversão) com dois ou } \\
\text { mais registros. }\end{array}$ & $\begin{array}{c}\text { O OED trabalha com } \\
\text { a conversão entre } \\
\text { registros em apenas } \\
\text { um sentido. }\end{array}$ & $\begin{array}{c}\text { O OED trabalha com a } \\
\text { conversão entre } \\
\text { registros em ambos os } \\
\text { sentidos. }\end{array}$ \\
\hline
\end{tabular}

Quadro 8: Caracterização dos OED quanto à mobilização de diferentes registros. 


\subsubsection{Critério 3: Interdisciplinaridade e contextualização}

No capítulo 3 foi abordada a importância do rompimento das fronteiras disciplinares como um meio de contribuir para uma formação ampla dos alunos. Desta forma, a interdisciplinaridade é vista como um dos caminhos que podem levar à desmistificação da ideia de que a Matemática tem um fim em si mesma e que esta disciplina não dialoga com as demais.

Podemos também inferir, a partir das considerações feitas no mesmo capítulo, que a contextualização cumpre não apenas o papel de motivar os alunos para o estudo de um determinado tema, como também o de permitir que eles estabeleçam relações entre diferentes objetos do conhecimento. Para tanto, é preciso colocá-los diante de circunstâncias - ideias, fatos, fenômenos etc - que se inter-relacionam e estruturam um campo fértil para que eles possam relacionar conceitos. Tais circunstâncias compõem o que Spinelli (2011) denomina por contextos significativos, que segundo ele são "aqueles que se estruturam a partir da prototeia ${ }^{38}$ de conhecimentos que os alunos possuem e que estimulam a ampliação dessa teia ${ }^{39} \mathrm{a}$ partir do estabelecimento de novas relações entre significados conceituais" (SPINELLI, 2011, p. 49).

Assim, considerar-se-á que um OED que possibilite o desencadeamento de uma abordagem interdisciplinar, ou seja, que esteja pautado em um contexto que não é próprio de uma única disciplina curricular, está em um nível superior a outro que não possibilite romper a fragmentação disciplinar.

Ainda que o contexto apresentado pelo OED não tenha potencial para dar origem a uma abordagem interdisciplinar, é possível que ela possibilite ao aluno estabelecer relações entre significados conceituais. Em virtude disso, considerar-seá que um OED que coloca o aluno diante de um contexto significativo intramatemático ou ligado às aplicações cotidianas ou à História da Matemática - está em um nível superior em comparação com outro, que por exemplo trabalha com cenários ou narrativas que apresentem os conceitos "maquiados" em situação que pouco contribuem para que os alunos estabeleçam relações entre os significados de

\footnotetext{
38 Teia (rede) inicial de conhecimentos que os alunos "levam" à escola.

$39 \mathrm{O}$ autor se refere à rede como teia.
} 
diferentes conceitos. Nesse âmbito, também serão considerados contextos significativos àqueles que permitem ao aluno sonhar ou imaginar e a partir disso sentirse estimulado a iniciar um novo projeto.

Assim, com relação à interdisciplinaridade e contextualização, pode-se conceber os seguintes níveis:

\begin{tabular}{|c|c|c|c|}
\hline NÍVEL 1 & NÍVEL 2 & NÍVEL 3 & NíVEL 4 \\
\hline $\begin{array}{c}\text { Não houve } \\
\text { preocupação com o } \\
\text { contexto. }\end{array}$ & $\begin{array}{c}\text { O contexto presente } \\
\text { no OED não é } \\
\text { significativo. }\end{array}$ & $\begin{array}{c}\text { O contexto proposto é } \\
\text { significativo, porém, } \\
\text { não propicia uma } \\
\text { abordagem } \\
\text { interdisciplinar. }\end{array}$ & $\begin{array}{c}\text { O contexto proposto } \\
\text { é significativo e tem } \\
\text { potencial para que a } \\
\text { partir dele seja } \\
\text { desencadeada uma } \\
\text { abordagem }\end{array}$ \\
& & interdisciplinar. \\
\hline
\end{tabular}

Quadro 9: Caracterização dos OED segundo à interdisciplinaridade e contextualização.

No que diz respeito a análise dos OED segundo esse critério, subjaz a crença de que o professor é capaz de explorar os contextos presentes nos OED e a partir deles promover ou não propostas interdisciplinares. Assim, a análise estará voltada para as possibilidades oferecidas pelo objeto para que o professor possa estimular os alunos a estabelecer relações entre conceitos ou para que propostas interdisciplinares sejam postas em prática. 


\section{Capítulo 5}

\section{O exame dos OED}

Neste capítulo será feita a análise - com base nos critérios estabelecidos no capítulo anterior - de 13 dos 16 OED aprovados no PNLD $2014^{40}$.

Segundo Gitirana, Bittar e Ignácio (2014), os 16 OED aprovados foram inscritos com outros 184, o que traz à tona o fato de que uma grande quantidade de objetos foram excluídos do Guia PNLD 2014. Segundo os autores, o motivo para tantas exclusões se deve principalmente à presença de erros conceituais ou induções a erros, à falta de exploração das potencialidades tecnológicas que promovam um diferencial em relação ao livro impresso, à falta de sintonia com o conteúdo explorado no livro ou à divulgação de estereótipos. Diante disso, parte-se do pressuposto de que os OED que serão aqui examinados são isentos dos problemas acima apontados.

Em primeiro lugar, convém observar que por melhor que seja um OED, o seu uso não garante uma aprendizagem significativa. A adequação de um OED depende pelo menos da forma como ele se insere nas práticas de ensino, das dificuldades dos alunos identificadas pelo professor, de uma análise das situações realizadas com alunos para os quais o objeto é destinado. Nesse sentido, é preciso que o professor primeiro defina objetivos e analise criteriosamente a escolha e, depois, a mais adequada utilização dessa ferramenta.

Fato é que nenhum OED, assim como qualquer outro software destinado à Educação Matemática, garante a emergência de todas as situações necessárias à aprendizagem de dado conceito, sendo imprescindível, portanto, que o professor preencha as eventuais lacunas. Em particular, a interação única e exclusiva com um OED não é suficiente para garantir que o aluno assuma uma postura investigativa, reconheça as diversas representações de um mesmo objeto matemático e perceba

\footnotetext{
40 Não serão analisados os OED da editora Saraiva: Em busca do mel, Nove para casa e Um pouco da história da Geometria. O motivo dessa exclusão se deve ao fato de não termos conseguido ter acesso aos referidos objetos. Foi feito contato com a Editora Saraiva, inutilmente, pois foi dada a justificativa de que esta haviam sido perdidos os direitos sobre a coleção Matemática - Teoria e Contexto (da qual os OED fazem parte).
} 
como a Matemática se articula com diferentes contextos socioculturais ou ainda, com as outras disciplinas do currículo.

Dessa forma, um OED só terá todas as suas potencialidades exploradas quando seu uso for mediado por um professor capaz de identificar as propostas pedagógicas inerentes ao mesmo e, tirar o máximo proveito delas. Além disso, é preciso, na medida do possível, garantir que o OED seja utilizado da maneira segundo a qual foi concebido, evitando, por exemplo, que os alunos burlem as regras estabelecidas a priori.

Antes de encaminhar as análises é útil retomar os critérios e os níveis estabelecidos:

\begin{tabular}{|c|c|c|c|c|}
\hline \multicolumn{5}{|c|}{ RESUMO: CRITÉRIOS E NÍVEIS } \\
\hline & NÍVEL 1 & NÍVEL 2 & NÍVEL 3 & NÍVEL 4 \\
\hline $\begin{array}{c}\text { Critério } 1 \\
\text { Relação aluno - } \\
\text { OED - tarefa }\end{array}$ & $\begin{array}{l}\text { Aquilo que é } \\
\text { proposto no } \\
\text { OED já era (ou } \\
\text { pode ser) feito } \\
\text { sem o uso do } \\
\text { computador. }\end{array}$ & $\begin{array}{l}\text { O OED melhora } \\
\text { a eficiência das } \\
\text { tarefas ou supre } \\
\text { a eventual falta } \\
\text { de algum } \\
\text { material. }\end{array}$ & $\begin{array}{l}\text { O OED permite } \\
\text { ao aluno } \\
\text { investigar e } \\
\text { estabelecer } \\
\text { conjecturas. }\end{array}$ & $\begin{array}{l}\text { O OED desafia o } \\
\text { aluno, contribuindo } \\
\text { para que ele } \\
\text { percorra as etapas } \\
\text { do ciclo descrição - } \\
\text { execução- } \\
\text { reflexão- } \\
\text { depuração. }\end{array}$ \\
\hline $\begin{array}{c}\text { Critério } 2 \\
\text { Mobilização de } \\
\text { diferentes registros } \\
\text { de representação } \\
\text { no OED }\end{array}$ & $\begin{array}{l}\text { O OED trabalha } \\
\text { com um único } \\
\text { registro com no } \\
\text { máximo } \\
\text { tratamento. }\end{array}$ & $\begin{array}{l}\text { O OED trabalha } \\
\text { (sem } \\
\text { conversão) com } \\
\text { dois ou mais } \\
\text { registros. }\end{array}$ & $\begin{array}{l}\text { O OED trabalha } \\
\text { com a } \\
\text { conversão entre } \\
\text { registros em } \\
\text { apenas um } \\
\text { sentido. }\end{array}$ & $\begin{array}{l}\text { O OED trabalha } \\
\text { com a conversão } \\
\text { entre registros em } \\
\text { ambos os sentidos }\end{array}$ \\
\hline $\begin{array}{c}\text { Critério } 3 \\
\text { Interdisciplinaridade } \\
\text { e contextualização }\end{array}$ & $\begin{array}{c}\text { Não houve } \\
\text { preocupação } \\
\text { com o contexto. }\end{array}$ & $\begin{array}{l}\text { O contexto } \\
\text { presente no } \\
\text { OED não é } \\
\text { significativo. }\end{array}$ & $\begin{array}{l}\text { O contexto } \\
\text { proposto é } \\
\text { significativo, } \\
\text { porém, não } \\
\text { propicia uma } \\
\text { abordagem } \\
\text { interdisciplinar. }\end{array}$ & $\begin{array}{c}\text { O contexto } \\
\text { proposto é } \\
\text { significativo e tem } \\
\text { potencial para que } \\
\text { a partir dele seja } \\
\text { desencadeada uma } \\
\text { abordagem } \\
\text { interdisciplinar. }\end{array}$ \\
\hline
\end{tabular}

Quadro 10: Resumo dos critérios e dos níveis. 


\subsection{Negócios do Oriente}

O OED Negócios do Oriente é destinado aos alunos do 6o ano do Ensino Fundamental e trabalha com o valor posicional no sistema decimal e também com a adição e subtração no universo dos números naturais por meio de um simulador de soroban. O soroban (figura 12) é um tipo de ábaco desenvolvido no Japão cuja estrutura é provida de hastes metálicas ao longo de cada uma das quais 5 contas podem deslizar. As contas inferiores (ichidama) têm valor "um" cada; as superiores (godama) têm valor "cinco". Diz-se que o soroban está zerado, quando não houver contas encostadas na barra central (hare).

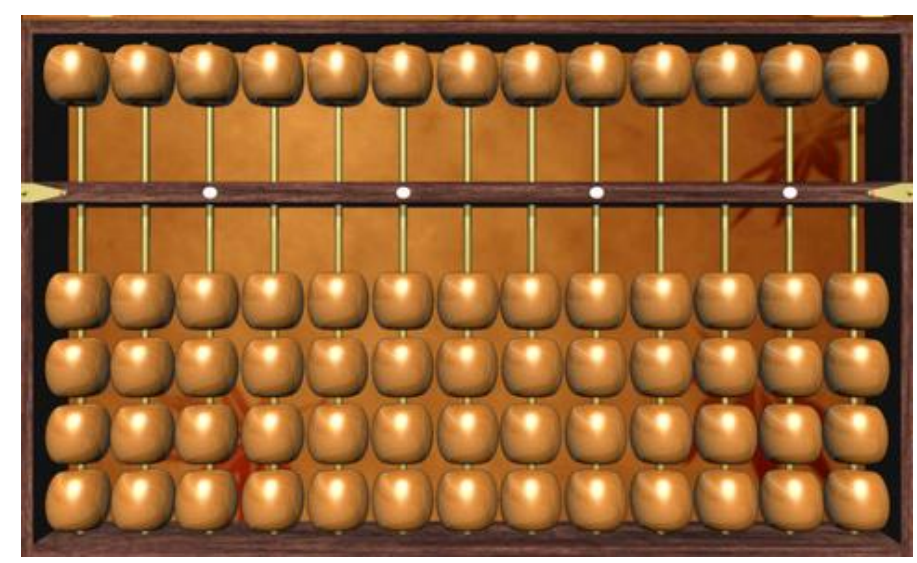

Figura 19: Soroban

Considerando a primeira haste da direita para esquerda, representamos o número 1, por exemplo, movendo uma conta inferior para junto da barra central; o número 2 , duas contas; o número 3 , três contas; o número 4 , quatro contas. O número 5 é representado movendo-se apenas a conta superior para junto da barra central. Os números de 6 a 9 são compostos pelas contas inferiores e superiores, ou seja, movem-se a conta superior e seu complemento em contas inferiores.

Uma das possibilidades oferecidas por esse OED, diz respeito a um simulador, em que o aluno tanto pode inserir um número para o objeto gerar sua representação no soroban, como pode representar um número soroban para o objeto gerar sua representação numérica. A figura, a seguir, mostra a representação do número 897.561.234: 


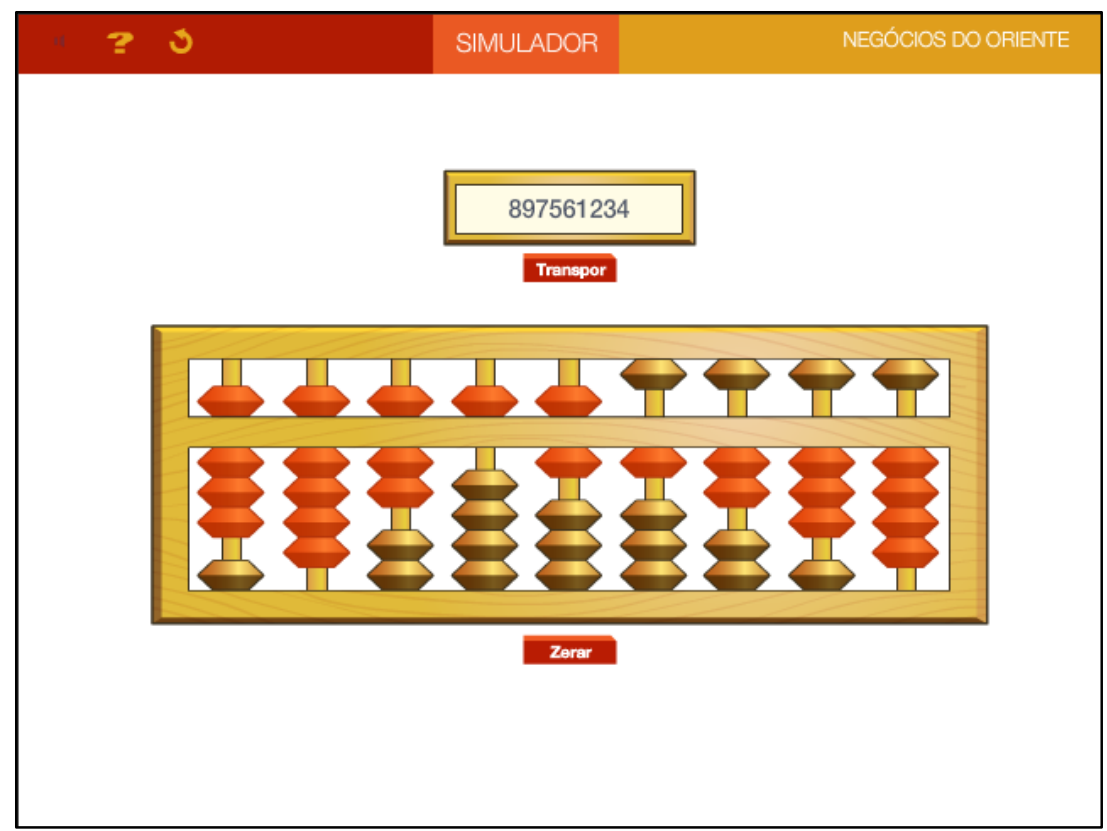

Figura 20: Número 897.561.234 representado no soroban.

Além desse simulador, é possível ao aluno, por meio da interação com o OED, efetuar adições e subtrações utilizando o soroban. Para isso ele deve optar pela opção "Testes" na tela inicial para participar de um jogo/teste, em que só avançará para o próximo nível quando realizar corretamente, por meio do soroban, os cinco cálculos propostos no nível atual. O teste é composto por 8 níveis e o grau de complexidade dos cálculos a serem efetuados vai aumentando a cada dois níveis.

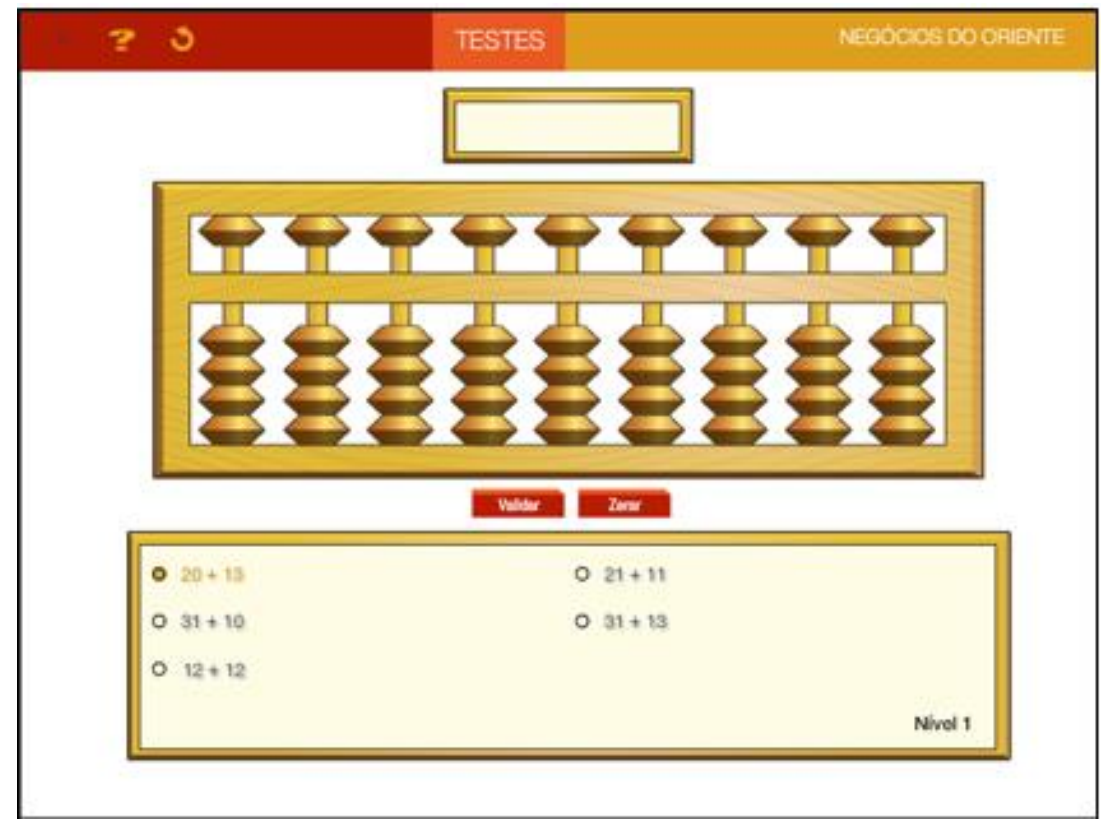

Figura 21: Cálculos solicitados no "Nível 1". 


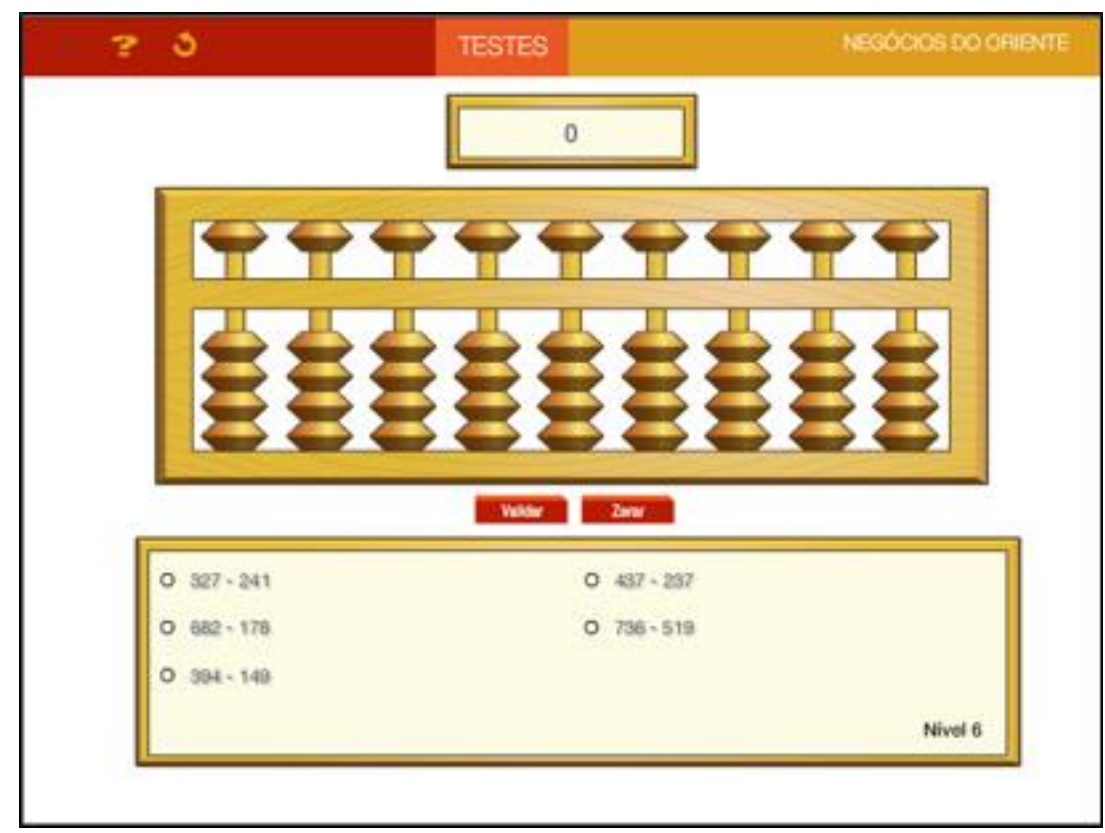

Figura 22: Cálculos solicitados no "Nível 6".

Para efetuar os cálculos, o aluno deve primeiro representar um dos números no soroban, em seguida adicionar ou subtrair as unidades, dezenas, centenas etc do outro número movimentando as contas. Segue um exemplo de como pode ser efetuada uma adição e uma subtração utilizando o soroban:

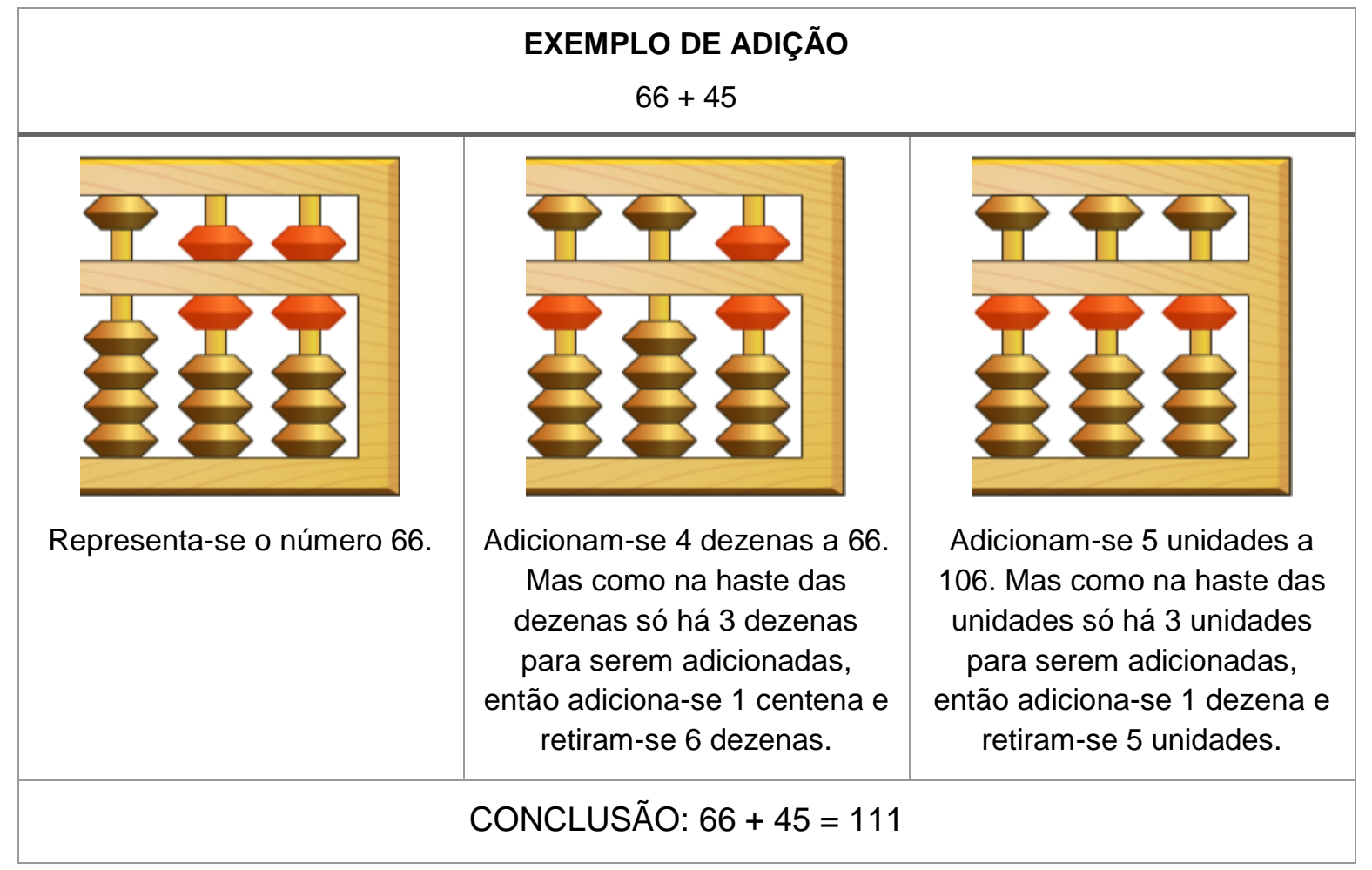

Quadro 11: Cálculo de $66+45$ no soroban. 


\section{EXEMPLO DE SUBTRAÇÃO}

$81-58$

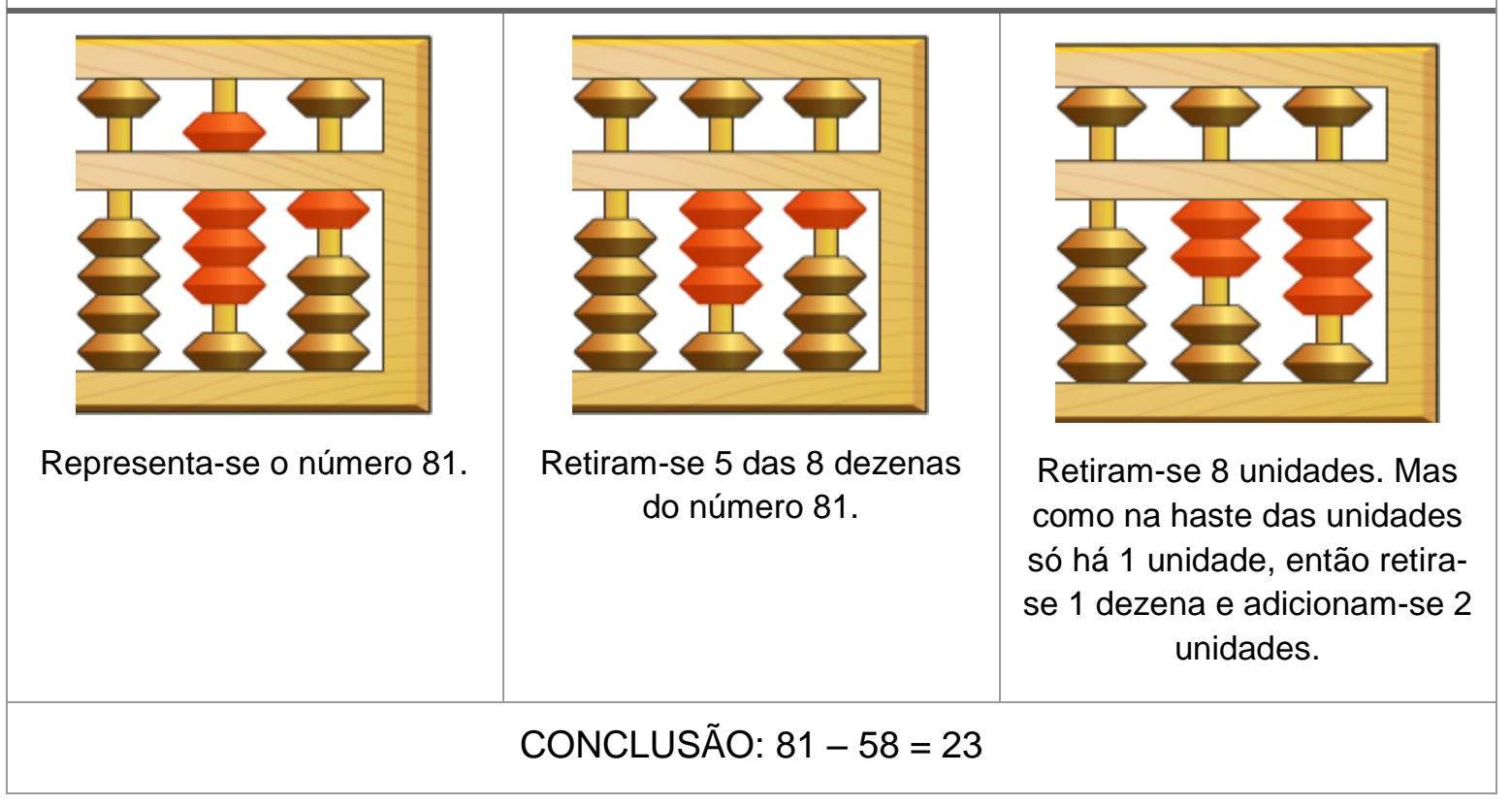

Quadro 12: Cálculo de 81 - 58 no soroban.

Vale ressaltar, que diferentemente dos algoritmos usuais de adição e subtração nos quais se sugere escrever as parcelas uma abaixo da outra e a operar da direita para a esquerda, no soroban pode-se operar em qualquer sentido. Outro aspecto importante é que com o soroban opera-se com quantidades e não com símbolos, contribuindo assim para a atribuição de significado por parte do aluno.

O soroban foi uma das primeiras calculadoras criadas pelo homem e tem desempenhado um papel importante no desenvolvimento cultural e educacional no Japão, sendo ainda, muito utilizado nas escolas sob a justificativa de contribuir para o desenvolvimento do cálculo mental e do raciocínio lógico. Além disso, o uso constante desse instrumento feito por algumas pessoas tornou possível, também, a competição saudável e esportiva entre seus usuários, exemplo disso, são os campeonatos anuais organizados no Brasil e no Japão (Grand Prix). 


\subsection{Números do Brasil}

O OED Números do Brasil é um infográfico animado destinado aos alunos do 60 ano do Ensino Fundamental e que os coloca em contato com dados coletados pelo Instituto Brasileiro de Geografia e Estatística (IBGE) a respeito das regiões (Sul, Sudeste, Centro-Oeste, Nordeste e Norte) e de estados brasileiros. Os dados são referentes à extensão territorial, população (2010), número de médicos por 1000 habitantes (2011), percentual de pessoas alfabetizadas com 5 anos ou mais de idade (2009), percentual de pessoas com acesso residencial à internet (2008), número de municípios (2010) e $\mathrm{PIB}^{43}$ per capita em reais (2010).

Conforme consta nas orientações para o professor, o OED é indicado para ser trabalhado antes do estudo específico do eixo Tratamento da Informação e tem por objetivo estimular o aluno a realizar comparações entre dados estatísticos de diferentes estados e regiões brasileiras.

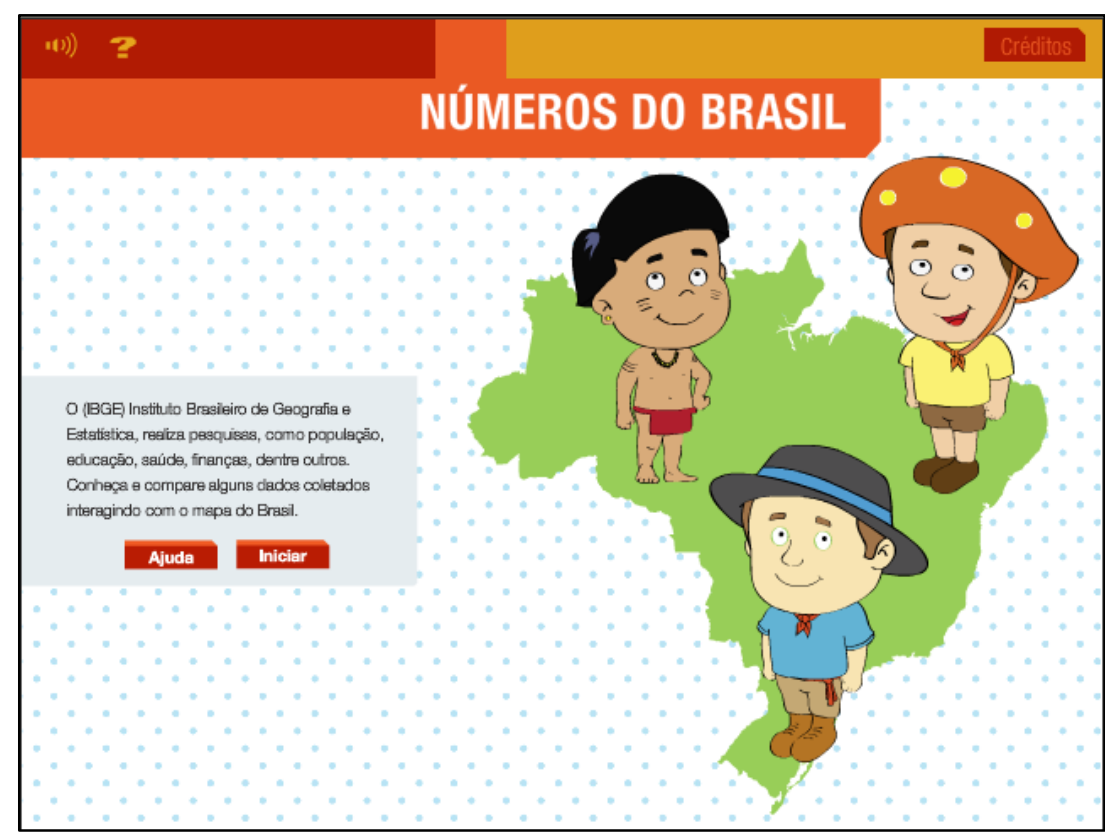

Figura 23: Tela inicial do OED Números do Brasil.

Nesse objeto é apresentado um mapa político do Brasil em que é possível o aluno clicar sobre cada uma das regiões para visualizar os dados referentes à mesma.

\footnotetext{
${ }^{43}$ Produto Interno Bruto - Corresponde à soma do valor de toda a riqueza (bens, produtos e serviços) produzida por um país em um determinado período, geralmente um ano.
} 


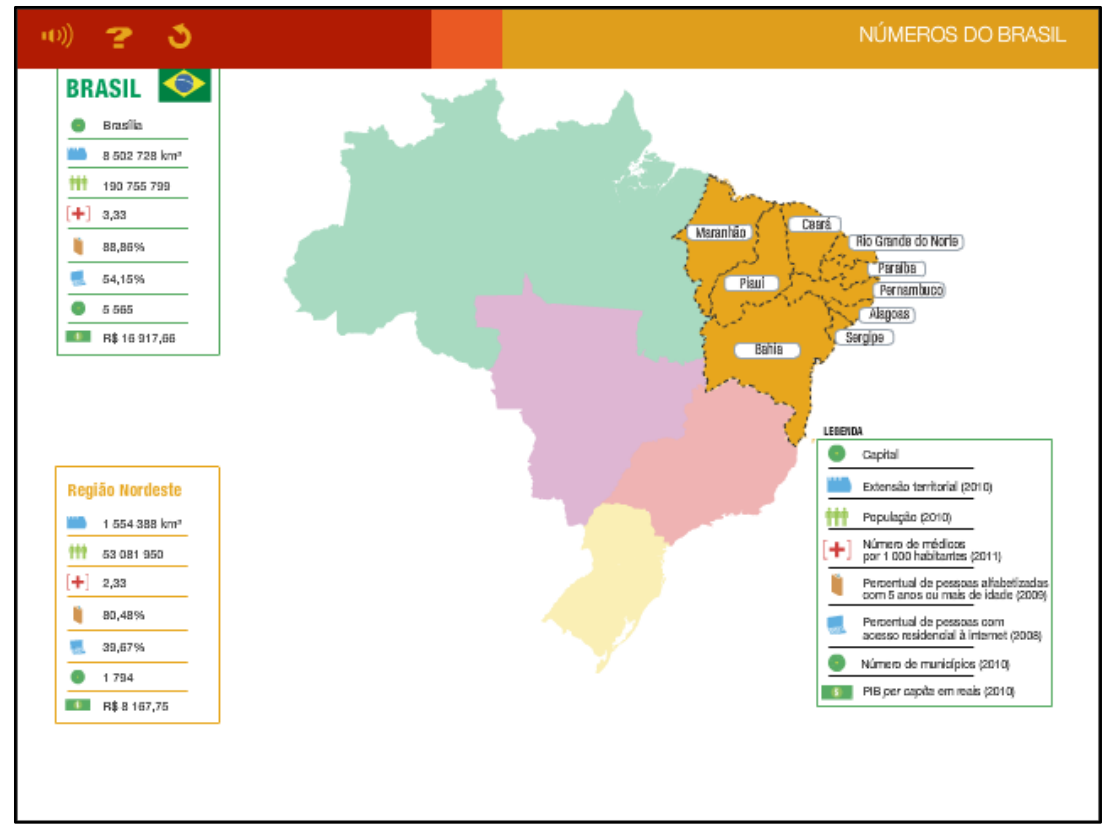

Figura 24: Dados referente à região Nordeste.

Além disso, o aluno pode ter acesso aos dados relacionados a cada um dos estados da região selecionada clicando sobre os mesmos.

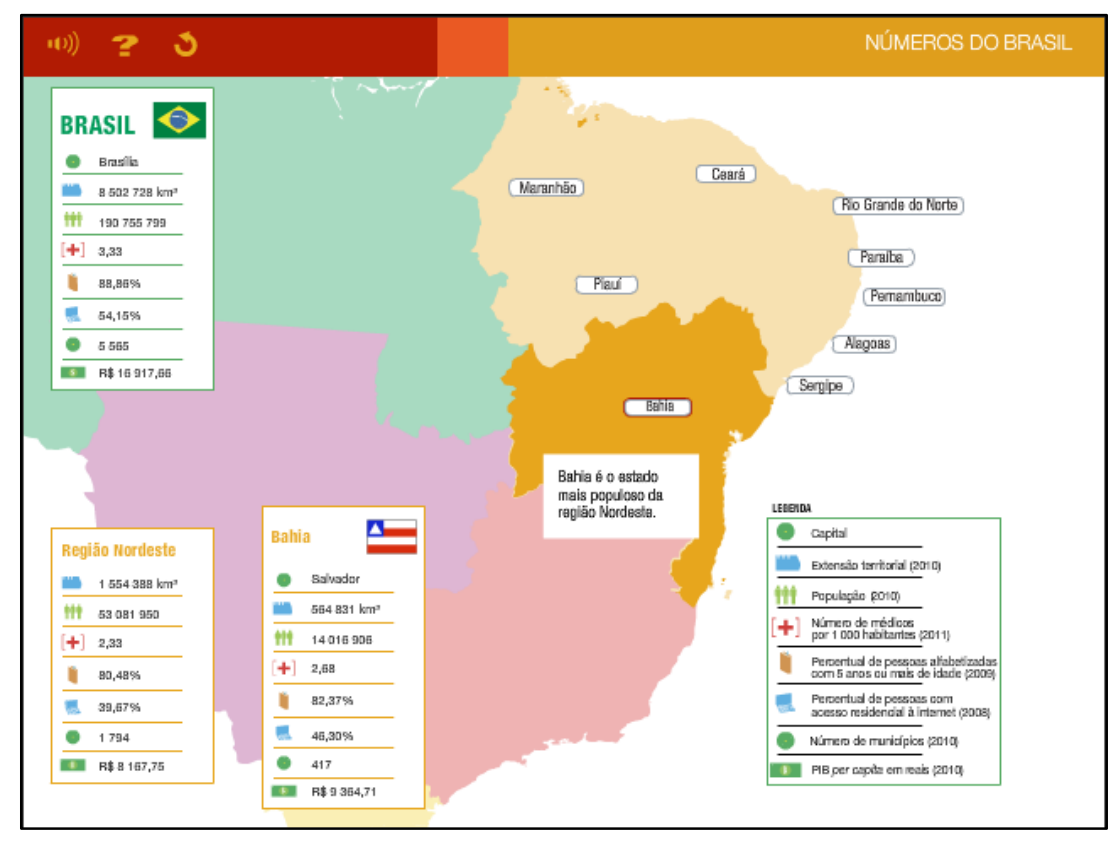

Figura 25: Dados referentes ao estado da Bahia. 


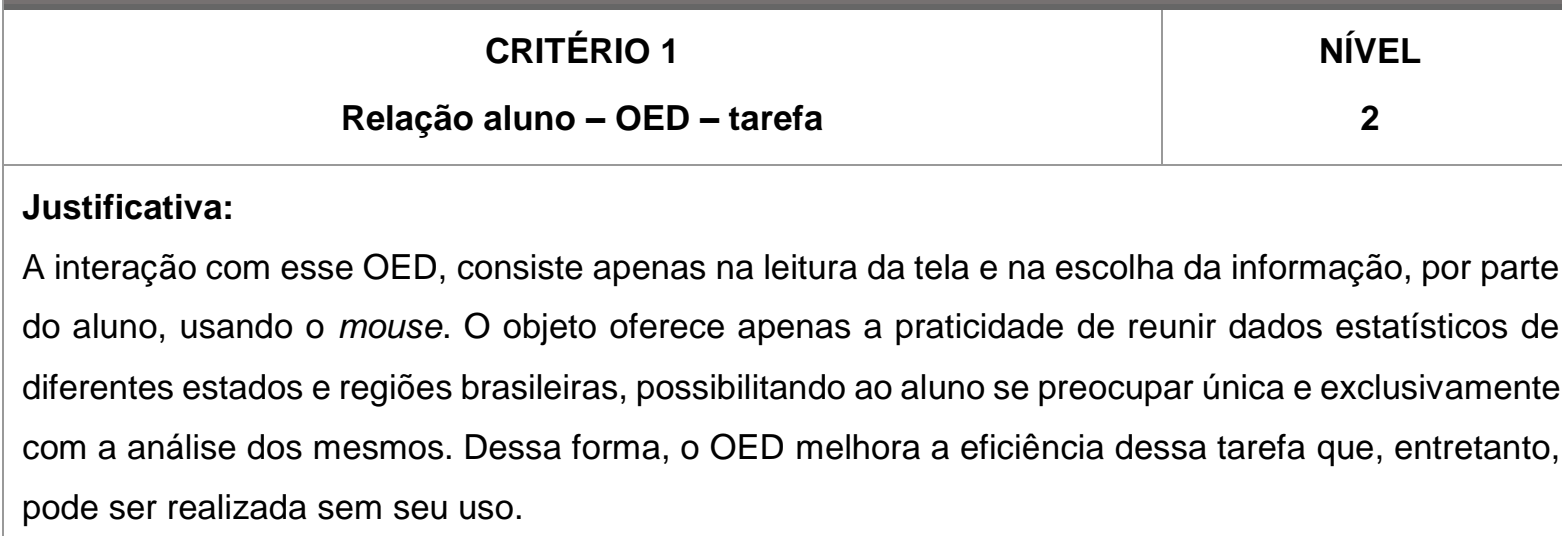

\section{CRITÉRIO 2}

NÍVEL

Mobilização de diferentes registros de representação no OED

2

\section{Justificativa:}

Ao interagir com esse OED, o aluno lida com dois registros: registro numérico (dados estatísticos referentes às regiões e aos estados brasileiros) e registro figural 'especial' (mapa para a localização geográfica). O professor pode, nesse caso, propor aos alunos que representem os dados correspondentes a uma determinada variável, em gráficos de barras ou de setores. Isso exigiria realizar a conversão do registro numérico para o registro gráfico, como também facilitaria a análise e comparação dos dados estatísticos presentes.

\section{CRITÉRIO 3}

Interdisciplinaridade e contextualização

NÍVEL

4

\section{Justificativa:}

É comum os meios de comunicação divulgarem cotidianamente dados e informações a respeito do território brasileiro e de sua população e é essencial para a formação do aluno que ele desenvolva competência para leitura, interpretação e análise desses dados e informações. O OED Números do Brasil coloca os alunos em contato com dados que são fruto de levantamentos realizados pelo IBGE e a comparação e análise destes pode motivá-los, com ou sem estímulo do professor, a buscar respostas à algumas perguntas como, por exemplo:

- Por que o percentual de pessoas com acesso residencial à internet é tão baixo nas regiões Norte e Nordeste?;

- Por que a região Sudeste é a que possui o maior número de médicos para cada 1.000 habitantes?

Tais questões foram levantadas a partir de dados estatísticos e as respostas para as mesmas se situam no âmbito de disciplinas como História e Geografia. A Língua Portuguesa se faz presente tanto na interpretação das informações obtidas, quanto no modo segundo o qual o aluno se expressa para responder às perguntas. Assim, o contexto que permeia esse objeto é significativo e tem potencial para que, a partir dele, sejam desencadeadas propostas interdisciplinares. 


\subsection{Quadriláteros}

O OED Quadriláteros é um jogo eletrônico educativo destinado ao $8^{\circ}$ ano do Ensino Fundamental. Nesse jogo os alunos devem mobilizar os seus conhecimentos acerca das propriedades fundamentais dos paralelogramos e dos trapézios ${ }^{44}$ para que cumpram cada uma das 20 fases que o compõem.

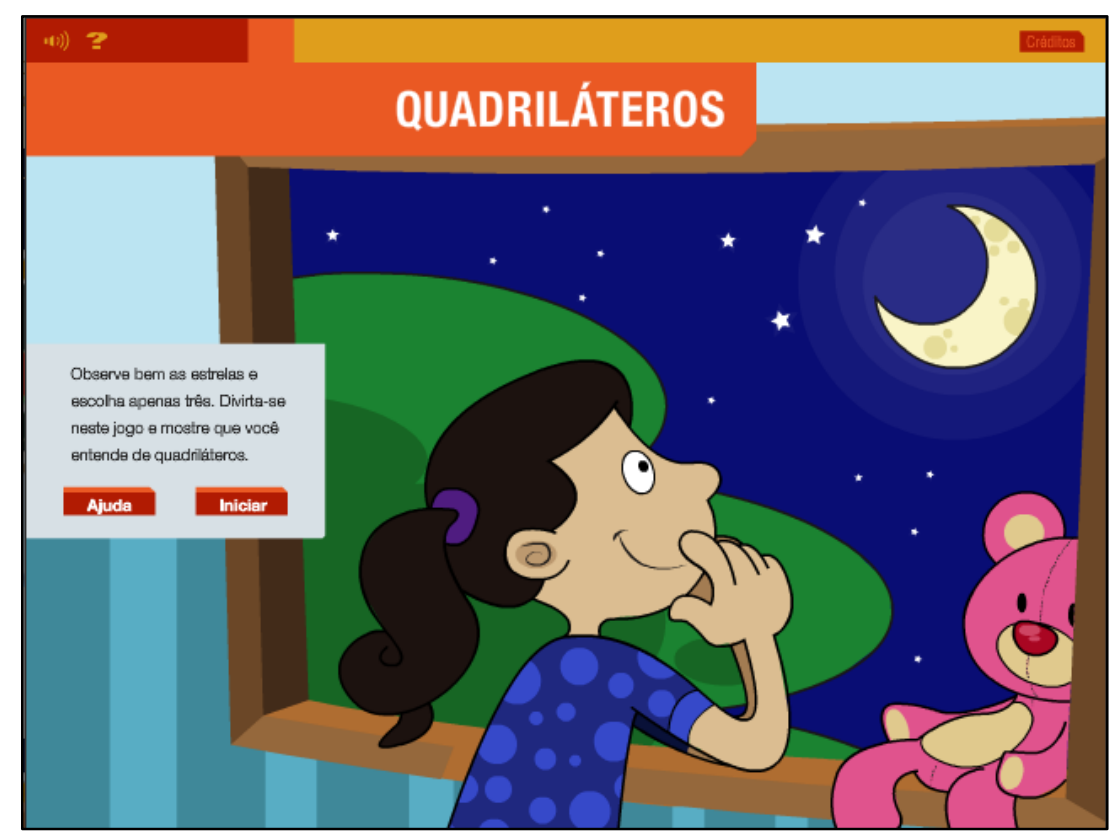

Figura 26: Tela inicial do OED Quadriláteros.

Cada fase é composta por uma malha pontilhada em que estão presentes 5 estrelas fixas. $O$ objetivo é que o aluno forme sobre a malha de cada uma das fases um quadrilátero ${ }^{45}$ seguindo uma determinada instrução e contendo exatamente 3 estrelas em seu interior. São exemplos de instruções que comparecem no jogo: "Desenhe um RETÂNGULO, mas não vale quadrado", "Desenhe um

\footnotetext{
${ }^{44}$ Segundo Bongiovanni (2010), existem duas definições para um trapézio:

Definição 1. Trapézio é um quadrilátero com um par de lados paralelos.

Definição 2. Trapézio é um quadrilátero que apresenta um único par de lados paralelos.

Dessa forma, segundo a Definição 1, um paralelogramo é um trapézio, enquanto que pela Definição 2 não. Esta última é a definição adotada na coleção Vontade de saber matemática de Joamir Souza e Patrícia Moreno Pataro (coleção que incorpora o OED Quadriláteros), e, por esse motivo será adotada neste trabalho.

${ }^{45} \mathrm{Em}$ determinadas fases é possível o aluno formar mais de um quadrilátero contendo exatamente três estrelas em seu interior e atendendo à instrução.
} 
PARALELOGRAMO, mas não vale losango nem retângulo", "Desenhe um LOSANGO, mas não vale quadrado" etc.

Além das instruções, a disposição das estrelas varia de fase para fase, conforme mostram as imagens a seguir:

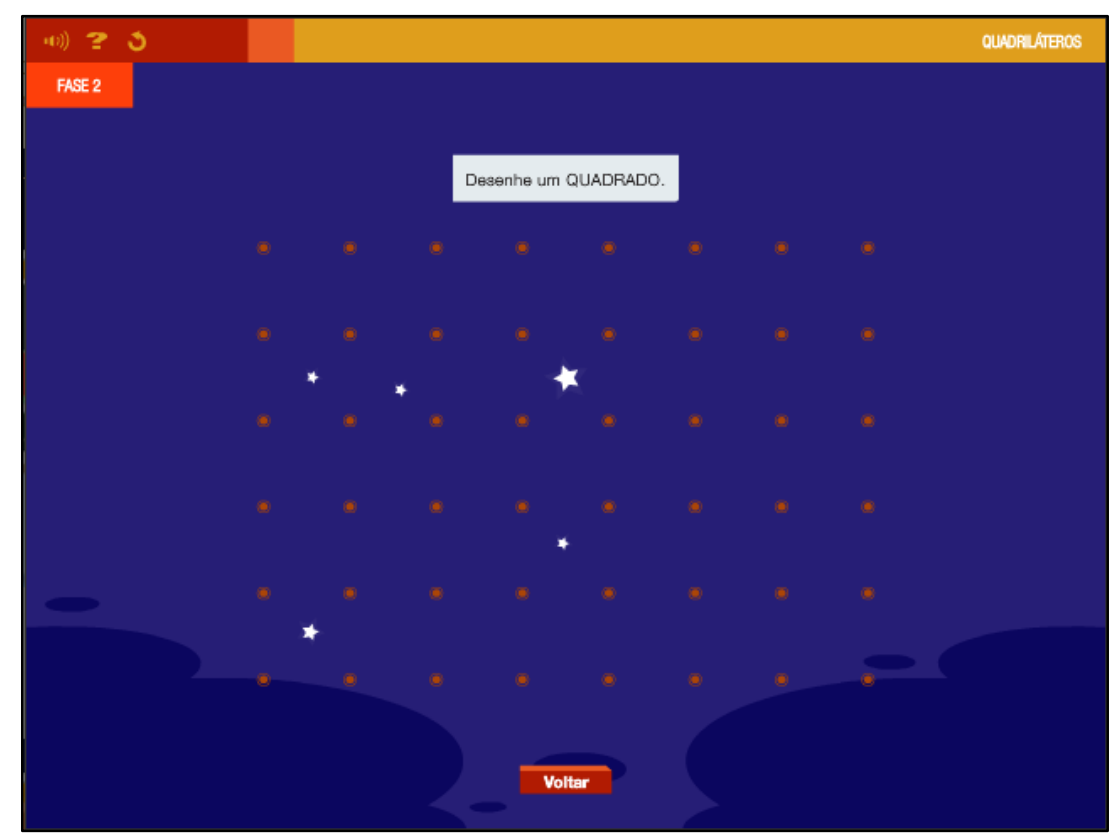

Figura 27: Fase 2 do OED Quadriláteros.

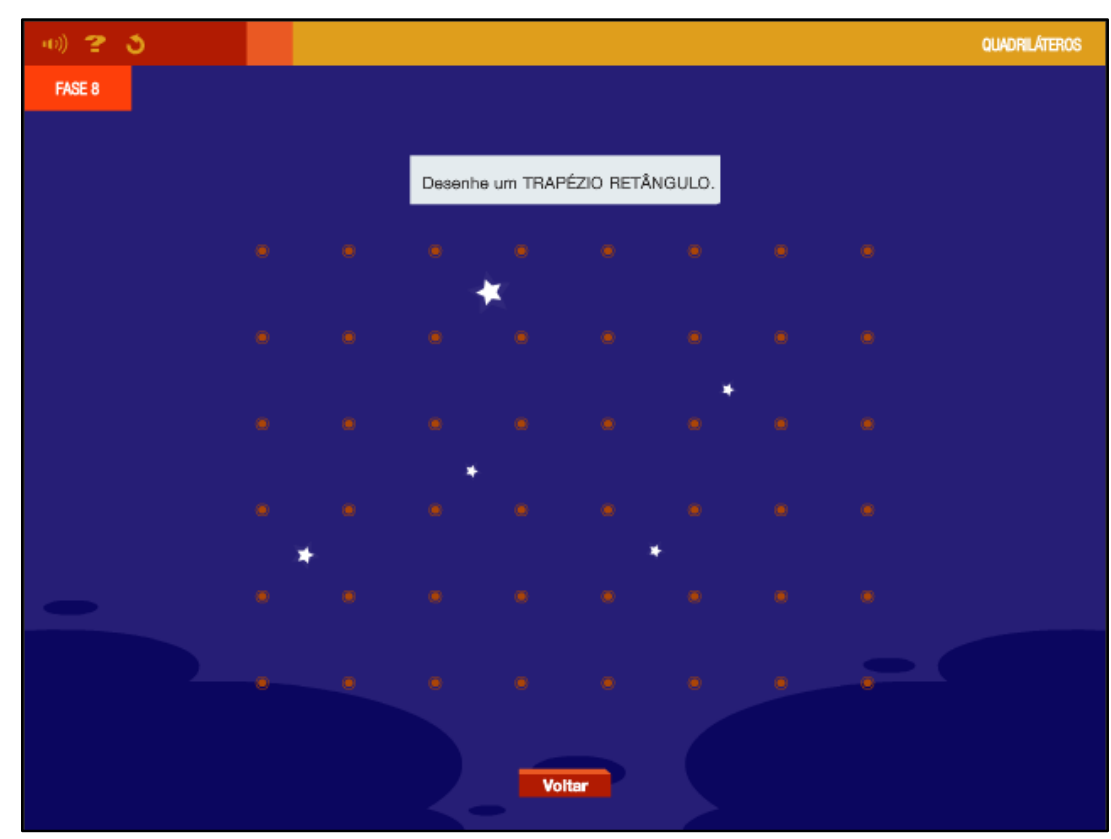

Figura 28: Fase 8 do OED Quadriláteros. 


\begin{tabular}{c|c} 
CRITÉRIO 1 & NÍVEL \\
Relação aluno - OED - tarefa & 4 \\
\hline
\end{tabular}

Justificativa:

Em cada uma das 20 fases que compõem o jogo, O OED desafia o aluno a resolver um problema, tendo, para isso, que percorrer as etapas do ciclo descrição - execução - reflexão - depuração. A descrição engloba tanto o planejamento do aluno - que deve levar em consideração as propriedades do quadrilátero solicitado e a sua posição - como a construção do desenho que é feita, clicando sobre os pontos da malha, segmento a segmento. A execução pelo OED ocorre simultaneamente à construção do desenho e fornece ao aluno o resultado de suas ações. A reflexão está subjacente às etapas da descrição e execução e é por meio dela que o aluno poderá ou não iniciar a atividade de depuração. A atividade de depuração se origina quando a expectativa inicial não é atendida e é estimulada pelo feedback fornecido pelo OED (mensagens como "Devem ficar exatamente 3 estrelas no interior do quadrilátero" ou "Quadrilátero incorreto" aparecem quando o quadrilátero construído pelo aluno não atende às exigências da fase). Nesse caso, o aluno precisa rever sua estratégia ou se compreendeu corretamente os conceitos envolvidos. Retornos que pudessem levar os alunos a compreender que, por exemplo, um paralelogramo é distinto de um trapézio ou que o quadrado, o retângulo e o losango são paralelogramos poderiam contribuir mais para a aprendizagem dos alunos e para o sucesso deles na atividade de depuração.

\section{CRITÉRIO 2}

Mobilização de diferentes registros de representação no OED

NÍVEL

3

\section{Justificativa:}

Os quadriláteros a serem desenhados em cada uma das 20 fases devem seguir determinadas instruções e aí está subjacente a realização da conversão do registro na língua natural (instruções) para o registro figural (desenho dos quadriláteros). Dessa forma, o OED trabalha a conversão desses dois registros, mas apenas em um sentido. Cabe aqui a observação de que o OED não estimula o aluno a justificar o porquê de o desenho feito atender à instrução dada e cabe ao professor nesse caso, incentivá-lo a fazer tal argumentação.

\section{CRITÉRIO 3}

\section{Interdisciplinaridade e contextualização}

NÍVEL

4

\section{Justificativa:}

O contexto proposto permite ir do facto (observação das estrelas no "céu") para o ficto (imaginar que essas estrelas podem ser cercadas pela reunião de segmentos de reta, que formam um quadrilátero). Tal ficto, aliás, pode estimular a realização de um projeto interdisciplinar, envolvendo as disciplinas de Matemática e Ciências, relacionado à disposição das estrelas em algumas constelações.

Quadro 15: Análise do OED Quadriláteros. 


\subsection{Analisando medidas}

O OED Analisando medidas é um simulador proposto para o $8^{\circ}$ ano do Ensino Fundamental. Nele os alunos podem analisar os valores máximo e mínimo além das medidas de tendência central - média aritmética, mediana e moda - de conjuntos de valores referentes à idade, massa ou altura de personagens, podendo o aluno incluir também suas próprias medidas em um personagem editável.

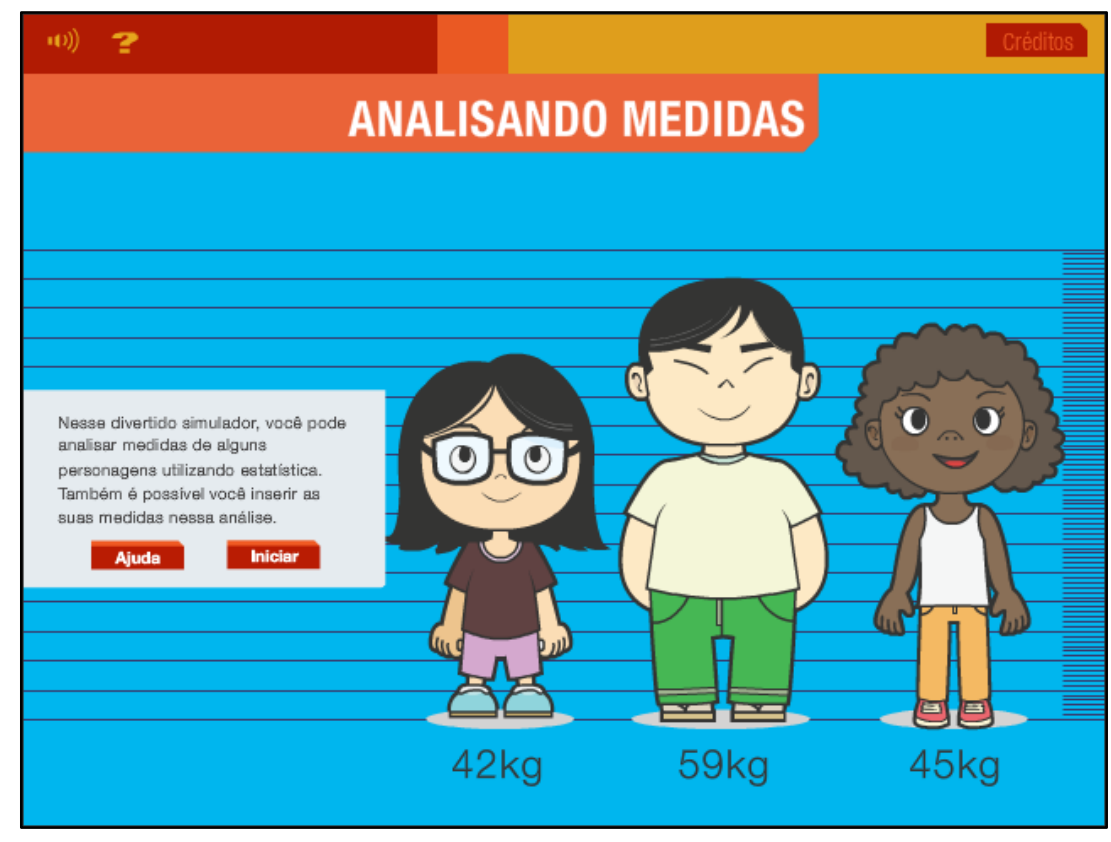

Figura 29: Tela inicial do OED Analisando Medidas.

Para realizar as simulações, os alunos podem escolher de 2 a 6 personagens (incluindo o personagem editável). $O$ objetivo é que eles percebam como as medidas de tendência central variam conforme a escolha dos personagens considerados. Além disso, é possível também utilizar o personagem editável para inserir valores referentes à idade, massa ou altura discrepantes dos demais e observar como a média aritmética, moda e a mediana são afetadas por esses valores.

As figuras, a seguir, exibem algumas situações que podem ser exploradas pelos alunos ao interagir com esse OED: 


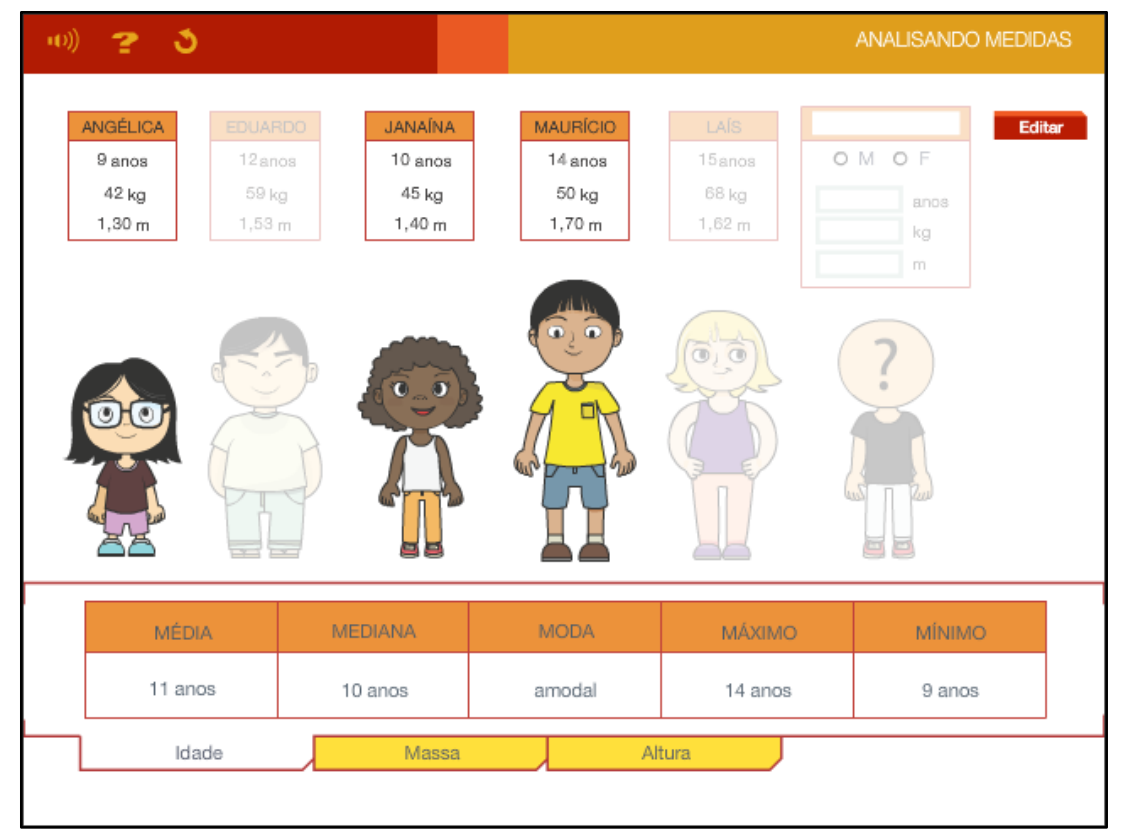

Figura 30: Medidas de tendência central, máximo e mínimo das idades de 3 personagens.

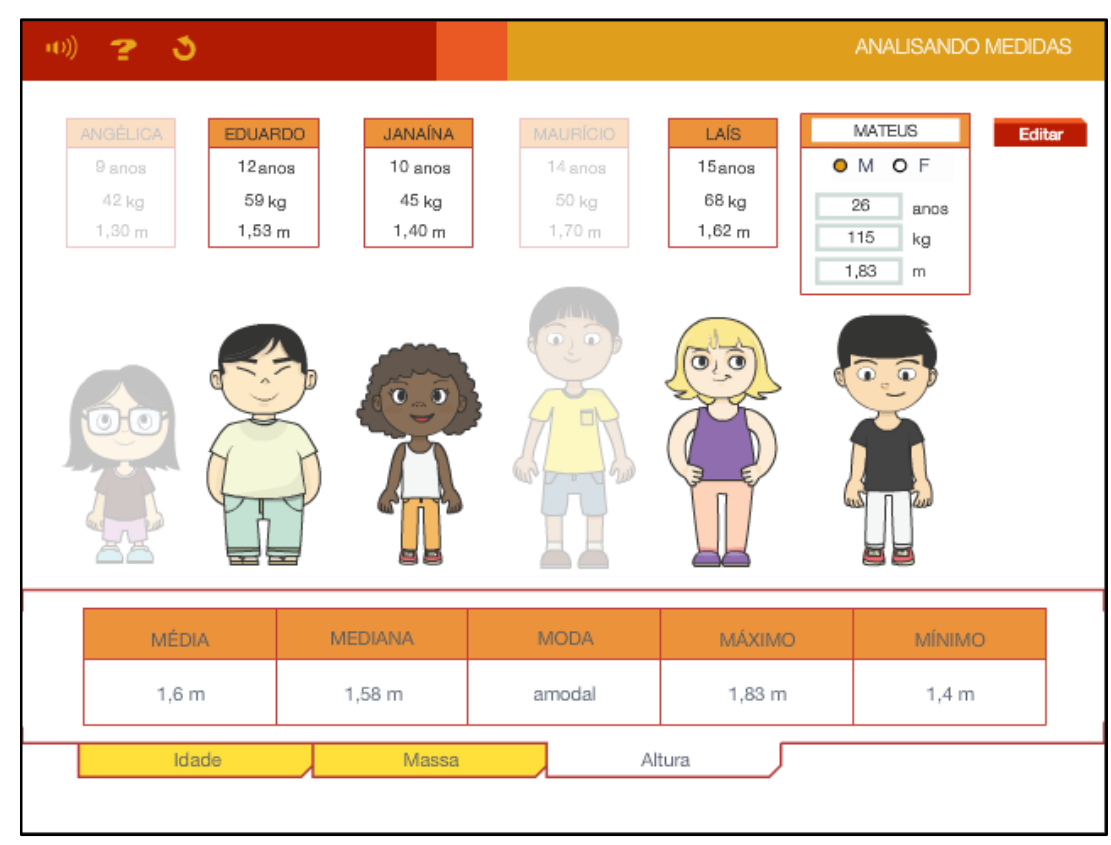

Figura 31: Medidas de tendência central, máximo e mínimo das alturas de 4 personagens, incluindo o personagem editável.

Observa-se também que, por orientação do MEC, os personagens são de diferentes etnias, justamente para evitar que seja dada preferência a uma só etnia, criando estereótipos. 


\begin{tabular}{|c|c|}
\hline CRITÉRIO 1 & NÍVEL \\
Relação aluno - OED - tarefa & 3 \\
\hline
\end{tabular}

Justificativa:

O OED oferece aos alunos - talvez até mesmo sem a intervenção do professor - a oportunidade de investigar e estabelecer conjecturas. Isso porque, a partir da escolha dos personagens, eles podem analisar como se comportam os valores máximo e mínimo além das medidas de tendência central de cada um dos conjuntos de valores: idade, massa ou altura dos personagens selecionados. A partir dessa experiência, podem inferir, por exemplo, qual medida de tendência central melhor representa um conjunto de valores com ou sem dados discrepantes, ou ainda, que é possível a média aritmética assumir um valor diferente daqueles do conjunto de valores que ela representa ou pretende representar.

\section{CRITÉRIO 2}

\section{Mobilização de diferentes registros de representação no OED}

NÍVEL

2

\section{Justificativa:}

O OED trabalha com o registro numérico tabular (números que representam as idades e as medidas de massa ou altura dos personagens) e o registro da língua natural (pois comparecem as palavras como "máximo", "mínimo", "moda", "amodal", "mediana" e "média"), sem, no entanto, estabelecer qualquer relação entre os mesmos.

\section{CRITÉRIO 3}

\section{Interdisciplinaridade e contextualização}

NÍVEL

3

\section{Justificativa:}

Observa-se que há uma tentativa de articular o eixo de Grandezas e Medidas e o de Tratamento da Informação, pois os conjuntos de valores sobre os quais são determinados o máximo e o mínimo, além das medidas de tendência central, são constituídos essencialmente por números que representam idades, medidas de massa ou medidas de altura. Entretanto, tais conjuntos de valores comparecem desvinculados de uma situação em que seja necessário, por exemplo, analisar a média aritmética para tomar alguma decisão. Cabe ao professor, nesse caso, enriquecer a proposta do OED, propondo questões como:

- Se para participar de um jogo de basquete a média de altura do time deve ser superior a 1,5 m, que personagens devem ser escolhidos para fazer parte de um time com 3 integrantes? Nesse time poderá ter alguém com altura inferior a $1,5 \mathrm{~m}$ ?

Assim, pode-se dizer que o contexto presente é significativo por ser intramatemático e possibilitar ao professor colocar seus alunos diante de circunstâncias em que analisar essas medidas estatísticas é importante.

Quadro 16: Análise do OED Analisando medidas. 


\subsection{Sorteando bolas}

O OED Sorteando bolas - destinado ao 8ํano do Ensino Fundamental - é um simulador de sorteios aleatórios de bolas coloridas com reposição ${ }^{46}$. Nele é possível o aluno comparar a probabilidade de uma determinada cor de bola a ser sorteada com o resultado do experimento.

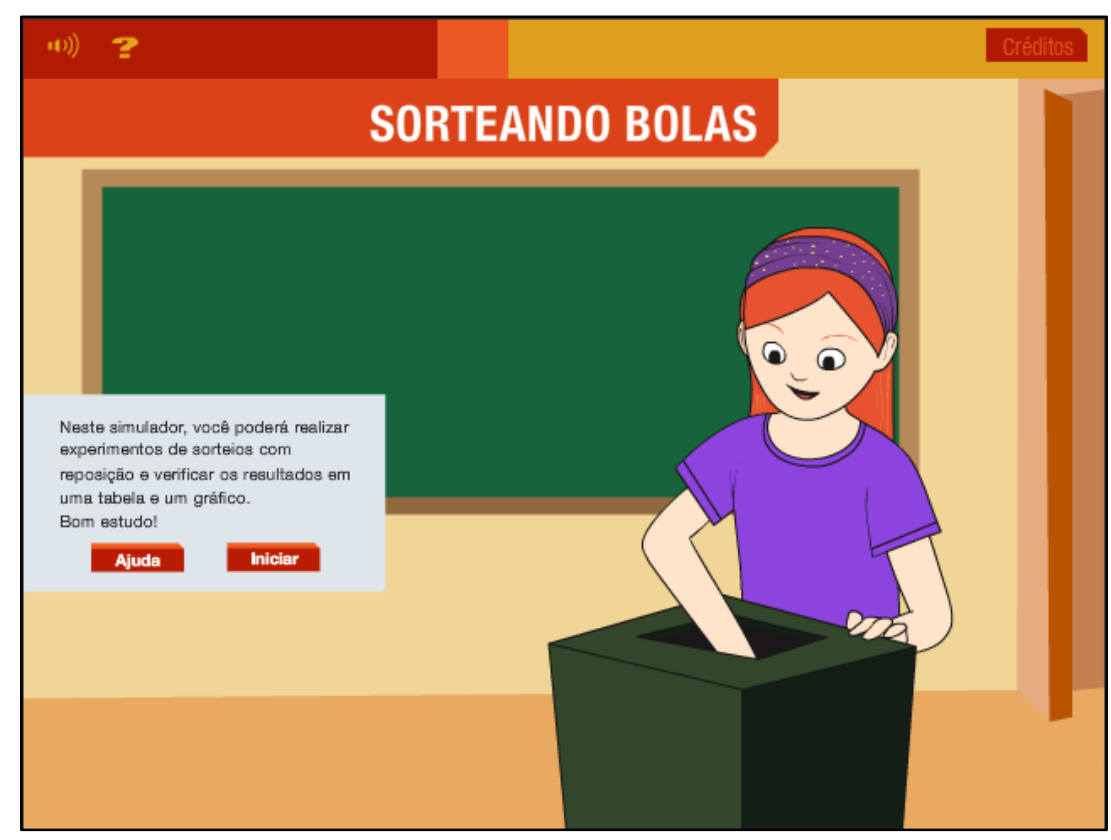

Figura 32: Tela inicial do OED Sorteando bolas.

Para realizar as simulações, o aluno deve inicialmente inserir na urna uma quantidade qualquer de bolas de cada cor. À disposição dele há cinco cores de bolas ${ }^{47}$ - vermelha, verde, azul, amarela e laranja - das quais ele pode, no máximo, inserir 99 de cada cor na urna. Além disso, é possível escolher a quantidade de sorteios com reposição a serem realizados: 1, 5, 10, 50 ou 100.

O objetivo é que os alunos possam realizar várias simulações variando tanto a quantidade de bolas coloridas quanto a quantidade de sorteios, e que verifiquem por meio da tabela ou do gráfico que, de maneira geral, quanto maior a quantidade de

\footnotetext{
${ }^{46}$ Sorteio com reposição é aquele no qual após retirar uma bola, sua cor é anotada e ela é devolvida à urna.

47 Nas orientações para o professor trabalhar esse OED chama-se a atenção para o fato de que é importante comentar com os alunos que as bolas diferem apenas pela cor e que, portanto, a probabilidade de qualquer bola ser sorteada é a mesma.
} 
sorteios, mais próximo o percentual de bolas sorteadas de cada cor estará do percentual de bolas da respectiva cor colocadas na urna. A figura, a seguir, exibe o resultado de uma dessas simulações:

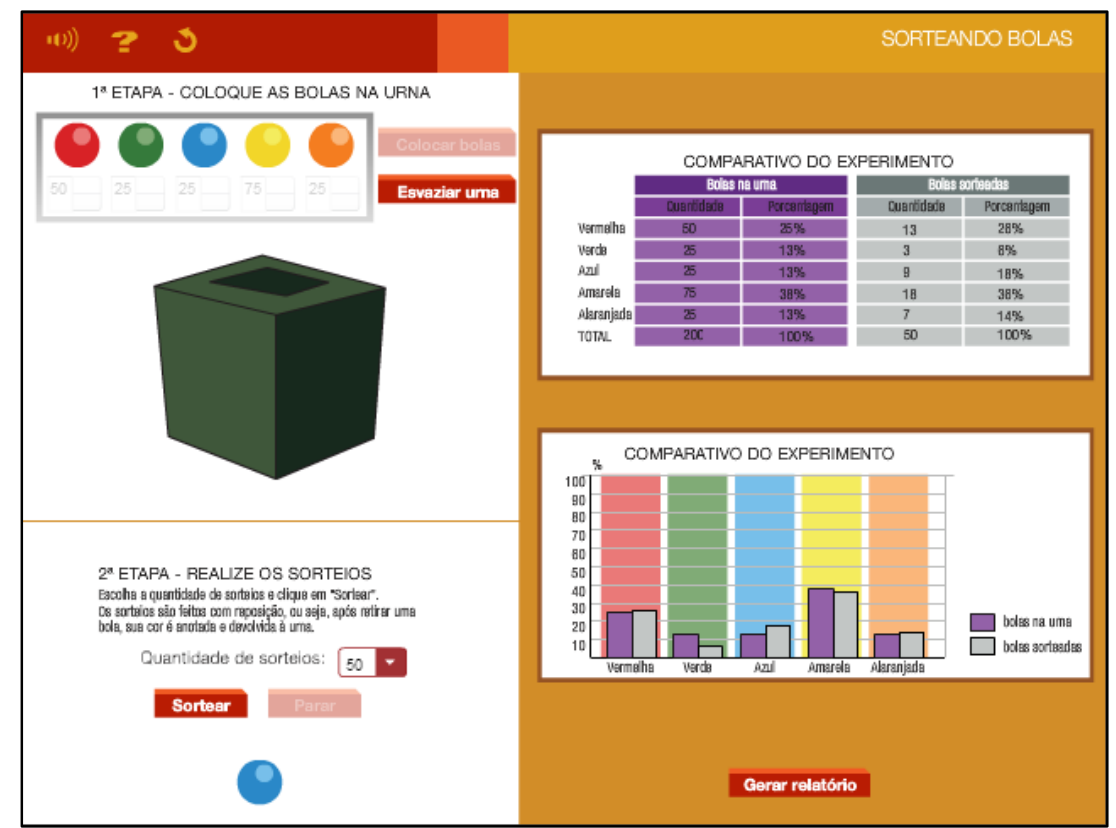

Figura 33: Resultado da simulação de 50 sorteios com reposição de bolas em uma urna que contém 50 bolas vermelhas, 25 verdes, 25 azuis, 75 amarelas e 25 laranjas.

Por fim, ainda é possível o aluno gerar e imprimir o relatório com o resultado do experimento:

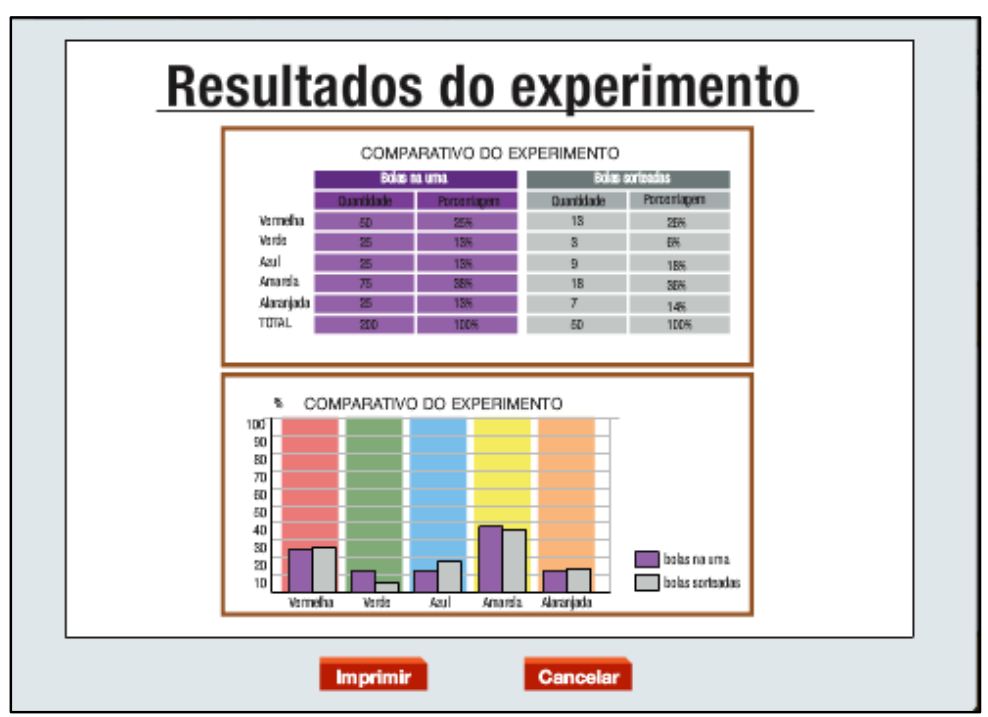

Figura 34: Relatório do experimento ilustrado na figura 33. 
Esse OED contribui para que o aluno trabalhe o pensamento não determinístico - próprio de situações em que a incerteza está presente - e consequentemente compreenda que a probabilidade é uma medida dessa incerteza.

\begin{tabular}{|c|c|}
\hline \multicolumn{2}{|l|}{ Análise do OED Sorteando bolas } \\
\hline & \\
\hline \multicolumn{2}{|c|}{$\begin{array}{l}\text { Justificativa: } \\
\text { O OED contribuiu para que aluno assuma uma postura investigativa ao permitir que ele varie o } \\
\text { número de bolas de cada cor a serem colocadas na urna ou escolher o número de sorteios com } \\
\text { reposição a serem realizados. Além disso, ao comparar a probabilidade com o percentual de bolas } \\
\text { de determinada cor sorteadas, ele pode estabelecer conjecturas, como por exemplo: quanto maior a } \\
\text { quantidade de bolas de uma determinada cor estiverem na urna, maior é a probabilidade dessa cor } \\
\text { ser sorteada ou, ainda, quanto maior a quantidade de sorteios, mais próximo o percentual de bolas } \\
\text { sorteadas de cada cor estará do percentual de bolas da respectiva cor colocadas na urna. }\end{array}$} \\
\hline $\begin{array}{c}\text { CRITERIO } 2 \\
\text { Mobilização de diferentes registros de representação no OED }\end{array}$ & \\
\hline \multicolumn{2}{|c|}{$\begin{array}{l}\text { Justificativa: } \\
\text { O OED trabalha sem, no entanto, estabelecer relações entre eles, com quatro registros de } \\
\text { representações diferentes: registro numérico tabular (tabelas com as quantidades e percentuais de } \\
\text { bolas na urna e de bolas sorteadas em um determinado experimento), registro gráfico (gráfico de } \\
\text { barras duplas verticais que permite comparar os percentuais de bolas na urna e o de bolas sorteadas } \\
\text { em um determinado experimento), registro da língua natural (pois comparece a palavra } \\
\text { "porcentagem") e registro figural 'especial' (caixas e bolas). }\end{array}$} \\
\hline Interdisciplinaridade e contextualização & NÍVEL \\
\hline \multicolumn{2}{|c|}{$\begin{array}{l}\text { Justificativa: } \\
\text { O contexto presente nesse OED é significativo, pois situações envolvendo sorteios são bastante } \\
\text { presentes no cotidiano - como por exemplo, para contemplar alguém com um prêmio, determinar os } \\
\text { enfrentamentos entre os times participantes de um campeonato de futebol, escolher o representante } \\
\text { de uma turma de alunos etc - e também devido à sua importância histórica, afinal a origem do } \\
\text { pensamento probabilístico está vinculada aos jogos de azar. Além disso, tais situações contribuem, } \\
\text { também, para que o aluno reconheça a incerteza a elas inerente e, com isso, atribua significado ao } \\
\text { conceito de probabilidade. }\end{array}$} \\
\hline
\end{tabular}

Quadro 17: Análise do OED Sorteando bolas. 


\subsection{Jogo dos aquários}

O OED Jogo dos aquários, concebido para os alunos do 9ª ano do Ensino Fundamental, é um jogo eletrônico educativo no qual o aluno, em cada fase, deve desenvolver estratégias para obter nos aquários a quantidade de líquido indicada.

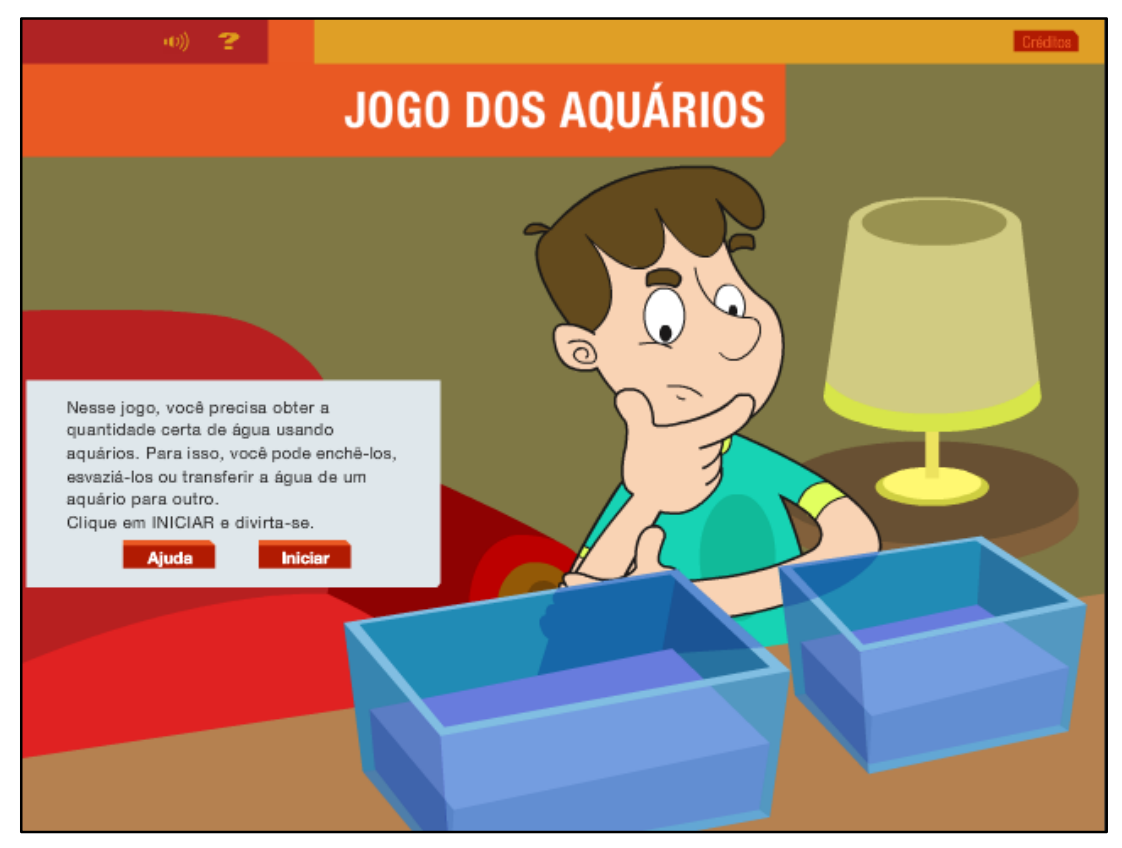

Figura 35: Tela inicial do OED Jogo dos aquários.

Para atingir o objetivo, em cada uma das fases, o aluno deve calcular o volume dos aquários cujos formatos lembram um paralelepípedo e, em seguida, esvaziar, encher ou transferir o líquido de um aquário para o outro de modo a obter a quantidade indicada. Subjaz a esse processo o fato de que o aluno deve converter medidas em decímetro cúbico $\left(\mathrm{dm}^{3}\right)$ para litro $(\mathrm{L})$ ou vice-versa, uma vez que, as medidas das arestas dos aquários são fornecidas na unidade decímetro (dm) e a quantidade de líquido é indicada na unidade litro $(L)$.

O jogo possui 7 fases. As figuras, a seguir, ilustram as situações a serem enfrentadas pelos alunos em duas delas: 


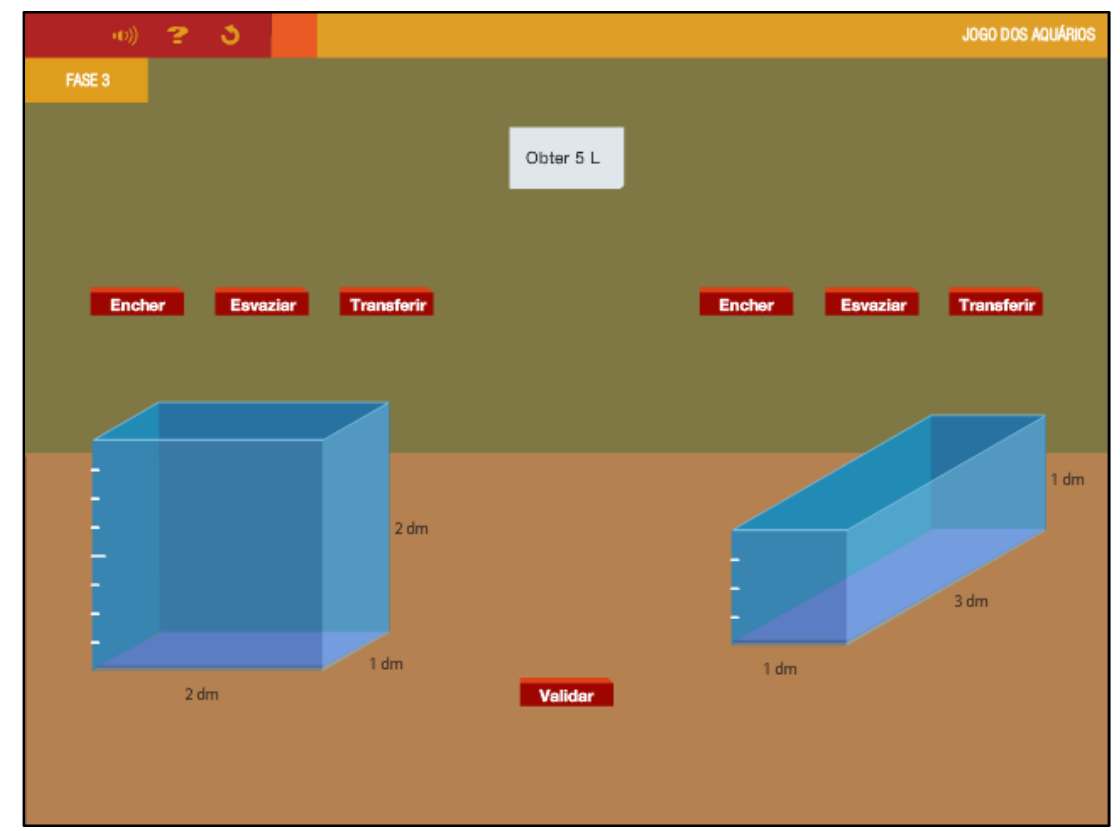

Figura 36: Situação da fase 3 do jogo.

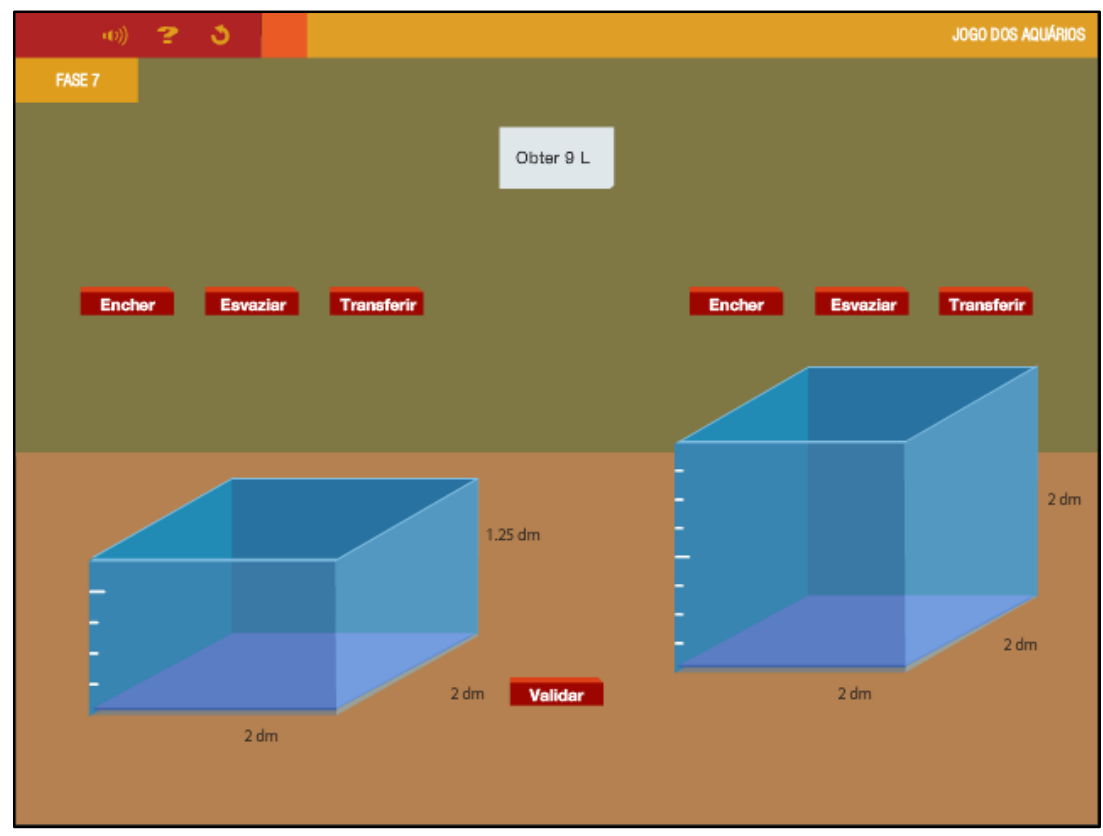

Figura 37: Situação da fase 7 do jogo.

Uma maneira de ampliar as possibilidades desse jogo é sugerida nas orientações ao professor e consiste em solicitar aos alunos que registrem o número de movimentos (equivalente ao número de cliques nos botões) necessários para superar cada fase e incentivá-los a tentar reduzir esse número. 


\subsection{Juro simples e juro composto}

O OED Juro simples e juro composto, destinado ao $9^{\circ}$ ano do Ensino Fundamental, é um simulador que permite aos alunos analisarem, por meio de gráficos, o montante resultante de aplicações financeiras sujeitas a juro simples e a juro composto. Na interação com esse objeto, é possível que os alunos compreendam a diferença entre esses dois regimes financeiros e relacionem os gráficos correspondentes ao montante no sistema de juro simples e juro composto, aos de uma função afim e exponencial, respectivamente.

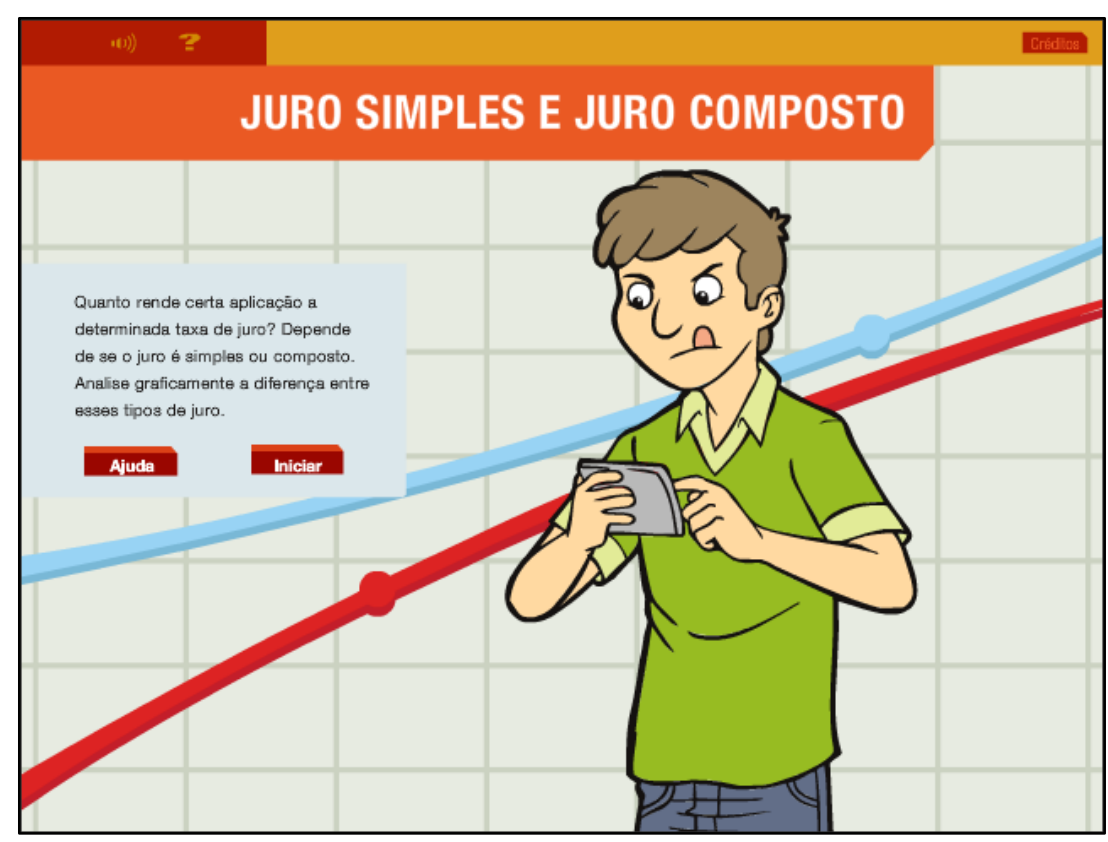

Figura 38: Tela inicial do OED Juro simples e juro composto.

O capital inicial considerado nas simulações é sempre $R \$ 1.000,00$, podendo 0 aluno escolher a taxa de juro mensal e o tempo de aplicação que pode ser de 12, 24 ou 36 meses. Uma vez escolhidos os valores, o OED gera no mesmo par de eixos, os gráficos correspondentes às aplicações sujeitas tanto a juro simples como a juro composto. É possível ainda, o aluno "navegar" pelos gráficos para verificar o montante resultante do investimento no decorrer do tempo. 
As figuras, a seguir, mostram simulações de aplicações financeiras que podem ser realizadas com o auxílio desse OED:

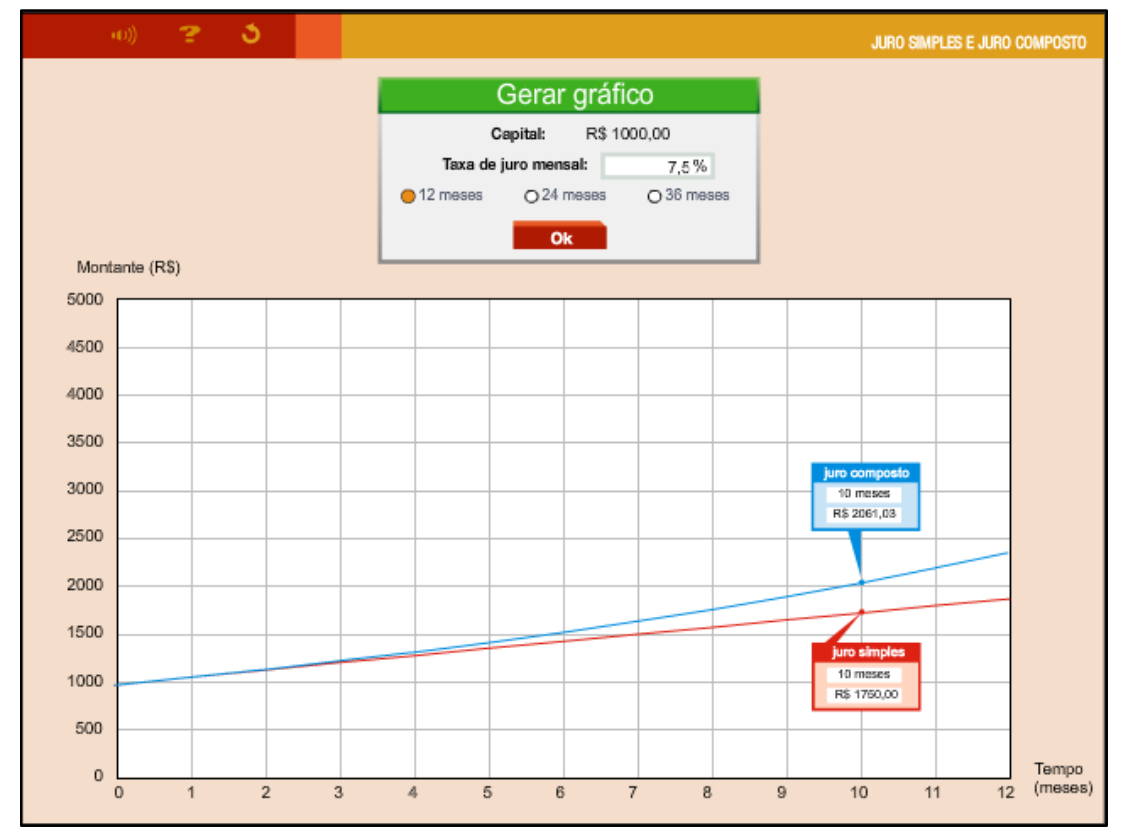

Figura 39: Gráficos dos comportamentos do montante no decorrer do tempo de uma aplicação de $\mathrm{R} \$$ $1.000,00$ sujeita a uma taxa de juro (simples e composto) mensal de $7,5 \%$ no decorrer de 12 meses.

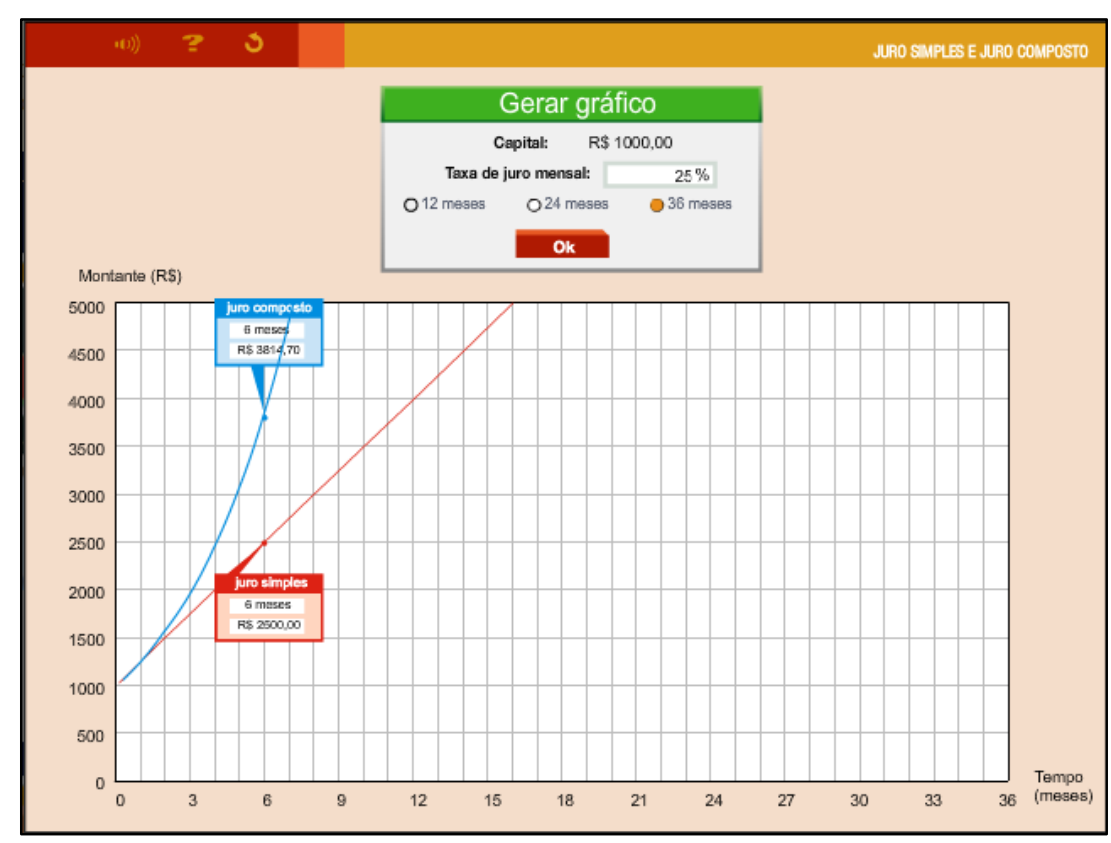

Figura 40: Gráficos dos comportamentos do montante no decorrer do tempo de uma aplicação de $\mathrm{R} \$$ $1.000,00$ sujeita a uma taxa de juro (simples e composto) mensal de $25 \%$ no decorrer de 36 meses. 


\begin{tabular}{|c|c|} 
CRITÉRIO 1 & NÍVEL \\
Relação aluno - OED - tarefa & 3 \\
\hline
\end{tabular}

Justificativa:

A partir da interação com esse OED o aluno pode, por exemplo, observar que o capital sujeito a juro simples cresce mais lentamente do que o mesmo capital sujeito a juro composto ou ainda que, no primeiro caso, a taxa de crescimento é constante enquanto no segundo, a taxa de crescimento é exponencial. Em virtude disso, considera-se que o objeto permite ao aluno investigar e, consequentemente, estabelecer conjecturas.

\section{CRITÉRIO 2}

Mobilização de diferentes registros de representação no OED

NÍVEL

4

\section{Justificativa:}

O OED trabalha com três registros de representação: registro gráfico (gráficos correspondentes à variação do montante no decorrer do tempo de um capital aplicado a juro simples ou composto), registro numérico (dados numéricos) e registro da língua natural (referência às mensagens textuais "juro simples" e "juro composto"). Quando o aluno escolhe o valor do capital inicial, a taxa de juro e o tempo de aplicação o OED realiza a conversão para o registro gráfico. Por outro lado, ao passar o mouse sobre um gráfico, o aluno pode visualizar o tempo de aplicação e o respectivo valor do montante, havendo aí uma conversão do registro gráfico para numérico, realizada pelo OED.

A intervenção do professor é essencial se houver a pretensão de que o aluno entenda o gráfico gerado como sendo o gráfico de uma função, podendo então, ele próprio realizar as conversões.

\begin{tabular}{|l|c|}
\multicolumn{1}{|c|}{ CRITÉRIO 3} & NíVEL \\
\multicolumn{1}{|c|}{ Interdisciplinaridade e contextualização } & 3 \\
\hline Justificativa: \\
No cotidiano, são inúmeras as situações que envolvem juros, como por exemplo, nas compras a \\
prazo, financiamento de imóveis, empréstimos bancários, aplicações financeiras etc. Avaliar sob que \\
condições essas operações financeiras são mais ou menos vantajosas passa, necessariamente, pelo \\
estudo de como o capital devido ou investido evolui ao longo do tempo e subjaz a essa análise o tipo \\
de juro envolvido. Além disso, o contexto proposto permite ao aluno relacionar o comportamento de \\
um capital submetido a juro simples ou composto com partes do gráfico das funções afim e \\
exponencial respectivamente, ou seja, possibilita ao aluno relacionar significados conceituais \\
internos à própria Matemática. Em virtude disso, considera-se que o contexto proposto é significativo, \\
porém não a ponto de desencadear uma proposta interdisciplinar.
\end{tabular}

Quadro 19: Análise do OED Juro simples e composto. 


\subsection{Jogo dos arcos de circunferência}

O OED Jogo dos arcos de circunferência destinado ao $9^{\circ}$ ano do Ensino Fundamental, é um jogo eletrônico educativo no qual o aluno é estimulado a realizar estimativas sobre a medida de um ângulo e o comprimento de um arco.

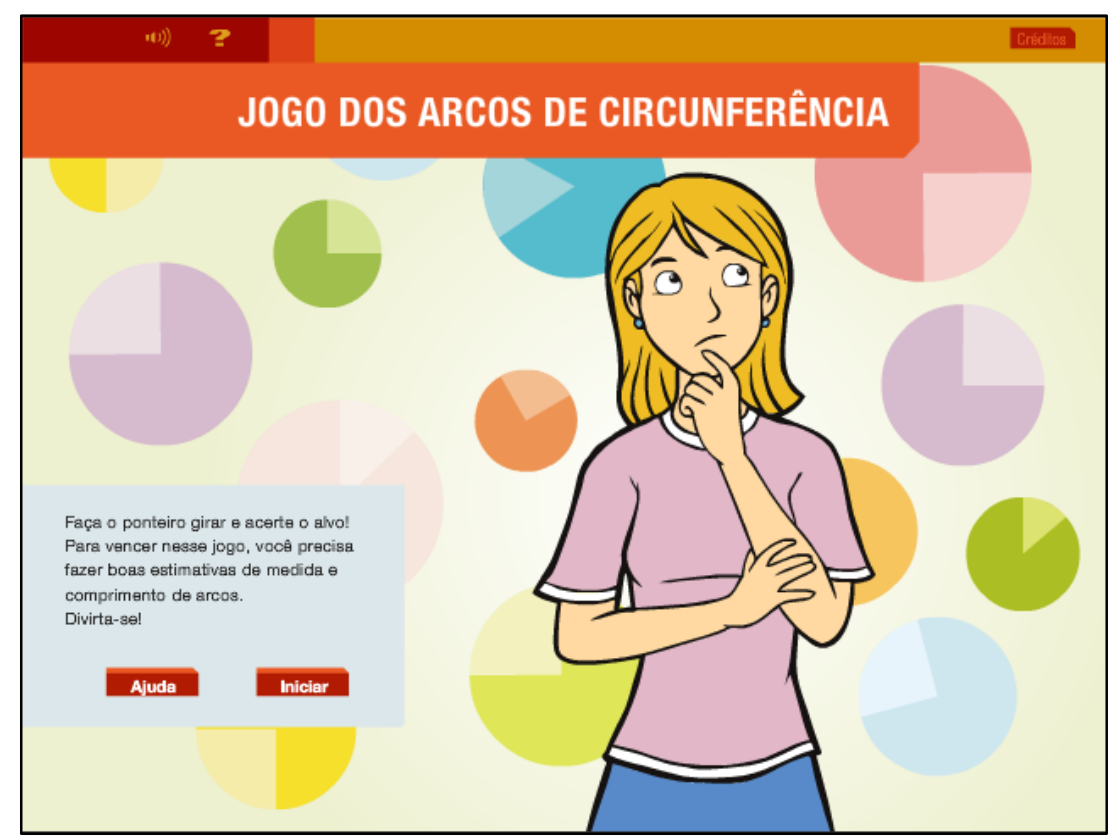

Figura 41: Tela inicial do OED Jogo dos arcos de circunferência.

Nesse jogo, o aluno deve movimentar um ponteiro - fornecendo estimativas para o valor do ângulo ou para o comprimento do arco e o sentido do giro (horário ou anti-horário) - de modo a acertar o alvo. Uma das extremidades do ponteiro coincide com o centro da circunferência e a outra com um de seus pontos. Já o alvo está sobre a circunferência e possui duas cores: amarelo (15 pontos) e vermelho (30 pontos $)^{48}$. A parte vermelha do alvo está entre duas partes amarelas e todas têm o mesmo tamanho (ver figuras 33 e 34 ).

\footnotetext{
48 Toda estimativa é realizada com base em um referencial. Por exemplo, ao estimar a medida do ângulo que o ponteiro deve girar para atingir o alvo, a referência do aluno é a medida do ângulo de uma volta $\left(360^{\circ}\right)$. No entanto para estimar a medida do arco de circunferência, o aluno não possui referencial - comprimento da circunferência que contém o respectivo arco - o que acaba obrigando-o a encontrar essa medida por tentativa e erro.
} 
Ao iniciar o jogo, o aluno pode escolher entre os níveis "iniciante" e "avançado". O que diferencia um nível do outro é o tamanho das partes do alvo: maior no nível "iniciante" e menor no nível "avançado".

Tanto o nível "iniciante" como o "avançado" possui 3 fases. Para cumprir cada uma delas os alunos devem em, no máximo, 5 tentativas obter 100 pontos. As figuras, a seguir, ilustram situações a serem enfrentadas por eles em fases: uma delas do nível "iniciante" e a outra do nível "avançado":

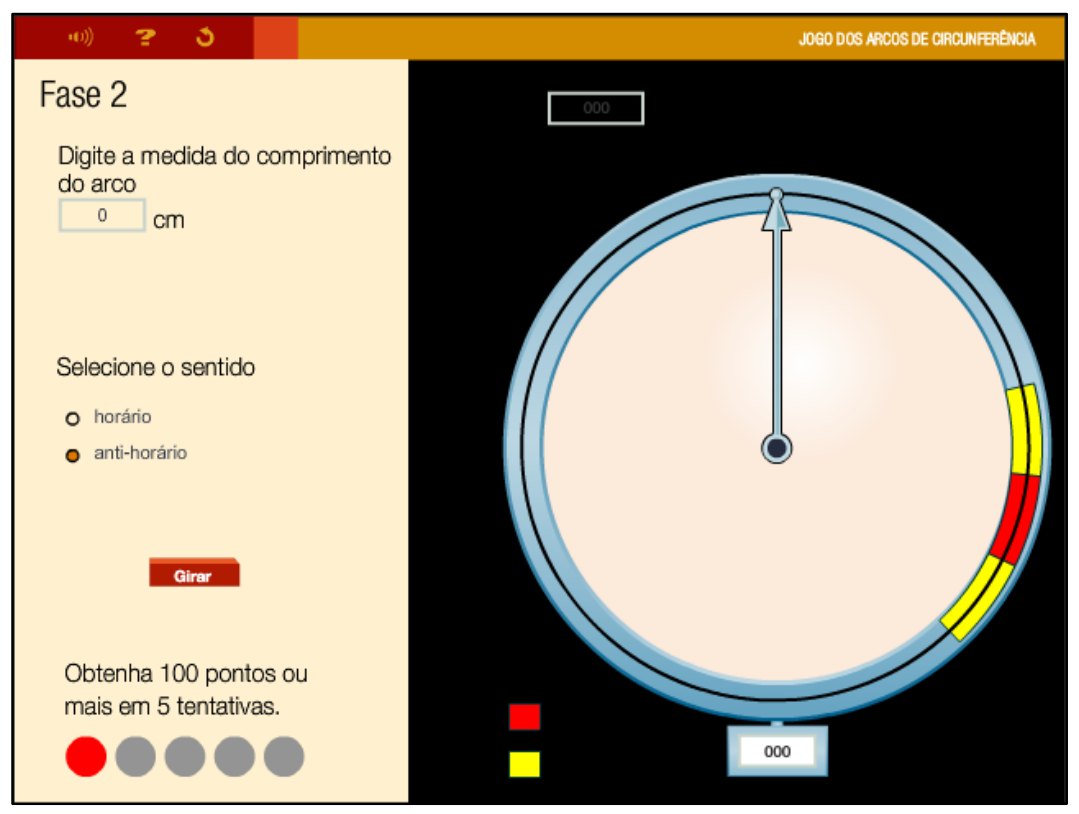

Figura 42: Fase 2 do nível "iniciante" do OED Jogo dos arcos de circunferência.

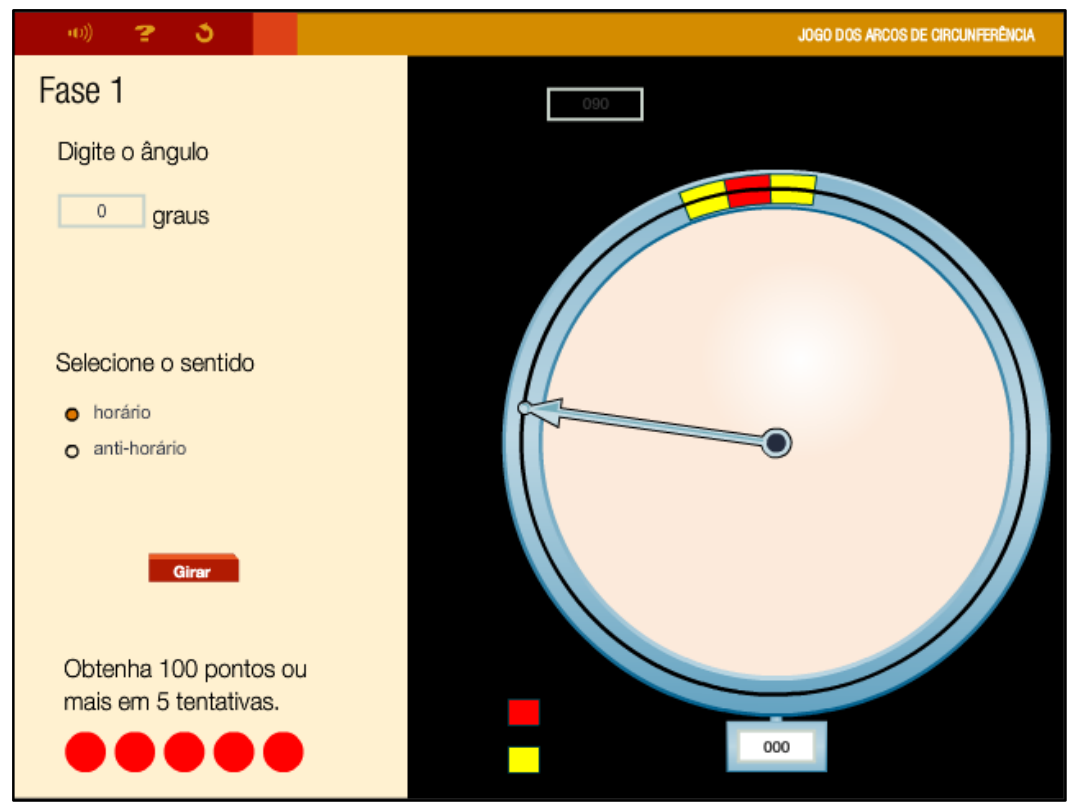

Figura 43: Fase 1 do nível "avançado" do OED Jogo dos arcos de circunferência. 
Na primeira fase de cada nível o aluno trabalha com estimativas de medidas de ângulo e nas demais fases com estimativas de comprimento de arcos. Após cumprir as 3 fases do nível "iniciante ou "avançado", o OED gera uma tabela com a pontuação obtida pelo aluno em cada uma das fases e a pontuação total.

\section{Análise do OED Jogo dos arcos de circunferência}

\begin{tabular}{|c|c|} 
CRITÉRIO 1 & NÍVEL \\
Relação aluno - OED - tarefa & 4 \\
\hline
\end{tabular}

\section{Justificativa:}

O OED desafia os alunos ao colocá-los diante de circunstâncias em que devem desenvolver estratégias para estimar medidas de comprimento de arcos ou de ângulo. Para superar cada fase, eles percorrem as etapas do ciclo descrição - execução - reflexão - depuração. A descriçãa está presente, quando o aluno digita o valor que estimou para a medida do comprimento do arco ou para a medida do ângulo e escolhe o sentido do giro do ponteiro. A execução consiste no movimento do ponteiro e nos valores de comprimento ou ângulos que variam conforme o movimento. A reflexão está subjacente às etapas de descrição e execução, podendo levar ou não o aluno a ingressar na atividade de depuração. A atividade de depuração, por sua vez, ocorre quando o aluno após as 5 tentativas não alcançou a pontuação mínima de 100 pontos, tendo, nesse caso, que refinar suas estimativas de modo a acertar a parte vermelha do alvo o maior número de vezes. A própria natureza da tarefa, nesse caso, contribui para as atividades de reflexão e depuração sejam efetivadas.

\section{CRITÉRIO 2}

\section{Mobilização de diferentes registros de representação no OED}

NÍVEL

3

\section{Justificativa:}

Ao interagir com esse OED o aluno realiza a conversão do registro figural 'especial' (ilustrações das circunferências, ponteiro e do alvo) para o registro numérico (medidas de ângulos e dos comprimentos de arcos de circunferência). A conversão ocorre, pois, o aluno deve observar a posição do ponteiro em relação ao alvo para, depois, estimar a medida do comprimento do arco ou a medida do ângulo.

\section{CRITÉRIO 3}

Interdisciplinaridade e contextualização

\section{NÍVEL \\ 3}

\section{Justificativa:}

O contexto presente nesse OED é significativo (contexto intramatemático) pois estimula os alunos a estabelecerem relações entre diferentes conceitos ou noções próprias da Matemática como a ideia de proporcionalidade e as de medidas de ângulos e de comprimentos de arcos de circunferência.

Quadro 20: Análise do OED Jogo dos arcos de circunferência. 


\subsection{O corpo humano}

O OED O corpo humano é um infográfico animado voltado para os alunos do 6 a ano do Ensino Fundamental e que os coloca em contato com dados quantitativos - medidas de capacidade, comprimento, tempo e superfície - a respeito do funcionamento do corpo humano.

As informações que os alunos podem acessar ao interagir com esse OED versam sobre: a medida da superfície da pele, quantidade de litros de ar inalado a cada inspiração, quantidade de litros de sangue bombeada pelo coração, variação da frequência dos batimentos cardíacos, quantidade de litros de sangue filtrada pelos rins e quantidade de litros de urina produzida, comprimento do tubo digestório e o tempo que uma refeição completa pode levar para percorrê-lo e, o maior e o menor osso, em comprimento, do corpo humano.

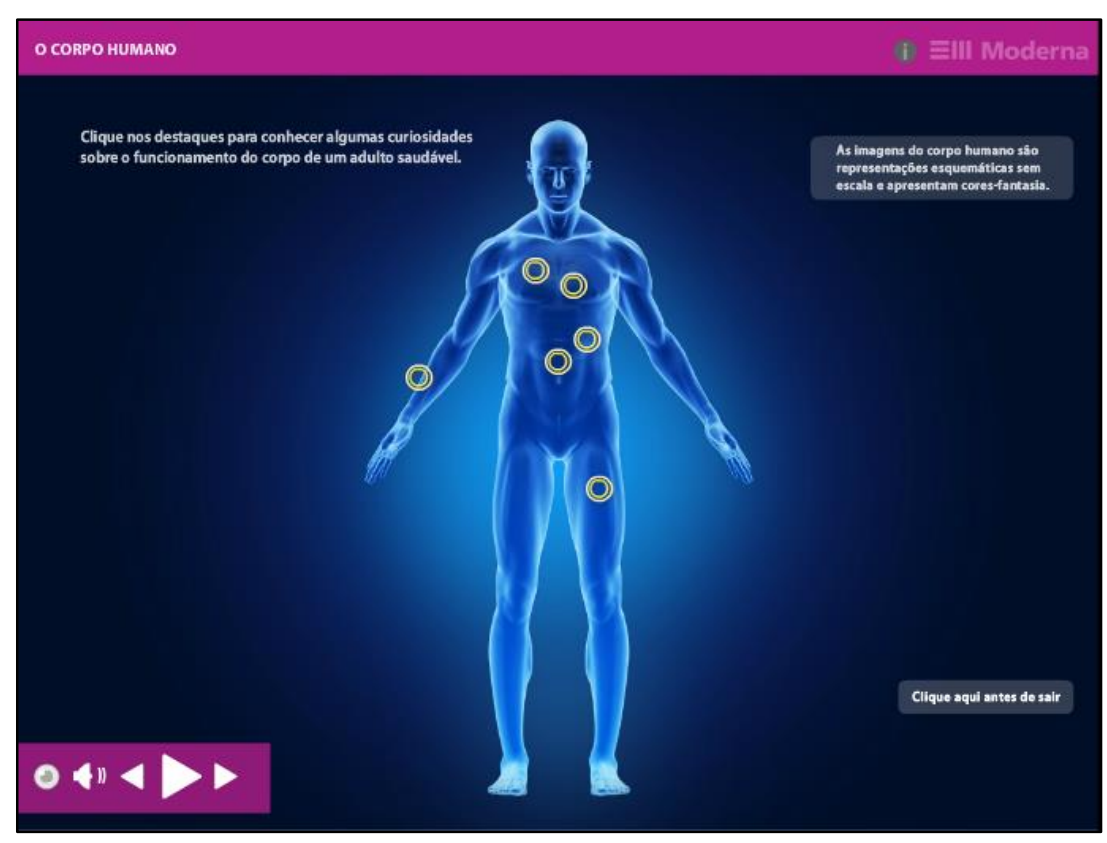

Figura 44: Tela inicial do OED O corpo humano.

Para obter essas informações, o aluno deve clicar nos destaques sobre a representação do corpo humano. Ao clicar, é reproduzida uma animação em que as informações são passadas via áudio, podendo o aluno optar por sua transcrição. Ele também pode interromper a reprodução a qualquer momento. 


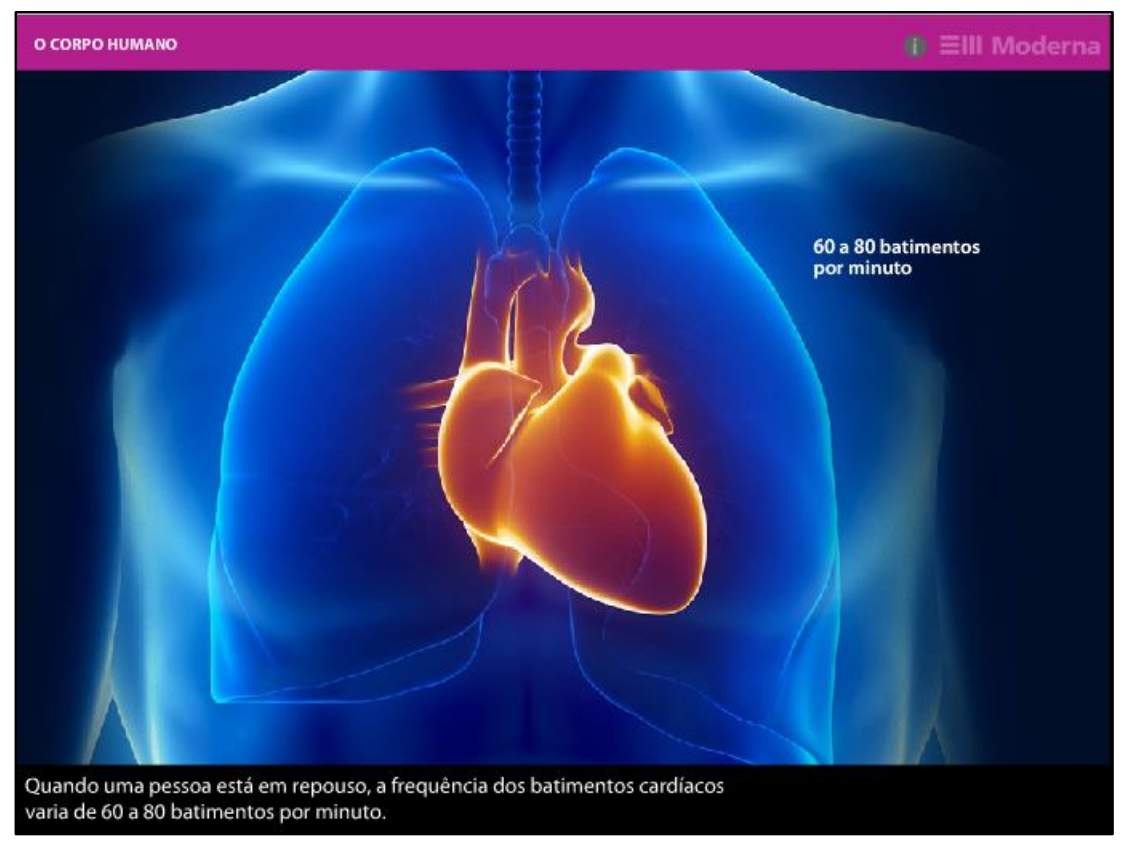

Figura 45: Informações sobre o coração.

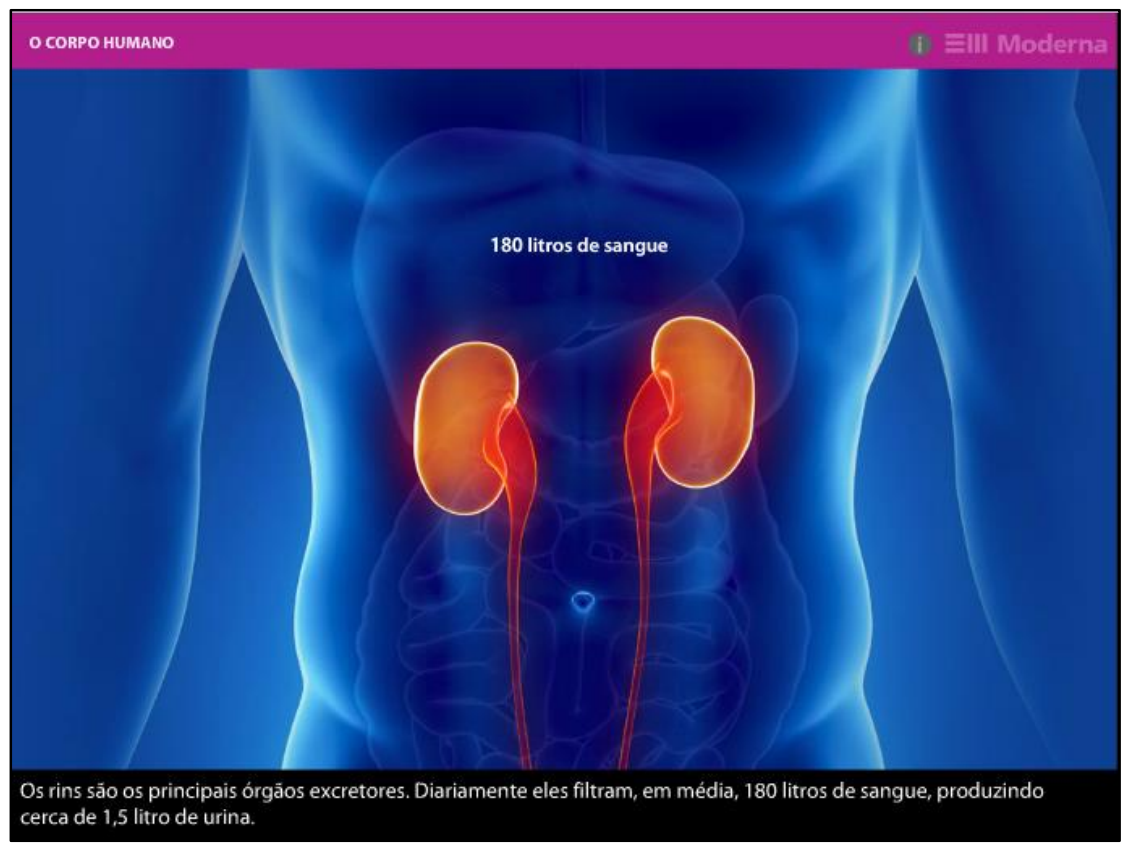

Figura 46: Informações sobre os rins.

Nas orientações ao professor, são propostas questões para os alunos responderem após a interação com esse OED. Tais questões solicitam que eles respondam que unidades de medida - citadas no infográfico - estão associadas às grandezas capacidade, comprimento, tempo e superfície, bem como quais delas são um múltiplo ou submúltiplo de outra unidade. Além disso, pergunta-se sobre a média 
de batimentos do coração no período de uma hora com base na informação de que o coração de uma pessoa em repouso bate de 60 a 80 vezes por minuto.

$\mathrm{Na}$ interação com esse OED o aluno pode interromper a reprodução a qualquer momento, aumentar ou diminuir o volume e ainda optar pela presença de legenda.

\begin{tabular}{|c|c|}
\hline \multicolumn{2}{|l|}{ Análise do OED O corpo humano } \\
\hline CRITÉRIO 1 & \\
\hline \multicolumn{2}{|c|}{$\begin{array}{l}\text { Justificativa: } \\
\text { Ao interagir com o OED, o aluno seleciona com o mouse as reproduções que desejar para, em } \\
\text { seguida, escutar e/ou ler na tela as informações fornecidas. Considera-se que o OED "moderniza" a } \\
\text { prática pautada na exposição do conteúdo. Entretanto, as imagens e os efeitos especiais apenas } \\
\text { enriquecem tal exposição, facilitando a aprendizagem dos alunos. }\end{array}$} \\
\hline $\begin{array}{c}\text { CRITÉRIO } 2 \\
\text { Mobilização de diferentes registros de representação no OED }\end{array}$ & $\begin{array}{l}\text { NÍVEL } \\
2\end{array}$ \\
\hline \multicolumn{2}{|c|}{$\begin{array}{l}\text { Justificativa: } \\
\text { O OED trabalha - sem, no entanto, estabelecer qualquer relação - com dois registros de } \\
\text { representação diferentes: registro da língua natural (por exemplo, narração das medidas de } \\
\text { capacidade) e o registro numérico (números que indicam medidas de capacidade, comprimento, } \\
\text { tempo e superfície). }\end{array}$} \\
\hline $\begin{array}{c}\text { CRITÉRIO } 3 \\
\text { Interdisciplinaridade e contextualização }\end{array}$ & NÍVEL \\
\hline \multicolumn{2}{|c|}{$\begin{array}{l}\text { Justificativa: } \\
\text { É possível, a partir do contexto proposto, desencadear uma proposta interdisciplinar, uma vez que, } \\
\text { o professor pode incentivar seus alunos a realizar um projeto de pesquisa visando responder, por } \\
\text { exemplo, perguntas como as seguintes: } \\
\text { - Como os dados apresentados na animação foram obtidos?; } \\
\text { - Esses dados variam de pessoa para pessoa? Por quê?; } \\
\text { - Existem doenças que podem afetar os números apresentados? Quais? } \\
\text { A resposta a essas perguntas se situa no âmbito das disciplinas Ciências e Matemática. Já a } \\
\text { necessidade de interpretar as informações obtidas e de se expressar ao responder as perguntas, } \\
\text { trazem à tona a importância da Língua Portuguesa para o desenvolvimento do referido projeto. }\end{array}$} \\
\hline
\end{tabular}

Quadro 21: Análise do OED O corpo humano. 


\subsection{0 Área}

O OED Área é um audiovisual de 4 minutos e 28 segundos de duração proposto para alunos do $6^{\circ}$ ano do Ensino Fundamental. Nele é abordada a ideia de que medir uma superfície é comparar com uma unidade de área. É trabalhada também a comparação entre áreas de diferentes polígonos por meio de experimentos usando o geoplano. Além disso, é comentado brevemente o fato de que povos da Antiguidade, como o mesopotâmico e o egípcio, já mediam superfícies e calculavam áreas.

As imagens a seguir exibem algumas cenas desse vídeo:

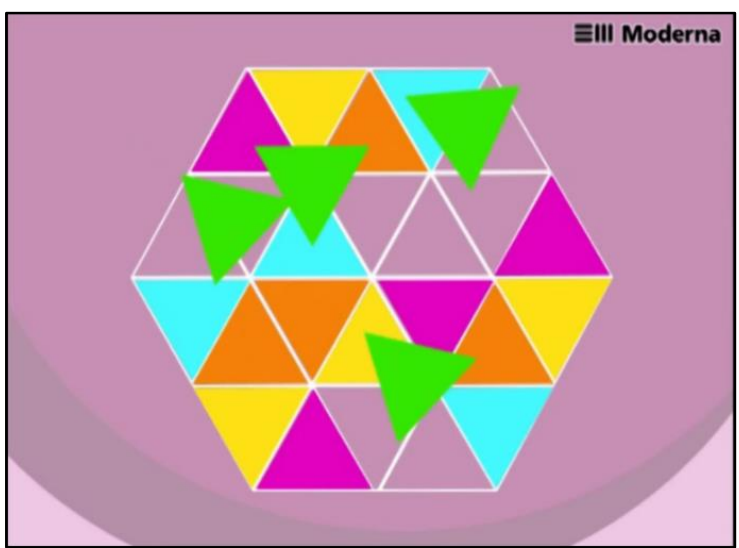

Figura 47: Cena que mostra um hexágono decomposto em triângulos congruentes.

Adotando a área de cada triângulo como unidade de área é possível medir a superfície desse hexágono.

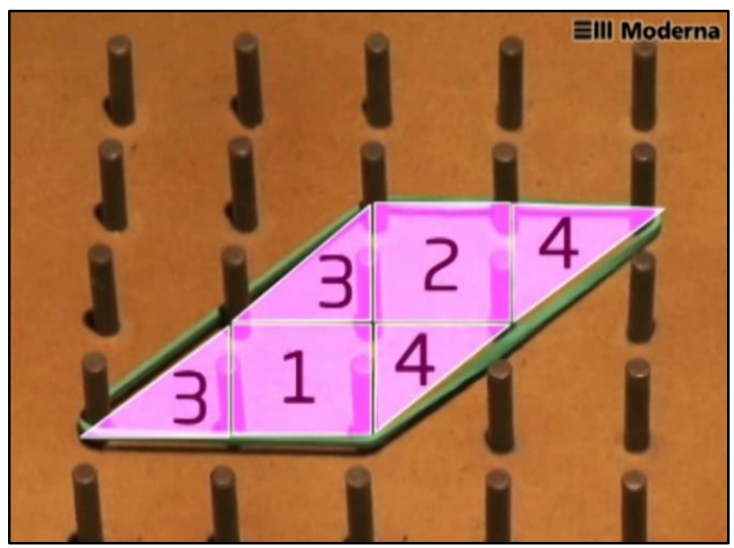

Figura 49: Cena que mostra como determinar a área da superfície de um paralelogramo adotando os quadrinhos do geoplano como unidades de área.

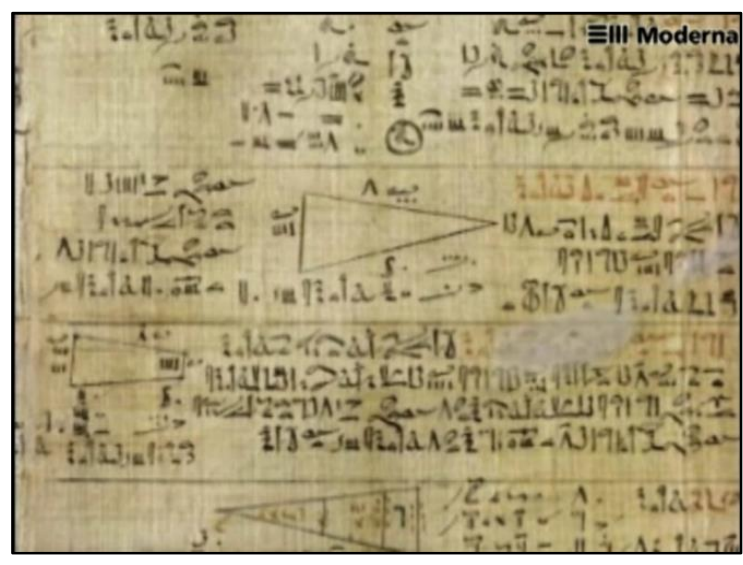

Figura 48: Cena que mostra detalhe do papiro Rhind em que constam alguns problemas envolvendo cálculo de áreas de figuras geométricas.

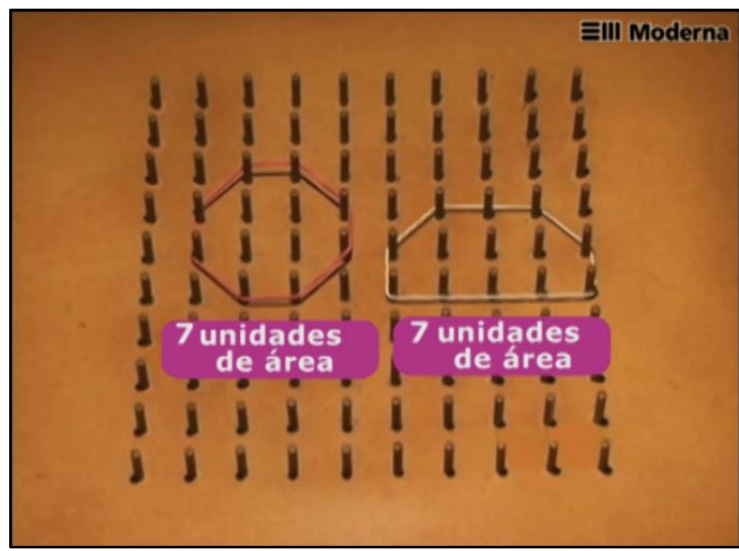

Figura 50: Cena que mostra que polígonos diferentes podem ter a mesma área. 
Durante a exibição do vídeo o aluno pode interrompê-lo a qualquer momento, aumentar ou diminuir o volume, escolher entre a exibição em tela cheia ou reduzida, optar por vê-lo em High Definition (HD) e ainda, alterar o brilho da imagem.

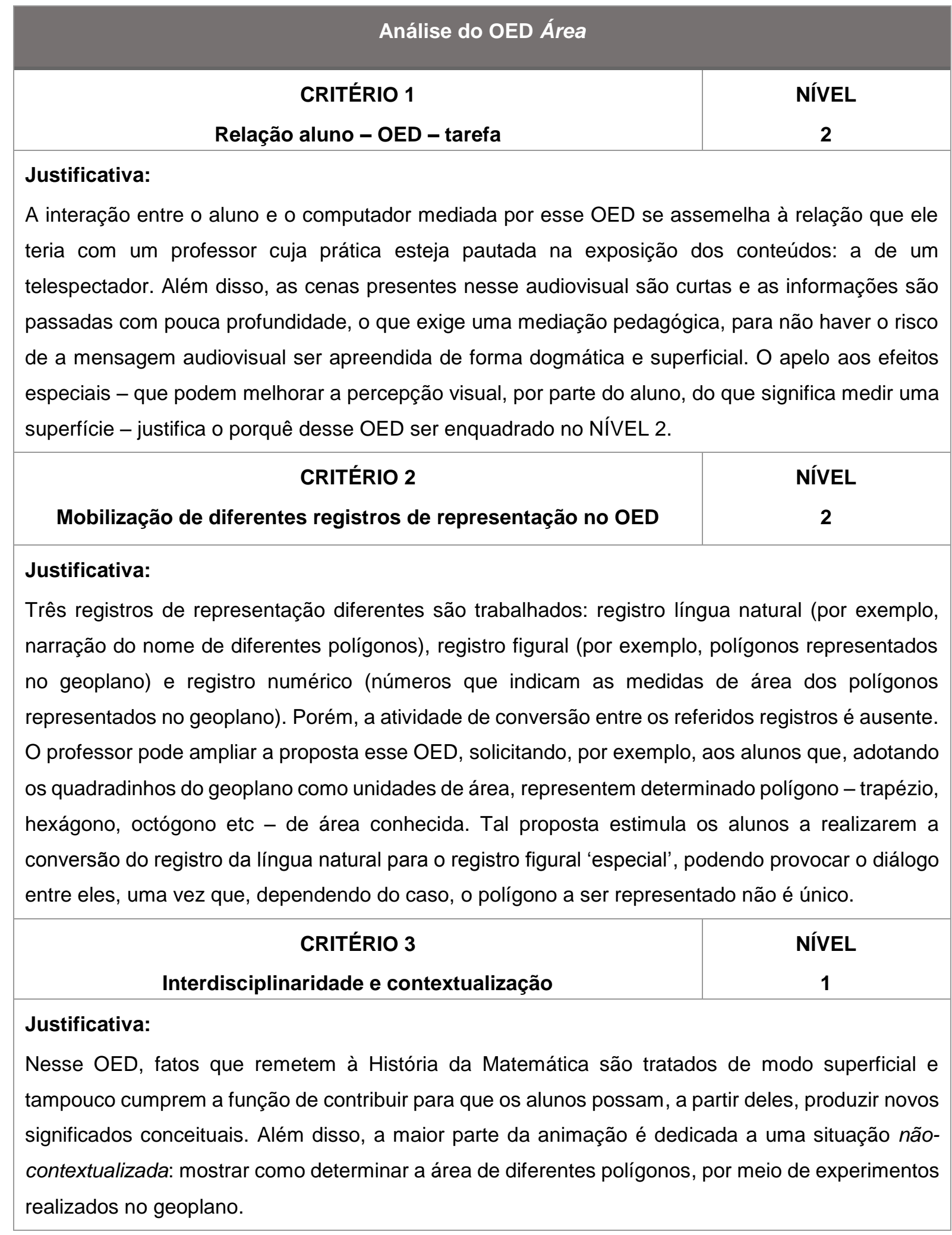

Quadro 22: Análise do OED Área. 


\subsection{Equipamentos de mergulho}

O OED Equipamentos de mergulho é um misto de audiovisual e infográfico animado voltado para os alunos do $7^{\circ}$ ano do Ensino Fundamental. O objetivo do referido objeto é apresentar as primeiras ideias de números positivos e negativos, relacionando o aperfeiçoamento das roupas de mergulho com profundidades cada vez mais profundos que o homem conseguiu alcançar nos oceanos.

O primeiro contato do aluno com esse OED é por meio de um audiovisual em que é abordada a necessidade do homem de criar equipamentos de mergulho, seja para o lazer, seja para uso profissional. Segundo o vídeo, o aperfeiçoamento de tais equipamentos visa evitar a perda de calor do corpo e também proteger o mergulhador de cortes acidentais em rochas, além de queimaduras ou ferimentos provocados por animais venenosos. As imagens a seguir exibem algumas cenas desse audiovisual:

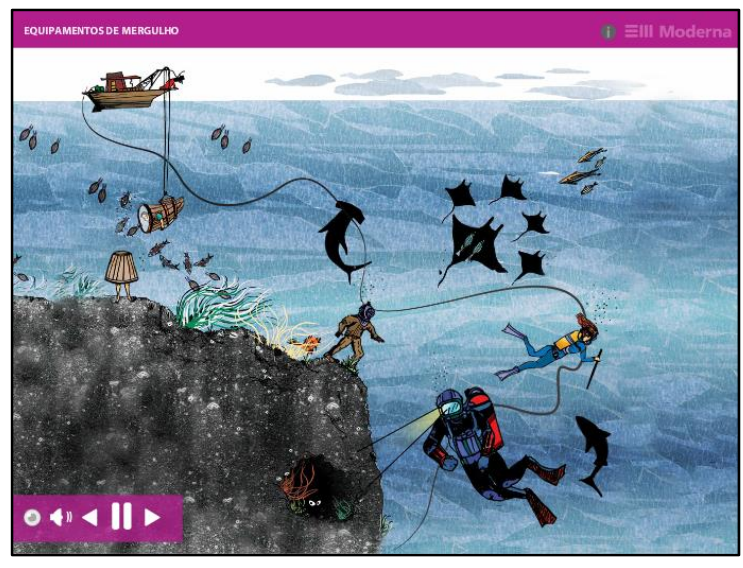

Figura 51: Cena que mostra o aperfeiçoamento das roupas de mergulho.

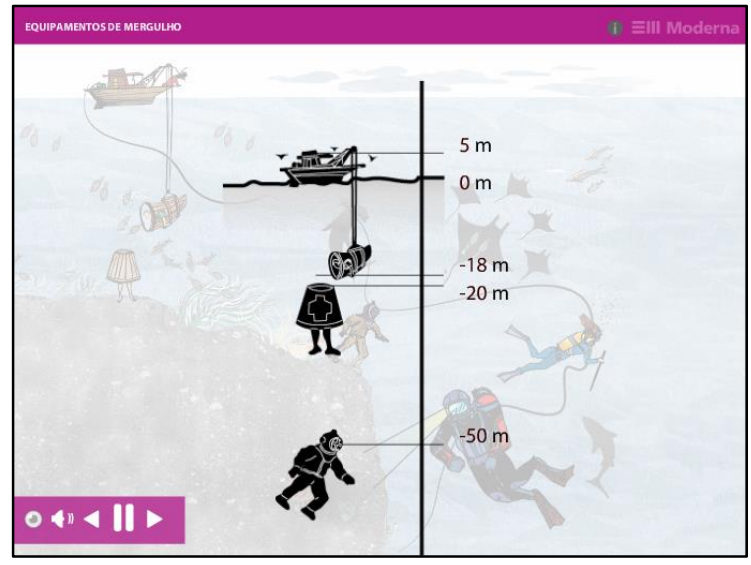

Figura 52: Cena que mostra as profundidades de mares e oceanos já alcançadas pelo homem, em virtude da evolução das roupas de mergulho.

Após a exibição do audiovisual, os alunos passam a interagir com um infográfico animado que os coloca em contato com informações especificas obre as roupas de mergulho desenvolvidas ao longo dos anos, relacionando-as com as profundidades que o homem pôde alcançar com elas. 


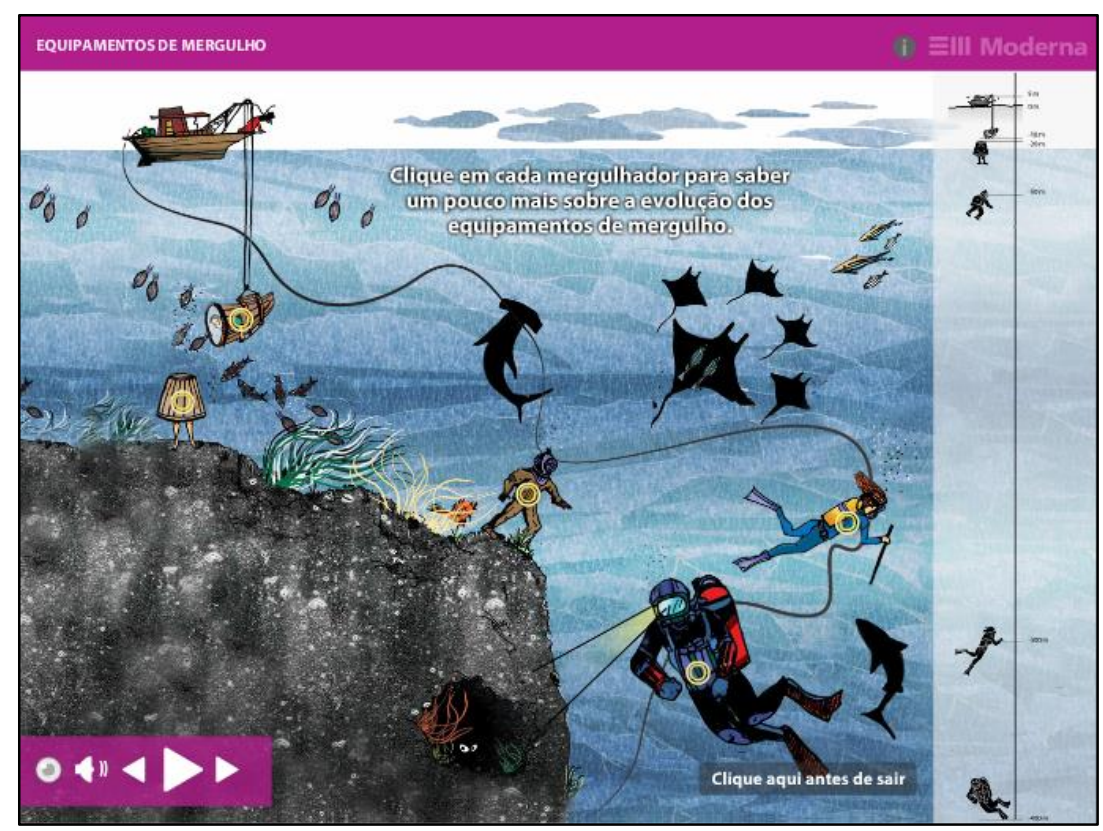

Figura 53: Tela inicial do infográfico animado presente no OED Equipamentos de mergulho.

Para ter acesso às informações referidas, o aluno deve clicar nos mergulhadores. A partir daí, é reproduzida uma animação em que as informações são passadas via áudio, podendo o aluno optar por sua transcrição. Ele também pode interromper a reprodução a qualquer momento.

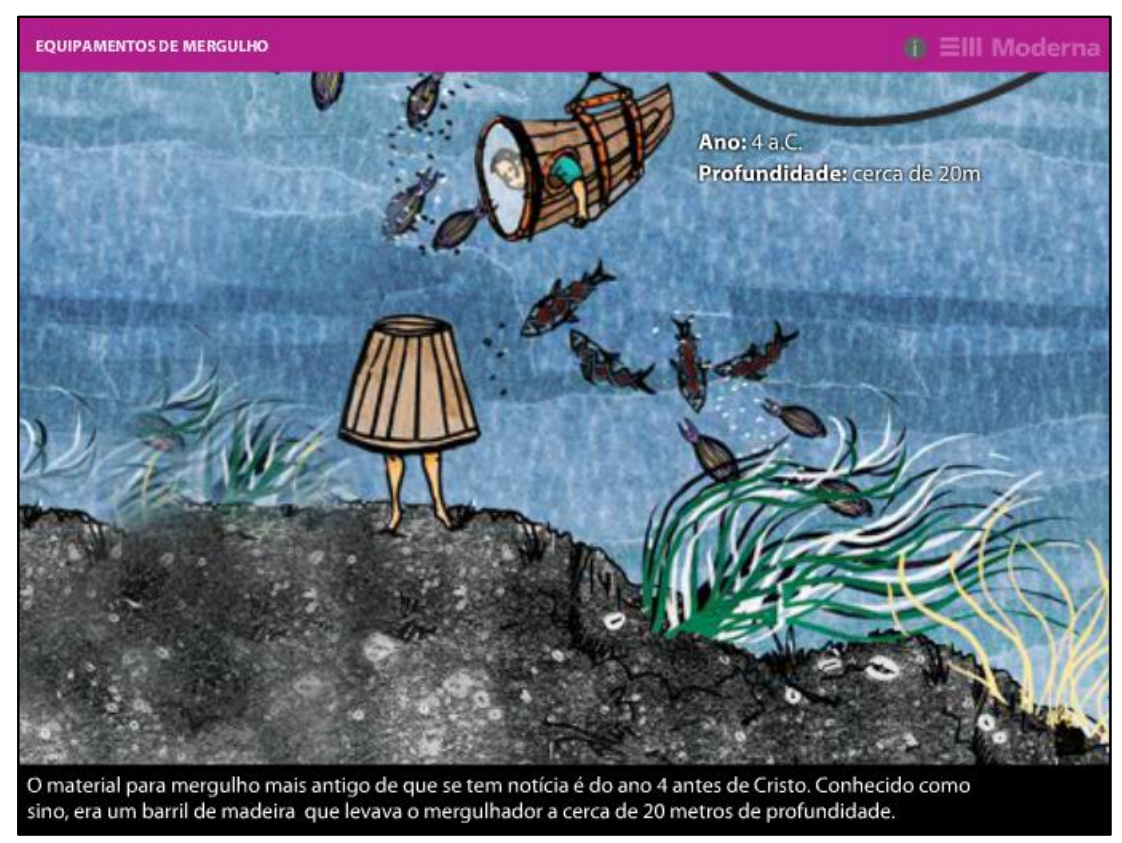

Figura 54: Informações sobre o material de mergulho mais antigo. 


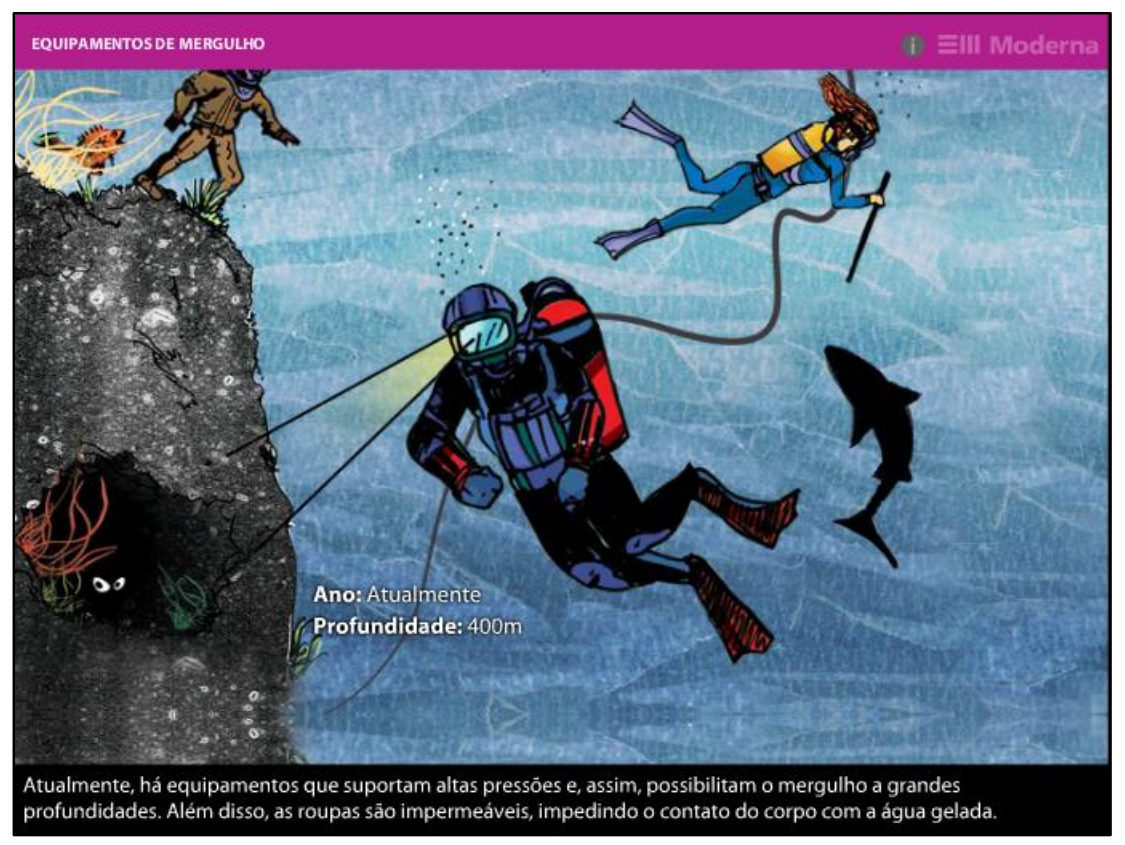

Figura 55: Informações sobre o material de mergulho usado atualmente.

\begin{tabular}{|c|c|}
\hline \multicolumn{2}{|l|}{ Análise do OED Equipamentos de mergulho } \\
\hline & \\
\hline \multicolumn{2}{|c|}{$\begin{array}{l}\text { Justificativa: } \\
\text { Na interação com esse OED o aluno não é induzido a investigar e nem tampouco a estabelecer } \\
\text { conjecturas. Isso se deve ao fato de que, após assumir o papel de mero telespectador, ele apenas } \\
\text { precisa selecionar com o mouse as reproduções que desejar, para, em seguida, escutar ou ler na } \\
\text { tela as informações fornecidas. Assim, esse OED substitui uma aula pautada na exposição dos } \\
\text { conteúdos, agregando, porém, as imagens e os efeitos especiais que enriquecem tal exposição. }\end{array}$} \\
\hline $\begin{array}{c}\text { CRITÉRIO } 2 \\
\text { Mobilização de diferentes registros de representação no OED }\end{array}$ & \\
\hline \multicolumn{2}{|c|}{$\begin{array}{l}\text { Justificativa: } \\
\text { O OED lida, com três registros de representação diferentes, sem, no entanto, estimular a conversão } \\
\text { entre eles: registro na língua natural (narração das medidas de profundidade), registro gráfico (reta } \\
\text { numerada mostrando a localização de alguns números inteiros) e registro numérico (números que } \\
\text { indicam as medidas de profundidade alcançadas pelo homem conforme o equipamento de mergulho } \\
\text { utilizado). A fim de enriquecer a proposta desse OED, o professor pode - por meio da ideia de } \\
\text { comparação da subtração - estimular os alunos a compararem as medidas de profundidade } \\
\text { alcançadas pelo homem. Isso não só possibilitaria a realização do tratamento no registro numérico } \\
\text { como também poderia contribuir para a atribuição de significado à operação. }\end{array}$} \\
\hline
\end{tabular}




\begin{tabular}{|l|c|}
\hline \multicolumn{1}{|c|}{ CRITÉRIO 3 } & \multicolumn{1}{|c|}{ NíVEL } \\
\hline Justerdisciplinaridade e contextualização & 3 \\
A relação entre a história do desenvolvimento e aperfeiçoamento dos equipamentos de mergulho \\
com a profundidade de mares e oceanos que o homem passou a alcançar é um contexto com \\
potencial de contribuir para que o aluno atribua significado aos números inteiros, sobretudo aos \\
negativos. O contexto apresentado permite ao aluno perceber que o fato de um número ser positivo \\
ou negativo depende de um referencial: o nível do mar é tomado como referência e assume-se que \\
acima dele, as medidas são positivas, enquanto que abaixo, as medidas são consideradas negativas. \\
Em virtude disso, considera-se que o contexto proposto é significativo.
\end{tabular}

Quadro 23: Análise do OED Equipamentos de mergulho.

\subsection{Cálculo algébrico}

O OED Cálculo algébrico é um audiovisual de 8 minutos e 22 segundos de duração, destinado aos alunos do $8^{\circ}$ ano do Ensino Fundamental. Nele é introduzido o cálculo algébrico por meio do cálculo da área de polígonos regulares e irregulares numa malha pontilhada. Esse elo desejado entre geometria e álgebra se dá com base na Fórmula de Pick, que possibilita determinar a área de polígonos no plano cartesiano desde que seus vértices coincidam com pontos cujas coordenadas sejam números inteiros.

As imagens a seguir exibem algumas cenas desse audiovisual:

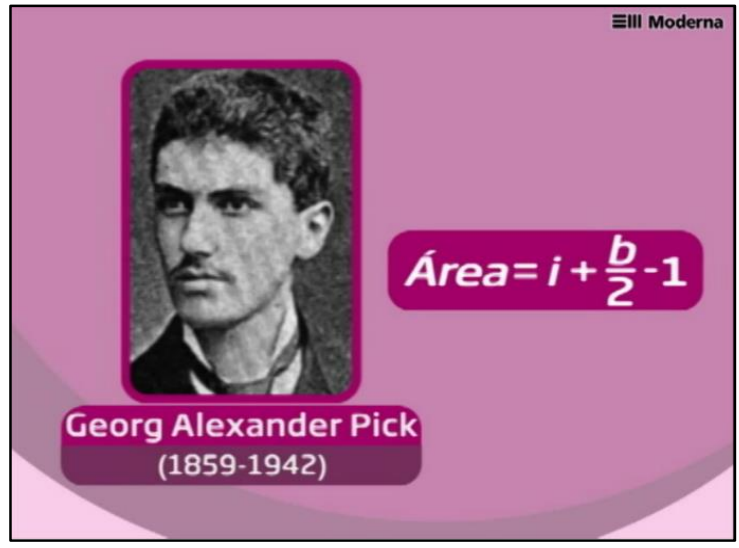

Figura 56: Cena em que é apresentada a fórmula de Pick.

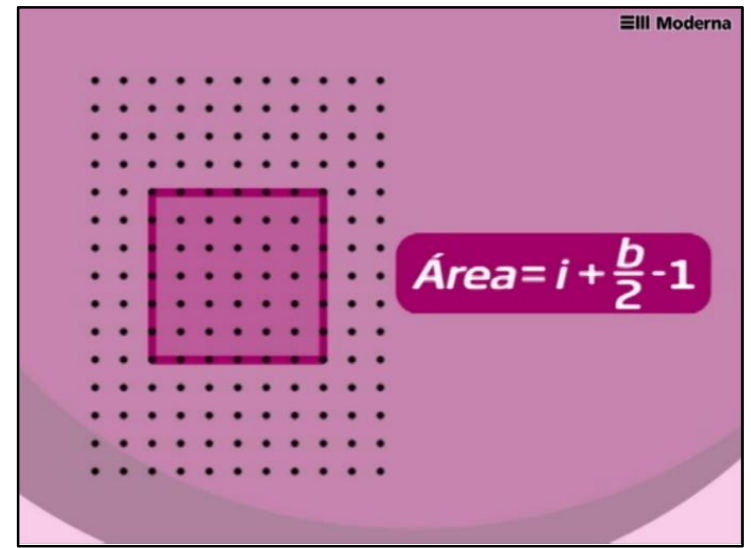

Figura 57: Cena que apresenta o significado das variáveis presentes na Fórmula de Pick. 


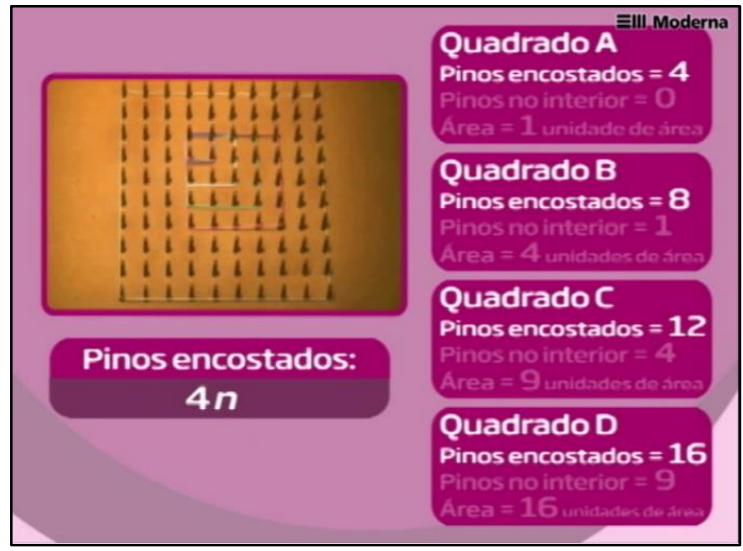

Figura 58: Cena que mostra como a álgebra pode ser utilizada para descrever um padrão que facilita a determinação da quantidade de pinos encostados, isto é, no contorno de um

quadrado representado no geoplano.

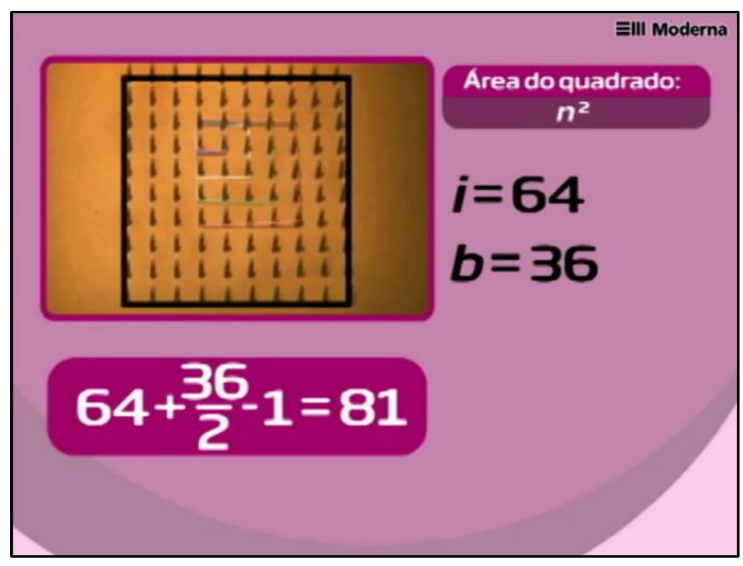

Figura 60: Cena que mostra a aplicação da fórmula de Pick para determinar a área de um quadrado de lado 9.

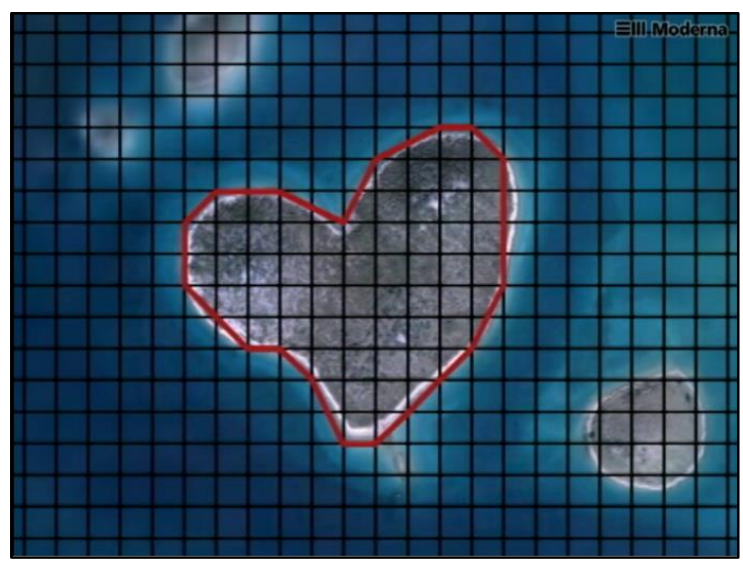

Figura 62: Cena que inicia a demonstração de como determinar a área aproximada da ilha de Galesnjak na Croácia.

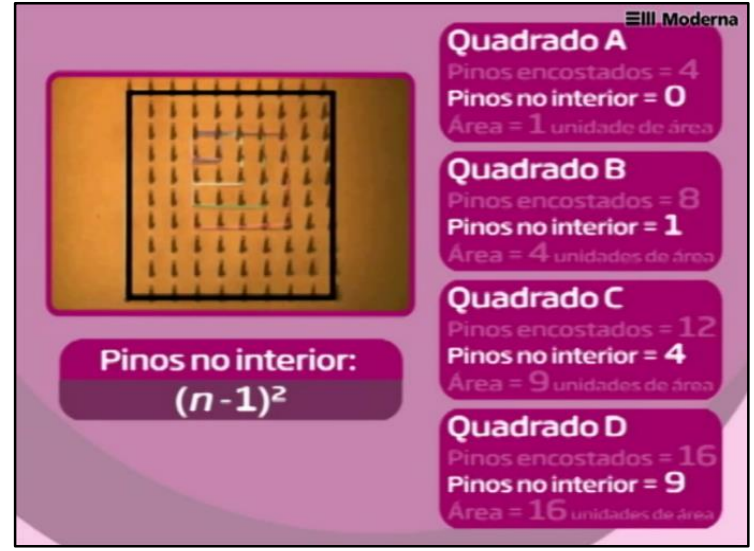

Figura 59: Cena que mostra como a álgebra pode ser utilizada para descrever um padrão que facilita a determinação da quantidade de pinos no interior de um quadrado representado no geoplano.

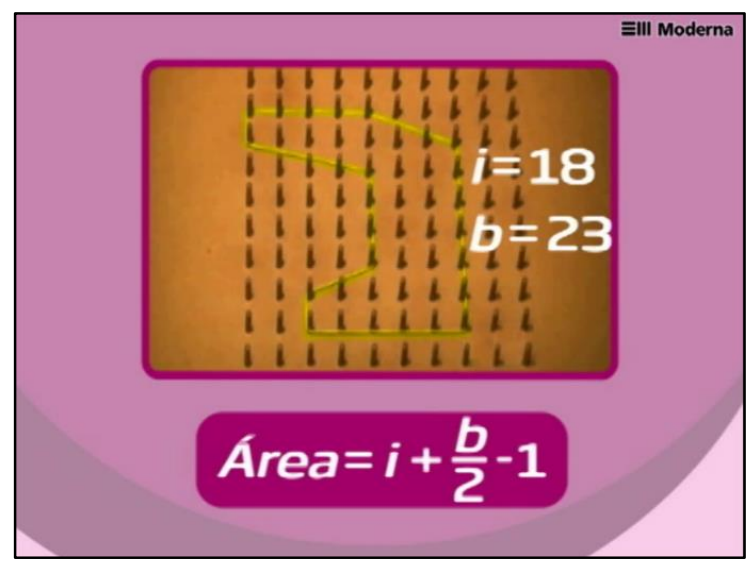

Figura 61: Cena que mostra a aplicação da fórmula de Pick para determinar a área de um polígono irregular.

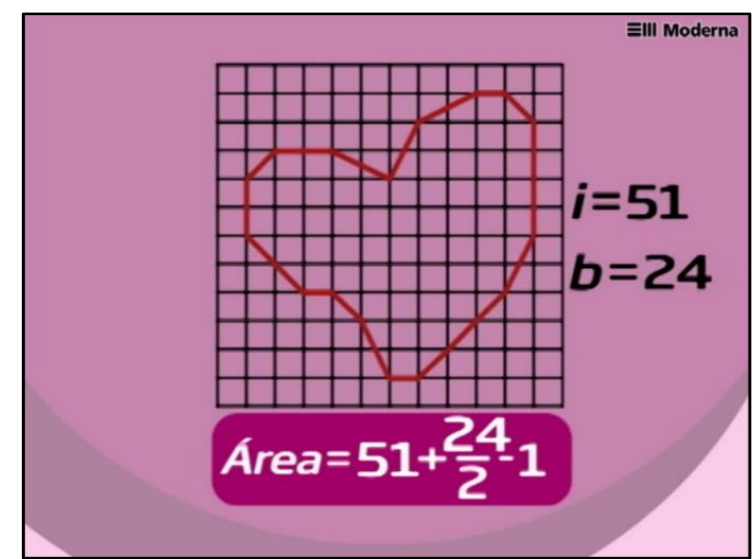

Figura 63: Cena que mostra que aplicando a fórmula de Pick conclui-se que a área aproximada da ilha de Galesnjak na Croácia é de 62 unidades de área. 
Durante a exibição do vídeo o aluno pode interrompê-lo a qualquer momento, aumentar ou diminuir o volume, escolher entre a exibição em tela cheia ou reduzida, optar por vê-lo em High Definition (HD) e ainda, alterar o brilho da imagem.

\begin{tabular}{|c|c|}
\hline \multicolumn{2}{|l|}{ Análise do OED Cálculo algébrico } \\
\hline $\begin{array}{c}\text { CRITÉRIO } 1 \\
\text { Relação aluno - OED - tarefa }\end{array}$ & \\
\hline \multicolumn{2}{|c|}{$\begin{array}{l}\text { Justificativa: } \\
\text { A postura assumida pelo aluno ao utilizar esse OED é a de um telespectador. Além disso, um } \\
\text { professor que tenha à sua disposição um geoplano e alguns elásticos também pode expor aos alunos } \\
\text { como se pode determinar a área de polígonos regulares ou irregulares por meio da fórmula de Pick. } \\
\text { Em virtude disso, considera-se que o uso desse OED oferece apenas o benefício prático de que o } \\
\text { professor não necessita ter tais materiais para a condução da aula. }\end{array}$} \\
\hline $\begin{array}{c}\text { CRITÉRIO } 2 \\
\text { Mobilização de diferentes registros de representação no OED }\end{array}$ & \\
\hline \multicolumn{2}{|c|}{$\begin{array}{l}\text { Justificativa: } \\
\text { Predomina nesse OED o trabalho com o registro algébrico (fórmula de Pick e expressões que } \\
\text { representam as quantidades de pinos no contorno e no interior de quadrados representados no } \\
\text { geoplano em função da medida do lado) mas também se trabalha o registro figural (polígonos } \\
\text { representados no geoplano e em malhas pontilhadas). A efetivação da proposta desse OED passa } \\
\text { necessariamente pelo recurso aos registros mencionados, porém a conversão entre eles é uma } \\
\text { atividade ausente durante toda a exibição desse audiovisual. }\end{array}$} \\
\hline & \\
\hline \multicolumn{2}{|c|}{$\begin{array}{l}\text { Justificativa: } \\
\text { O OED em questão recorre a um contexto intradisciplinar para introduzir o cálculo algébrico, uma } \\
\text { vez que, sua proposta é desencadeada a partir da observação do Teorema de Pick e da } \\
\text { generalização de padrões. Entende-se que tais circunstâncias permitem ao aluno atribuir significado } \\
\text { a esse tipo de cálculo, uma vez que pode perceber o significado das letras (variáveis) em uma } \\
\text { expressão algébrica e também compreender que tais expressões, muitas vezes, são generalizações } \\
\text { de relações entre números. Além disso, é mostrada como a referida fórmula pode ser aplicada para } \\
\text { a determinação da área aproximada de uma ilha. Desta forma, os contextos, com os quais lida esse } \\
\text { OED, são significativos. }\end{array}$} \\
\hline
\end{tabular}

Quadro 24: Análise do OED Cálculo algébrico. 


\subsection{Localizando terremotos}

O OED Localizando terremotos é um audiovisual de 2 minutos e 58 segundos de duração, destinado aos alunos do 8ำ ano do Ensino Fundamental. Nele é exibido como o conceito de intersecção entre circunferências secantes é aplicado para localizar o epicentro ${ }^{50}$ de um terremoto. $O$ conceito de terremoto, os tipos principais de ondas propagadas e seus efeitos e o funcionamento do sismógrafo são temas também abordados por esse OED.

O sismógrafo é o instrumento que detecta as ondas tipo $\mathrm{P}$ (primárias) e tipo $\mathrm{S}$ (secundárias): as primeiras se propagam a uma velocidade de, aproximadamente, 5 $\mathrm{km} / \mathrm{s}$ e provocam a compressão e expansão das rochas, enquanto que as últimas se propagam pela crosta terrestre, movendo-se para cima e para baixo, a uma velocidade próxima de $3 \mathrm{~km} / \mathrm{s}$ e são as responsáveis pelos danos materiais. A distância entre o sismógrafo e o epicentro do terremoto é determinada por meio da diferença de tempo entre a chegada dessas ondas $\mathrm{P}$ e $\mathrm{S}$ no instrumento. É possível com um sismógrafo determinar também a duração e a intensidade dos terremotos.

As imagens a seguir exibem algumas cenas desse audiovisual:

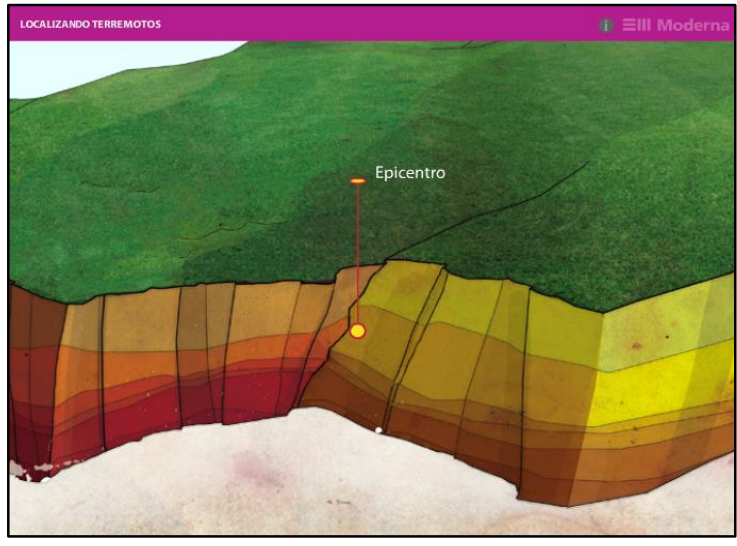

Figura 64: Cena em que é apresentado o que é o epicentro de um terremoto.

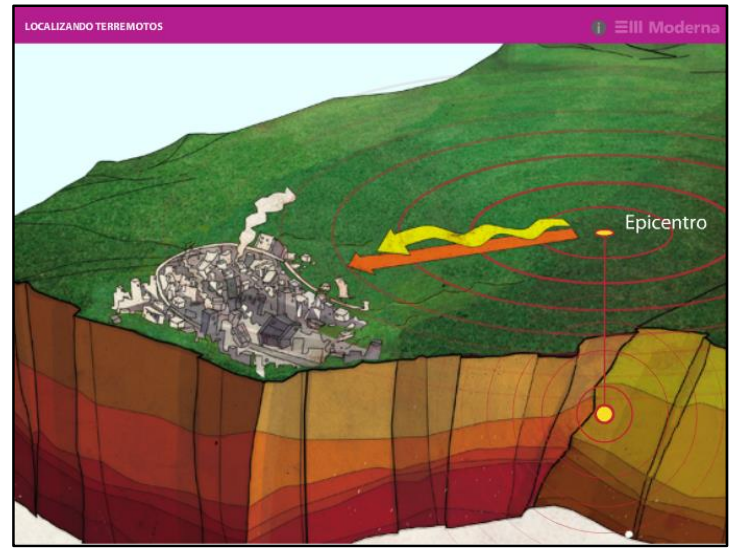

Figura 65: Cena em que se comenta sobre as ondas P (laranja) e as ondas S (amarelo).

50 Epicentro é o ponto da superfície da terra localizado logo acima do ponto em que se originou o terremoto. 


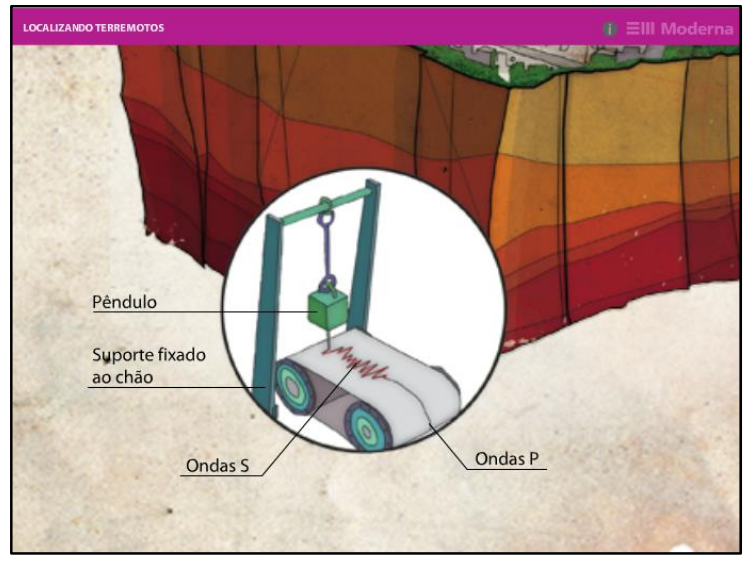

Figura 66: Cena em que se explica o funcionamento de um sismógrafo.

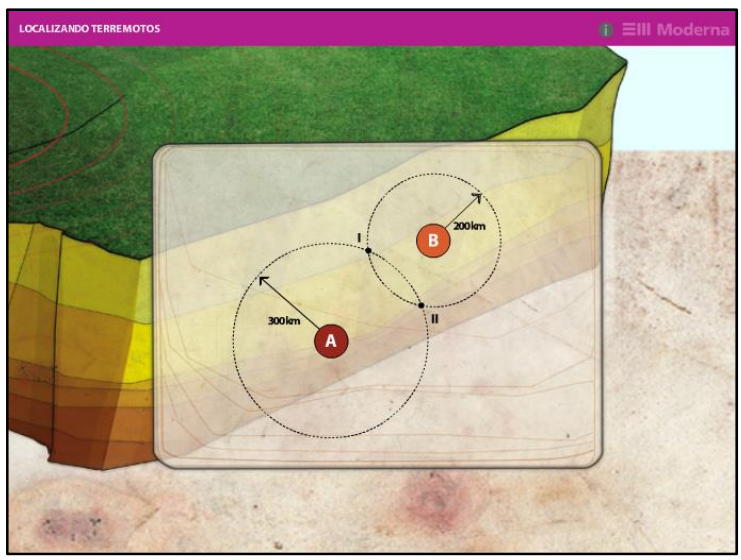

Figura 68: Cena que mostra que com dois sismógrafos conclui-se que o epicentro do terremoto está no ponto indicado por I ou por II.

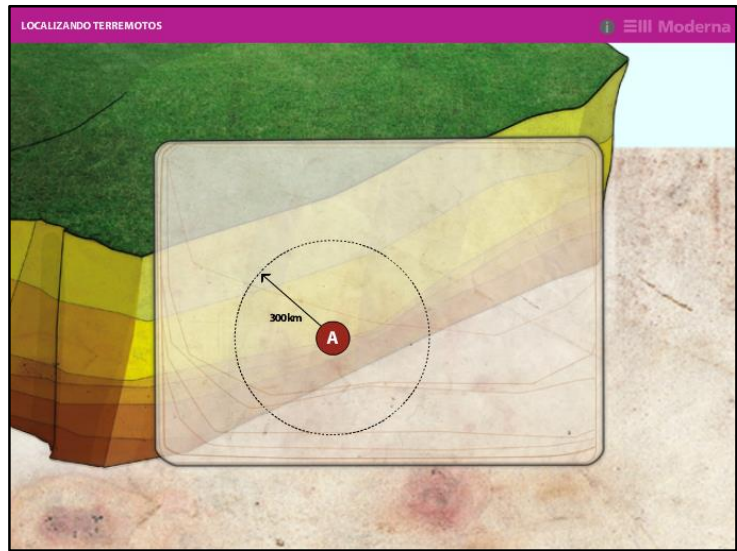

Figura 67: Cena que mostra que com apenas um sismógrafo, conclui-se que o epicentro do terremoto está na circunferência centrada em

A e com raio $300 \mathrm{~km}$.

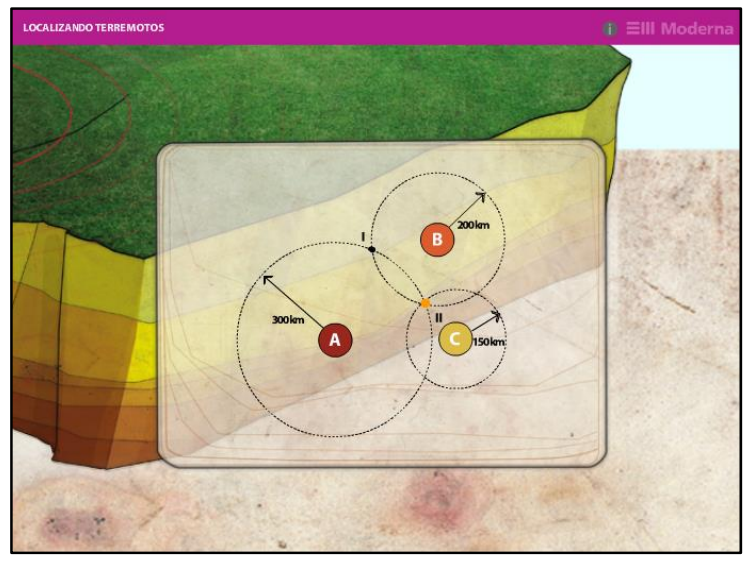

Figura 69: Cena que mostra que a posição exata do epicentro só é determinada com o auxílio de um terceiro sismógrafo.

Nas orientações ao professor para o uso do objeto, são sugeridas três atividades a serem propostas aos alunos após a interação com o OED. A atividade 1, estimula-os a refletir sobre a possibilidade de determinar a localização exata do epicentro de um abalo utilizando-se apenas 2 sismógrafos ${ }^{51}$. Já as atividades 2 e 3 , propõem situações problema, inspiradas no contexto da localização de terremotos, nas quais os alunos precisam manipular expressões algébricas para responder às questões propostas.

${ }^{51}$ É possível que por meio dessa atividade os alunos percebam que somente nos casos em que as circunferências com centro em cada um dos sismógrafos são tangentes, seria possível determinar a posição exta do epicentro sem necessitar de um terceiro sismógrafo. 


\begin{tabular}{|c|c|}
\hline & \\
\hline \multicolumn{2}{|c|}{$\begin{array}{l}\text { Justificativa: } \\
\text { O que está por trás da proposta desse OED é a prática pautada na exposição do conteúdo seguida } \\
\text { de atividades que o professor pode ou não propor aos alunos, uma vez que elas constam somente } \\
\text { nas orientações ao professor. Assim, o OED em questão não contribui para que o aluno possa } \\
\text { produzir conhecimento, visto que, na interação com esse audiovisual, ele apenas escuta e visualiza } \\
\text { as informações e as imagens na tela. No entanto, os efeitos especiais e as imagens presentes podem } \\
\text { enriquecer a exposição do professor. }\end{array}$} \\
\hline & \\
\hline \multicolumn{2}{|c|}{$\begin{array}{l}\text { Justificativa: } \\
\text { Além do registro na língua natural, o OED também trabalha, mas de modo independente, com o } \\
\text { registro figural (circunferências cujos centros coincidem com a posição dos sismógrafos e com raio } \\
\text { que corresponde à distância entre o sismógrafo e o epicentro do terremoto). As atividades presentes } \\
\text { nas orientações ao professor enriquecem o trabalho com esse audiovisual e possibilitam o trabalho } \\
\text { com tratamentos no registro algébrico e, também, a recorrer ao registro figural para interpretar as } \\
\text { situações descritas nos enunciados. }\end{array}$} \\
\hline & \\
\hline \multicolumn{2}{|c|}{$\begin{array}{l}\text { Justificativa: } \\
\text { O contexto presente nesse OED mostra uma aplicação prática do estudo da posição relativa entre } \\
\text { duas circunferências. Situações envolvendo terremotos estão presentes no cotidiano dos alunos, } \\
\text { uma vez que notícias sobre sua ocorrência, em determinadas regiões do mundo, são veiculadas } \\
\text { pelos meios de comunicação. Além disso, tal circunstância contribui para que eles atribuam } \\
\text { significado ao estudo da posição relativa entre duas circunferências. Logo, o contexto no qual o } \\
\text { audiovisual se desenrola é significativo e pode contribuir para que seja desencadeada um projeto } \\
\text { interdisciplinar com Geografia e Ciências, visando responder as seguintes questões: } \\
\text { - Por que os terremotos acontecem? } \\
\text { - Quais regiões do mundo são mais propicias a terremotos? Por quê? } \\
\text { - Como alguns países convivem com o problema dos terremotos? }\end{array}$} \\
\hline
\end{tabular}

Quadro 25: Análise do OED Localizando terremotos. 


\section{Considerações Finais}

A presença de OED nos livros didáticos de Matemática é recente e talvez seja esse o motivo de haver poucas pesquisas na área de Educação cujo foco esteja especificamente nesses recursos.

Compreender de que forma esses objetos podem contribuir para o processo de ensino e aprendizagem de Matemática foi o desafio que nos propusemos e que se traduziu na seguinte questão: quais são as possíveis contribuições dos OED para a construção do conhecimento em Matemática?

A busca por respostas a essa pergunta iniciou-se com o estabelecimento de um referencial teórico constituído por autores que propõem teorias e desenvolveram pesquisas visando a construção do conhecimento, particularmente em Matemática. Assim, com o respaldo em tal referencial, estabelecemos os seguintes critérios para examinar cada um dos referidos OED:

- Relação aluno - OED - tarefa;

- Mobilização de diferentes registros de representação;

- Interdisciplinaridade e contextualização.

Entendemos que a incorporação dos OED no processo de ensino e aprendizagem de Matemática está além do fato de satisfazer a necessidade de trazer a informática para a sala de aula ou de "modernizar" as coleções de livros didáticos. Qualquer OED é proposto visando contribuir para que os alunos vivenciem experiências nas quais possam desenvolver a própria autonomia e atribuir significado aos conceitos matemáticos.

Nesse sentido, os critérios de análise foram estabelecidos e cada um dos objetos foi examinado. $O$ resultado de tais análises - que foram realizadas no Capítulo 5 - pode ser visualizado no quadro que segue: 


\begin{tabular}{|c|c|c|c|c|c|c|c|c|c|c|c|c|}
\hline \multicolumn{13}{|c|}{ ANÁLISE DOS OED SEGUNDO OS CRITÉRIOS ESTABELECIDOS } \\
\hline \multirow[t]{2}{*}{ OED } & \multicolumn{4}{|c|}{$\begin{array}{c}\text { RELAÇÃO ALUNO - OED - } \\
\text { TAREFA }\end{array}$} & \multicolumn{4}{|c|}{$\begin{array}{c}\text { MOBILIZAÇÃO DE } \\
\text { DIFERENTES REGISTROS } \\
\text { DE REPRESENTAÇÃO }\end{array}$} & \multicolumn{4}{|c|}{$\begin{array}{l}\text { INTERDISCIPLINARIDADE } \\
\text { E CONTEXTUALIZAÇÃO }\end{array}$} \\
\hline & 1 & 2 & 3 & 4 & 1 & 2 & 3 & 4 & 1 & 2 & 3 & 4 \\
\hline $\begin{array}{l}\text { Negócios do } \\
\text { oriente }\end{array}$ & & $\mathrm{x}$ & & & & & $\mathrm{X}$ & & & & $\mathrm{x}$ & \\
\hline $\begin{array}{l}\text { Números do } \\
\text { Brasil }\end{array}$ & & $x$ & & & & $x$ & & & & & & $\mathrm{X}$ \\
\hline Quadriláteros & & & & $\mathrm{x}$ & & & $\mathrm{x}$ & & & & & $\mathrm{X}$ \\
\hline $\begin{array}{l}\text { Analisando } \\
\text { medidas }\end{array}$ & & & $\mathrm{X}$ & & & $\mathrm{X}$ & & & & & $\mathrm{x}$ & \\
\hline Sorteando bolas & & & $\mathrm{x}$ & & & $\mathrm{x}$ & & & & & $\mathrm{x}$ & \\
\hline $\begin{array}{l}\text { Jogos dos } \\
\text { aquários }\end{array}$ & & & & $x$ & & $x$ & & & & $\mathrm{x}$ & & \\
\hline $\begin{array}{l}\text { Juros simples e } \\
\text { composto }\end{array}$ & & & $\mathrm{x}$ & & & $\mathrm{x}$ & & & & & & $\mathrm{X}$ \\
\hline $\begin{array}{l}\text { Jogo dos arcos } \\
\text { de circunferência }\end{array}$ & & & & $x$ & & & $\mathrm{x}$ & & & & $x$ & \\
\hline O corpo humano & & $\mathrm{X}$ & & & & $x$ & & & & & & $\mathrm{X}$ \\
\hline Área & & $x$ & & & & $x$ & & & $x$ & & & \\
\hline $\begin{array}{l}\text { Equipamentos } \\
\text { de mergulho }\end{array}$ & & $\mathrm{X}$ & & & & $x$ & & & & & $x$ & \\
\hline $\begin{array}{l}\text { Cálculo } \\
\text { algébrico }\end{array}$ & & $\mathrm{x}$ & & & & $\mathrm{X}$ & & & & & $\mathrm{X}$ & \\
\hline $\begin{array}{l}\text { Localizando } \\
\text { terremotos }\end{array}$ & & $x$ & & & & $x$ & & & & & & $\mathrm{X}$ \\
\hline
\end{tabular}

Quadro 26: Resultado da análise dos OED segundo os critérios estabelecidos.

No que diz respeito, à relação aluno - OED - tarefa, podemos observar que 6 dos 13 OED analisados favorecem a participação ativa dos alunos frente ao computador, uma vez que os estimulam a investigar, estabelecer conjecturas e a percorrer as etapas do ciclo descrição - execução - reflexão - depuração proposto 
por Valente (1999). Em contrapartida, os outros 7 pouco contribuem para evitar que o trabalho com a Matemática fique restrito à transmissão de informações sobre o saber acumulado nesse campo pois, ou suprem a falta de algum material concreto por exemplo, o soroban - ou, no máximo, tornam mais dinâmica a exposição dos conteúdos - por exemplo, os audiovisuais.

No tocante à mobilização dos diferentes registros de representação, notamos que, em grande parte dos OED analisados, estão presentes dois ou mais registros diferentes, porém os objetos não levam os alunos, sem a intervenção do professor, a realizar atividades de tratamento - aquelas que ocorrem no interior de um mesmo registro - ou de conversão - quando há trânsito entre registros diferentes. Como a condição necessária para a construção do conhecimento repousa, segundo a teoria dos registros de representação semiótica proposta por Duval, sobre a coordenação de ao menos dois registros, podemos concluir que a maioria dos OED examinados contribui pouco para tanto.

Com relação à contextualização e interdisciplinaridade, verificamos que estão presentes, na maioria dos OED, situações - relacionadas não apenas às práticas e necessidades sociais como também à História da Matemática, à ficção, ou às articulações entre conceitos e procedimentos no interior da própria Matemática que permitem aos alunos atribuir significados aos conteúdos matemáticos. Tais situações podem ser, de acordo com o que preconizam Machado (2011) e Spinelli (2011), consideradas contextos significativos. Algumas delas permitem, sobretudo com a intervenção do professor, desencadear propostas interdisciplinares.

De modo geral, é possível concluir que os OED podem contribuir para a construção do conhecimento em Matemática, mas isso depende da intervenção do professor que é, sem dúvida, quem vai propiciar a exploração daquilo que esses recursos têm a oferecer. Para tanto, sua sensibilidade em vislumbrar propostas de trabalho que vão além do que está sendo explicitamente veiculado é imprescindível.

A partir do trabalho realizado, surgem novas perguntas que podem vir a nortear futuros projetos de pesquisa. Exemplificando temos:

- De que forma os OED vem sendo trabalhados pelo professor?

- Os OED têm mudado o modo como o professor utiliza o livro didático? 
- A incorporação desses recursos em sala de aula tem contribuído para a apreensão conceitual dos objetos matemáticos pelo aluno?

A esperança é que esta pesquisa possa não só auxiliar na criação e aperfeiçoamento de futuros OED, como também na conscientização do professor de que é possível tornar o ensino de Matemática mais prazeroso e significativo para os alunos. 


\section{Referências bibliográficas}

BALBINO, R. V. Análise da Coerência Pedagógica entre Livros Didáticos e Objetos de Aprendizagem de Matemática do PNLD 2014. Disponível em:

$<$ http://lematec.net/CDS/XVIIIEBRAPEM/PDFs/GD6/balbino6.pdf >. Acesso em: 01 abr. 2016.

BONGIOVANNI, V. Sobre definições de trapézios isósceles. In: REVISTA DO PROFESSOR DE MATEMÁTICA. n. 72, 2010. p. 9 - 10.

BORBA, M. C. Tecnologias informáticas na Educação Matemática e reorganização do pensamento. In: BICUDO, M. A. V. (org.). Pesquisa em Educação Matemática: concepções e perspectivas. São Paulo: UNESP, 1999. p. 285 - 295.

; PENTEADO, M. G. Informática e Educação Matemática. Belo Horizonte: Autêntica Editora, 2012.

; SILVA, R. S. R.; GADANIDIS G. Fases das tecnologias digitais em

Educação Matemática: Sala de aula e internet em movimento. Belo Horizonte: Autêntica Editora, 2014.

; (orgs.). Educação Matemática: pesquisa em movimento. São Paulo:

Cortez, 2012. p. $287-307$.

BRASIL. Ministério da Educação. Lei de Diretrizes e Bases da Educação Nacional. Lei n. 9.394/96. Disponível em:

< http://www.planalto.gov.br/ccivil 03/leis//9394.htm >. Acesso em: 01 abr. 2016

CARDOSO, A. C. S. Feedback em contextos de ensino-aprendizagem on-line. In: Linguagens e Diálogos. v. 2. n. 2, 2011. p. 17 - 34.

CARVALHO, J. B. P. F.; LIMA, P. Coleção explorando o ensino - Matemática. Brasília: 2010. v. 17. Capítulo 1.

CENSO ESCOLAR DA EDUCAÇÃO BÁSICA 2013: RESUMO TÉCNICO. Disponível em:<http://download.inep.gov.br/educacao basica/censo escolar/resumos tecnicos/ resumo tecnico censo educacao basica 2013.pdf>. Acesso em: 21 set. 2015.

CURY, C. R. J. Livro didático como assistência ao estudante. Revista diálogo educacional, Curitiba, v.09, n. 26, p. 119 - 130, jan./abr.2009. 
D'AMBROSIO, B. S. Formação de professores de Matemática para o século XXI: o grande desafio. In: Pro-Posições, Campinas, mar. 1993, n. 1 (10) p. 35 - 41.

D’AMORE, B. Epistemologia e Didática da Matemática. Tradução de Maria Cristina Bonomi. São Paulo: Escrituras Editora, 2005.

DAMM, R. F. Registros de representação. In: MACHADO, S. D. A. (org.). Educação Matemática: uma introdução. São Paulo: EDUC, 1999.

DANTE, L. R. Livro didático de matemática: uso ou abuso?. Em aberto, Brasília, ano 16, n. 69, p. 83 - 90, jan./mar. 1996.

DUVAL, R. Semiósis do Pensamento Humano: Registros semióticos e aprendizagens intelectuais. São Paulo: Editora Livraria da Física, 2009.

FILGUEIRAS, J. M. Os processos de avaliação do livro didático no Brasil: 1938 1984. 2011. 263 f. Tese (Doutorado em Educação: história, política, sociedade) Pontifícia Universidade Católica, São Paulo. 2011.

FREIRE, P. Pedagogia do oprimido. Rio de Janeiro: Paz e Terra, 1987.

Pedagogia da autonomia: saberes necessários à prática docente. Rio de Janeiro: Paz e Terra, 2014.

FUNDO NACIONAL DE DESENVOLVIMENTO DA EDUCAÇÃO - FNDE. Livro didático. Histórico. Disponível em:

<http://www.fnde.gov.br/programas/livro-didatico/livro-didatico-historico>. Acesso em: 01 abr. 2016

FUNDO NACIONAL DE DESENVOLVIMENTO DA EDUCAÇÃO - FNDE. Programa Nacional de Tecnologia Educacional - Prolnfo. Disponível em:

$<$ https://www.fnde.gov.br/fndelegis/action/ActionDatalegis.php?cod menu=375\&cod $\underline{\text { modulo }=21 \& \text { acao }=\text { abrirTreeview }}>$. Acesso em: 01 abr. 2016

GITIRANA, V.; BITTAR, M.; IGNÁCIO, R. Objetos Educacionais Digitais: Políticas e Perspectivas. In: II FÓRUM GT 6 - SBEM. x. 2, 2014. Educação Matemática: Novas Tecnologias e Educação a Distância.

GOLDSTEIN, Rebecca. Incompletude: a prova e o paradoxo de Kurt Gödel. Tradução de Ivo Korytowski. São Paulo: Compahia das Letras, 2008. 
JANEGITZ, L. E. Indícios da existência do coletivo seres-humanos-com-lousadigital e a produção de conhecimento matemático. 2014. 141 f. Dissertação (Mestrado em Educação em Ciências e em Matemática) - Universidade Federal do Paraná, Curitiba, Paraná. 2014.

JAPIASSÚ, H. Interdisciplinaridade e Patologia do saber. Rio de Janeiro: Imago, 1976.

LÉVY, P. As tecnologias da inteligência: o futuro do pensamento na era da informática. Tradução de Carlos Irineu da Costa. Rio de Janeiro: Editora 34,1993.

. A Máquina Universo: criação, cognição e cultura informática. Tradução de Bruno Charles Magne. Porto Alegre: Artmed, 1998.

MACHADO, N. J. Educação: projetos e valores. São Paulo: Escrituras Editora, 2006.

Epistemologia e Didática: as concepções de conhecimento e inteligência e a prática docente. São Paulo: Cortez, 2011.

. Mil e uma \#191 Os factos e os fictos, 2013b. Disponível em: < http://www.nilsonjosemachado.net/mil-e-uma-191-os-factos-e-os-fictos/ >. Acesso em: 01 abr. 2016

. Mil e uma \#227 Tecnologias: fascínio x fastio, 2013a. Disponível em: < http://www.nilsonjosemachado.net/mil-e-uma-227-tecnologias-fascinio-x-fastio/ >. Acesso em: 01 abr. 2016

Mil e uma \#372 O papel do Livro Didático, 2015. Disponível em: $<$ http://www.nilsonjosemachado.net/mil-e-uma-372-o-papel-do-livro-didatico/ >. Acesso em: 01 abr. 2016 Sobre livros didáticos, quatro pontos. Em aberto, Brasília, ano 16, n. 69 , p. $30-38$, jan./mar. 1996.

MALTEMPI, M. V. Construcionismo: pano de fundo para pesquisas em informática aplicada à Educação Matemática. In: BICUDO, M. A. V.

MORAES, M. C. Informática educativa no Brasil: uma história vivida, algumas lições aprendidas. Revista Brasileira de Informática na Educação, São Paulo, n. 1, p. 1 35, abr.1997. 
MORIN, E. Os Sete Saberes necessários à Educação do Futuro. São Paulo: Cortez, 2000.

. Educação e complexidade: os sete saberes e outros ensaios. São Paulo: Cortez, 2005.

PAPERT, S. A máquina das crianças: repensando a Escola na Era da Informática. Tradução de Sandra Costa. Porto Alegre: Artes Médicas, 1994.

A família em rede: ultrapassando a barreira digital entre gerações. Lisboa: Relógio D’Água Editores, 1997.

PASSOS, J. E. Metodologia para o design de interface de ambiente virtual centrado no usuário. 2010. 188 f. Dissertação (Mestrado) - Escola de Engenharia e Faculdade de Arquitetura. Universidade Federal do Rio Grande do Sul, Porto Alegre. 2010.

PREVEDELLO, C. F. Design de interação e motivação nos projetos de interface para objetos de aprendizagem para EaD. 2011. 136 f. Dissertação (Mestrado) Escola de Engenharia e Faculdade de Arquitetura. Programa de Pós-Graduação em Design, Universidade Federal do Rio Grande do Sul, Porto Alegre. 2011.

REATEGUI, E.; BOFF, E.; FINCO, M. D. Proposta de Diretrizes para Avaliação de Objetos de Aprendizagem: considerando aspectos pedagógicos e técnicos. In Revista novas tecnologias na Educação. PPGIE/UFRGS, v. 8. n. 3, dez. 2010.

SERRES, M. Disponível em: < http://www.rodaviva.fapesp.br/materia/386/entre >. Acesso em: 01 abr. 2016

SILVA, D. R. Livro didático de Matemática: lugar histórico e perspectivas. 2010. 152 f. Dissertação (Mestrado em Ensino de Ciências e Matemática) - Faculdade de Educação, Universidade de São Paulo, São Paulo. 2010.

SPINELLI, W. A construção do conhecimento entre o abstrair e o contextualizar: o caso do ensino de Matemática. 2011. 138 f. Tese (Doutorado) - Faculdade de Educação, Universidade de São Paulo, São Paulo, 2011.

VALENTE, J. A. (org.) Computadores e conhecimento: repensando a educação. Campinas Gráfica Central da UNICAMP, p. 24 - 44. cap. 2.1993 
- (org.) Computadores na Sociedade do Conhecimento.

Campinas, SP: UNICAMP/NIED, p. 89 - 110. 1999a

. Informática na Educação: Uso de software educacional X Uso de software aberto. Campinas, SP: UNICAMP/NIED. 1999b

\section{Referências dos OED consultados}

- Os OED de 5.1 a 5.8 encontram-se disponíveis em:

$<$ http://www.ftd.com.br/pnldef2 2014/index.php?page=colection\&dis=matematica\&co l=6\&oed=1\#target $>$ Acesso em: 01 abr. 2016

Referência da coleção.

SOUZA, J; Patare, P. M. Vontade de saber Matemática - 60 ao 9a ano. São Paulo: FTD, 2012.

- Os OED de 5.9 a 5.13 encontram-se disponíveis em:

$<$ http://www.modernadigital.com.br/main.jsp?lumPageld=4028818B3D747D6E013D8 99088E25C83\&ldColeca0 =8A8A8A833D8C9B1C013DA83D70A34B9B $>$. Acesso em: 01 abr. 2016

Referência da coleção.

OBRA COLETIVA. Projeto Araribá - 6a ao 9a ano. São Paulo: Moderna, 2012. 